\title{
Field Evaluation of
} Advances in EnergyEfficiency Practices for Manufactured Homes

E. Levy, J. Dentz, E. Ansanelli, G. Barker, P. Rath, and D. Dadia ARIES Collaborative 


\section{NOTICE}

This report was prepared as an account of work sponsored by an agency of the United States government. Neither the United States government nor any agency thereof, nor any of their employees, subcontractors, or affiliated partners makes any warranty, express or implied, or assumes any legal liability or responsibility for the accuracy, completeness, or usefulness of any information, apparatus, product, or process disclosed, or represents that its use would not infringe privately owned rights. Reference herein to any specific commercial product, process, or service by trade name, trademark, manufacturer, or otherwise does not necessarily constitute or imply its endorsement, recommendation, or favoring by the United States government or any agency thereof. The views and opinions of authors expressed herein do not necessarily state or reflect those of the United States government or any agency thereof.

Available electronically at SciTech Connect http:/www.osti.gov/scitech

Available for a processing fee to U.S. Department of Energy

and its contractors, in paper, from:

U.S. Department of Energy

Office of Scientific and Technical Information

P.O. Box 62

Oak Ridge, TN 37831-0062

OSTI http://www.osti.gov

Phone: 865.576.8401

Fax: 865.576.5728

Email: reports@osti.gov

Available for sale to the public, in paper, from:

U.S. Department of Commerce

National Technical Information Service

5301 Shawnee Road

Alexandria, VA 22312

NTIS http://www.ntis.gov

Phone: 800.553 .6847 or 703.605 .6000

Fax: 703.605.6900

Email: orders@ntis.gov 


\title{
Field Evaluation of Advances in Energy-Efficiency Practices for Manufactured Homes
}

\author{
Prepared for: \\ The National Renewable Energy Laboratory \\ On behalf of the U.S. Department of Energy's Building America Program \\ Office of Energy Efficiency and Renewable Energy \\ 15013 Denver West Parkway \\ Golden, CO 80401 \\ NREL Contract No. DE-AC36-08GO28308 \\ Prepared by: \\ E. Levy, J. Dentz, E. Ansanelli, G. Barker, P. Rath, and D. Dadia \\ Advanced Residential Integrated Energy Solutions (ARIES) Collaborative \\ 1776 Broadway Suite 2205 \\ New York, NY 10019 \\ NREL Technical Monitor: Stacey Rothgeb \\ Prepared under Subcontract No. KNDJ-0-40347-05
}

March 2016 
The work presented in this report does not represent performance of any product relative to regulated minimum efficiency requirements.

The laboratory and/or field sites used for this work are not certified rating test facilities. The conditions and methods under which products were characterized for this work differ from standard rating conditions, as described.

Because the methods and conditions differ, the reported results are not comparable to rated product performance and should only be used to estimate performance under the measured conditions. 


\section{Contents}

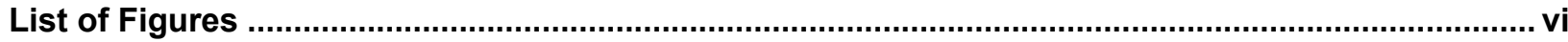

List of Tables

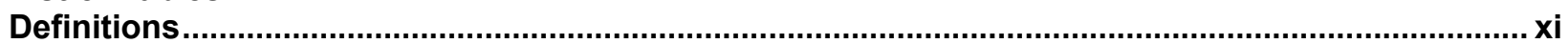

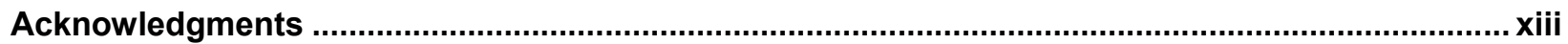

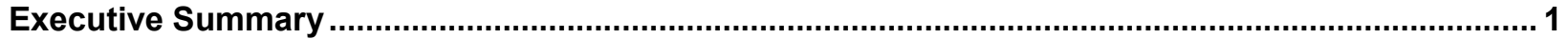

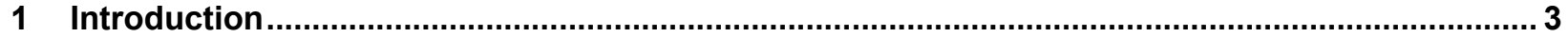

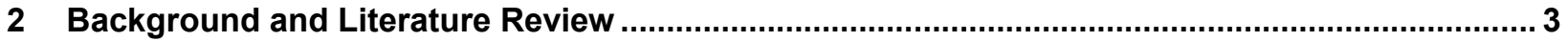

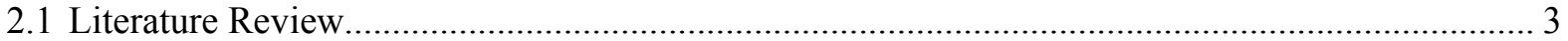

2.2 Research Gaps and Relevance to Building America's Goals ................................................. 7

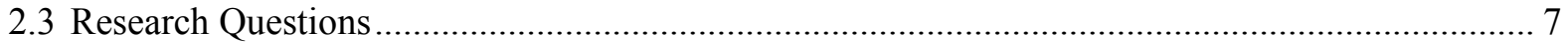

3 Whole-Building Performance Assessment

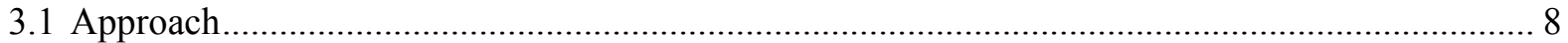

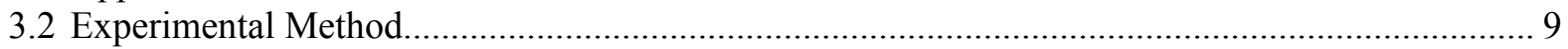

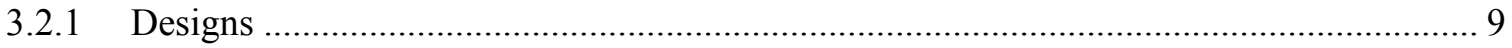

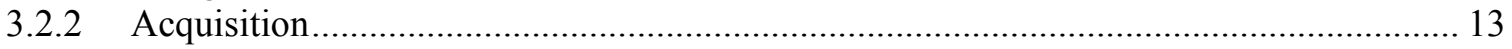

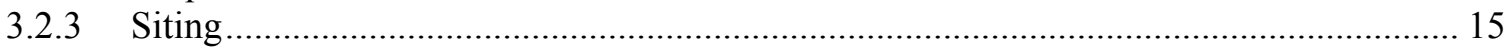

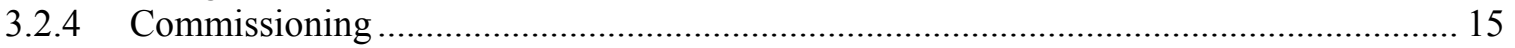

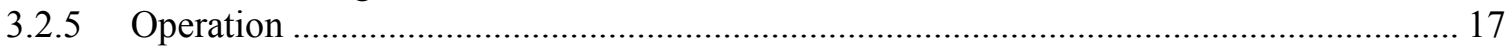

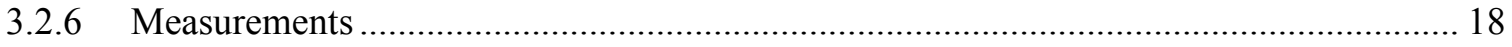

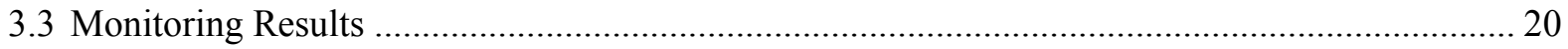

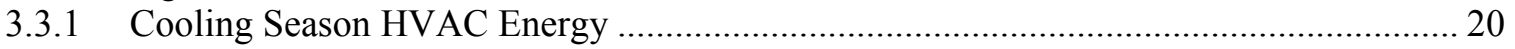

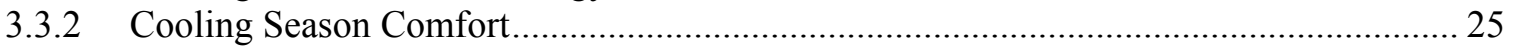

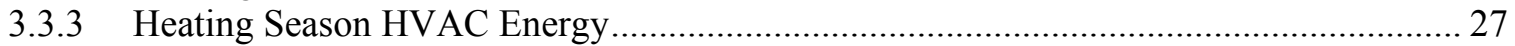

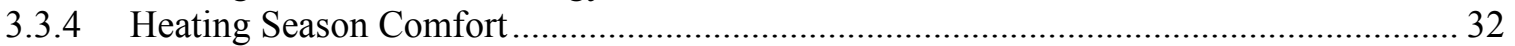

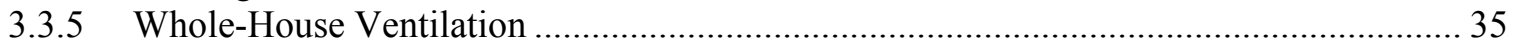

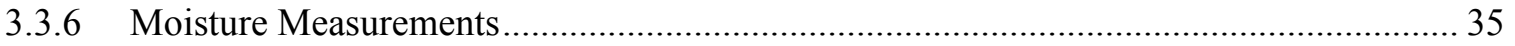

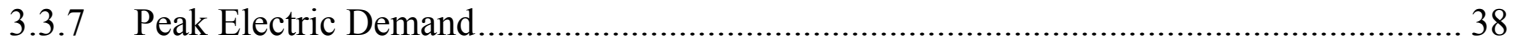

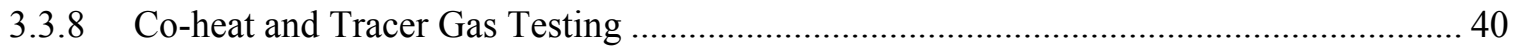

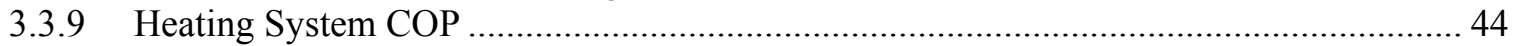

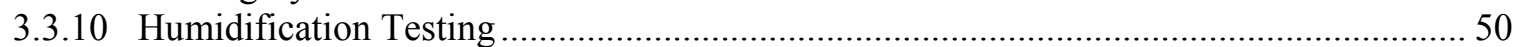

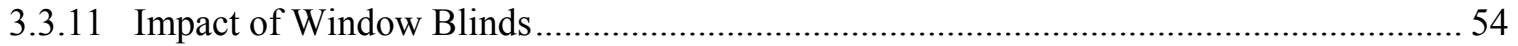

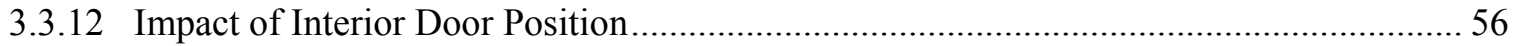

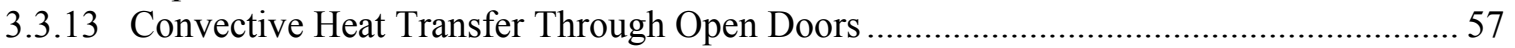

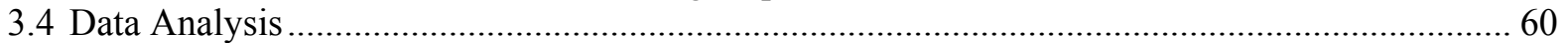

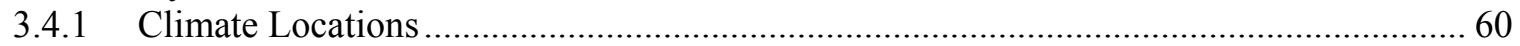

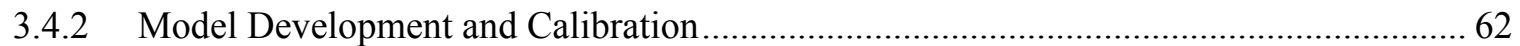

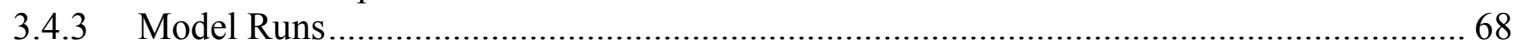

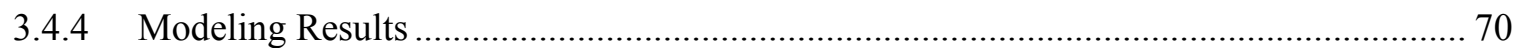

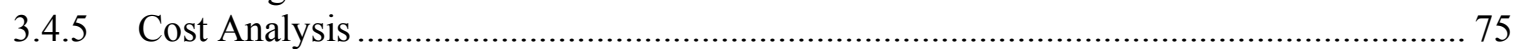

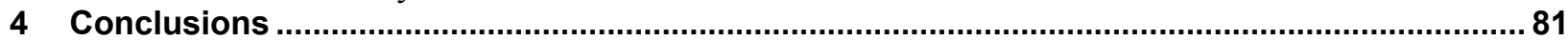

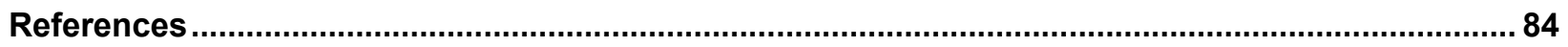

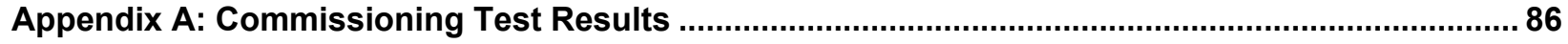

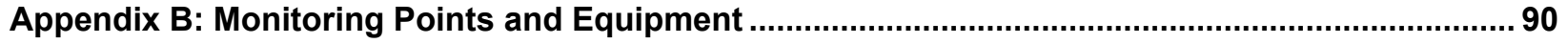

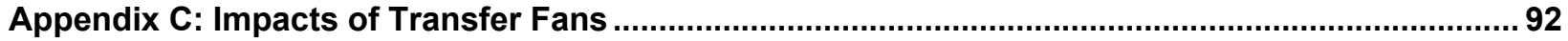

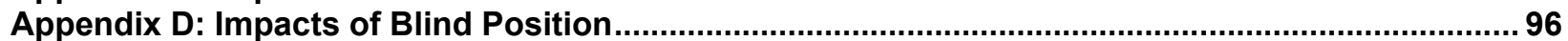

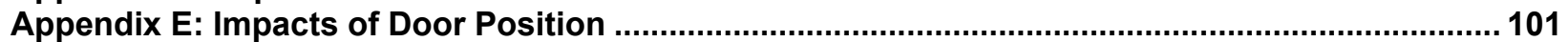

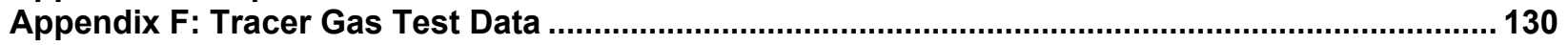

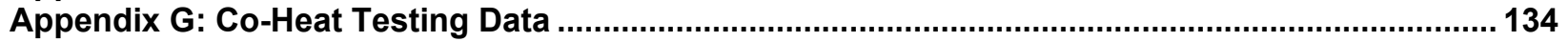

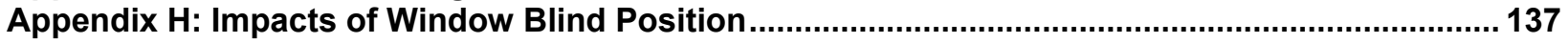




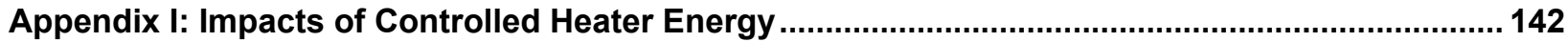

Appendix J: Construction Drawings. 


\section{List of Figures}

Figure 1. Floor plan

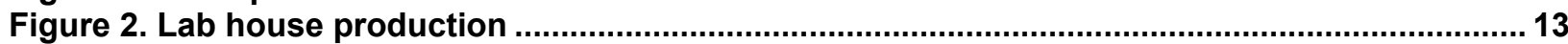

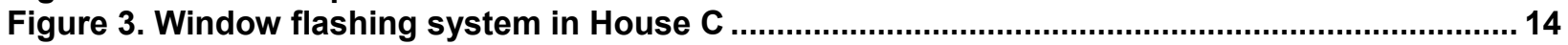

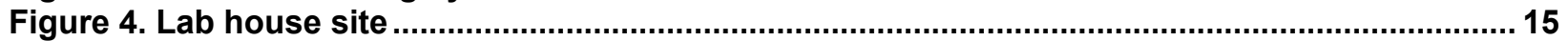

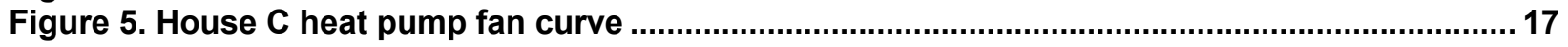

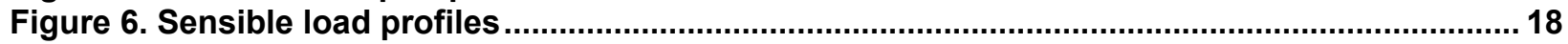

Figure 7. Cooling power relative to outdoor temperature for all three houses (Aug. 29-Sept. 15,

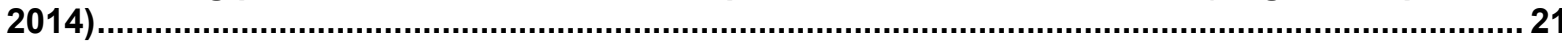

Figure 8. House A cooling energy consumption at various outdoor temperatures (Aug. 29-Sept.

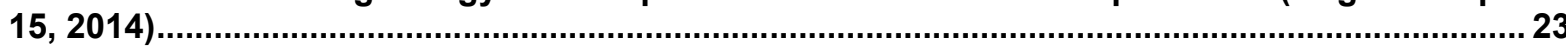

Figure 9. House B cooling energy consumption at various outdoor temperatures (Aug. 29-Sept. $15,2014)$

Figure 10. House C cooling energy consumption at various outdoor temperatures (Aug. 29-Sept. 15, 2014). 24

Figure 11. House A room and outdoor temperatures during the typical cooling season (Aug. 29-

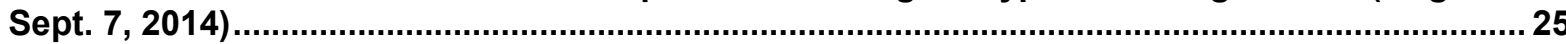

Figure 12. House B room and outdoor temperatures during the typical cooling season (Aug. 29-

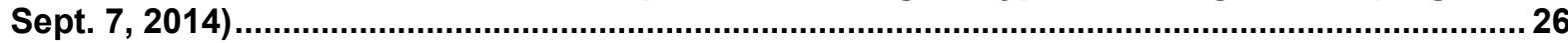

Figure 13. House $\mathrm{C}$ room and outdoor temperatures during the typical cooling season (Aug. 29-

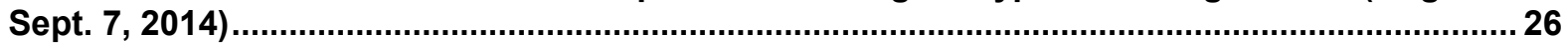

Figure 14. Heating power compared to outdoor temperature for all three houses (Jan. 6-13, 2015)

Figure 15. House B backup electric resistance heating energy compared to outdoor air temperature

Figure 16. House $C$ heat pump, transfer fan, and resistance heating energy compared to ambient

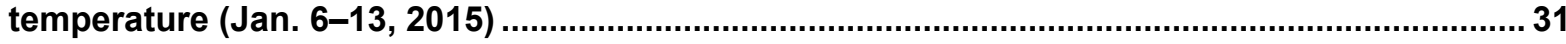

Figure 17. House $C$ resistance heating energy compared to ambient temperature (Jan. 6-13, 2015)

Figure 18. House $\mathrm{C}$ room and outdoor temperatures for the initial heating season analysis (Nov. 12-17, 2014).

Figure 19. House C room and outdoor temperatures with resistance heat in remote rooms (Jan. 613, 2015)

Figure 20. House A room and outdoor temperatures (Jan. 6-13, 2015).......................................... 34

Figure 21. House $B$ room and outdoor temperatures (Jan. 6-13, 2015)....................................... 34

Figure 22. Moisture content and temperature/relative humidity sensors mounted in wall cavity ... 36 Figure 23. House B wall cavity conditions and wood moisture content (April 2014-April 2015)..... 37 Figure 24. House $C$ wall cavity conditions and wood moisture content (April 2014-April 2015)..... 37 Figure 25. Monthly peak demand during coincident peak hours of the Tennessee Valley Authority system

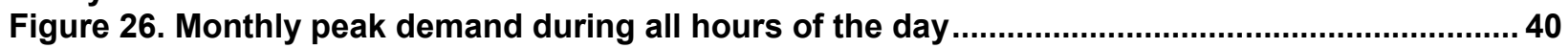

Figure 27. Tracer gas sampling equipment and sampling tube ........................................................ 42

Figure 28. House $B$ refrigerant coil in heating mode showing nonuniform temperatures ................47

Figure 29. Air handling unit fan power for auto- and high-speed settings .......................................48

Figure 30. Fan curve based on onetime flow and power measurements ........................................ 48

Figure 31. Comparison of mini-split COP (co-heat measurement method) with auto and high fan speeds

Figure 32. Comparison of mini-split COP (air-side measurement method) with low and high fan speeds

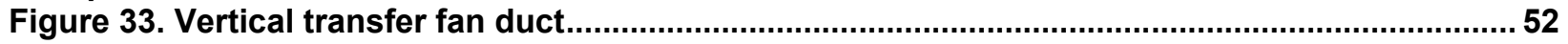

Figure 34. High, low, and primary room temperature sensors................................................... 53

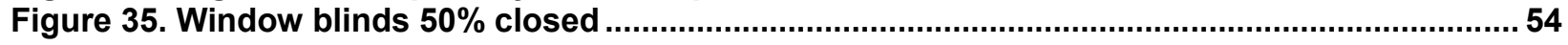

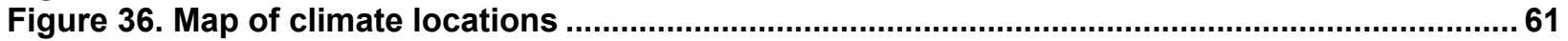

Figure 37. Annual energy consumption comparison-Columbus, Mississippi ............................... 70 
Figure 38. Annual space-conditioning comparison-Columbus, Mississippi ................................. 71

Figure 39. Annual energy consumption comparison-Knoxville, Tennessee .................................. 72

Figure 40. Annual space-conditioning comparison-Knoxville, Tennessee .....................................73

Figure 41. Annual energy consumption comparison-Bowling Green, Kentucky ........................... 74

Figure 42. Annual space-conditioning comparison-Bowling Green, Kentucky .............................. 75

Figure 43. House $C$ Bedroom 2 temperatures with and without transfer fan operation (cooling season)

Figure 44. House C Bedroom 3 temperatures with and without transfer fan operation (cooling season) .

Figure 45. House $\mathrm{C}$ living room temperatures with and without transfer fan operation (cooling season)

Figure 46. House $\mathrm{C}$ master bedroom temperatures with and without transfer fan operation (cooling season)

Figure 47. House $\mathrm{C}$ master bathroom temperatures with and without transfer fan operation (cooling season).

Figure 48. House $C$ impacts of blind position in Bedroom 2 on room temperature compared to outdoor temperature (cooling season)

Figure 49. House C impacts of blind position on Bedroom 3 on room temperature compared to outdoor temperature (cooling season).

Figure 50. House C impacts of blind position on living room temperature compared to outdoor

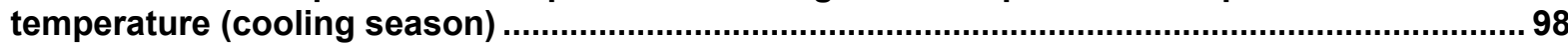

Figure 51. House $\mathrm{C}$ impacts of blind position on master bedroom temperature compared to outdoor temperature (cooling season)

Figure 52. House $C$ impacts of blind position on master bathroom temperature compared to outdoor temperature (cooling season)

Figure 53. House A impacts of door position on Bedroom 2 temperature compared to outdoor temperature $\left(0.8 \mathrm{cfm} / \mathrm{ft}^{2}\right)$ (cooling season).

Figure 54. House A impacts of door position on Bedroom 3 temperature compared to outdoor temperature $\left(1 \mathrm{cfm} / \mathrm{ft}^{2}\right)$ (cooling season).

Figure 55. House A impacts of door position on living room temperature compared to outdoor temperature (cooling season).

Figure 56. House A impacts of door position on master bedroom temperature compared to outdoor temperature $\left(0.5 \mathrm{cfm} / \mathrm{ft}^{2}\right)$ (cooling season).

Figure 57. House A impacts of door position on master bathroom temperature compared to outdoor temperature $\left(1.2 \mathrm{cfm} / \mathrm{ft}^{2}\right.$ ) (cooling season) ............................................................... 105

Figure 58. House B impacts of door position on Bedroom 2 room temperature compared to outdoor temperature $\left(0.7 \mathrm{cfm} / \mathrm{ft}^{2}\right)$ (cooling season) .................................................................. 106

Figure 59. House B impacts of door position on Bedroom 3 room temperature compared to outdoor temperature $\left(0.8 \mathrm{cfm} / \mathrm{ft}^{2}\right)$ (cooling season)

Figure 60. House B impacts of door position on living room temperature compared to outdoor temperature-aspirator failture open period (cooling season) ................................................. 108

Figure 61. House B impacts of door position on master bedroom temperature compared to outdoor temperature $\left(0.5 \mathrm{cfm} / \mathrm{ft}^{2}\right)$ (cooling season).

Figure 62. House B impacts of door position on master bathroom temperature compared to outdoor temperature $\left(1.2 \mathrm{cfm} / \mathrm{ft}^{2}\right)$ (cooling season).

Figure 63. House $\mathrm{C}$ impacts of door position on Bedroom 2 room temperature compared to outdoor temperature (cooling season) …........................................................................... 111

Figure 64. House $C$ impacts of door position on Bedroom 3 room temperature compared to outdoor temperature (cooling season)...

Figure 65. House $\mathrm{C}$ impacts of door position on living room temperature compared to outdoor temperature (cooling season)....

igure 66. House $\mathrm{C}$ impacts of door position on master bedroom temperature compared to outdoor temperature (cooling season)

igure 67. House $C$ impacts of door position on master bathroom temperature compared to outdoor temperature (cooling season) 
Figure 68. House A impacts of door position on Bedroom 2 temperature compared to outdoor temperature (heating season)

Figure 69. House A impacts of door position on Bedroom 3 temperature compared to outdoor temperature (heating season)

Figure 70. House A impacts of door position on living room temperature compared to outdoor temperature (heating season).

Figure 71. House A impacts of door position on master bedrdoom temperature compared to outdoor temperature (heating season)

Figure 72. House A impacts of door position on master bathroom temperature compared to outdoor temperature (heating season)

Figure 73. House B impacts of door position on Bedroom 2 temperature compared to outdoor temperature (heating season).

Figure 74. House B impacts of door position on Bedroom 3 temperature compared to outdoor temperature (heating season)

Figure 75. House B impacts of door position on living room temperature compared to outdoor temperature (heating season)....

Figure 76. House B impacts of door position on master bedroom temperature compared to outdoor temperature (heating season)

Figure 77. House B impacts of door position on master bathroom temperature compared to outdoor temperature (heating season)

Figure 78. House $\mathrm{C}$ impacts of door position on Bedroom 2 temperature compared to outdoor temperature (heating season).

Figure 79. House C impacts of door position on Bedroom 3 temperature compared to outdoor temperature (heating season).

Figure 80. House $\mathbf{C}$ impacts of door position on living room temperature compared to outdoor temperature (heating season).

Figure 81. House $C$ impacts of door position on master bedroom temperature compared to outdoor temperature (heating season)

Figure 82. House $\mathrm{C}$ impacts of door position on master bathroom temperature compared to outdoor temperature (heating season)

Figure 83. House C Bedroom 2 impacts of controlled heater energy ............................................ 142

Figure 84. House $C$ Bedroom 3 of controlled heater energy .......................................................... 143

Figure 85. House $C$ master bedroom impacts of controlled heater energy .................................... 144

Figure 86. House $C$ master bathroom impacts of controlled heater energy ................................... 144

Figure 87. House A production print (House B is identical.) .......................................................... 145

Figure 88. House $C$ mechanical system schematic plan ......................................................... 146

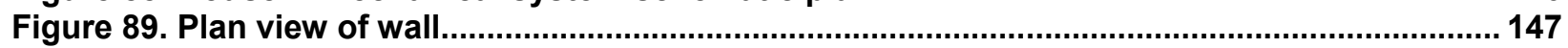

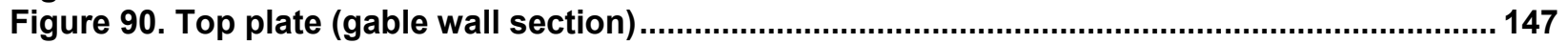

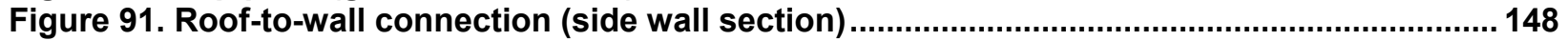

Figure 92. Floor-to-wall connection (side wall section) ….......................................................... 148

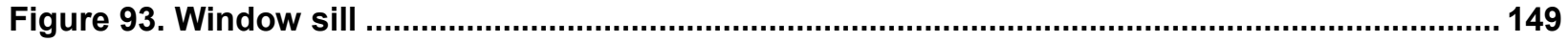

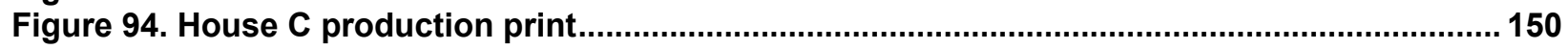




\section{List of Tables}

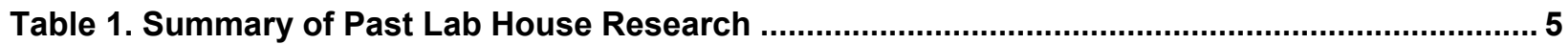

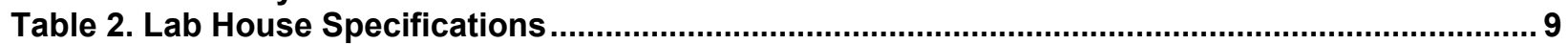

Table 3. Cooling and Heating Equipment Specifications ............................................................. 11

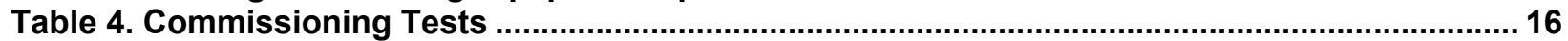

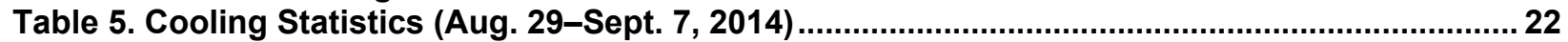

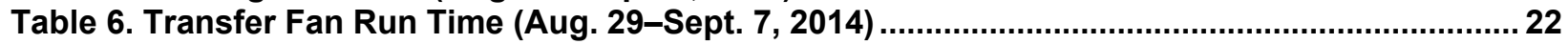

Table 7. Cooling Energy Consumption (Aug. 29-Sept. 15, 2014) ............................................... 23

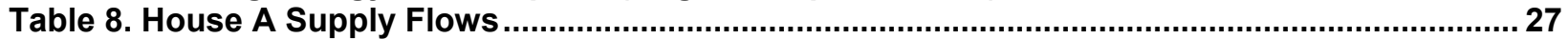

Table 9. Heating Statistics (Average Ambient Temperature of $41.3^{\circ} \mathrm{F}$ ) (Nov. 12-17, 2014) .............. 27

Table 10. Heating Statistics with Resistance Heat in House C Remote Rooms (Average Ambient

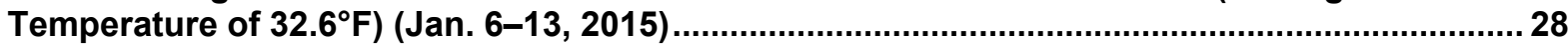

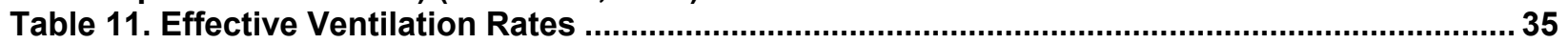

Table 12. Wall Cavity Maximum, Minimum, and Average Conditions (April 2014-April 2015) ......... 38

Table 13. Summary of Average Peak Demand Reduction During Peak Hours of the Tennessee

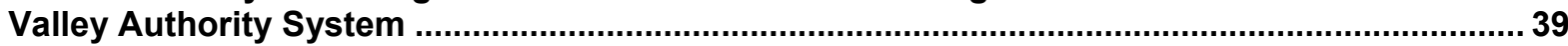

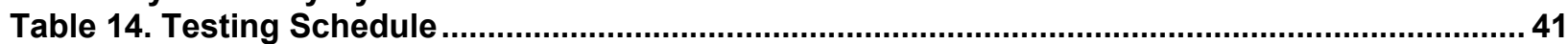

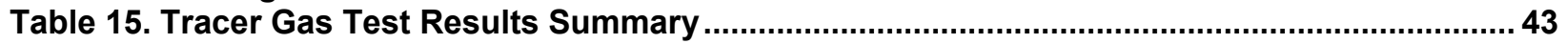

Table 16. Tracer Gas Test Results Summary-With Systems Operating .......................................43

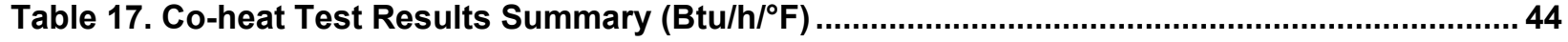

Table 18. Co-Heat Test Results Summary Adjusted for Infiltration ................................................... 44

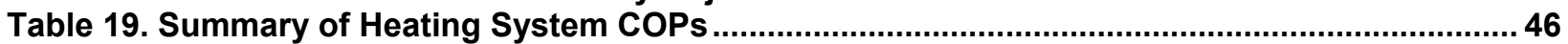

Table 20. Mini-Split Heat Pump COPs at High and Low Fan Speeds ............................................... 49

Table 21. Humidification Test Results ..................................................................................... 51

Table 22. Analysis Period for the Impact of Transfer Fans on Room Temperatures in House C..... 51

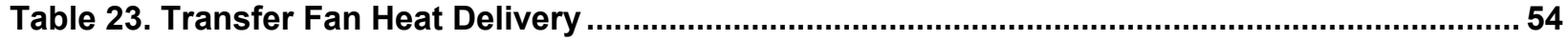

Table 24. Window Blinds Analysis Period Conditions ................................................................5

Table 25. Cooling Energy Reduction Due to Window Blinds ........................................................... 56

Table 26. Interior Door Position Analysis Periods ...................................................................... 56

Table 27. Convective Heat Flow Through Open Doors ................................................................. 57

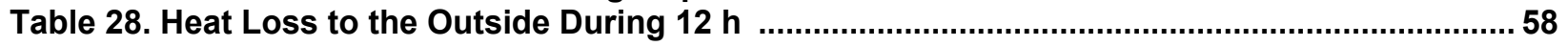

Table 29. Heat Transfer into Rooms During $12 \mathrm{~h}$ : Calculations ...................................................... 58

Table 30. Convective Heat Transfer Through Open Doors: Calculations ........................................60

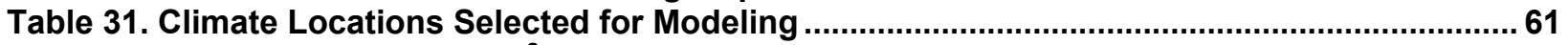

Table 32. Model Calibration Error ${ }^{\mathrm{a}}$ in Space-Conditioning Energy...................................................62

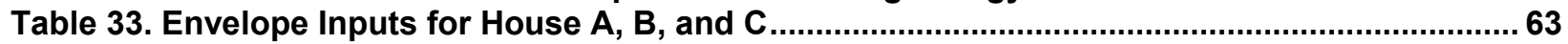

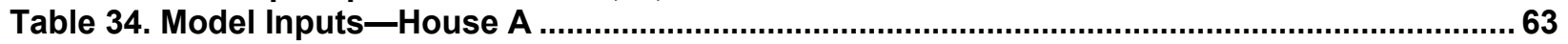

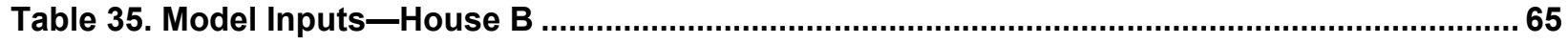

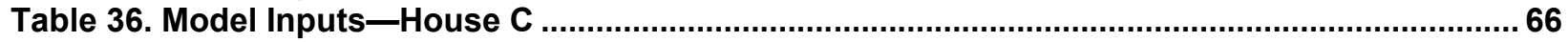

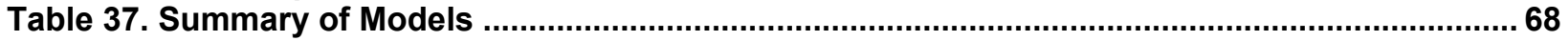

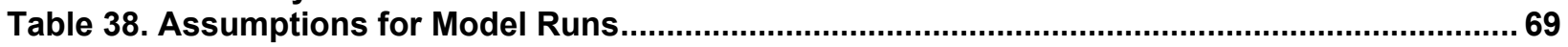

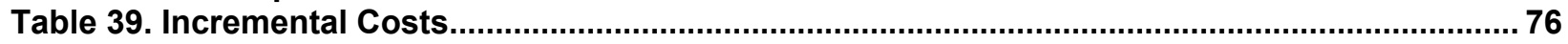

Table 40. Energy Savings and Payback_Columbus, Mississippi..................................................79

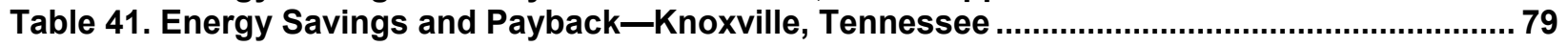

Table 42. Energy Savings and Payback—Bowling Green, Kentucky ............................................... 80

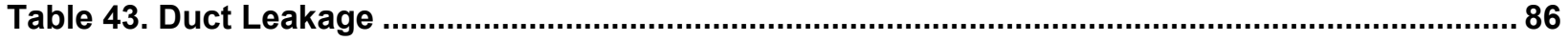

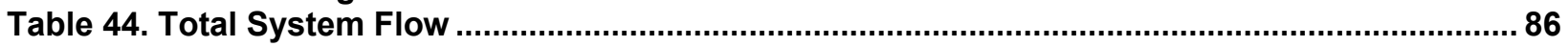

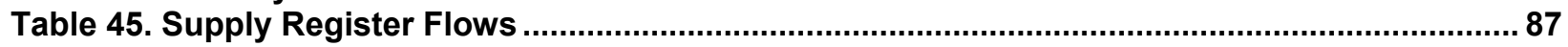

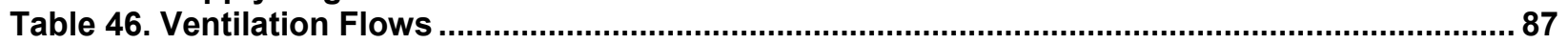

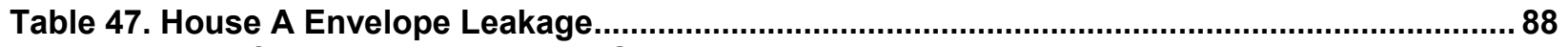

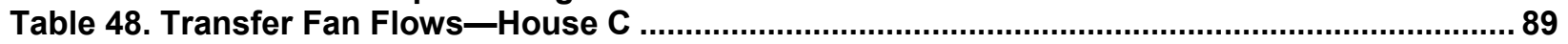

Table 49. Inventory of Monitoring Equipment, Data Loggers, and Sensors .................................. 90

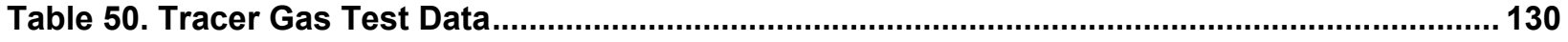

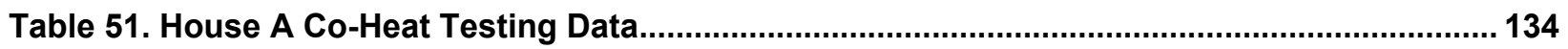


Table 52. House B Co-Heat Testing Data

Table 53. House C Co-Heat Testing Data...

Table 54. Data Used for Multi-Variable Regression-Blinds Closed Period (Sept. 23-29)

137

Table 55. Predicted Cooling Energy Calculation with Normalized Data-Blinds Open Period (Aug. 17-23)... 137

Table 56. Window Blinds Regression 138 


\section{Definitions}

${ }^{\circ} \mathrm{F}$

$\mathrm{AC}$

ACH50

AIM-2

ARIES

ASHRAE

Avg.

BEopt V 2.3.0.2

Btu

$\mathrm{CFH}$

$\mathrm{cfm}$

COP

d

DHW

DOE

EER

$\mathrm{EF}$

$\mathrm{ft}^{2}$

$\mathrm{h}$

HSPF

HUD

HVAC

IECC

kBtu

$\mathrm{kg}$

$\mathrm{kJ}$

$\mathrm{kPa}$

$\mathrm{kW}$

$\mathrm{kWh}$

MEF
Degree Fahrenheit

Air conditioner

Air change per hour at 50 Pascals

The Alberta Air Infiltration Model

Advanced Residential Integrated Energy Solutions Collaborative

American Society of Heating, Refrigerating, and Air-Conditioning Engineers

Average (tables only)

Building Energy Optimization version 2.3.0.3

British thermal unit

Cubic feet per hour

Cubic feet per minute

Coefficient of performance

Day

Domestic hot water

U.S. Department of Energy

Energy efficiency ratio

Energy factor

Square feet

Hour

Heating seasonal performance factor

U.S. Department of Housing and Urban Development

Heating, ventilating, and air conditioning

International Energy Conservation Code

One Kilo British thermal unit

Kilogram

Kilojoule

Kilopascal

Kilowatt

Kilowatt-hour

Modified Energy Factor 
$\min$

MMBtu

N/A

$\mathrm{S}$

SEER

SHGC

Temp.

UA value

U-value

W

$\mathrm{yr}$

ZEMH

ZERH
Minute

One million British thermal units

Not applicable

Second

Seasonal Energy Efficiency Ratio

Solar heat gain coefficient

Temperature (tables only)

Heat loss over the entire surface area

Overall heat transfer coefficient

Watt

Year

Zero Energy Manufactured Home

Zero Energy Ready Home 


\section{Acknowledgments}

The Advanced Residential Integrated Energy Solutions Collaborative (ARIES) would like to thank those who contributed to this effort, including the following:

Lisa Haislip of the Tennessee Valley Authority and Bert Kessler from the Systems Building Research Alliance represented the project sponsors, the organizations committed to helping the manufactured-homebuilding industry find cost-effective ways to reduce energy use.

Stacey Rothgeb, Michael Gestwick, Lieko Earle, Jon Winkler, and Chuck Booten from the National Renewable Energy Laboratory provided invaluable technical guidance and project oversight.

A committee comprised of industry representatives provided ideas for and feedback on approaches to developing advanced building techniques that had both commercial and energy savings potential. The group included Bert Kessler of Palm Harbor Homes, Robert Garcia of Fleetwood Homes, Mark Ezzo of Clayton Homes, Manuel Santana of Cavco, Jeff Legault of Skyline Homes, and Rob Luter of Kinro.

The project team thanks the many people from the Clayton family of companies that built, hosted, and assisted with the monitoring and maintenance of the test units, including David Brewer, Terry Owens, Brandon Frazier, Tommy Mehger, and Jim Bauer of SEhomes; Gavin Mabe of Clayton Homes; and Mike Wade of Cavalier Homes.

The following staff from product suppliers provided timely technical support and donated materials and products for the tests: Francis Babineau of Johns Manville, Brian Lieburn and Brian Mallon from the Dow Chemical Company, Joe Cefaly and Mike Bush from Mitsubishi Electric US, Tom Tjernlund and Tim Hoyez from Tjernlund Fans, Fred Irvin from AccuVent, Craig Marden from Owens Corning, Mark Tackett from LP Corporation, Steve Richards from NORDYNE, and Tom Tracey and Terry Dullaghan from SENCO Brands, Inc.

The ARIES team was also assisted by engineer Kapil Varshney, who provided timely and valuable support. 


\section{Executive Summary}

Through field-testing and analysis, this project evaluated whole-building approaches and estimated the relative contributions of select technologies toward reducing energy use related to space conditioning in new manufactured homes. Three lab houses of varying designs were built and tested side-by-side under controlled conditions in Russellville, Alabama. The tests provided a valuable indicator of how changes in the construction of manufactured homes can contribute to significant reductions in energy use.

The three side-by-side, unoccupied lab houses included heating, ventilating, and air-conditioning systems that simulated sensible loads. Each house represented a commonly specified set of features that impacts the energy used for space heating and cooling. The three homes had features that reflected the following levels of energy efficiency: a design meeting best-practice codes according to the U.S. Department of Housing and Urban Development (House A); a manufactured home conforming to typical ENERGY STAR ${ }^{\circledR}$ ratings (House B); and a design meeting the U.S. Department of Energy Zero Energy Ready Home criteria (House C). ${ }^{1}$ Except for the differences in the energy-related measures, the prototypes were identical (floor plan, orientation, construction). (See Table 2 for specifications.) The side-by-side tests provided a wealth of comparative data that yielded the following observations:

- Energy consumption. During the cooling period, House $\mathrm{C}$ used half the energy of the other houses. House B used slightly less energy than House A for cooling. House B and House C consumed about the same amount of heating energy, which was nearly one-third of the heating energy consumed by House A.

- Comfort. All three homes operated within indoor comfort guidelines specified by the Air Conditioning Contractors of America $\left( \pm 3^{\circ} \mathrm{F}\right.$ temperature variation from the temperature at the thermostat during the cooling period) when the interior doors were open. House $\mathrm{C}$ used one-third of the heating energy of House A with superior comfort results. Some bedrooms in House A and House B had difficulty maintaining temperatures within $\pm 2^{\circ} \mathrm{F}$ of the set point.

- Propensity for moisture problems. Wall cavity wood moisture content was slightly higher in House $\mathrm{C}$ than in House B, but it was still well within the safe limits. This was because of the addition of exterior foam insulation to the walls in House C. (The expanded polystyrene foam insulation reduces the overall vapor permeability of the walls.) However, compared to House $\mathrm{B}$, the use of foam sheathing on House $\mathrm{C}$ also resulted in an average higher temperature $\left(5.5^{\circ} \mathrm{F}\right)$ on the interior face of the foam during the heating season, mitigating condensation risk. Note that latent loads were not simulated.

- Peak load performance. ${ }^{2}$ Peak demand in House $\mathrm{C}$ was significantly lower than it was in the other two houses throughout the year. House B had somewhat lower peaks than did House A during most months. House A and House B winter peaks were similar during the winter months, suggesting that House B's peak occurred when the heat pump was not operating and the house was relying solely on electric resistance backup. On average, during

\footnotetext{
${ }^{1}$ House $\mathrm{C}$ was the first manufactured home in the United States to qualify for Zero Energy Ready Home designation.

${ }^{2}$ Comments regarding peak load refer only to the demand resulting from the operation of the space-conditioning and ventilation equipment.
} 
peak hours for the Tennessee Valley Authority system, House B had an 18\% lower peak demand than House A, and House $\mathrm{C}$ had a 69\% lower peak demand than House A.

- Real-world performance of heat pumps. The heating coefficient of performance (COP) was calculated for both heat pumps using two independent methods: (1) airflow and temperature measurements and (2) co-heat testing measurements. ${ }^{3}$ The co-heat testing method was deemed more reliable. Using this method, the COP of both the traditional splitsystem heat pump and the ductless mini-split averaged approximately 2.5 . This was well below what would be expected for the mini-split based on manufacturer data. However, when the mini-split air handling unit fan was forced to run on high speed, its COP increased to 4.11 , indicating that low airflow could have been a cause of poor heat pump performance with this unit. ${ }^{4}$

- Estimate of costs and benefits. The cost premiums to the manufacturer (counting only the energy-efficiency measures) to build House C compared to House A and House B were $\$ 2,060$ and $\$ 1,166$, respectively. The price premiums for the homebuyer to purchase House C compared to House A and House B would be $\$ 6,607$ and $\$ 4,339$, respectively, assuming that the houses were in regular production. The energy savings of House $\mathrm{C}$ compared to House A and House B range from 5.3 to 16.0 MMBtu/yr when they are located in International Energy Conservation Code Zone 3 and Zone 4. Within this range of conditions, the simple paybacks to the homebuyer associated with building House $\mathrm{C}$ compared to House A and House B ranged from approximately 8.8 to $17.5 \mathrm{yr}$.

\footnotetext{
${ }^{3}$ Co-heat testing was used to measure whole-house heat loss and therefore effective envelope U-values. These data were used to tune the simulation parameters.

${ }^{4}$ It was not determined whether this finding can be generalized to other mini-split heat pumps.
} 


\section{Introduction}

Through field-testing and analysis, this project evaluated whole-building approaches and estimated the relative contributions of select technologies toward reducing energy use related to space conditioning in new manufactured homes. Three unoccupied lab houses of varying designs were built and tested side-by-side under controlled conditions in Russellville, Alabama (International Energy Conservation Code [IECC] Climate Zone 3).

The tests compared the performance of the three houses (referred to herein as House A, House B, and House C) built to different levels of thermal integrity. These tests allowed for a side-by-side comparison of actual whole-house performance focusing on the impacts that changes in envelope construction and heating, ventilating, and air-conditioning (HVAC) and distribution systems have on space-conditioning energy use. The houses had the following features: (1) House A was designed to best-practice thermal standards according to the U.S. Department of Housing and Urban Development (HUD) and equipped with an electric furnace and a split-system air conditioner; (2) House B was designed to comply with the requirements of the ENERGY STAR ${ }^{\circledR}$ program for manufactured homes, including an improved thermal envelope and a conventional split-system heat pump; and, (3) House C was designed to qualify for Zero Energy Ready Home (ZERH) designation according to the U.S. Department of Energy (DOE) and included a highefficiency, single-point, ductless mini-split heat pump with a transfer fan distribution system instead of the traditional duct system for distribution. House A and House B used a standard duct system for air distribution.

\section{Background and Literature Review}

Energy is one of the major contributors to homeownership costs, and high energy costs create a pronounced financial burden on households that have modest incomes. Manufactured homes in particular are susceptible to excessive energy costs because industry energy standards, nationally promulgated by HUD, were last updated in 1994. Programs such as ENERGY STAR and DOE's ZERH showcase ways to improve home efficiency and reduce energy costs. These efforts often incur higher construction costs (associated with enhanced efficiency) to achieve lower energy bills, a combination designed to yield lower net monthly homeowner costs.

\subsection{Literature Review}

In pockets of activity throughout the nation, researchers have conducted or are conducting field tests to explore better ways to build affordable, durable, comfortable, energy-efficient homes. These activities include a few studies using manufactured homes. Some include field-testing homes that have varying envelope characteristics and an array of high-performance HVAC systems. A few of these efforts are described below.

- Research that sought to estimate the energy savings associated with changes in building envelope characteristics and HVAC system efficiency includes work by Oak Ridge National Laboratory (Gehl et al. 2012) comparing three site-built side-by-side homes in Farragut, Tennessee, that had similar floor plans. One home was a typical builder house, the second contained high-efficiency HVAC system components (including an air source heat pump and sealed and insulated attic ducts fully inside the conditioned volume), and the third was built using optimum-value framing construction and was equipped with photovoltaic panels and a 
solar water-heating system. To simulate occupant load, the researchers programmed appliances, lights, and plug loads to run on a set schedule based on the Building America Research Benchmark protocol (Hendron and et al. 2006) (Hendron and Engebrent 2009). Compared to the standard home, Home 2 and Home 3 used $37 \%$ and $67 \%$ less energy, respectively.

- Similarly, Chasar, Chandra, and Parker et al. (2006) and Chasar, Chandra, and VanSchramm et al. (2010) compared three identical site-built homes of approximately 2,000 $\mathrm{ft}^{2}$ in San Antonio, Texas, a location that experiences both semiarid and humid subtropical conditions. Temperature and humidity data were recorded, and energy use was measured at a subsystem level, including heating, cooling, hot water, and major appliances. One of the homes was built to builder standard practice and served as the control home, and the other homes contained high-performance features. Researchers recorded utility peak electric load comparisons to assess the merits of various envelope and equipment improvements. The control home used natural gas for space and water heating, whereas one of the improved homes was equipped with a high-efficiency heat pump. Energy ratings for the homes yielded E-Scales (analogous to a Home Energy Rating System index) of 86 for the control home, 54 for one improved home, and 37 for the third home. (The latter included a $2.4-\mathrm{kW}$ photovoltaic array.) Relative to the control home, cooling energy savings ranged from 55\% to $77 \%$ for the two improved homes. Total demand reductions observed from the control and improved homes ranged from 6 to $8 \mathrm{~kW}(62 \%$ to $83 \%)$ on the hottest day during the utility peak period. Peak air-conditioning loads in the improved homes on the same day were reduced by 1.2 to $2.9 \mathrm{~kW}(28 \%$ to $68 \%)$ compared to the control. A $2.4-\mathrm{kW}$ grid-tied photovoltaic array on one home provided $60 \%$ of total electric energy needs during the hottest months, although the home was unoccupied during this period. During subsequent months when the home was occupied, the array provided approximately $30 \%$ to $40 \%$ of the total home electric needs.

- In a study performed in Grand Forks, North Dakota (Chasar et al. 2004), eight duplex units were built with the goal of achieving up to 50\% energy savings compared to the 1993 Model Energy Code. The actual comparison of energy use was provided by simulation with key data (such as infiltration rates) supplied by the field study. Of the eight homes, four were tighter and had more efficient HVAC systems and appliances than the Model Energy Code design, and four were progressively tighter than the first group. The results were the basis for costeffectiveness assessments. Combined gas and electric savings compared to the base case ranged from $25 \%$ (first group of homes) to $35 \%$ (second group).

- The Florida Solar Energy Center (2004) in association with North Carolina Agricultural and Technical State University compared the energy used by two manufactured homes placed side-by-side in a controlled field study. One home conformed to HUD standards; the other contained measures intended to reduce energy use by approximately 50\%. Modeling with Energy Gauge software predicted heating, cooling, and domestic hot water (DHW) savings of 57\%; and field measurements yielded 53\% savings. The homes were unoccupied, and the internal loads were simulated by incandescent lights on timers.

- The Zero Energy Manufactured Home (ZEMH) project examined two occupied, 1,600 $\mathrm{ft}^{2}$, double-section manufactured homes using identical floor plans (Lubliner and Hadley 2007). Remote monitoring equipment was installed to track the performance of each home during a 
3-yr period. Both homes were built in 2002 by Kit Manufacturing. A comparison home was built to ENERGY STAR program requirements as part of the Northwest Energy Efficient Manufactured Housing Program. Total energy use of the ZEMH was $29.4 \mathrm{kWh} / \mathrm{d}$, with 7.7 $\mathrm{kWh} / \mathrm{d}$ was covered by the photovoltaic array. The ZEMH showed $9 \%$ less energy use per year than the ENERGY STAR home, with 44\% less space-heating energy consumption despite having a higher occupant load than the ENERGY STAR home. The results were not normalized for occupant behavior.

- Pacific Northwest National Laboratory (2010) compared two identical, 1,500 $\mathrm{ft}^{2}$ manufactured homes located side-by-side to measure the impact of a variety of energy-saving measures on energy use and peak demand. A baseline home served as a control, typifying an average existing home in the Pacific Northwest. The second home was used to test new technologies. Occupancy was simulated following the protocol developed by the Pacific Northwest National Laboratory (Hendron and Engebrent 2009). Among the technologies evaluated were highly efficient windows (R-5) projected to save approximately $13 \%$ of the total whole-house energy use and reduce cooling-season peak demand by approximately $25 \%$. High-performance windows were also shown to improve thermal comfort through the moderation of radiant loads. However, the measure is expensive, and it has a long payback period (23 to $55 \mathrm{yr}$ ). The work continues, and the Pacific Northwest National Laboratory team plans to test other measures, including heat pump water heaters and low-emissivity storm windows. Table 1 summarizes the studies mentioned above and energy savings achieved.

Table 1. Summary of Past Lab House Research

\begin{tabular}{|c|c|c|c|c|c|}
\hline Author(s) & Location & Description of Houses & $\begin{array}{l}\text { Home } \\
\text { Size } \\
\left(\mathbf{f t}^{2}\right)\end{array}$ & $\begin{array}{l}\text { Occupancy } \\
\text { Simulation } \\
(\text { Yes/No) }\end{array}$ & $\begin{array}{l}\text { Savings } \\
\text { Relative } \\
\text { to Case } 1\end{array}$ \\
\hline $\begin{array}{l}\text { Oak Ridge } \\
\text { National } \\
\text { Laboratory } \\
\text { (2011) }\end{array}$ & $\begin{array}{l}\text { Farragut, } \\
\text { TN }\end{array}$ & $\begin{array}{l}\text { 1. Typical builder house } \\
\text { 2. Used energy-efficient } \\
\text { appliances, windows, air-to-air } \\
\text { heat pump, and insulated attic } \\
\text { 3. Built using optimum-value } \\
\text { framing construction with } \\
\text { photovoltaic modules and solar } \\
\text { water heating. }\end{array}$ & 2,400 & $\begin{array}{l}\text { Hendron's (2009) } \\
\text { test protocol was } \\
\text { used to simulate } \\
\text { occupancy in all } \\
\text { three houses } \\
\text { throughout the } \\
\text { testing period. }\end{array}$ & $\begin{array}{l}37 \%(2) \\
67 \%(3)\end{array}$ \\
\hline $\begin{array}{l}\text { Chasar et al. } \\
(2010)\end{array}$ & $\begin{array}{l}\text { San } \\
\text { Antonio, } \\
\text { TX }\end{array}$ & $\begin{array}{l}\text { 1. Typical builder house } \\
\text { 2. High-performance home with } \\
\text { 9.5 HSPF } / 18 \mathrm{SEER}^{\mathrm{b}} \text { heat pump, } \\
\text { tankless DHW boiler, } 100 \% \\
\text { fluorescent lights on } \\
\text { timers/occupancy sensors, and } \\
\text { energy-efficient appliances }\end{array}$ & 2,000 & $\begin{array}{l}\text { All three houses } \\
\text { were occupied } \\
\text { during most of } \\
\text { the testing time. }\end{array}$ & $\begin{array}{l}55 \%(2) \\
77 \%(3)\end{array}$ \\
\hline
\end{tabular}




\begin{tabular}{lllll}
\hline \multirow{2}{*}{ Author(s) Location } & Description of Houses & $\begin{array}{l}\text { Home Occupancy } \\
\text { Size } \\
\left(\mathbf{f t}^{2}\right)\end{array}$ & $\begin{array}{l}\text { Simulation } \\
(\text { Yes/No })\end{array}$ & $\begin{array}{l}\text { Relative } \\
\text { to Case 1 }\end{array}$ \\
& & &
\end{tabular}

3. Same as House 2 but with a tighter shell.

\begin{tabular}{|c|c|c|c|c|c|}
\hline $\begin{array}{l}\text { Chasar et al. } \\
(2010)\end{array}$ & $\begin{array}{l}\text { Grand } \\
\text { Forks, ND }\end{array}$ & $\begin{array}{l}\text { 1. Typical builder house (R-19 } \\
\text { wall insulation) } \\
\text { 2. As above with tighter shell } \\
\left(2.8 \mathrm{ACH} 50^{\mathrm{c}}\right), 70 \% \text { efficient } \\
\text { energy recovery ventilator } \\
\text { 3. As above with R-25 wall } \\
\text { insulation, } 2.4 \mathrm{ACH} 50 \\
\text { infiltration. }\end{array}$ & 1,840 & $\begin{array}{l}\text { Only computer } \\
\text { models were used } \\
\text { for each house; a } \\
\text { theoretical base } \\
\text { case house built } \\
\text { to local minimum } \\
\text { standards was } \\
\text { devised to } \\
\text { determine the } \\
\text { energy savings } \\
\text { and cost- } \\
\text { effectiveness. }\end{array}$ & $\begin{array}{l}25 \%(2) \\
35 \%(3)\end{array}$ \\
\hline $\begin{array}{l}\text { Florida } \\
\text { Solar } \\
\text { Energy } \\
\text { Center } \\
\text { (2004) }\end{array}$ & $\begin{array}{l}\text { Greensboro, } \\
\mathrm{NC}\end{array}$ & $\begin{array}{l}\text { 1. Basic HUD code standard } \\
\text { 2. } 50 \% \text { more energy efficient. }\end{array}$ & 1,528 & $\begin{array}{l}\text { The house } \\
\text { included } \\
\text { incandescent } \\
\text { lights for } 1.5 \\
\text { persons. Hot } \\
\text { water draws were } \\
\text { twice per day. }\end{array}$ & $\begin{array}{l}53 \%- \\
58 \%(2)\end{array}$ \\
\hline
\end{tabular}

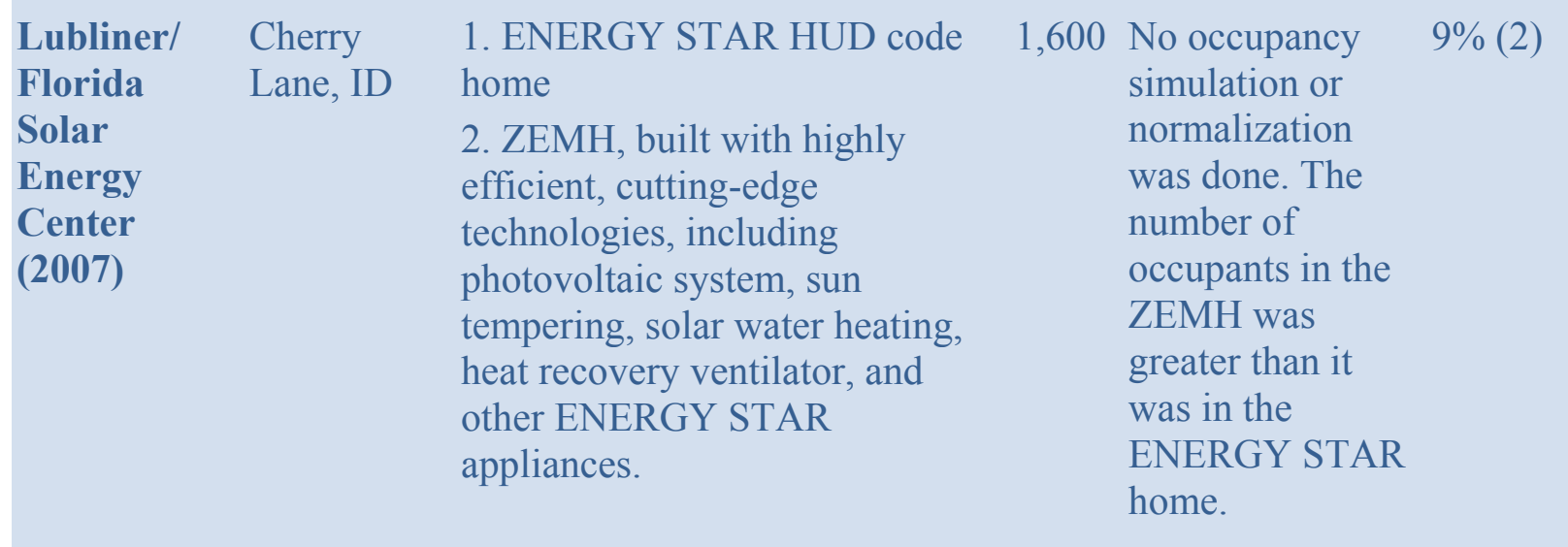

${ }^{a}$ Heating seasonal performance factor

${ }^{\mathrm{b}}$ Seasonal Energy Efficiency Ratio

${ }^{c}$ Air change per hour at 50 Pascals 


\subsection{Research Gaps and Relevance to Building America's Goals}

Relatively few efforts aimed at improving energy performance have looked at the challenge from a factory-built perspective and in particular the manufactured-home perspective. The best approaches for reducing energy use, improving indoor air quality, and increasing durability in homes constructed on-site are sometimes different from those built off-site. For example, the selection, design, and installation of the HVAC equipment and related distribution system are unique to factory building, and when they are viewed from an energy-efficiency standpoint they are a weak link.

Building America has a goal of developing cost-effective home-technology solutions to reduce whole-house source energy consumption by $50 \%$ compared to the 2009 IECC. This effort aims to do so for space-conditioning energy in an affordable-housing segment. This work builds on knowledge related to the performance of point-source space conditioning for low-load homes, an area on which a number of Building America teams have focused. A thorough summary of the Building America literature on this subject is included in work by Building Science Corporation (Ueno and Loomis 2015). Additionally, this work examines the impact of changes in thermal performance on collateral issues, particularly moisture performance, continuing the systems approach deeply embedded in Building America research.

\subsection{Research Questions}

This project addressed the following research questions:

- Can factory-built, manufactured homes meet the ZERH program requirements as defined? If not, what changes are suggested in the ZERH specifications to better reflect and take advantage of the unique aspects of factory building?

- What are the added costs and energy savings for manufactured ZERHs using ductless minisplit heat pumps compared to homes that adhere to best-practice HUD codes and ENERGY STAR manufactured homes?

- How does point-source space conditioning perform in a ZERH in terms of comfort? How do operational variables, such as opening and closing interior doors and window blinds and the operation of transfer fans, impact performance in heating and cooling modes?

- What is the in-situ coefficient of performance (COP) in heating and cooling modes of a ductless mini-split heat pump? 


\section{Whole-Building Performance Assessment}

This section profiles the whole-building assessment process conducted during a full heating and cooling season in Russellville, Alabama. The discussion covers the approach and process for setting up the experiment (house design and procurement, siting, commissioning, operation and monitoring protocol), results, and data analysis.

\subsection{Approach}

Three manufactured homes were built and colocated on a site adjacent to the SEhomes homebuilding facility in Russellville, Alabama. The houses varied only in the technologies being evaluated. They were operated for 15 months, and data was intensively monitored. The experiment assessed the following strategies for reducing energy use:

1. Thermal envelope technologies. The manufactured-home walls use exterior rigid foam insulation, enhanced air sealing, and highly insulated low-slope roofs utilizing a new dense-pack roof insulation technique.

2. Site-installed heat pumps. Site-installed, split-system heat pumps are used in the construction of manufactured homes in the Southeast, the location of the tests, and they are required for homes qualifying for ENERGY STAR designation. However, their contribution toward energy use reduction and the specific performance characteristics of heat pumps when used with homes adhering to HUD code have not been verified in the field.

3. Ductless mini-split heat pumps. Ductless heat pumps can be fully installed and commissioned during home manufacturing in the plant and transported to the site, ready for operation. They are used in place of a typical furnace and split-system cooling equipment; the latter are completed at the site during the home setup. Ductless heat pumps offer the following advantages:

A. By replacing central ducted systems, ductless heat pumps eliminate the associated distribution issues and comfort problems that often accompany poor supply register locations and losses due to duct leakage.

B. They typically incorporate inverter-driven compressors and variable-speed fan technology, which results in very high efficiencies of up to 27 SEER and 12.5 HSPF, much higher than standard heat pumps.

C. They free up space within the home usually devoted to heating and cooling equipment.

D. They provide both heating and cooling, offering a total space-conditioning solution in a single device.

E. They can be fully installed in the plant. This ensures that the home will have a heat pump, and it enables strict plant oversight and inspections that guarantee consistent installation quality and proper commissioning.

F. A single, wall-mounted outside compressor can be connected to numerous independently controlled air handling units, which facilitates flexible zoning of spaces and reduces over-/under-space conditioning. 
G. The compressor is mounted outside, which reduces interior noise compared to most compact, unitary air-conditioning/heat pump systems.

H. They eliminate the possibility of mismatched indoor and outdoor equipment.

I. They are available in small capacities (as low as 9,000 Btu/h) that are suitable for low-load buildings, such as small manufactured homes.

\subsection{Experimental Method}

\subsubsection{Designs}

Three side-by-side lab houses were built in Russellville, Alabama: one that conforms to bestpractice HUD standards (House A), one that complies with the manufactured-home ENERGY STAR program (House B), and one that meets DOE's ZERH criteria (House C). The prototypes were identical (floor plan, orientation, construction) except for the differences associated with the measures listed in Table 2. Construction drawings are provided in Appendix J.

Table 2. Lab House Specifications

\begin{tabular}{|c|c|c|c|}
\hline Items & House A & House B & House C \\
\hline Floor & $\begin{array}{l}\text { R-14 fiberglass } \\
\text { blanket }\end{array}$ & $\begin{array}{l}\text { R-28 fiberglass } \\
\text { blanket }\end{array}$ & R-28 fiberglass blanket \\
\hline Flooring & $60 \%$ carpet; $40 \%$ vinyl & $60 \%$ carpet; $40 \%$ vinyl & $60 \%$ carpet; $40 \%$ vinyl \\
\hline Wall & $\begin{array}{l}1 / 2 \text {-in vinyl-covered } \\
\text { drywall, R-11 } \\
\text { fiberglass batts, } 1 / 4 \text {-in } \\
\text { ThermalStar board }(\mathrm{R}- \\
\text { 1) }(\text { perm rating }>5) \text {, } \\
\text { light-colored vinyl } \\
\text { siding }\end{array}$ & $\begin{array}{l}\text { 1/2-in vinyl-covered } \\
\text { drywall, R-13 } \\
\text { fiberglass batts, } 1 / 4 \text {-in } \\
\text { ThermalStar board }(\mathrm{R}- \\
\text { 1) (perm rating }>5) \text {, } \\
\text { light-colored vinyl } \\
\text { siding }\end{array}$ & $\begin{array}{l}\text { 1/2-in vinyl-covered } \\
\text { drywall, R-13 + R-5 (1-in. } \\
\text { extruded polystyrene) } \\
\text { (perm rating } 1.5), \text { light- } \\
\text { colored vinyl siding }\end{array}$ \\
\hline Windows & $\begin{array}{l}\text { U: } 0.47 \text {, SHGC: } 0.73 \text {; } \\
\text { single pane, metal } \\
\text { frame }\end{array}$ & $\begin{array}{l}\text { U:0.31, SHGC: } 0.33 \text {, } \\
\text { double pane, vinyl } \\
\text { frame, low-emissivity, } \\
\text { air filled }\end{array}$ & $\begin{array}{l}\text { U: } 0.30 \text {, SHGC: } 0.23 \text {, } \\
\text { double pane, vinyl frame, } \\
\text { low-emissivity, argon } \\
\text { filled }\end{array}$ \\
\hline Ceiling & $\begin{array}{l}\text { R- } 22 \text { blown fiberglass, } \\
\text { vented roof cavity } \\
\text { with asphalt shingles }\end{array}$ & $\begin{array}{l}\text { R-33 blown fiberglass, } \\
\text { vented roof cavity } \\
\text { with asphalt shingles }\end{array}$ & $\begin{array}{l}\text { R-45 blown fiberglass, } \\
\text { dense-packed at eaves, } \\
\text { vented roof cavity with } \\
\text { asphalt shingles }\end{array}$ \\
\hline Air Sealing & $\begin{array}{l}\text { Standard plant practice } \\
\text { including foaming } \\
\text { ceiling penetrations, } \\
\text { caulking under bottom } \\
\text { plates and between top } \\
\text { plates and ceiling, } \\
\text { marriage line gasket }\end{array}$ & $\begin{array}{l}\text { Standard plant practice } \\
\text { including foaming } \\
\text { ceiling penetrations, } \\
\text { caulking under bottom } \\
\text { plates and between top } \\
\text { plates and ceiling, } \\
\text { marriage line gasket }\end{array}$ & $\begin{array}{l}\text { Standard plant measures } \\
\text { plus foaming around } \\
\text { window and door rough } \\
\text { openings, patching/ } \\
\text { foaming floor } \\
\text { penetrations, taping foam } \\
\text { sheathing joints, caulking }\end{array}$ \\
\hline
\end{tabular}




\begin{tabular}{llll}
\hline Items & House A & House B & House C \\
\hline & & & $\begin{array}{l}\text { foam sheathing to top and } \\
\text { bottom plates, spray foam } \\
\text { along marriage line }\end{array}$ \\
$\begin{array}{llll}\text { Mechanical } \\
\text { Ventilation }\end{array}$ & $\begin{array}{l}\text { Fresh air duct to air } \\
\text { handling unit, no } \\
\text { mechanical damper }\end{array}$ & $\begin{array}{l}\text { Fresh air duct to air } \\
\text { handling unit, no } \\
\text { mechanical damper }\end{array}$ & $\begin{array}{l}\text { 45 cfm exhaust fan } \\
\text { Space- }\end{array}$ \\
$\begin{array}{l}\text { Metal in-floor ducts } \\
\text { Distribution }\end{array}$ & $\begin{array}{l}\text { Metal in-floor ducts } \\
\text { sealed with mastic, R- }\end{array}$ & $\begin{array}{l}\text { sealed with mastic, R- } \\
8 \text { crossover duct }\end{array}$ & $\begin{array}{l}\text { AS1 transfer fan, 21 W } \\
\text { between home }\end{array}$ \\
& $\begin{array}{l}\text { between home } \\
\text { sections }\end{array}$ & $\begin{array}{l}\text { MBR and MBath: } \\
\text { Tjernlund AS2 transfer } \\
\text { fan, 33 W }\end{array}$ \\
\hline
\end{tabular}


Table 3. Cooling and Heating Equipment Specifications

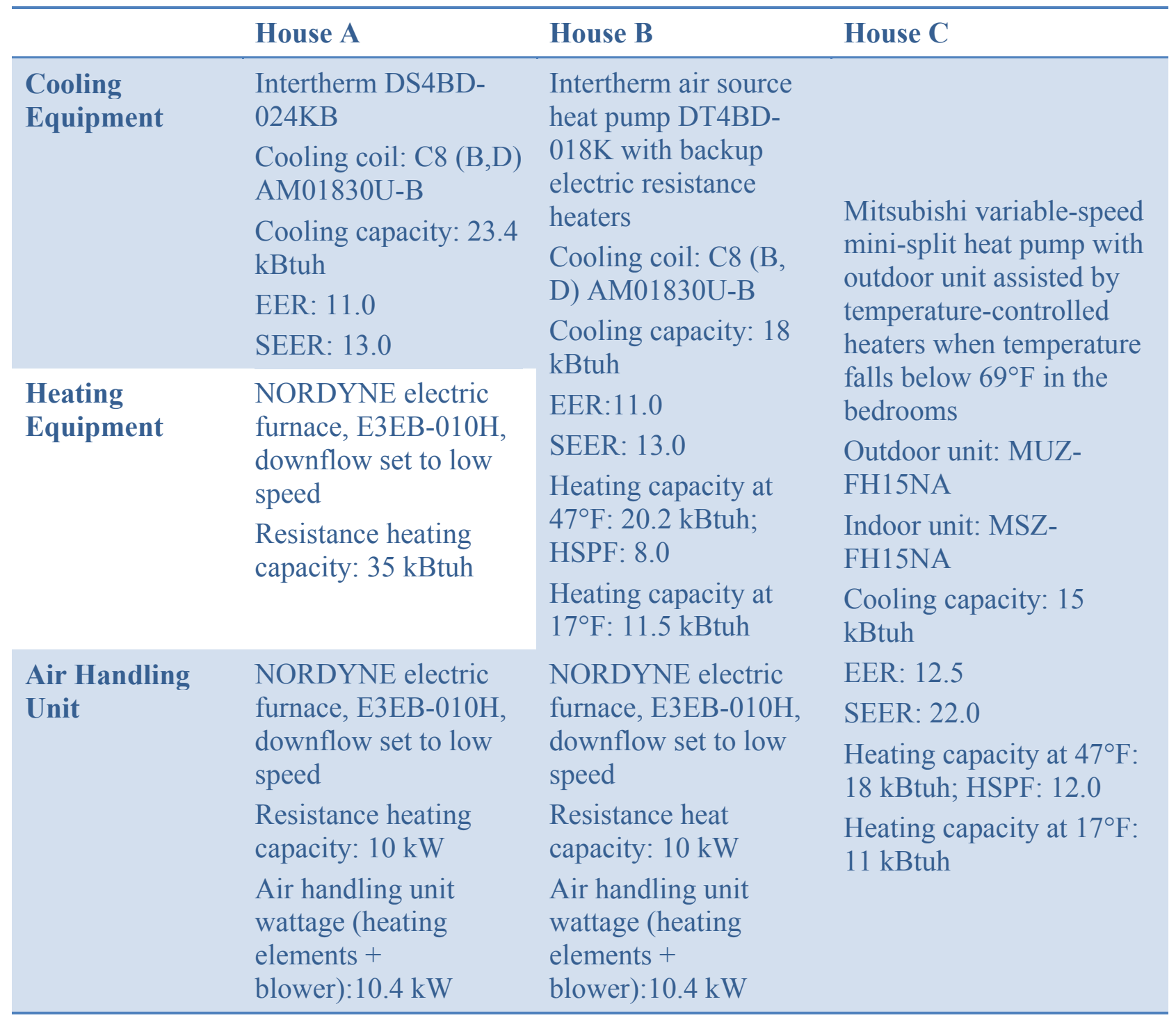

The floor plan for House A and House B is shown in Figure 1. The only changes to House C were the elimination of the furnace, relocation of the water heater to the furnace closet (to reduce DHW pipe lengths), and enlargement of the Bedroom 2 closet to include the former water heater compartment. 


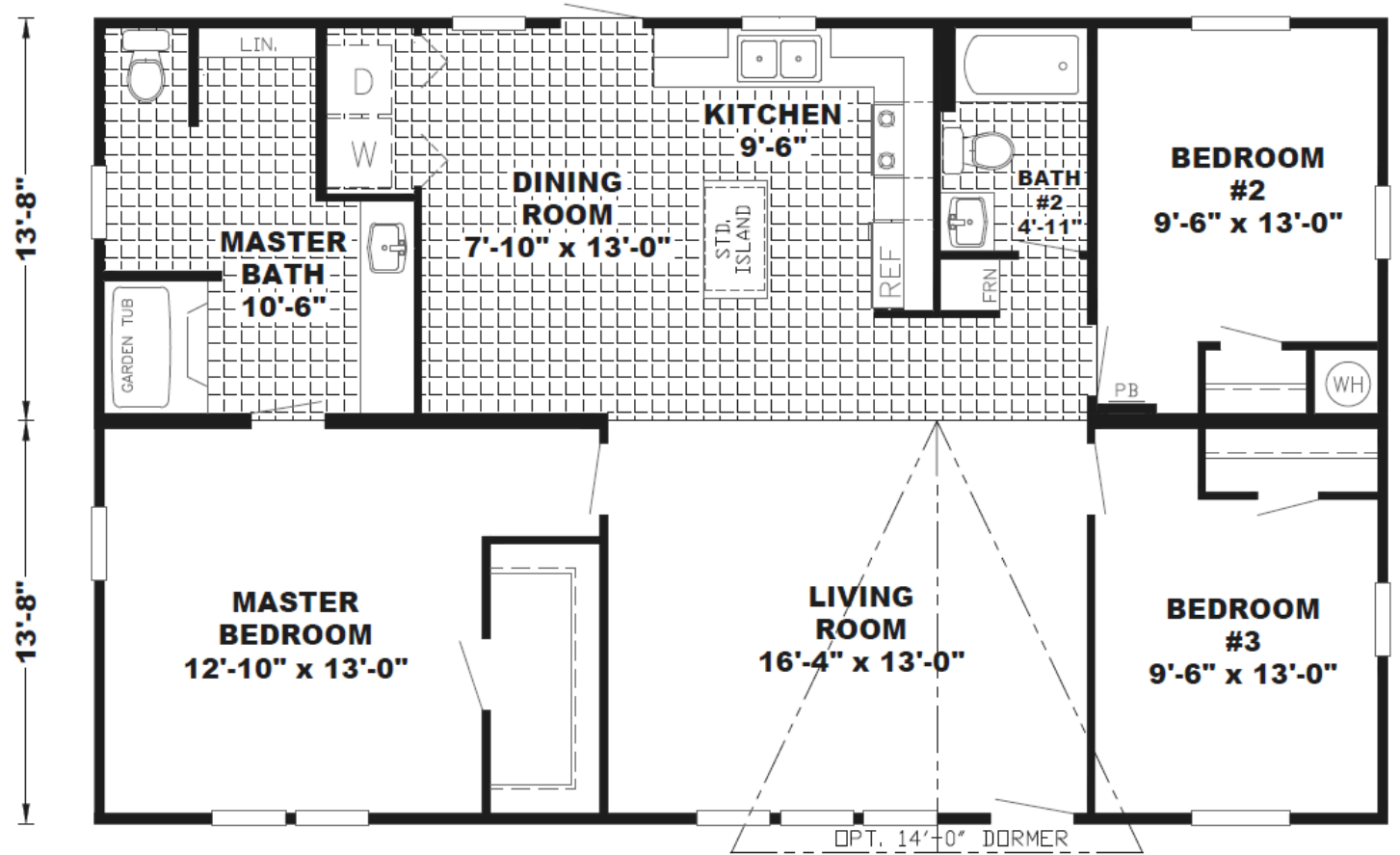

Figure 1. Floor plan 


\subsubsection{Acquisition}

The homes were purchased from a single manufacturing plant and inspected during manufacture to ensure that the construction methods were consistent and uniform (Figure 2).
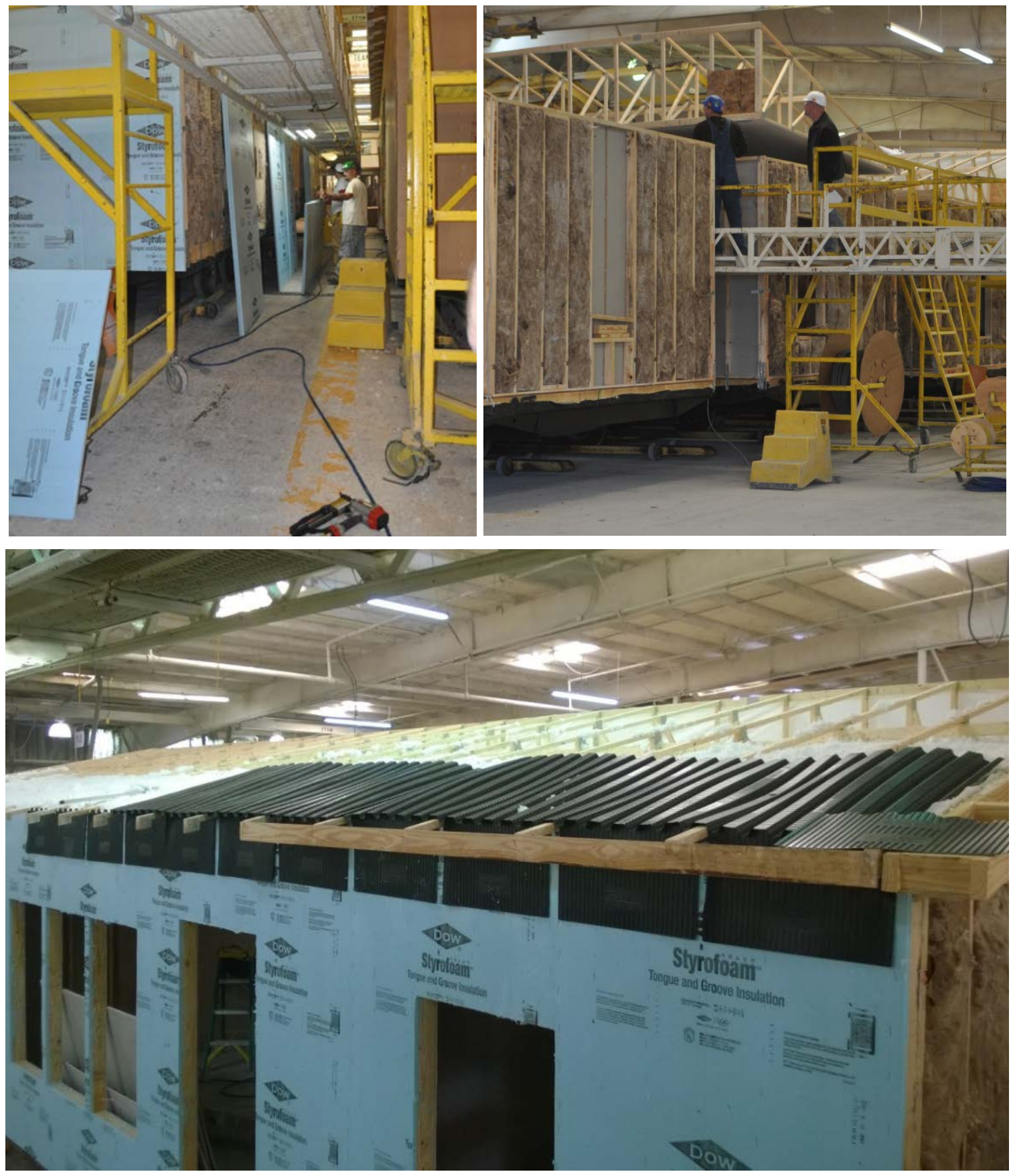

Figure 2. Lab house production 
To ensure maximum protection against moisture and minimize envelope infiltration, window flashing systems were applied to the extruded polystyrene, as shown in Figure 3.
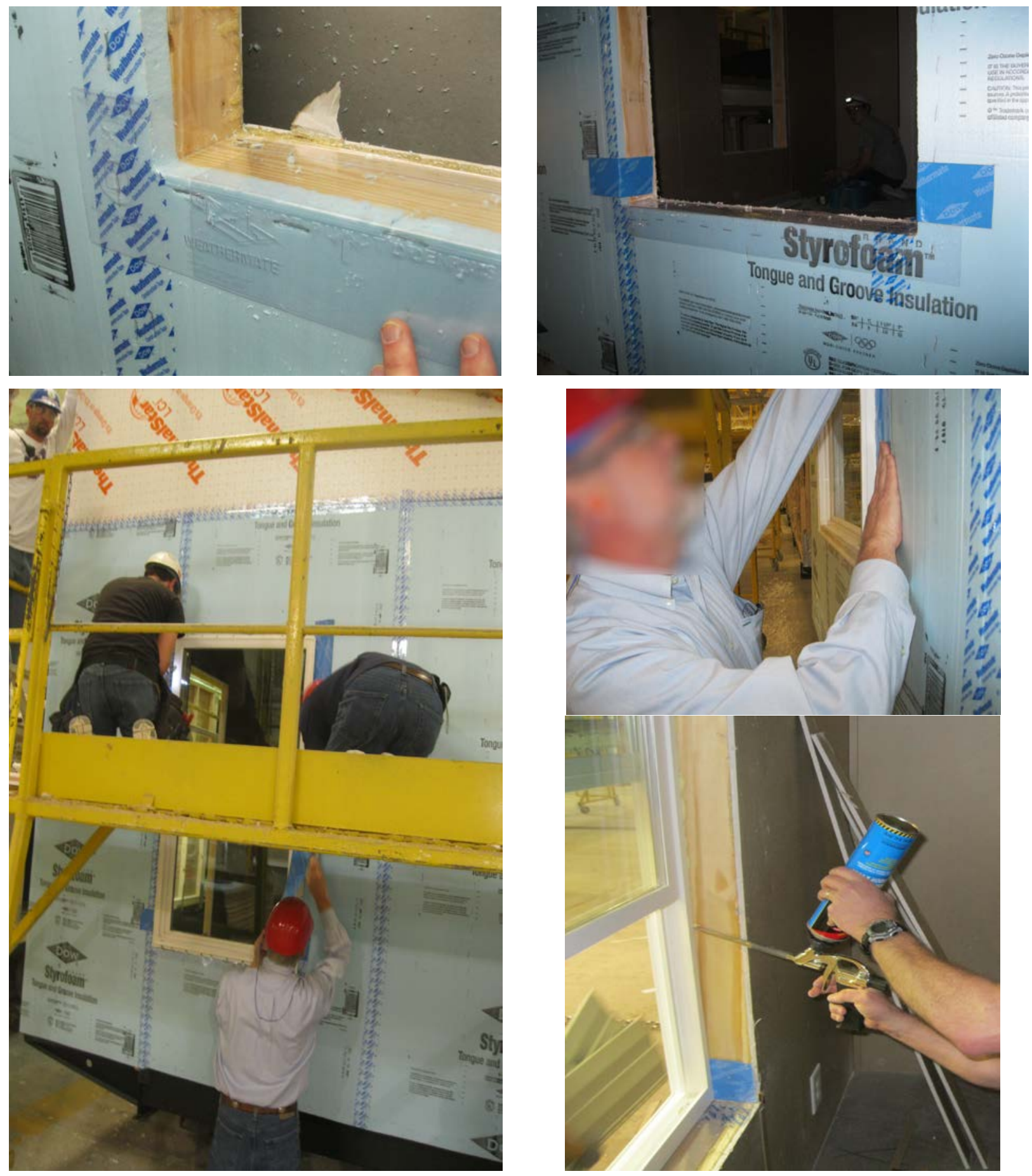

Figure 3. Window flashing system in House C 


\subsubsection{Siting}

The homes were installed adjacent to the manufacturing plant for a period of approximately 15 months. The orientation and solar exposure were identical for all homes (Figure 4).
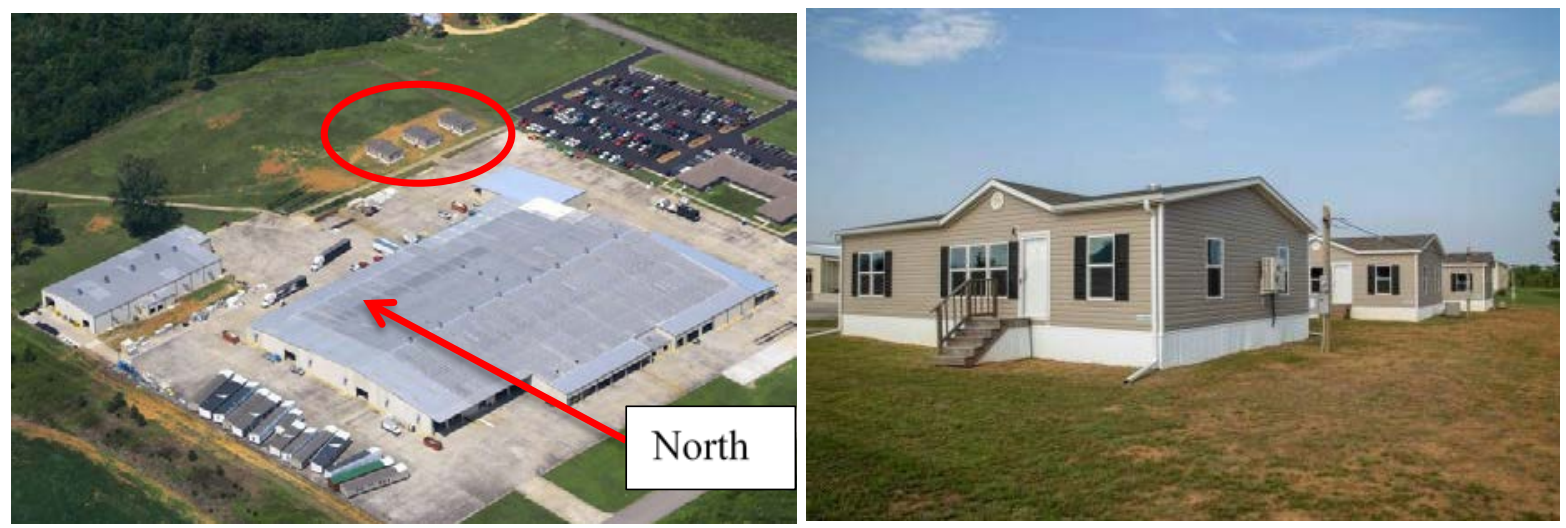

Figure 4. Lab house site

\subsubsection{Commissioning}

The homes were commissioned for the monitoring effort by establishing baseline conditions. A summary of commissioning test results is provided in Table 4, with additional details in Appendix A. Due to the influence of ENERGY STAR requirements on manufactured homes, most of the manufactured-home plants in the United States use similar techniques for reducing enclosure and duct leakage in all newly constructed homes. Therefore, the enclosure leakage in House A is nearly the same as it is in House B. Thus, compared to older manufactured homes in the field, House A is considered a best-practice HUD home. 
Table 4. Commissioning Tests

\begin{tabular}{lll}
\hline Test & Equipment/Method & Results \\
\hline Enclosure & Energy Conservatory blower door & A: $4.7 \mathrm{ACH} 50$ \\
Leakage & multipoint depressurization test & B: $4.6 \mathrm{ACH} 50$ \\
& C: $3.8 \mathrm{ACH} 50$ \\
Duct Leakage & $\begin{array}{l}\text { Energy Conservatory duct blaster } \\
\text { depressurization test }\end{array}$ & A: $54 \mathrm{cfm} 25$ to outside \\
& & B: $\sim 10 \mathrm{cfm} 25$ to outside \\
& & C: N/A \\
Ventilation Rate & Energy Conservatory FlowBlaster & A: 44 intermittent \\
& & B: 32 intermittent \\
Air Handling & Energy Conservatory duct blaster & A: 980 continuous \\
Unit Air Flow & & B: $1,000 \mathrm{cfm}$ \\
Supply Register & Energy Conservatory FlowBlaster & C: variable \\
Air Flows & & See Appendix A \\
\hline
\end{tabular}

Note that the air handling unit air flow rates for House A and House B are high relative to the loads for optimal humidity control, even at the lowest speed. Nevertheless, this was the plant's standard air handling unit used for production homes. This would result in lower moisture removal in an occupied home; however, latent loads were not simulated in these unoccupied lab homes.

Air flow rates at a variety of power draws were measured for the variable-speed mini-split heat pump air handling unit in House $\mathrm{C}$. These flows were later used in the investigation of heat pump COP. The resulting fan curve is shown in Figure 5. 


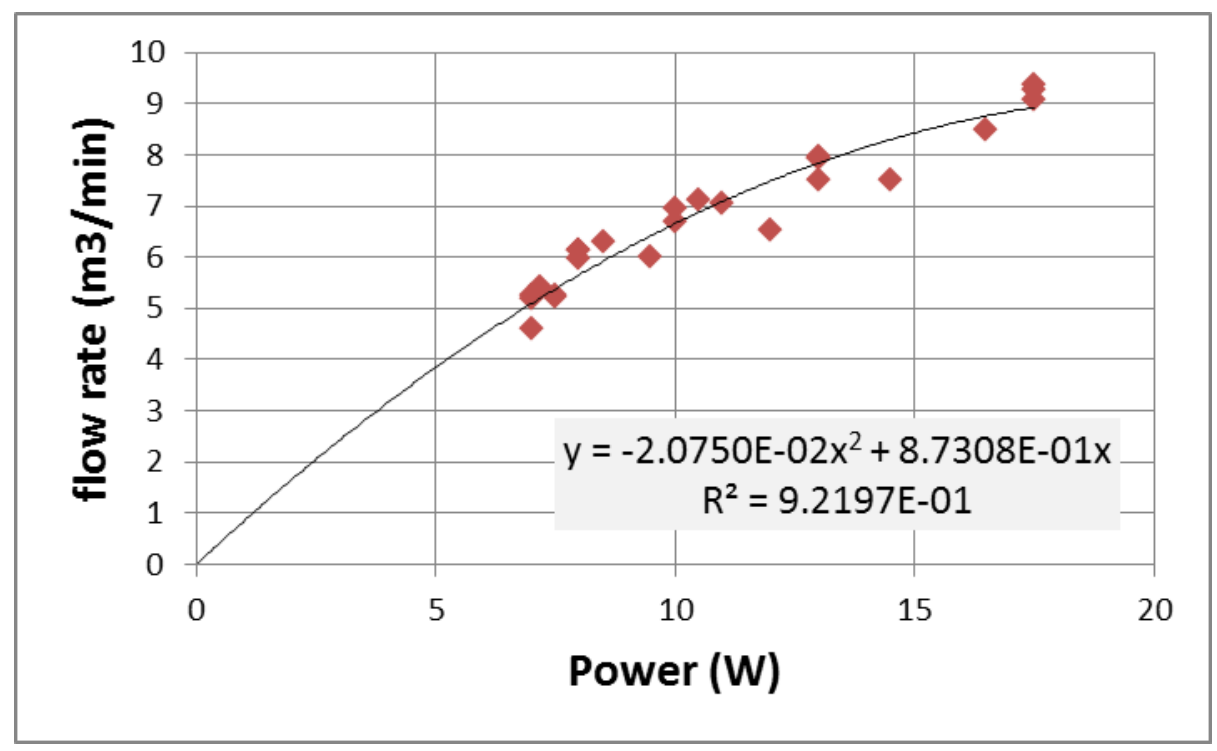

Figure 5. House $\mathrm{C}$ heat pump fan curve

\subsubsection{Operation}

The homes were operated in an identical manner, including interior temperatures and simulation of occupant loads.

- Primary thermostat set points. The heating set point was $71^{\circ} \mathrm{F}$, and the cooling set point was $76^{\circ} \mathrm{F}$. To maintain an average house temperature (average of all rooms) of $76^{\circ} \mathrm{F}$ during the cooling season, the heat pump in House $\mathrm{C}$ was placed on a setback schedule of $75^{\circ} \mathrm{F}$ from 8:00 p.m. to $10: 00$ a.m. and $73^{\circ} \mathrm{F}$ from 10:00 a.m. to 8:00 p.m. This was necessary to obtain average space temperatures comparable to House A and House B.

- Secondary heating (House C) set point. Auxiliary electric resistance heaters were used to supply backup heat to the House $\mathrm{C}$ bedrooms and master bathroom. These heaters were set to $9^{\circ} \mathrm{F}$.

- Transfer fans (House C) set point. Through-wall transfer fans in House C were set on independent thermostats in each room to which the fans delivered air. These thermostats were set to activate the fan at an upper set point of $76^{\circ} \mathrm{F}$ during the cooling season and at $69^{\circ} \mathrm{F}$ during the heating season. Short-term tests were conducted with the fans deactivated to study their impact on room temperatures and energy use. Thermostat control was used so fans would run only when heating or cooling was needed in the rooms they served.

- Occupant loads. Sensible internal heat gain was simulated through the use of electric resistance heaters controlled by the data loggers. Figure 6 shows the schedule of loads.

Latent internal heat gains can also impact energy consumption and comfort; however, latent loading is more complex to simulate. Latent loads have been simulated through the use of ultrasonic humidifiers by the National Renewable Energy Laboratory (Fang et al. 2011). It was estimated that these homes would require approximately $1.5 \mathrm{gal} / \mathrm{d}$ of water delivered to the air. Because the homes were in a remote location and not attended regularly, there was limited opportunity to inspect the humidification equipment. Further, the homes were not connected to 
water service. Because the systems would have had to run unattended for long periods, large water tanks (100-200 gal per home) using deionized water would have been required to reduce the need for humidifier maintenance, or frequent descaling would have been required. Risks associated with this approach include undetected leaks, malfunction of the humidification system, and biological growth in the water tanks. Therefore, internal latent loads were not simulated. However, a short-term humidification test was conducted in each home to assess the dehumidification capability of the equipment.

It is acknowledged that this may lead to greater variability in the results; eliminating latent internal loads could potentially impact the three houses differently. Additionally, measurements of moisture levels in the wall cavities were possibly underestimated along with attendant risks of condensation.

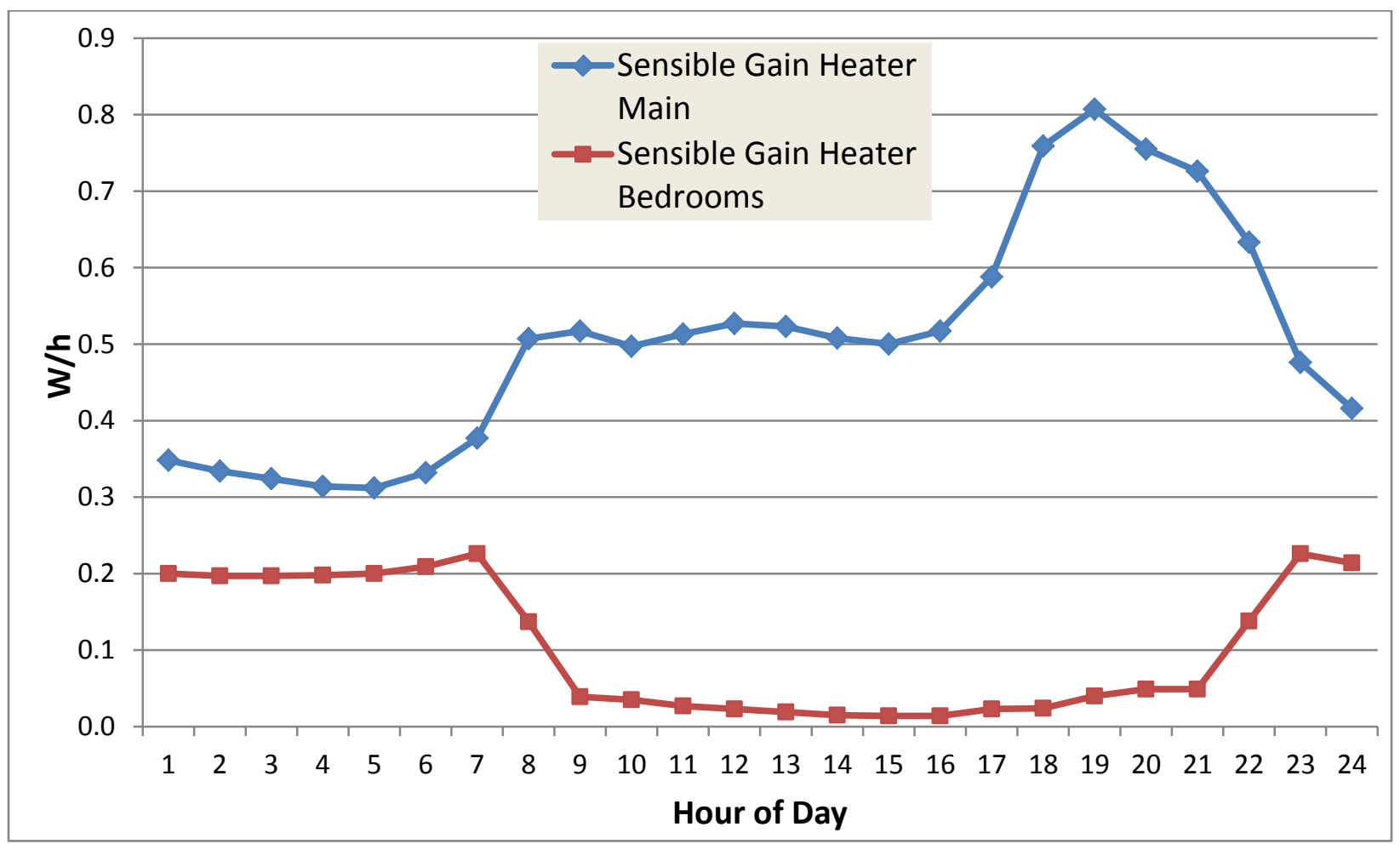

Figure 6. Sensible load profiles

- Interior doors. Because the field data was compared to single-zone Building Energy Optimization software (BEopt) model simulation, the interior doors were kept open for the majority of the testing period. To characterize the temperature distribution across the homes with the doors closed, short-term tests (5-10 d) were conducted during the cooling and heating seasons with the doors closed.

- Window blinds. For the majority of the monitoring period, the blinds were kept $50 \%$ closed. Short-term tests were conducted with the blinds fully open and fully closed.

\subsubsection{Measurements}

The homes were monitored for 15 months with 1-min data uploaded on a daily basis. CR1000 data loggers in conjunction with multiplexers were used for the data acquisition. Key metrics, 
such as equipment operation and internal temperatures, were reviewed periodically to verify that the homes were operating as intended. Monitoring points and equipment included the following (see also Appendix B):

- Air temperature. Watlow T-type thermocouples in conjunction with aspirated shields were used to measure space air temperatures at five locations in each home at $5 \mathrm{ft}$ above the floor (mounted on tripods) and at least $5 \mathrm{ft}$ away from the heating/cooling/air distribution systems and exterior walls. A crawl space temperature sensor was placed at the center of the crawl space approximately $1.5 \mathrm{ft}$ above grade. An attic air temperature sensor was placed at the center of the attic above the insulation.

- Air temperature and relative humidity. A Campbell Scientific CS215 temperature and relative humidity probe was used to measure the temperature and relative humidity at one location in each home. The same sensor type was also used to measure the outdoor air temperature and relative humidity at one location in all three homes. To protect the outdoor sensor from the elements, a protection shield was used.

- Condensation. In House B and House C, Campbell Scientific CS215 temperature and relative humidity probes were used to measure the air temperature and relative humidity of the surface between the exterior sheathing (extruded polystyrene insulation) and interior fiberglass insulation on a north-facing wall approximately 32 in. above the floor. An Omnisense S900-1 sensor was used to measure the moisture content of the lower exterior corner of a stud in the same north-facing wall. The data from these sensors was used to predict the propensity for moisture accumulation in the exterior wall.

- Power consumption. Power current transducers in conjunction with Wattnode energy-topulse transducers measured the power of HVAC equipment and total house power.

- Status. Hawkeye 300 (Veris H300) go/no-go current switches were used to measure the status of the reversing valves of the heat pumps.

- Current. The compressor and fan current were measured by Veris H721LC sensors.

- Solar radiation. A Campbell LI200X-L silicon pyranometer was used to measure the solar radiation at the site.

In addition to the long-term monitoring system, a series of short-term measurements were made:

- Co-heat testing. Short term co-heat testing in cold weather using portable electric resistance space heaters was conducted in all three houses to measure whole-house heat loss. The test data was used to obtain envelope U-value (overall heat transfer coefficient) information in each house and provide better quantification of simulation parameters. During the test, six portable heaters (one in each bedroom, one in the master bathroom, one in the living room, and one in the kitchen) were used to maintain $70^{\circ} \mathrm{F}$ throughout the test. Other heating equipment was switched off. Temperature sensors were used to turn the heaters on and off through the Campbell Scientific data loggers.

- Tracer gas decay testing. Infiltration was measured in all three homes utilizing tracer gas. The objectives of the tracer gas testing were to determine infiltration levels in all three 
houses for calibrating models and quantifying the effectiveness of the ventilation systems in all three houses.

- Humidification testing. The dehumidification capability of the equipment was tested. The objective of this test was to measure the humidity levels in each house during near-peak humidity conditions to assess the capability of the cooling equipment to maintain comfort conditions.

\subsection{Monitoring Results}

This section describes the results of the tests noted above. It characterizes typical performance in terms of HVAC energy consumption, comfort, moisture, and peak energy demand. The analysis section that follows generalizes the data to annual whole-house energy consumption at various locations using calibrated energy models.

\subsubsection{Cooling Season HVAC Energy}

A representative cooling season period that exhibited a wide range of outdoor temperatures was selected for analysis. During this period-from August 29, 2014, through September 15, 2014 the interior doors were open and the window blinds were $50 \%$ closed.

A plot of cooling power relative to ambient temperature for this period shows that House $\mathrm{C}$ used less cooling energy than did the other houses at outdoor temperatures in excess of approximately $24^{\circ} \mathrm{C}\left(75^{\circ} \mathrm{F}\right)$ (Figure 7$)$. House B used somewhat less cooling energy than did House A when temperatures rose above approximately $25^{\circ} \mathrm{C}$. At lower temperatures, House A used less cooling energy than did House B. This inversion may have occurred because House A's lower insulation values and higher ventilation rate allowed more natural cooling, whereas the better insulated House B held the heat longer. (Both homes had similar airtightness.) This was especially prevalent after sunset when the lower solar heat gain through the windows of House B no longer provided an advantage over House A. 


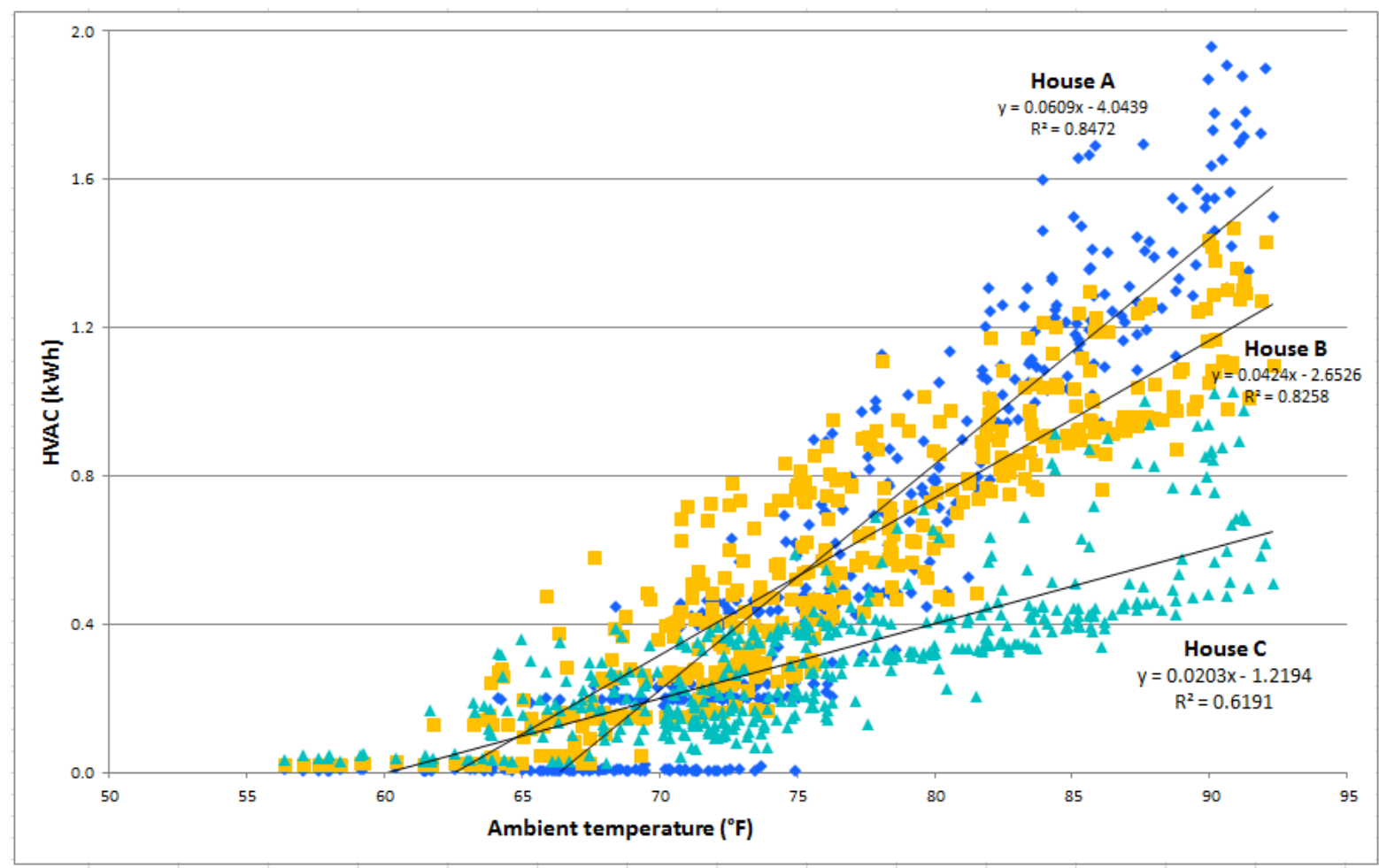

Figure 7. Cooling power relative to outdoor temperature for all three houses

(Aug. 29-Sept. 15, 2014)

Table 5 summarizes the cooling performance of all three houses. During this typical summer period, House $\mathrm{C}$ used half as much HVAC energy as did the other houses. House B used slightly less than House A did for cooling. Average indoor temperatures were similar and close to thermostat set points. Average relative humidity was slightly higher in House C, but it was still within acceptable limits. Note that during this period House C's fresh air ventilation rate was approximately 3.5 times higher than that of the other houses (meeting the American Society of Heating, Refrigerating, and Air-Conditioning Engineers [ASHRAE] Standard 62.2-2010), which contributed to the higher humidity. If ventilation rates in House A and House B were to have met the standard, the difference between the cooling energy consumption of House $\mathrm{C}$ and the others would have been greater. Also, although relative humidity was higher in House $\mathrm{C}$, it is likely that other indoor air quality pollutant levels were lower because of the higher fresh-air ventilation rate. 
Table 5. Cooling Statistics (Aug. 29-Sept. 7, 2014)

\begin{tabular}{cccc}
\hline & House A & House B & House C \\
\hline Total Cooling (Avg. kWh/d) & 15.0 & 14.5 & 7.4 \\
\hline Average Indoor Temp. $\left({ }^{\circ} \mathrm{F}\right)$ & 76.4 & 75.9 & 75.4 \\
\hline Cooling Set Point ( $\left.{ }^{\circ} \mathrm{F}\right)$ & 76.0 & 76.0 & $73.0-75.0$ \\
\hline Avg. Relative Humidity (\%) & $46 \%$ & $48 \%$ & $59 \%$ \\
\hline Air Handling Unit Fan Run Time & $31 \%$ & $37 \%$ & $100 \%$ \\
\hline $\begin{array}{c}\text { Ventilation-Effective Continuous } \\
\text { Rate (cfm) }\end{array}$ & 14 & 12 & 45 \\
\hline
\end{tabular}

\subsubsection{Transfer Fan Operation}

In House $\mathrm{C}$, transfer fan thermostats were set to $76^{\circ} \mathrm{F}\left(24.4^{\circ} \mathrm{C}\right)$; that is, they would turn on when the thermostat controlling the fan reached that temperature. During these periods, the fans serving the rooms that had southern exposure (master bedroom and master bathroom) were on the highest percentage of the time (Table 6). The fan serving the northeast bedroom ran the least frequently.

Table 6. Transfer Fan Run Time (Aug. 29-Sept. 7, 2014)

\begin{tabular}{cc}
\hline Transfer Fan Location & Run Time (\%) \\
\hline Bedroom 2 (Northwest) & 25 \\
\hline Bedroom 3 (Northeast) & 12 \\
Master Bedroom (Southeast) & 55 \\
Master Bathroom (Southwest) & 49 \\
\hline
\end{tabular}

\subsubsection{Cooling Use When Outdoor Temperatures Were Below Indoor Cooling Target} The target temperature for all three houses during cooling was $76^{\circ} \mathrm{F}\left(24.4^{\circ} \mathrm{C}\right)$. The table and graphs below (Table 7, Figure 8, Figure 9, and Figure 10) identify hours during two weeks in the summer of 2014 when the cooling systems were operating coincident with outdoor air temperatures below this target cooling temperature. Opening windows during these conditions can provide free cooling and reduce overall HVAC energy consumption. As expected, the leakier and less thermally efficient the enclosure, the lower the proportion of cooling energy expended during these periods because daytime heat more rapidly dissipated to the outside. By opening windows and venting daytime heat that has built up, occupants would have had the opportunity to reduce cooling energy by up to $37 \%$ in House C, $33 \%$ in House B, and $22 \%$ in House A. 
Table 7. Cooling Energy Consumption (Aug. 29-Sept. 15, 2014)

\begin{tabular}{cccc}
\hline & House A & House B & House C \\
\hline $\begin{array}{c}\text { Time When Cooling Is Provided, } \\
\text { When Outdoor Temp. Is Below 76 } \mathbf{F}^{\mathbf{F}} \mathbf{( \% )}\end{array}$ & 251 & 244 & 138 \\
\hline $\begin{array}{c}\text { Cooling Energy Consumption Not Required } \\
(\% \text { Cooling Energy During Hours as Defined } \\
\text { in Row })\end{array}$ & 22 & 33 & 37 \\
\hline
\end{tabular}

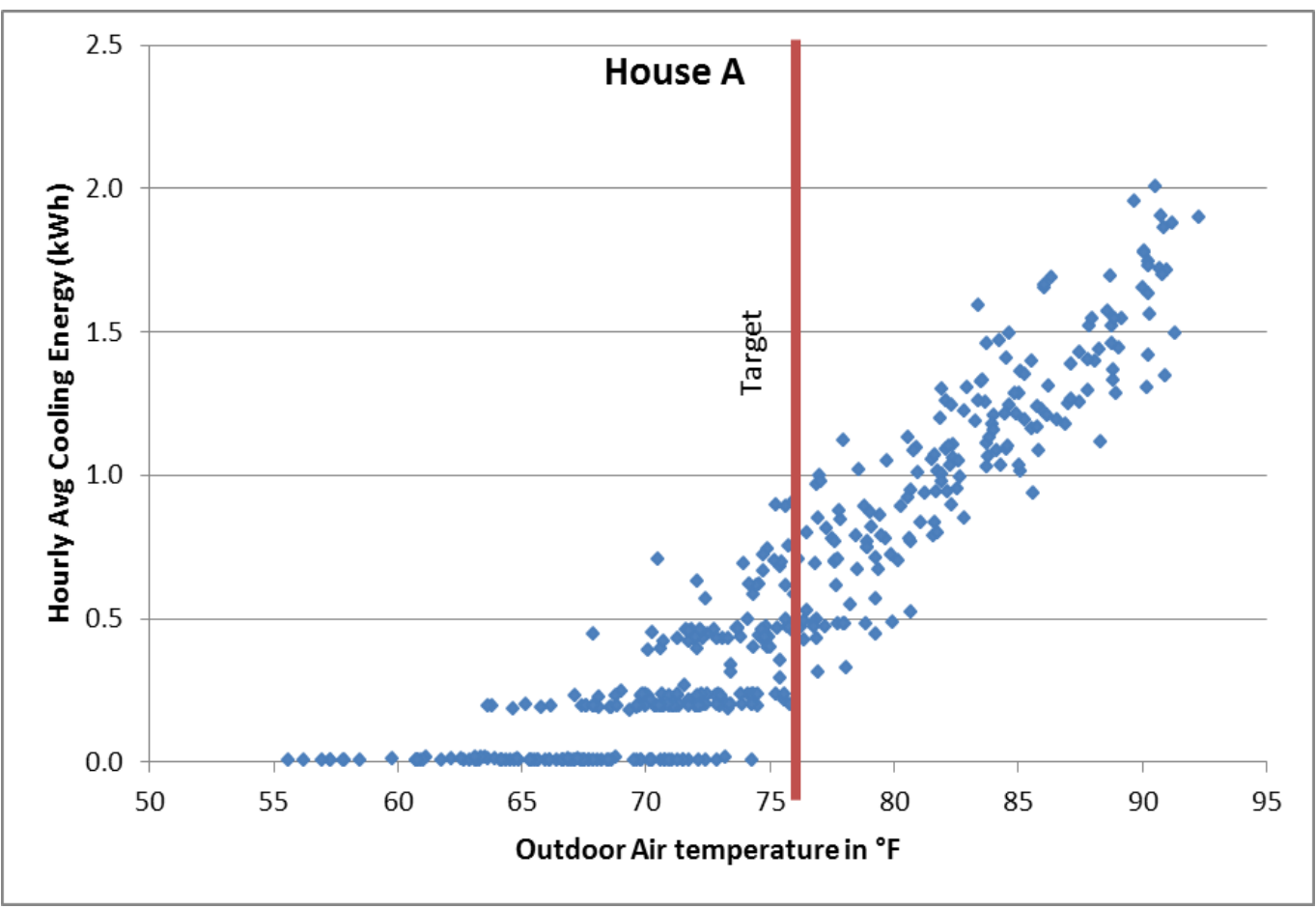

Figure 8. House A cooling energy consumption at various outdoor temperatures (Aug. 29-Sept. 15, 2014) 


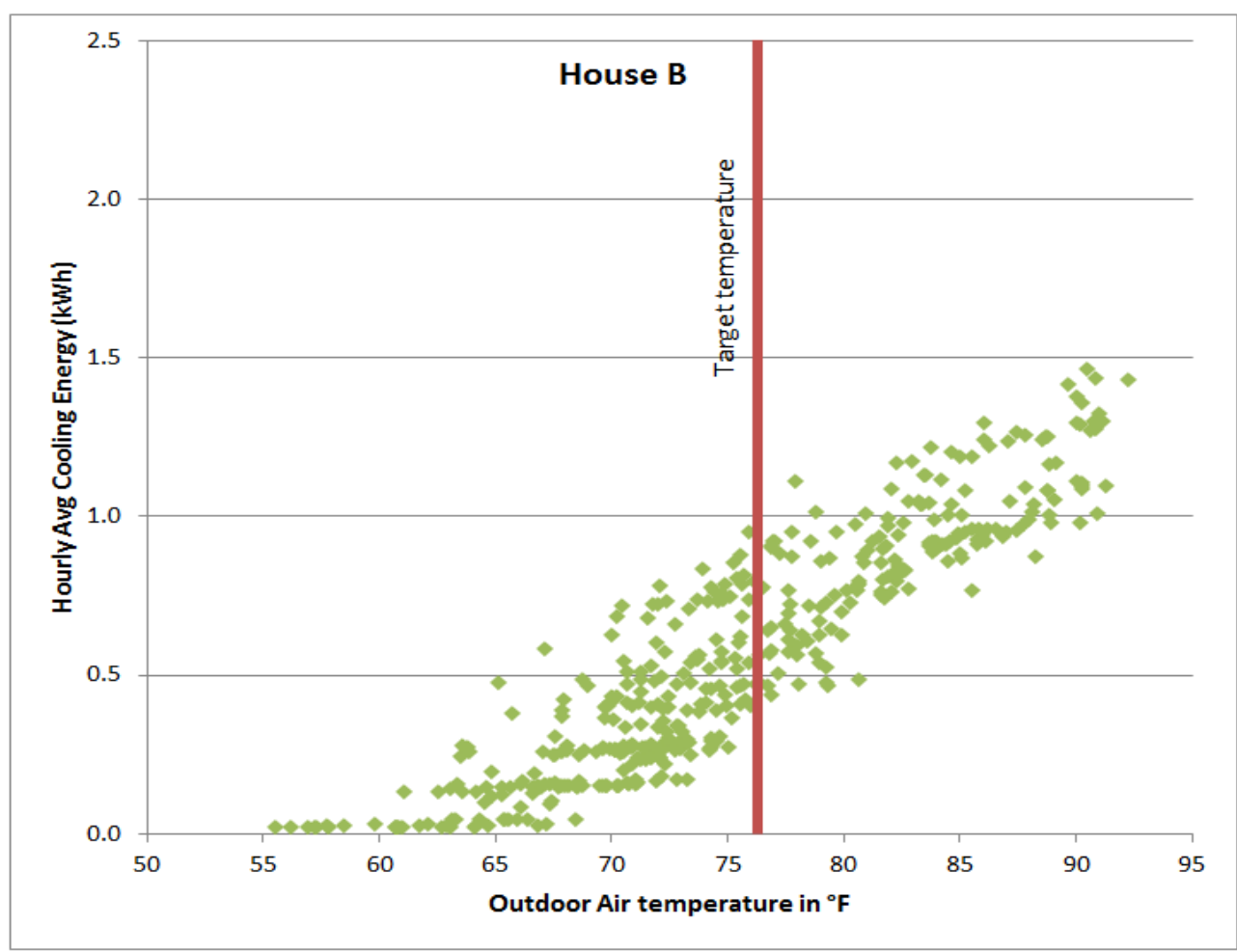

Figure 9. House B cooling energy consumption at various outdoor temperatures (Aug. 29-Sept. 15, 2014)

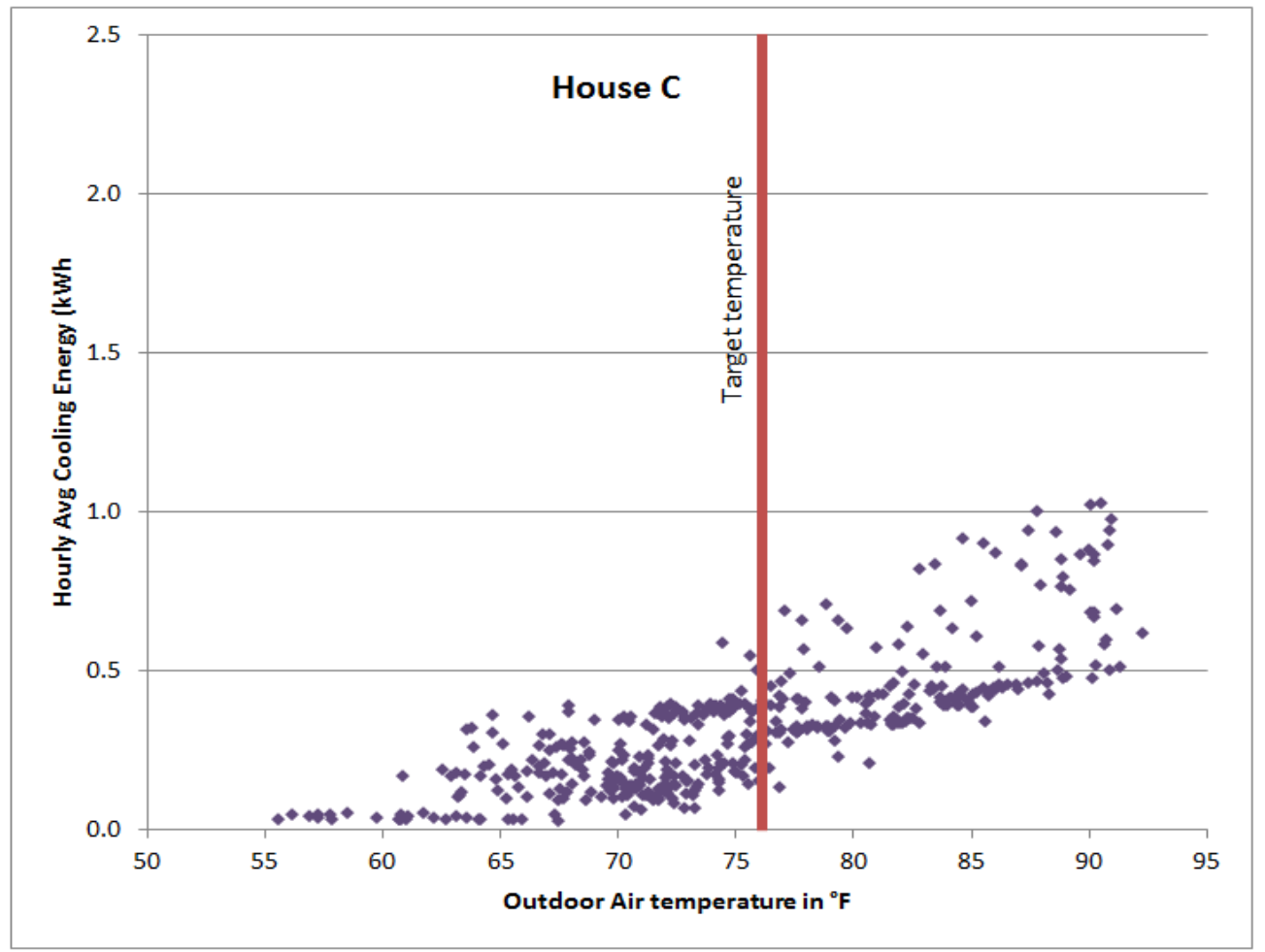

Figure 10. House $C$ cooling energy consumption at various outdoor temperatures (Aug. 29-Sept. 15, 2014) 


\subsubsection{Cooling Season Comfort}

Hourly room temperatures were monitored to provide an indicator of thermal comfort. The graphs below (Figure 11, Figure 12, and Figure 13) show the indoor and outdoor temperatures in each house for a typical week during the cooling season when daily high ambient temperatures reached approximately $90^{\circ} \mathrm{F}$. The horizontal red line indicates the desired room temperature $\left(76^{\circ} \mathrm{F}\right)$. The horizontal dashed lines indicate the upper and lower bounds of the $+/-3^{\circ} \mathrm{F}$ temperature variation in cooling recommended by the Air Conditioning Contractors of America (1997). For the most part, all three houses were successful in maintaining indoor temperatures within this range. In House A, temperatures in the master bedroom and Bedroom 3 spiked the highest. Supply flows in these rooms were lower relative to the room sizes (Table 8). House B had the tightest range, indicating the best overall temperature control. House $\mathrm{C}$ showed the widest temperature fluctuation from one room to another, but only the master bathroom exceeded the upper bounds of the temperature range specified by the Air Conditioning Contractors of America. This room had the longest air pathway from the main living space, and it had southern exposure. The daily temperature fluctuations in the living and dining rooms are the result of the $2^{\circ} \mathrm{F}$ daily setback employed in House C.

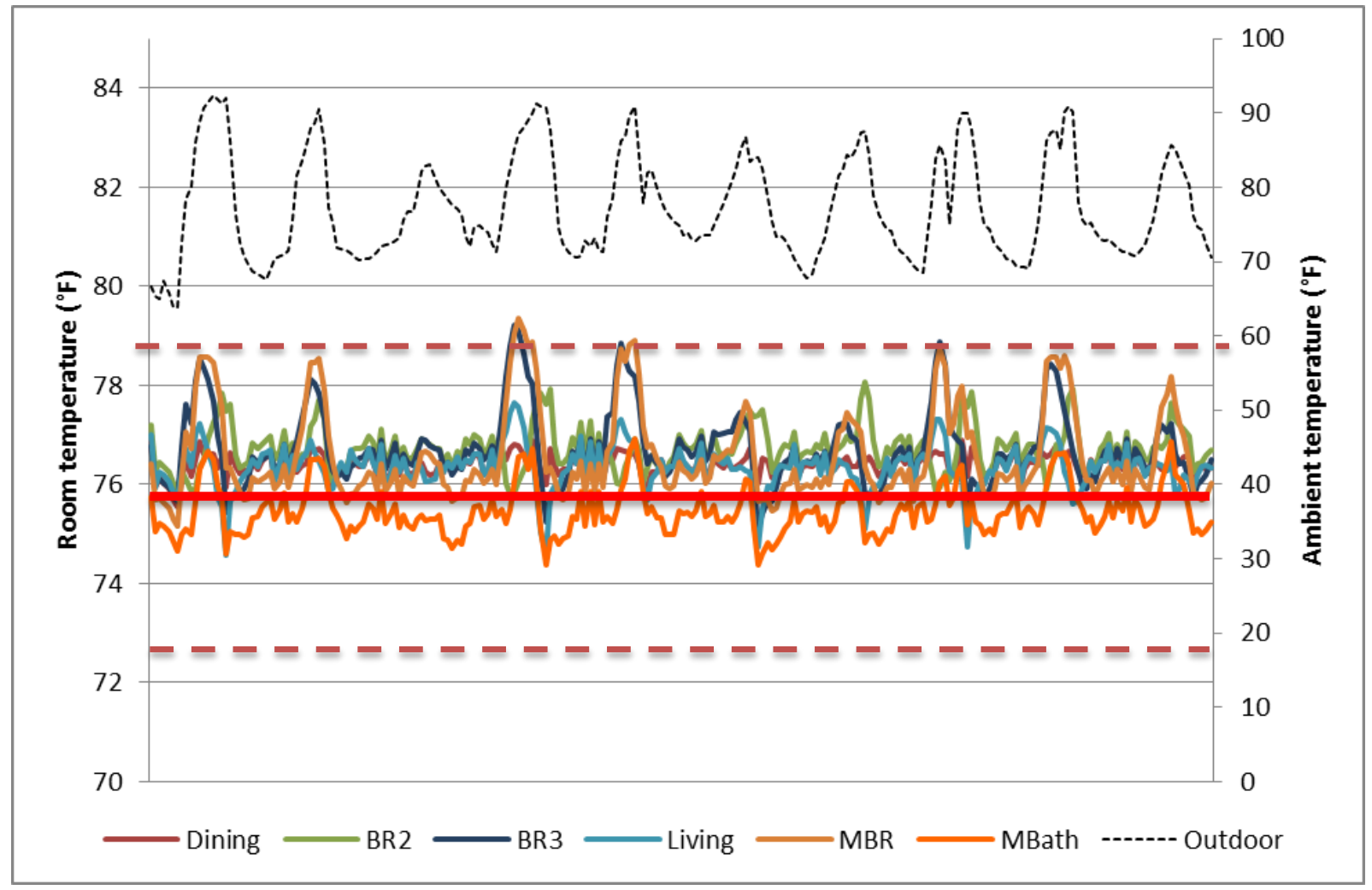

Figure 11. House A room and outdoor temperatures during the typical cooling season

(Aug. 29-Sept. 7, 2014) 


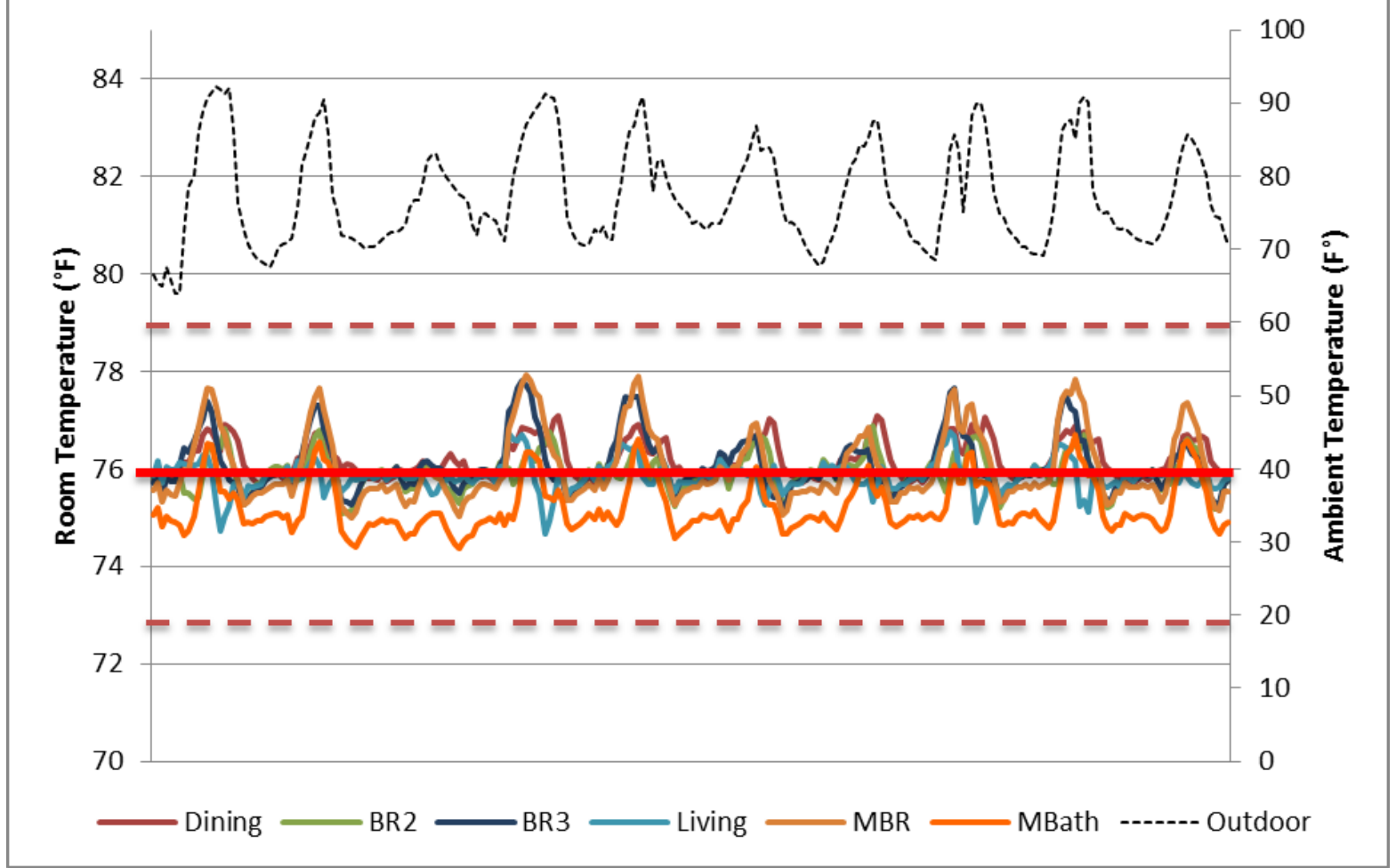

Figure 12. House B room and outdoor temperatures during the typical cooling season (Aug. 29-Sept. 7, 2014)

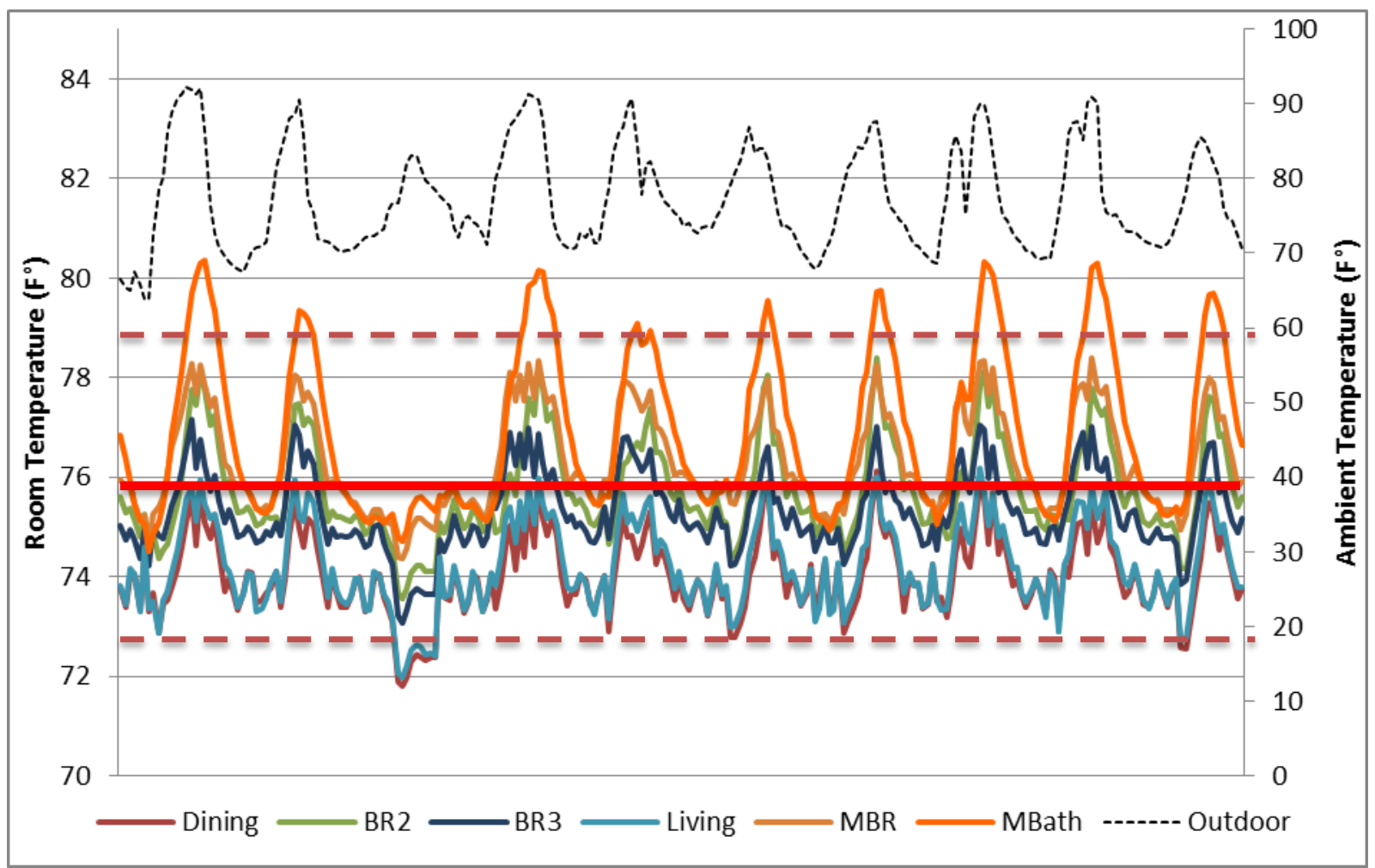

Figure 13. House $C$ room and outdoor temperatures during the typical cooling season (Aug. 29-Sept. 7, 2014) 
Table 8. House A Supply Flows

\begin{tabular}{cccc}
\hline Register & $\begin{array}{c}\text { Measured Supply } \\
\text { Flow }(\mathbf{c f m})\end{array}$ & $\begin{array}{c}\text { Room Size } \\
(\mathbf{s f})\end{array}$ & $\begin{array}{c}\text { Area Normalized } \\
\text { Flow (cfm/sf) }\end{array}$ \\
\hline Bedroom 2(Northwest) & 136 & 142 & 1.0 \\
\hline Bathroom 2 & $\begin{array}{c}\text { Below measurement } \\
\text { threshold }\end{array}$ & 43 & N/A \\
\hline Kitchen & 152 & 159 & 1.0 \\
\hline Dining Room & 140 & 132 & 1.1 \\
\hline Master Bathroom & 151 & 131 & 1.2 \\
\hline Master Bedroom & 126 & 234 & 0.5 \\
\hline Living Room & 116 & 232 & 1.0 \\
\hline Entry & 124 & 137 & 0.8 \\
\hline Bedroom 3 (Northeast) & 109 & 1,210 & 0.87 \\
\hline TOTAL & 1,054 & & \\
\hline
\end{tabular}

\subsubsection{Heating Season HVAC Energy}

Table 9 summarizes the initial heating performance of all three houses in November 2014 with the interior doors open and the window blinds $50 \%$ closed. During this period, when average ambient temperature was $41.3^{\circ} \mathrm{F}$, House $\mathrm{C}$ used $66 \%$ less HVAC energy than House A did and $8 \%$ less than House B did. House B used 63\% less than did House A in heating. Average indoor temperatures were slightly lower than the thermostat set point in House B and House C. Average humidity was similar in all three homes. During this period, House C's fresh air ventilation rate was approximately four times higher than that of the other houses (meeting the ASHRAE Standard 62.2-2010).

Table 9. Heating Statistics (Average Ambient Temperature of $41.3^{\circ} \mathrm{F}$ ) (Nov. 12-17, 2014)

\begin{tabular}{cccc}
\hline & House A & House B & House C \\
\hline Total Heating (Avg. kWh/d) & 48.7 & 18.1 & 16.6 \\
\hline Avg. Indoor Temp. $\left({ }^{\circ} \mathbf{F}\right)$ & 71.3 & 69.9 & 69.5 \\
\hline Heating Desired Temp. $\left({ }^{\circ} \mathbf{F}\right)$ & 71 & 71 & 71 \\
\hline Avg. Relative Humidity $(\%)$ & $28 \%$ & $30 \%$ & $33 \%$ \\
\hline Air Handling Unit Fan Run Time & $22 \%$ & $33 \%$ & $100 \%$ \\
\hline Ventilation-Effective Continuous Rate $(\mathbf{c f m})$ & 10 & 11 & 45 \\
\hline
\end{tabular}

It was observed that bedrooms were not maintaining acceptable temperatures in House C. (See Section 3.3.4 on comfort below.) Therefore, resistance heaters with dedicated thermostats set to 
$69^{\circ} \mathrm{F}$ were added to those rooms. Table 10 summarizes the heating performance of all three houses from January 6-13, 2015, with the addition of resistance heat in House C. Interior doors were open, and window blinds were $50 \%$ closed. During this period, when average ambient temperature was $32.6^{\circ} \mathrm{F}$, House $\mathrm{B}$ and House $\mathrm{C}$ used a similar amount of heating energy and slightly less than half the heating energy of House A.

Average indoor temperatures were close to the thermostat set point in all houses. Average humidity was similar in all three homes. During this period, House C's fresh air ventilation rate was approximately two to three times higher than that of the other houses.

Table 10. Heating Statistics with Resistance Heat in House C Remote Rooms (Average Ambient Temperature of $32.6^{\circ} \mathrm{F}$ ) (Jan. 6-13, 2015)

\begin{tabular}{cccc}
\hline & House A & House B & House C \\
\hline Total Heating (Avg. kWh/d) & 66.6 & 32.3 & 31.8 \\
\hline Avg. Indoor Temp. $\left({ }^{\circ} \mathbf{F}\right)$ & 71.2 & 69.9 & 70.4 \\
\hline Heating Desired Temp. $\left({ }^{\circ} \mathbf{F}\right)$ & 71 & 71 & 71 \\
\hline Avg. Relative Humidity ( $\%)$ & $20 \%$ & $21 \%$ & $22 \%$ \\
\hline Air Handling Unit Fan Run time & $48 \%$ & $47 \%$ & $100 \%$ \\
\hline Ventilation-Effective Continuous Rate (cfm) & 21 & 15 & 45 \\
\hline
\end{tabular}

Figure 14 shows heating power compared to ambient temperature. House B and House $\mathrm{C}$ used less heating energy than did House A at all outdoor temperatures. House B and House C used a similar amount of heating energy, but the trend lines indicate that as temperatures fell House $\mathrm{C}$ used less energy relative to House B. At colder temperatures, the heating system in House B relied more on electric resistance and less on the heat pump, whereas House C's heat pump ran continuously (Figure 14). Figure 15 shows that in House B the backup electric resistance heat turned on when the outdoor air temperature fell below approximately $40^{\circ} \mathrm{F}$, and it increased with decreasing temperatures. During this period, the heat pump showed stable and limited energy consumption. 


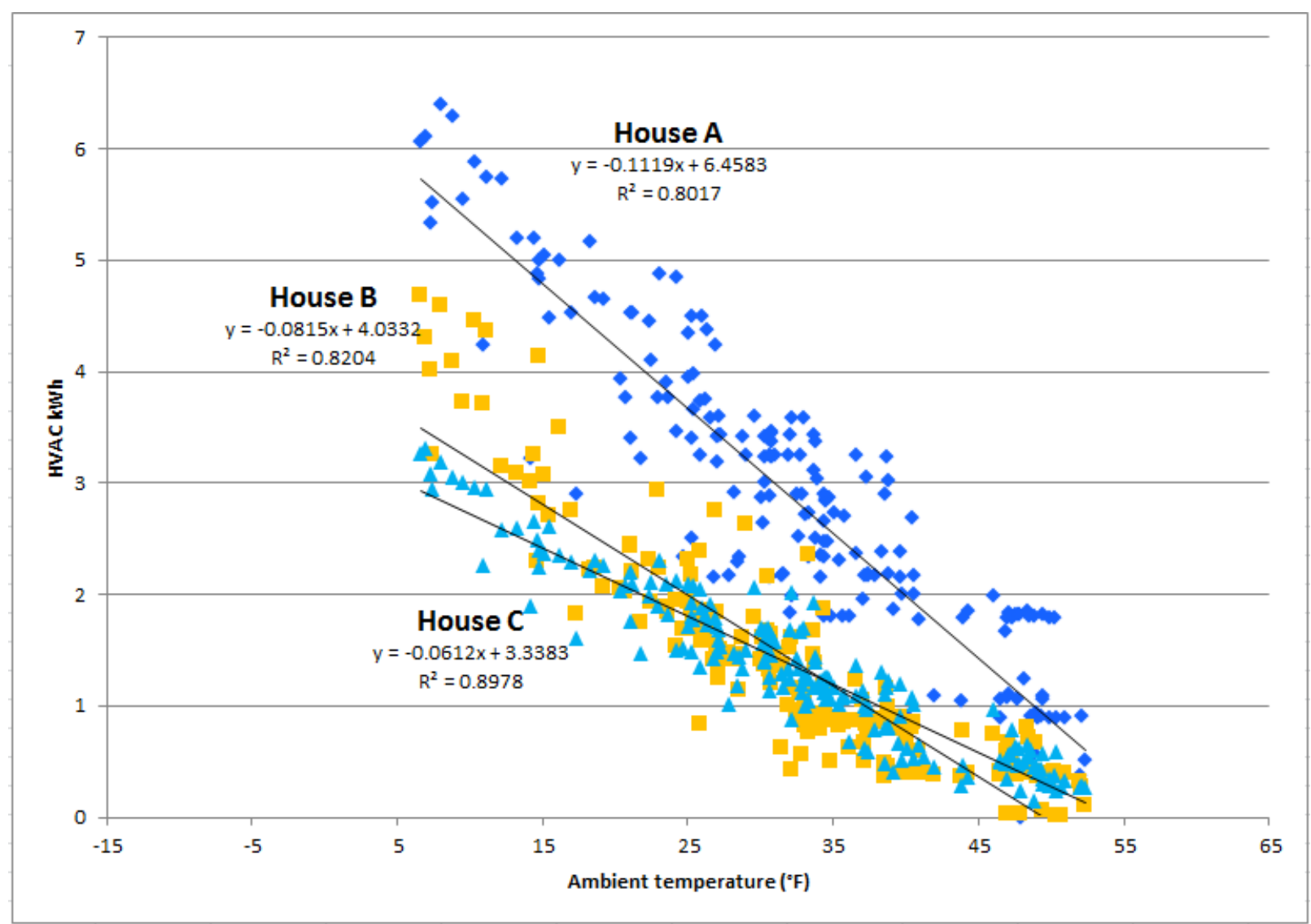

Figure 14. Heating energy compared to outdoor temperature for all three houses (Jan. 6-13, 2015) 


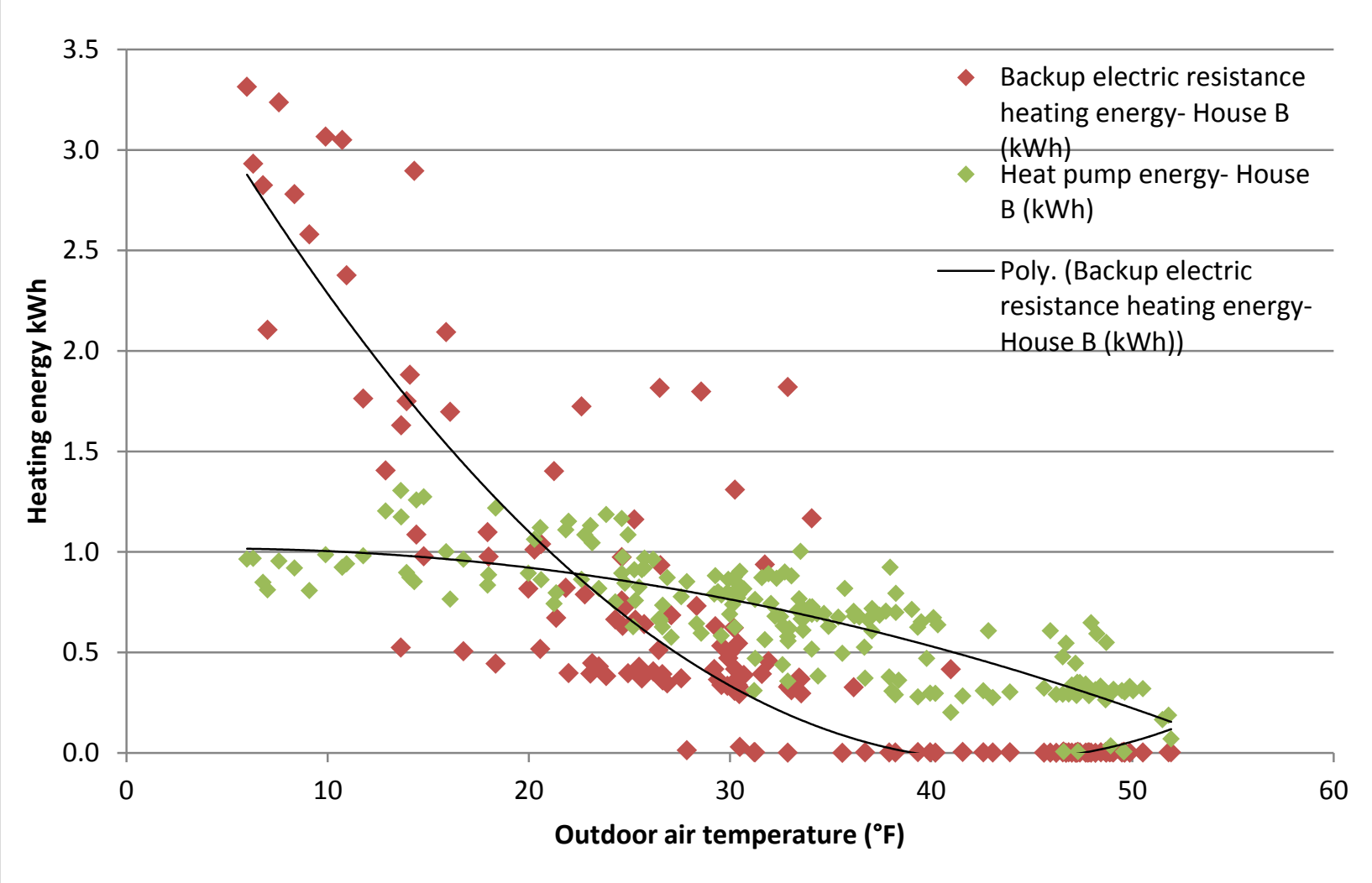

Figure 15. House B backup electric resistance heating energy compared to outdoor air temperature

Figure 16 shows average hourly electrical power used by the three components of the heating system in House $\mathrm{C}$ : the heat pump, the resistance heaters, and the transfer fans. The black line is the ambient temperature $\left({ }^{\circ} \mathrm{F}\right)$. The heat pump and resistance heaters used similar amounts of heating energy, with resistance heating becoming a significant factor when the ambient temperatures fell below approximately $35^{\circ} \mathrm{F}$. During this period, $46 \%$ of the space-conditioning energy use was attributable to the heat pump, $8 \%$ to the fans, and $46 \%$ to the resistance heaters. 


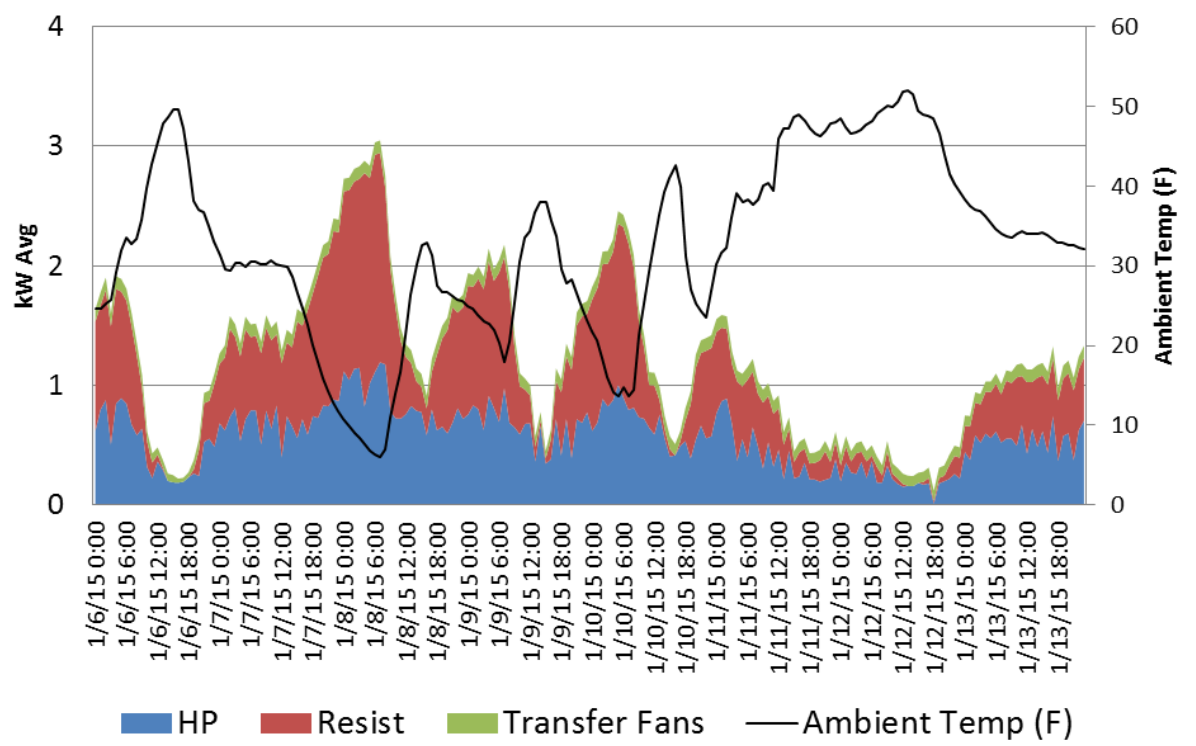

Figure 16. House $C$ heat pump, transfer fan, and resistance heating energy compared to ambient temperature (Jan. 6-13, 2015)

House C's backup resistance heaters helped maintain temperatures in the bedrooms and the master bathroom at $69^{\circ} \mathrm{F}$.

Figure 17 shows that when the outdoor air temperatures were below approximately $40^{\circ} \mathrm{F}$, the resistance heat consumption started climbing, and it surpassed the heat pump energy consumption when the ambient temperatures fell below approximately $25^{\circ} \mathrm{F}$.

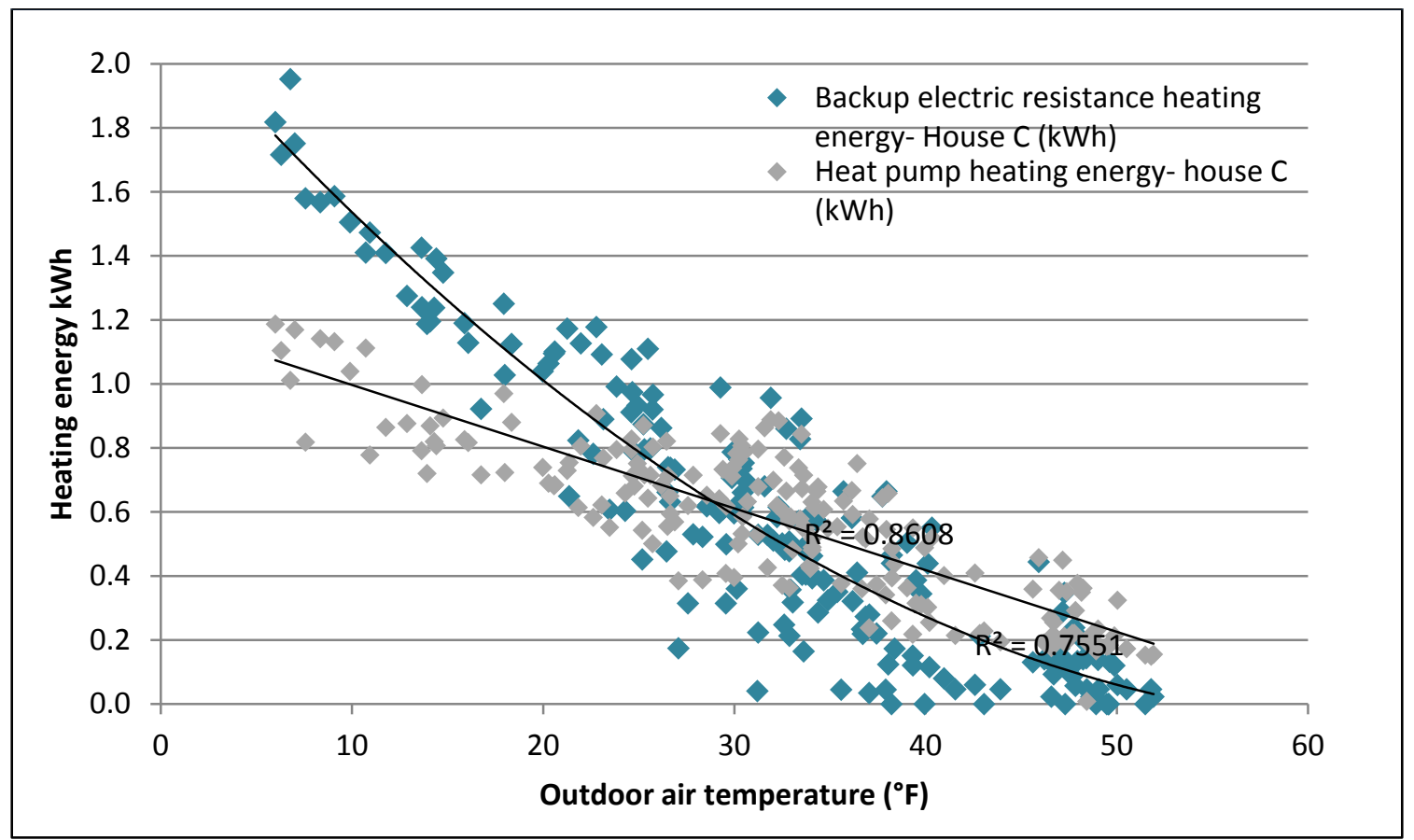

Figure 17. House $C$ resistance heating energy compared to ambient temperature $($ Jan. 6-13, 2015) 


\subsubsection{Heating Season Comfort}

As discussed above, an analysis of the indoor temperatures in House $\mathrm{C}$ revealed that the remote rooms were not maintaining acceptable temperatures (Figure 18). In particular, the master bathroom and master bedroom were falling well below the Air Conditioning Contractors of America acceptable heating variation from the set point limit $\left(+/-2^{\circ} \mathrm{F}\right.$ from the set point in heating) when the outdoor temperatures fell below approximately $50^{\circ} \mathrm{F}$. It was therefore decided to add electric resistance heat to the bedrooms and master bathroom controlled on independent thermostats to maintain at least $69^{\circ} \mathrm{F}$ in those rooms.

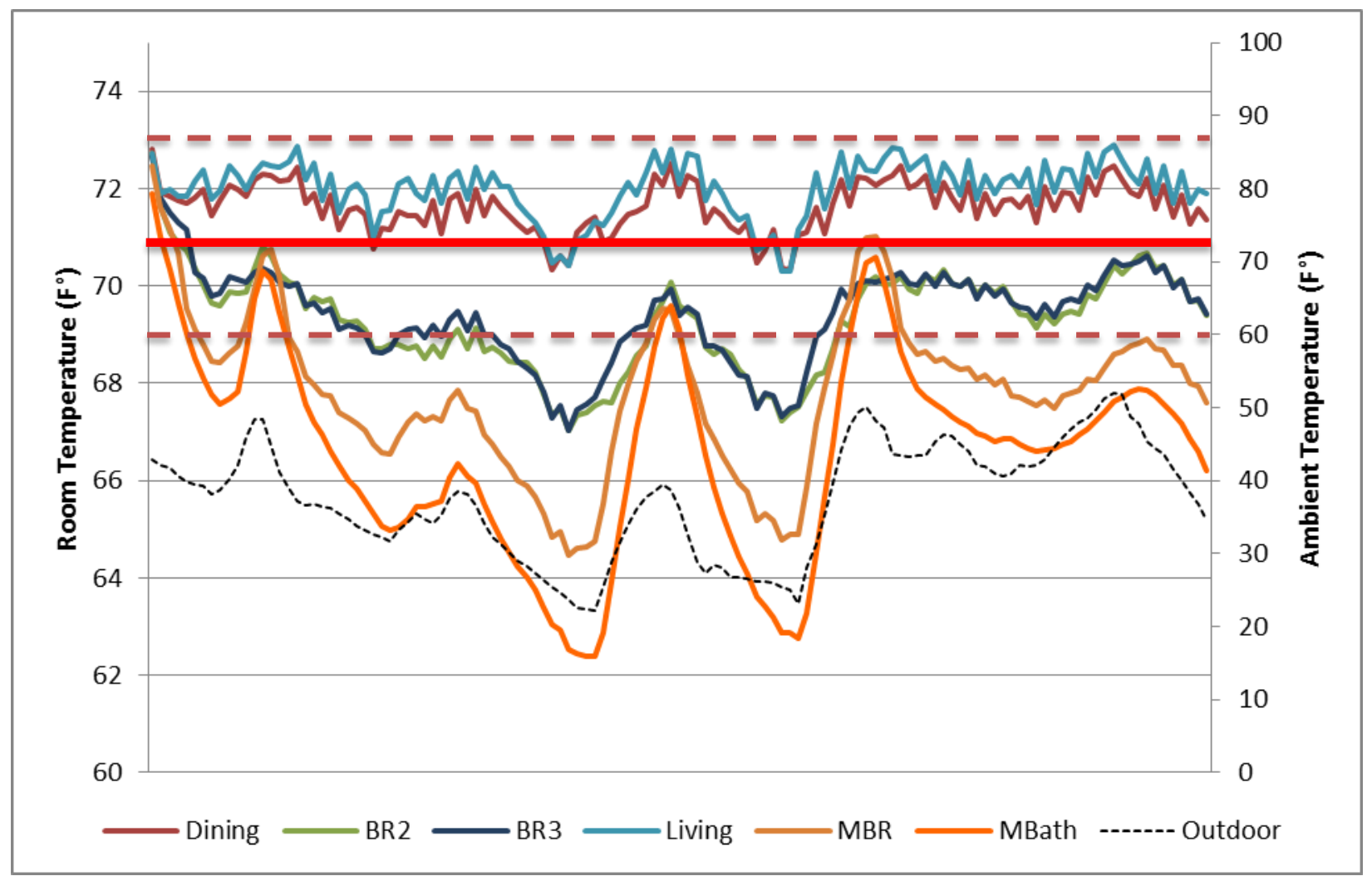

Figure 18. House $\mathrm{C}$ room and outdoor temperatures for the initial heating season analysis

(Nov. 12-17, 2014) 
After the resistance heat was activated, the bedrooms still remained cooler than the main space (at or above the $69^{\circ} \mathrm{F}$ electric heat set point); however, the comfort metrics met the Air Conditioning Contractors of America guidelines (Figure 19).

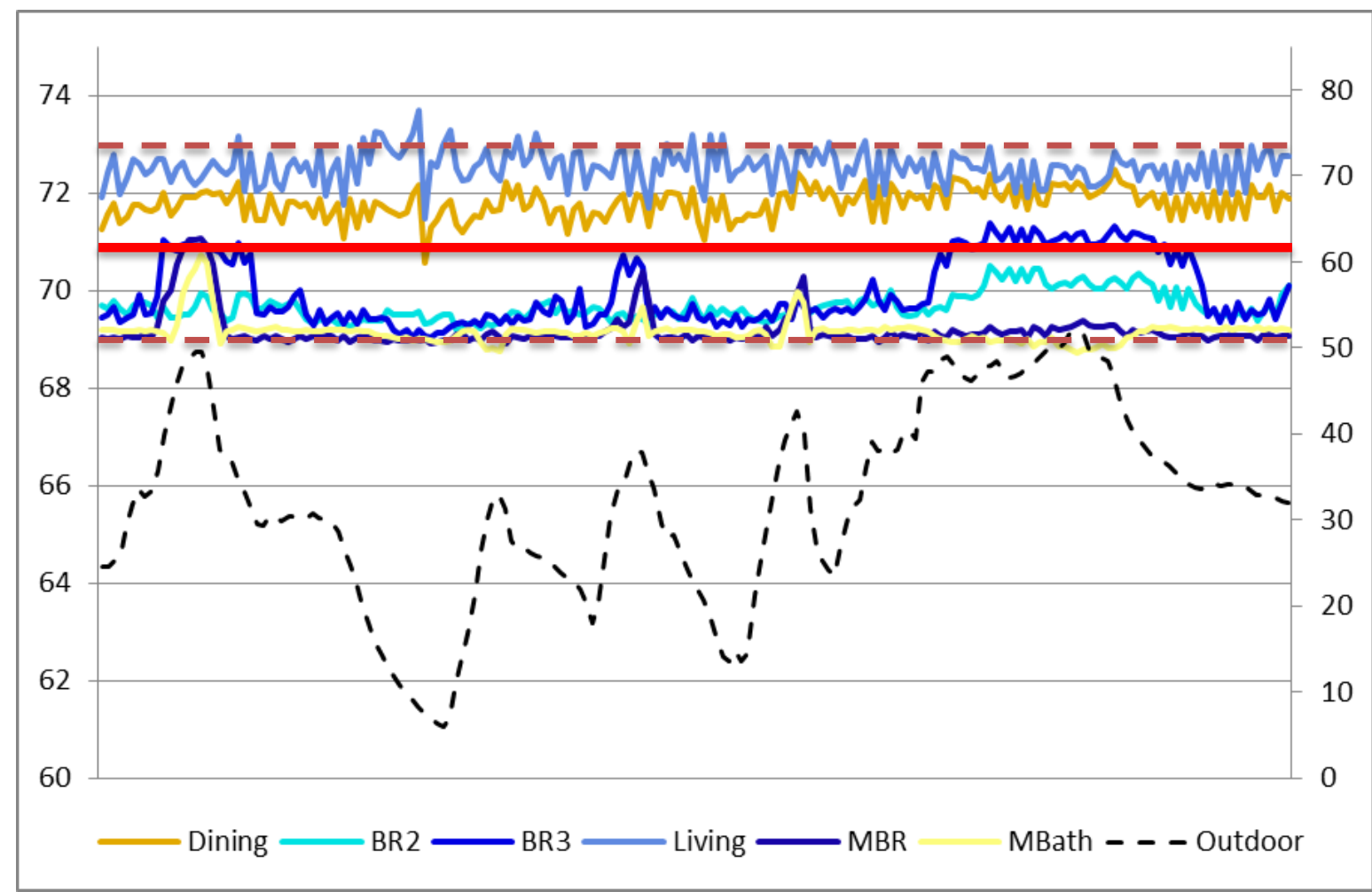

Figure 19. House $\mathrm{C}$ room and outdoor temperatures with resistance heat in remote rooms (Jan. 6-13, 2015)

For comparison purposes, the room temperatures in House A and House B are shown in Figure 20 and Figure 21, respectively. Bedroom 2, Bedroom 3, and sometimes the master bathroom struggled (sometimes unsuccessfully) to maintain $69^{\circ} \mathrm{F}$ in both House A and House B. 


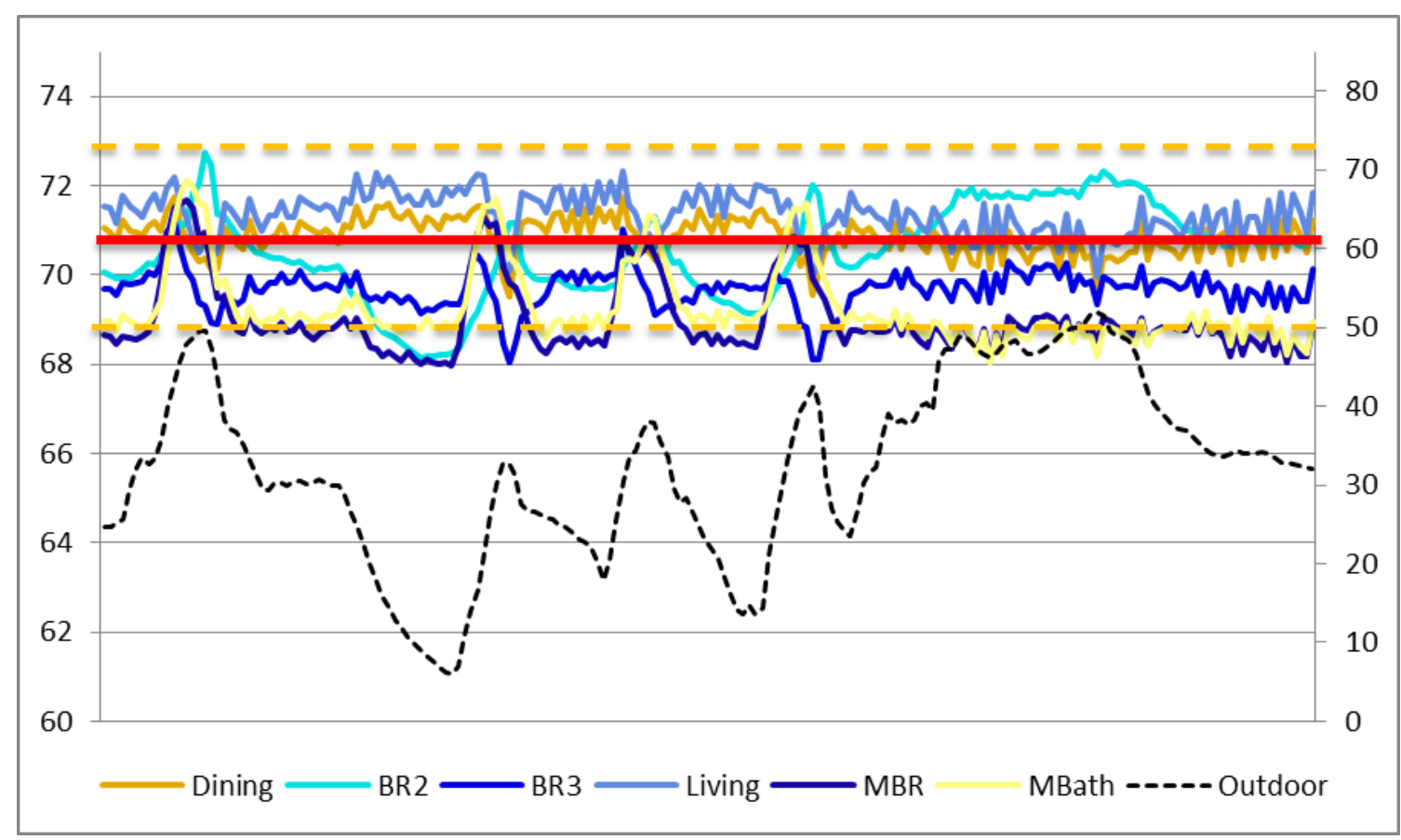

Figure 20. House A room and outdoor temperatures (Jan. 6-13, 2015)

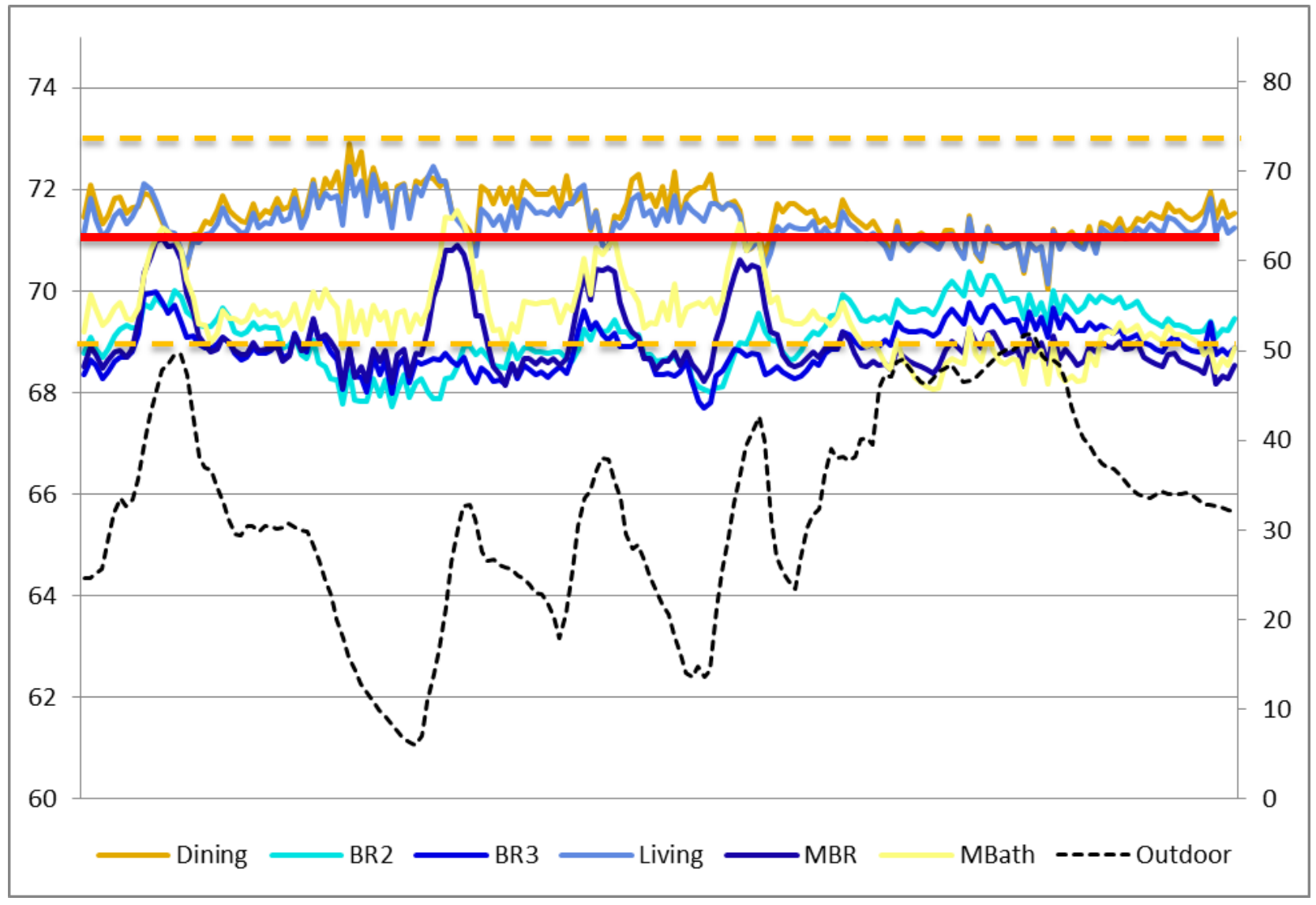

Figure 21. House B room and outdoor temperatures (Jan. 6-13, 2015) 


\subsubsection{Whole-House Ventilation}

Whole-house ventilation in House A and House B is achieved through the air handling unit, as is typical for manufactured homes. A fresh-air intake at the roof is connected via a 4-in-diameter flexible duct to the return side of the air handling unit. There is no mechanical damper.

In House $\mathrm{C}$, a continuously operating exhaust fan in the main living space provides ventilation in accordance with ASHRAE Standard 62.2-2010. This fan was initially planned for the master bathroom to help draw conditioned air from the living space to the master suite, but code required it to be in a central location.

Table 11 compares the effective ventilation rates in each house to the requirements of HUD (2010) and ASHRAE Standard 62.2-2010. The rates in House A and House B were lower than the HUD recommendation of $0.035 \mathrm{ft}^{3}$ per $\mathrm{ft}^{2}$, and all three houses were lower than the HUD minimum of $50 \mathrm{cfm}$.

Table 11. Effective Ventilation Rates

\begin{tabular}{ccc}
\hline \multirow{2}{*}{ House } & \multicolumn{2}{c}{$\begin{array}{c}\text { Whole-House Ventilation Flow } \\
\text { (cfm) }\end{array}$} \\
\cline { 2 - 3 } & Measured & Required $^{\mathrm{a}}$ \\
A & 22 & 50 \\
B & 13 & 50 \\
C & 45 & 50 \\
\hline
\end{tabular}

${ }^{a}$ The required whole-house ventilation rate should be $0.035 \mathrm{ft}^{3}$ per square foot of the conditioned space or a minimum of $50 \mathrm{cfm}$. Conditioned area $=1,210 \mathrm{ft}^{2}$.

\subsubsection{Moisture Measurements}

One risk of adding exterior foam insulation to the walls in House $\mathrm{C}$ was that the reduced vapor permeability of the foam sheathing (extruded polystyrene insulation) could lead to higher moisture content in the wall cavity. To explore the potential for condensation within the wall cavities with exterior foam sheathing, air temperature and relative humidity in a cavity between the sheathing and interior fiberglass insulation on a north wall was measured to estimate the condensation potential in the cavity. A temperature and relative-humidity sensor was installed approximately $2.5 \mathrm{in}$. above the floor inside the cavity. The moisture content of a wood stud in the cavity was also measured at the same location using an Omnisense S900-1 moisture content sensor (Figure 22). 


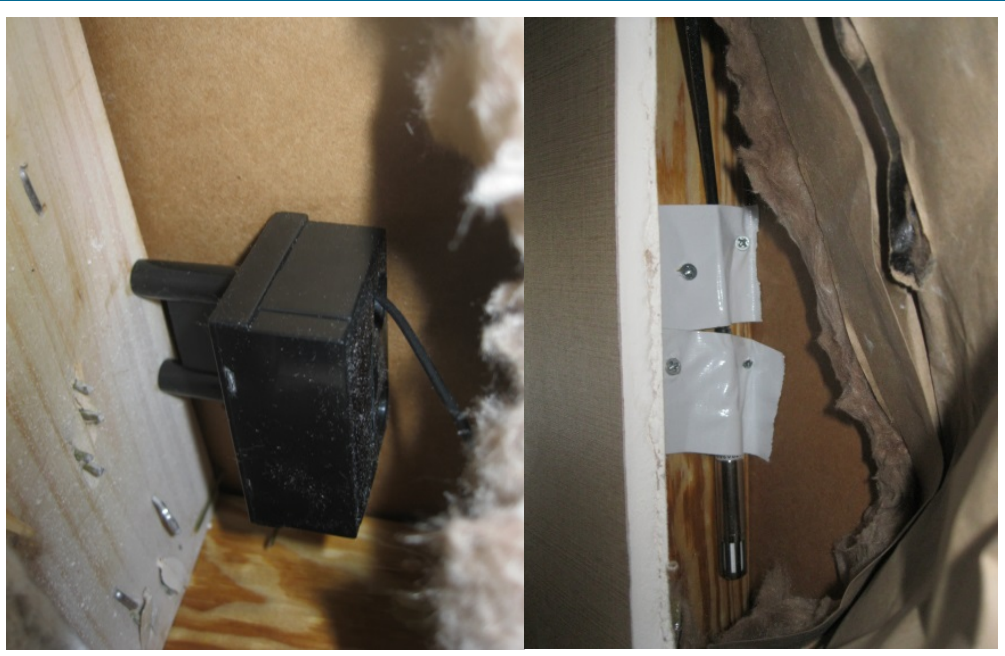

Figure 22. Moisture content and temperature/relative humidity sensors mounted in wall cavity

Figure 23, Figure 24, and Table 12 show the data from the moisture content sensors in the wall cavities in House B and House C. Wood moisture content was slightly higher in House C, but it was still well within the safe limits of 19\% (Forest Products Laboratory 2015). Additionally, the House $\mathrm{C}$ wall cavity temperature was moderated by the exterior insulation, which resulted in a minimum temperature that was $5.5^{\circ} \mathrm{F}$ higher than it was in House $\mathrm{B}$, mitigating condensation risk.

House C's moisture content tended to be somewhat higher in the summer, consistent with higher overall humidity in the house. House B had slightly higher readings in the winter. Note that the houses were unoccupied, and no moisture was added to simulate latent loads. Because the homes were newly constructed in the plant, wood was not subject to wetting, but it could have had residual natural moisture. Seasonal data seems to follow the expected trend-higher in the summer and lower in the winter. Note that the vinyl-covered wallboard used in all three homes has been associated with moisture problems in warm, humid climates (Moyer et al. 2001). 


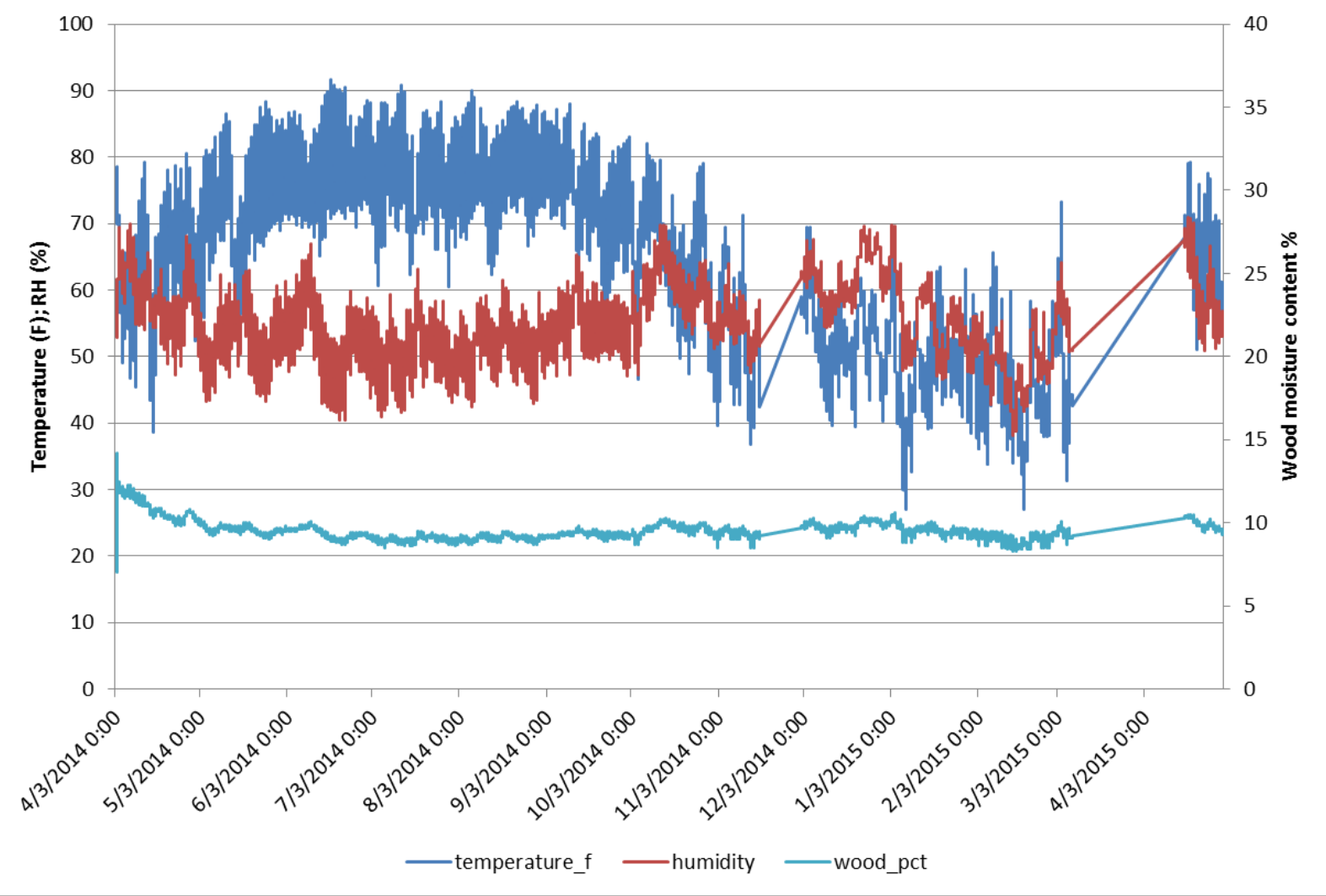

Figure 23. House B wall cavity conditions and wood moisture content (April 2014-April 2015)

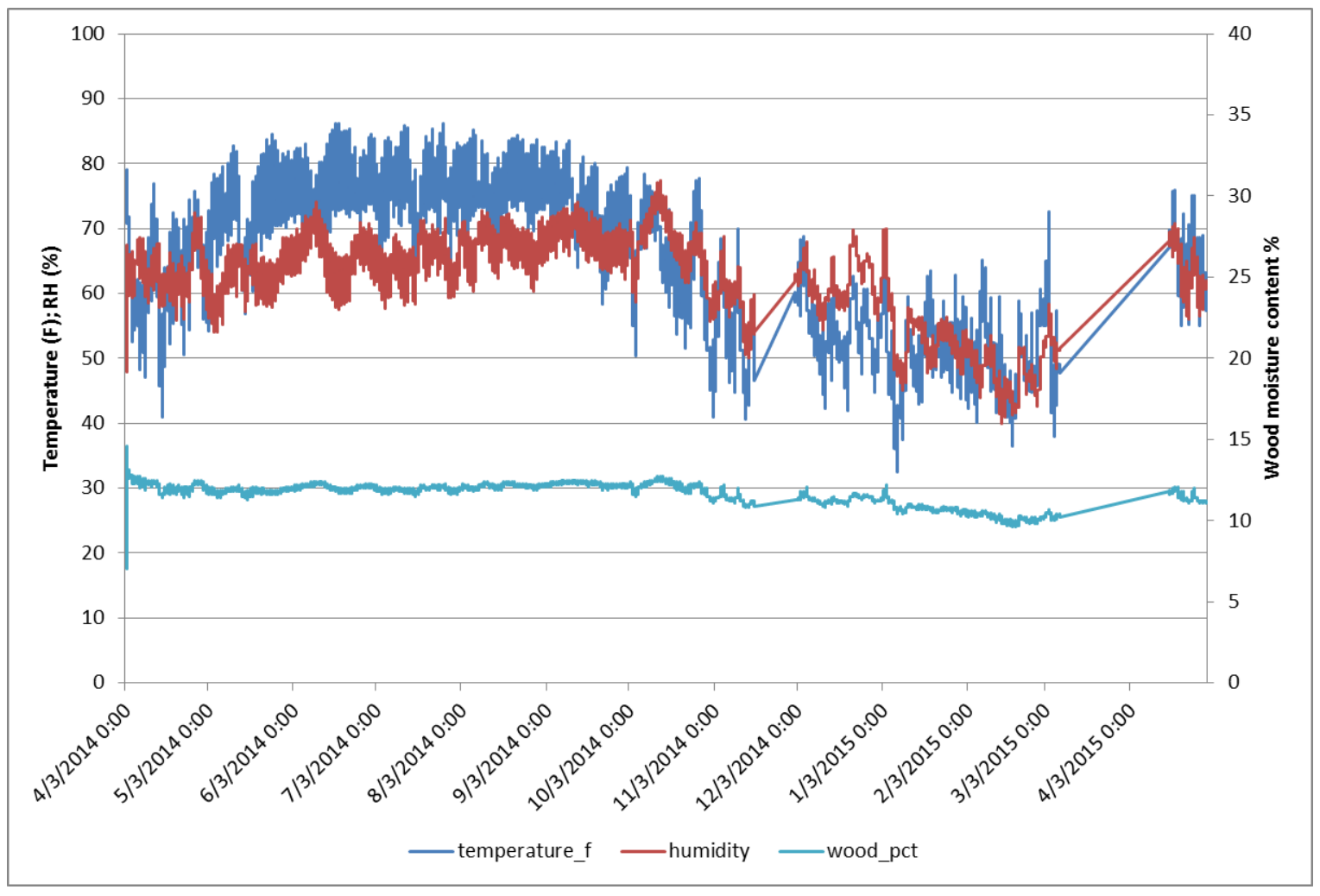

Figure 24. House C wall cavity conditions and wood moisture content (April 2014-April 2015) 
Table 12. Wall Cavity Maximum, Minimum, and Average Conditions (April 2014-April 2015)

\begin{tabular}{cccccc}
\hline House & & Temp. $\left({ }^{\circ} \mathbf{F}\right)$ & $\begin{array}{c}\text { Humidity } \\
(\mathbf{\%})\end{array}$ & $\begin{array}{c}\text { Wood Moisture } \\
\text { Content }(\%)\end{array}$ & $\begin{array}{c}\text { Dew Point } \\
\left({ }^{\circ} \mathbf{F}\right)\end{array}$ \\
\hline \multirow{2}{*}{ B } & Maximum & 91.6 & 71.0 & 14.2 & 67.2 \\
& Minimum & 27.0 & 38.2 & 7.0 & 7.9 \\
& Avg. & 64.8 & 54.7 & 9.5 & 48.0 \\
\hline \multirow{2}{*}{$\mathbf{C}$} & Maximum & 86.2 & 77.4 & 14.6 & 73.3 \\
& Minimum & 32.5 & 40.0 & 7.0 & 15.9 \\
& Avg. & 65.2 & 62.2 & 11.6 & 52.1 \\
\hline
\end{tabular}

\subsubsection{Peak Electric Demand}

Peak electric demand is calculated by the utility serving Russellville (Tennessee Valley Authority) as the single half-hour period with highest average power (kW) draw in the month. The coincident peak hours of the Tennessee Valley Authority system are as follows:

- Winter: December-March, 6:00 a.m.-8:00 a.m.

- Summer: June-September, 2:00 p.m.-5:00 p.m.

Figure 25 shows the peak demand for the three houses using the criteria from the Tennessee Valley Authority. Some data is missing from February and March because experiments run during those months interfered with normal house operation. Peak demand in House C was significantly lower than the other two houses during all months of the year. The heat pump in House $\mathrm{C}$ operated nearly continuously, so there was much less variation in power draw. House B had somewhat lower peaks than did House A during most months, but some winter peaks were similar, indicating that House B's peak occurred when the heat pump was not running and the house was relying solely on electric resistance backup. On average, during the peak hours of the Tennessee Valley Authority system, House B had an 18\% lower peak demand than did House A, and House $\mathrm{C}$ had a $69 \%$ lower peak demand than did House A.

Interestingly, when broadening the range of hours to show peaks for any time of day, House B had higher winter peak demand than did House A during most months (Figure 26). 


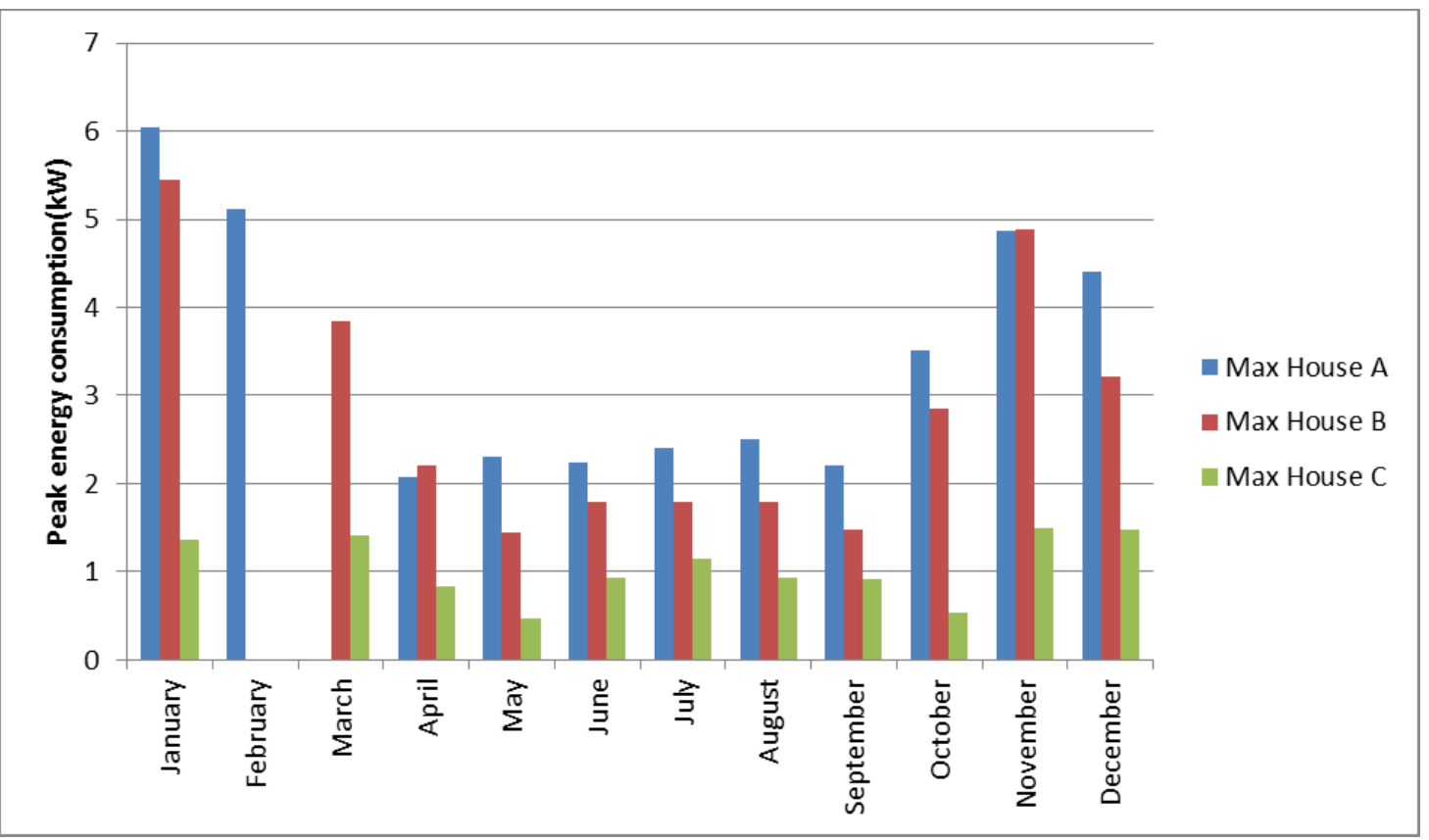

Figure 25. Monthly peak demand during coincident peak hours of the Tennessee Valley Authority system

Table 13. Summary of Average Peak Demand Reduction During Peak Hours of the Tennessee Valley Authority System

\begin{tabular}{ccc}
\hline House & $\begin{array}{c}\text { Avg. Monthly Peak Demand } \\
\text { During Peak Hours }\end{array}$ & $\begin{array}{c}\text { Avg. Demand Reduction } \\
\text { Compared to House A }\end{array}$ \\
\hline A & 3.1 & N/A \\
B & 2.6 & $18 \%$ \\
C & 1.0 & $69 \%$ \\
\hline
\end{tabular}




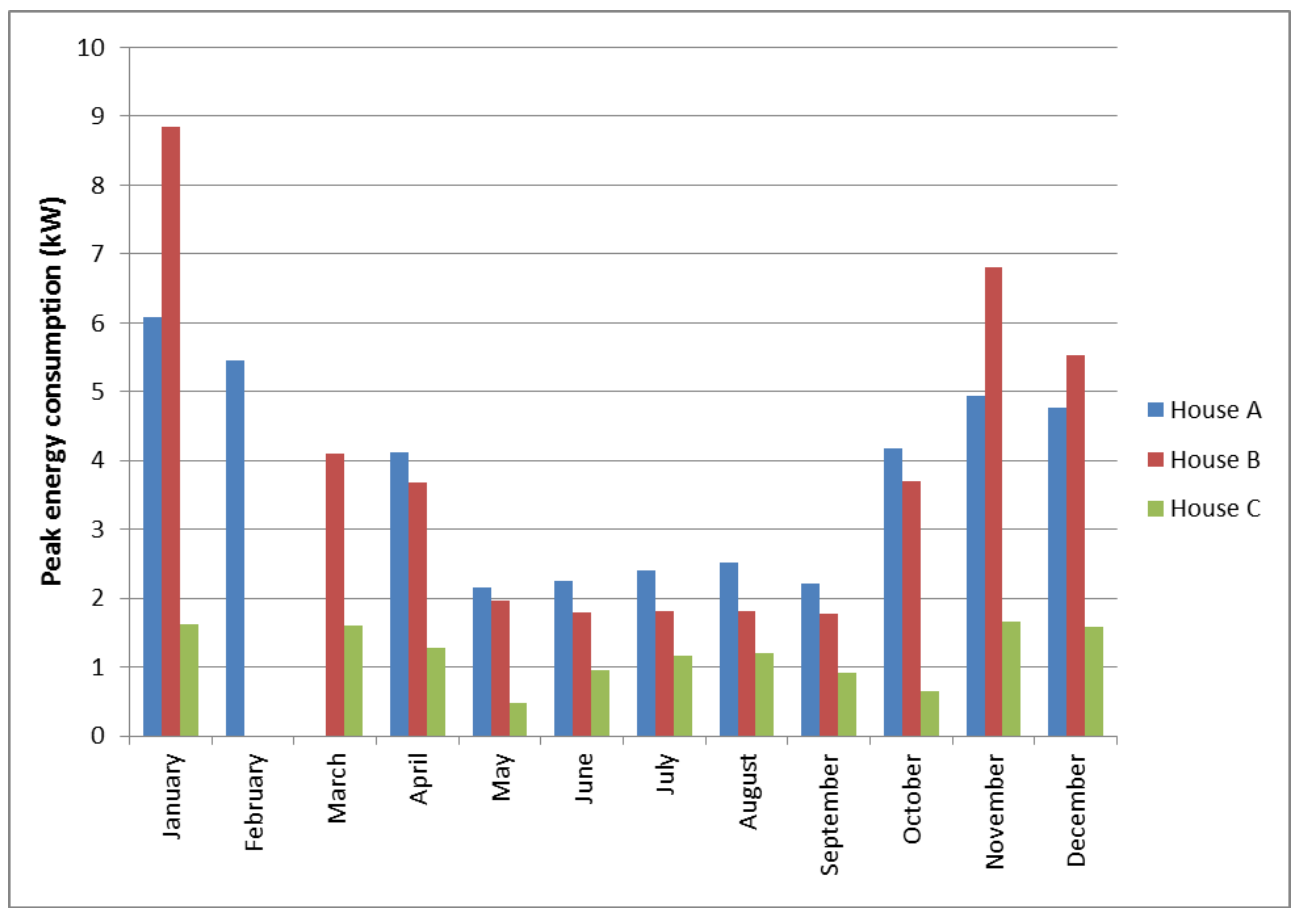

Figure 26. Monthly peak demand during all hours of the day

\subsubsection{Co-heat and Tracer Gas Testing}

Short-term co-heat testing in cold weather using portable electric resistance space heaters was conducted in all three houses to measure whole-house heat loss. The test data was used to obtain envelope U-value information that was used to tune the simulation parameters. During the test, six portable heaters (one in each bedroom, one in the master bathroom, one in the living room, and one in the kitchen) were used to maintain $70^{\circ} \mathrm{F}$ throughout the duration of the test. Other heating equipment was switched off. Temperature sensors were used to turn the heaters on and off through the Campbell Scientific data loggers. Tracer gas decay testing was conducted simultaneously with the co-heat testing to differentiate convective from conductive heat loss.

These tests were conducted during four days in December 2014 (December 8-11). Co-heat tests were run in each house on three nights. Tracer gas measurements were made in conjunction with some of the co-heat tests (Table 14). 
Table 14. Testing Schedule

\begin{tabular}{cccc}
\hline & A & B & C \\
\hline Dec. 8-9 & Co-heat & Co-heat & Co-heat \\
Dec. 9-10 & Co-heat & $\begin{array}{c}\text { Co-heat } \\
\text { Tracer gas }\end{array}$ & $\begin{array}{c}\text { Co-heat } \\
\text { Tracer gas }\end{array}$ \\
Dec. 10-11 & $\begin{array}{c}\text { Co-heat } \\
\text { Tracer gas }\end{array}$ & Co-heat & $\begin{array}{c}\text { Co-heat } \\
\text { Tracer gas }\end{array}$ \\
\hline Dec. 11-12 & Tracer gas & Tracer gas & \\
\hline
\end{tabular}

\subsubsection{Co-Heat Testing}

The co-heat test procedure was as follows:

1. The continuous exhaust fan in House $\mathrm{C}$ was turned off.

2. Heating systems in all houses were turned off.

3. Electric space heaters, controlled by the data logger based on each room's indoor temperature, were used to maintain constant indoor temperature overnight in all rooms. Each room had its own heater and temperature sensor.

4. For two tests in each house, a simultaneous tracer gas test (see procedure below) was conducted to measure the infiltration rate during the co-heat testing period.

5. Fans were used to evenly distribute the heat and the tracer gas.

6. The energy consumed by the heaters, fans, and data collection equipment was measured continuously.

7. The heat loss of the building, inclusive of infiltration, was calculated via the following equation:

Where:

$$
U A=I G /(\text { Tout }- \text { Tin })
$$

$$
\begin{aligned}
& \mathrm{UA}=\text { Heat loss in } \mathrm{kW} \text { per degree } \mathrm{C} \\
& \mathrm{IG}=\text { Total internal heat gain in } \mathrm{kW} \\
& \text { Tout }=\text { Ambient outdoor temperature }\left({ }^{\circ} \mathrm{C}\right) \\
& \text { Tin }=\text { Average indoor temperature }\left({ }^{\circ} \mathrm{C}\right) .
\end{aligned}
$$

\subsubsection{Tracer Gas Testing}

Infiltration was measured in all three homes utilizing tracer gas. The objectives of the tracer gas testing were to determine infiltration levels in all three houses for calibrating models and quantifying the effectiveness of the ventilation systems. Tracer gas testing was conducted simultaneously with co-heat testing so that envelope infiltration losses could be separately accounted for in the resulting heat loss estimates. The tracer gas test procedure was as follows: 
1. The houses were set up per the co-heat procedure above on December 9-10 and December 10-11. For the December 11-12 test, the space-conditioning systems were on.

2. Air sampling tubes were run to each room and connected to a Brüel and Kjær Model 1302 Multi-Gas Monitor System. A Brüel and Kjær 1303 Multipoint Sampler was used in House $\mathrm{C}$ to separately measure the sulfur hexafluoride tracer gas concentration in each room (Figure 27). In House A and House B, the room sample tubes were connected to a common manifold.

3. Sulfur hexafluoride was released into the space to an approximate concentration of 3-4 ppm.

4. The tracer gas monitoring systems measured the sulfur hexafluoride concentration at 5min intervals.

5. The decay rate of sulfur hexafluoride was converted into a natural air change rate via the following equation:

$$
\text { ACHnatural }=\ln (C 1 / C 2)
$$

Where:

ACHnatural $=$ natural air change rate per hour for hour $\mathrm{n}$

$\ln =$ natural logarithm

$\mathrm{Cl}=$ Average sulfur hexafluoride concentration in parts per million for hour $\mathrm{n}-1$

$\mathrm{C} 2$ = Average sulfur hexafluoride concentration in parts per million for hour $\mathrm{n}$.
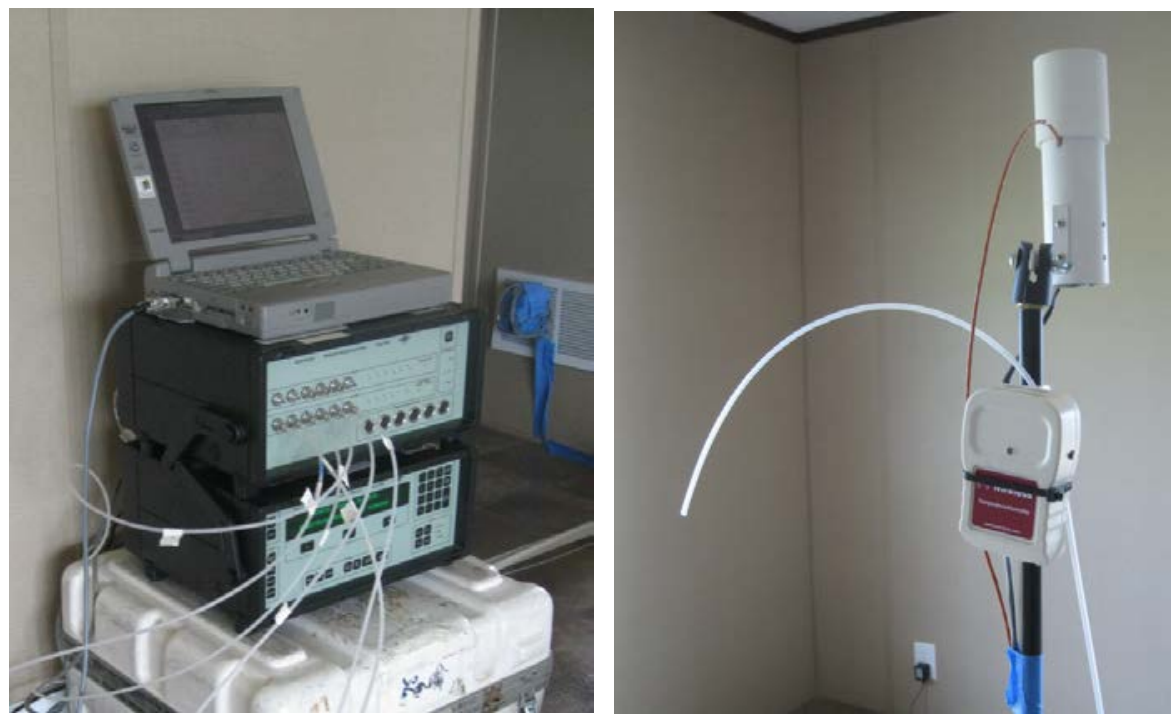

Figure 27. Tracer gas sampling equipment and sampling tube

The results of the tracer gas testing are summarized in Table 15 along with a comparison to the blower door testing and the natural air change rates predicted from the blower door test results using the Alberta Air Infiltration Model (AIM-2) incorporated into BEopt V 2.3.0.2 (Walker and Wilson 1998). The tracer gas testing data are provided in Appendix E. Results for the multiple 
tests in House B and House $\mathrm{C}$ are consistent from one test to another, but they are higher than the annual average AIM-2 predictions.

Table 15. Tracer Gas Test Results Summary

\begin{tabular}{|c|c|c|c|}
\hline & House A & House B & House C \\
\hline Dec. 8--9 & & 0.22 & 0.14 \\
\hline Dec. 9-10 & & 0.22 & 0.14 \\
\hline Dec. $10-11$ & 0.25 & 0.24 & \\
\hline Overall Avg. & 0.25 & 0.23 & 0.14 \\
\hline $\begin{array}{c}\text { Blower Door Air Change Rate } \\
\text { (ACH50) }\end{array}$ & 4.7 & 4.6 & 3.8 \\
\hline $\begin{array}{l}\text { Air Change Rate Extrapolated } \\
\text { from Blower Door Test }{ }^{\mathrm{a}}\end{array}$ & $\begin{array}{c}0.13 \\
\text { (annually) }\end{array}$ & $\begin{array}{c}0.12 \\
\text { (annually) }\end{array}$ & $\begin{array}{c}0.10 \\
\text { (annually) }\end{array}$ \\
\hline
\end{tabular}

One set of tracer gas tests was conducted with space-conditioning and ventilation systems operating (Table 16). The continuous exhaust ventilation fan in House $\mathrm{C}$ ( $45 \mathrm{cfm}$ ) resulted in a higher air change rate than in House A and House B. The air change rate in House B was higher with systems operating than with systems off. However, there was no measured increase in the House A air change rate when the system was operating compared to when the system was off.

Table 16. Tracer Gas Test Results Summary-With Systems Operating

\begin{tabular}{lccc}
\hline & $\begin{array}{c}\text { House A } \\
\text { Dec. 11-12 }\end{array}$ & $\begin{array}{c}\text { House B } \\
\text { Dec. 11-12 }\end{array}$ & $\begin{array}{c}\text { House C } \\
\text { Dec. 8, 8-10 a.m. }\end{array}$ \\
\hline $\begin{array}{c}\text { Estimated Continuous } \\
\text { Effective Mechanical } \\
\text { Ventilation Rate Based on } \\
\text { Commissioning Tests and Air } \\
\text { Handling Unit/Exhaust Fan } \\
\quad \text { Run Time (cfm) }\end{array}$ & 22 & 13 & 45 \\
$\begin{array}{c}\text { ACH Natural from Tracer Gas } \\
\text { Test }\end{array}$ & 0.25 & 0.27 & 0.28 \\
\hline $\begin{array}{c}\text { ACH Natural from Tracer Gas } \\
\text { Tests Converted to cfm }\end{array}$ & $40 \mathrm{cfm}$ & $44 \mathrm{cfm}$ & $45 \mathrm{cfm}$ \\
\hline
\end{tabular}

The results of the daily co-heat testing are summarized in Table 17. 
Table 17. Co-heat Test Results Summary (Btu/h/ $\left.{ }^{\circ} \mathrm{F}\right)$

\begin{tabular}{cccc}
\hline Test & A & B & C \\
\hline Dec. 10 & 326 & 250 & 202 \\
Dec. 11 & 299 & 237 & 212 \\
\hline
\end{tabular}

The results of the co-heat testing are summarized in Table 18 along with a comparison to the UA value (heat loss over the entire surface area) predicted by the house designs. The co-heat testing data are provided in Appendix G. The results are in reasonable agreement.

Table 18. Co-Heat Test Results Summary Adjusted for Infiltration

\begin{tabular}{cccccc}
\hline House & $\begin{array}{c}\text { Co-Heat } \\
\text { Results (Incl. } \\
\text { Infiltration } \\
\text { Losses) } \\
\left(\mathbf{B t u} / \mathbf{h} /{ }^{\circ} \mathbf{F}\right)\end{array}$ & $\begin{array}{c}\text { Avg. } \\
\text { Infiltration } \\
\text { Rate per } \\
\text { Tracer Gas } \\
\text { Test }(\mathbf{A C H} \\
\text { Natural) }\end{array}$ & $\begin{array}{c}\text { Infiltration } \\
\text { Heat Loss } \\
\left(\mathbf{B t u} / \mathbf{h} /{ }^{\circ} \mathbf{F}\right)\end{array}$ & $\begin{array}{c}\text { Heat Loss per } \\
\text { Co-Heat Test } \\
\text { (Without } \\
\text { Infiltration } \\
\text { Loss) }\end{array}$ & $\begin{array}{c}\left.\text { (Btu/h/ } /{ }^{\circ} \mathbf{F}\right) \\
\text { from Design } \\
\text { UA Value } \\
(\mathbf{\%})\end{array}$ \\
\hline $\mathbf{A}$ & 333 & 0.25 & 43 & 290 & -3.2 \\
\hline B & 256 & 0.24 & 41 & 215 & -8.5 \\
\hline C & 208 & 0.14 & 24 & 184 & 0.4 \\
\hline
\end{tabular}

The heat loss factors predicted by the results of the co-heat/tracer gas tests were used to calibrate the BEopt models and to calculate the heating system COPs.

\subsubsection{Heating System COP}

The COP of the heating system was calculated for all three houses using a co-heat method. For House $\mathrm{B}$ and House $\mathrm{C}$, the COP of the heat pumps was also measured using airflow measurements.

\subsubsection{Co-Heat Tests}

Co-heat tests were conducted during two nights to determine each house's actual heat loss (UA) inclusive of infiltration and duct leakage. The hourly monitored data from the co-heat tests is provided in Appendix G. Ventilation systems were not operating during the co-heat tests.

To calculate the system COPs, the UAs derived from the co-heat tests were used to calculate the heat losses during periods when the systems were operating. Because the derived UAs did not include the effects of fresh air ventilation, this was added to the heat loss based on measured ventilation flows and indoor-outdoor temperature differences. COPs were calculated for 1-h periods from 1:00 a.m. to 6:00 a.m. when the impact of solar gains would be smallest. The equation used to calculate simple heat loss during system operation was:

$$
Q=U A *(\text { Tout }- \text { Tin })+V * c p *(\text { Tout }- \text { Tin })
$$


Where:

$\mathrm{Q}=$ Simple heat loss

$\mathrm{UA}=$ Area-weighted U value of the house's envelope, including walls, roof, floor and fenestration, inclusive of infiltration

Tout $=$ Outdoor ambient temperature

Tin $=$ Average indoor temperature (average of all room temperature sensors)

$\mathrm{V}=$ Effective ventilation rate in cubic feet per minute—average for each hour

$c_{p}=$ Specific heat of air approximated as $1.08^{5}$

Note that this equation assumes that there is no heat recovery in the ventilation heat flow through the building assemblies. COPs were then calculated using the following equation:

$$
C O P=(Q-I G) / Q C
$$

Where:

$$
\begin{aligned}
& \mathrm{Q}=\text { Simple heat loss in } \mathrm{kW} \\
& \mathrm{IG}=\text { Internal gains in } \mathrm{kW} \text {, measured } \\
& \mathrm{Qc}=\text { Heat pump compressor energy in } \mathrm{kW} \text {, measured }
\end{aligned}
$$

\subsubsection{Air-Side Measurements}

The COPs in House B and House $\mathrm{C}$ were also calculated based on measurements of the supply and return air temperatures, fan power measurements, and onetime fan curve generated by measuring the air flow at a range of fan speeds. The following equations were used:

$$
\begin{gathered}
q_{\mathrm{c}, \mathrm{tot}}=m_{\mathrm{da}}(h r-h s) \\
C O P=q_{\mathrm{c}, \text { tot }} / q_{\mathrm{elec}}
\end{gathered}
$$

Where:

$$
\begin{aligned}
& \mathrm{q}_{\mathrm{c}, \text { tot }}=\text { Total heating rate }(\text { sensible }+ \text { latent })(\mathrm{kW}) \\
& \mathrm{q}_{\mathrm{elec}}=\text { Electrical power drawn by outdoor unit }(\mathrm{kW}) \\
& \mathrm{m}_{\mathrm{da}}=\text { Dry air mass flow rate }(\mathrm{kg} / \mathrm{s}) \\
& \mathrm{hr}=\text { Enthalpy of return air }(\mathrm{kJ} / \mathrm{kg} \text { dry air }) \\
& \mathrm{hs}=\text { Enthalpy of supply air }(\mathrm{kJ} / \mathrm{kg} \text { dry air })
\end{aligned}
$$

Enthalpy was calculated using an assumed total atmospheric pressure of $98.9 \mathrm{kPa}$ and measurements of the air's temperature and relative humidity. Correlations for enthalpy as a function of air properties are taken from the 2001 ASHRAE Handbook-Fundamentals, SI P6.9, Equation 32.

\footnotetext{
${ }^{5}$ Converts cubic feet per minute into pounds per hour and multiplies times specific heat of air: $1 \mathrm{cfm} * 60$ minutes per hour $=60 \mathrm{CFH} * .075$ pound per cubic foot $($ standard air $)=4.5 * 0.24$ specific heat of air $=1.08$.
} 
Air flow rate was calculated using a curve fit to the measured air flow rates as a function of electrical power draw of the fan. (See curve below.) The curve fit results in a prediction of volume flow rate. To calculate $\mathrm{m}_{\mathrm{da}}$, the density of the air on the supply side was calculated from the measured temperature and relative humidity and assumed total atmospheric pressure of 98.9 $\mathrm{kPa}$. The mass flow rate of the dry air was then calculated:

Where:

$$
\mathrm{m}_{\mathrm{da}}=p \mathrm{v}_{\mathrm{ma}} /(1+\Phi)
$$

$$
\begin{aligned}
& \mathrm{p}=\text { Density of moist air }\left(\mathrm{kg} / \mathrm{m}^{3}\right) \\
& \mathrm{v}_{\mathrm{ma}}=\text { Volume flow rate of moist air }\left(\mathrm{m}^{3} / \mathrm{s}\right) \\
& \omega=\text { Humidity ratio of moist air }(\mathrm{kg} \text { water } / \mathrm{kg} \text { dry air) }
\end{aligned}
$$

The correlations for the density of air were taken from the 2001 ASHRAE HandbookFundamentals, Chapter 6, Equation 11 and Equation 28.

\subsubsection{Results}

The UAs calculated from the co-heat tests and average COPs for each house under normal operation are shown in Table 19. The hourly data is provided in Appendix G. An estimate for the COPs without the adjustment for ventilation is also included to provide a lower bound for the

\begin{tabular}{|c|c|c|c|}
\hline House & $\mathbf{A}$ & B & $\mathbf{C}$ \\
\hline $\begin{array}{l}\text { Equipment Make and Model } \\
\text { Number }\end{array}$ & $\begin{array}{l}\text { NORDYNE } \\
\text { Electric Furnace } \\
\text { (E3EB010H) }\end{array}$ & $\begin{array}{l}\text { Intertherm Heat } \\
\text { Pump } \\
\text { (DT4BD-018KB \& C8 } \\
\text { (B,D)AM01830U-B) }\end{array}$ & $\begin{array}{l}\text { Mitsubishi } \\
\text { (MSZ-FH15NA } \\
\text { \& MUZ- } \\
\text { FH15NA) }\end{array}$ \\
\hline UA (Incl. Infiltration) $\mathrm{Btu} / \mathrm{h} /{ }^{\circ} \mathbf{F}$ & 313 & 245 & 209 \\
\hline $\begin{array}{l}\text { COP (Co-Heat Method) and } \\
\text { Dates of Measurement (With } \\
\text { Ventilation Adjustment) }\end{array}$ & $\begin{array}{l}1.10 \\
\text { Jan. 1-2 }\end{array}$ & $\begin{array}{l}2.50 \\
\text { Jan. 1-2, 5, 7, } 14\end{array}$ & $\begin{array}{l}2.49 \\
\text { Jan. } 8-12,14, \\
16,25\end{array}$ \\
\hline $\begin{array}{l}\text { COP (Co-Heat Method) and } \\
\text { Dates of Measurement } \\
\text { (Without Ventilation } \\
\text { Adjustment) }\end{array}$ & $\begin{array}{l}1.00 \\
\text { Jan. } 1-2\end{array}$ & $\begin{array}{l}2.26 \\
\text { Jan. } 1-2,5,7,14\end{array}$ & $\begin{array}{l}1.63 \\
\text { Jan. } 8-12,14, \\
16,25\end{array}$ \\
\hline $\begin{array}{l}\text { COP (Air-Side Method) and } \\
\text { Dates of Measurements }\end{array}$ & Not measured & $\begin{array}{l}1.37 \\
\text { Jan. 22-29 }\end{array}$ & $\begin{array}{l}1.39 \\
\text { Jan. } 20-26\end{array}$ \\
\hline $\begin{array}{l}\text { Expected COP, Based on } \\
\text { Manufacturer Data }\end{array}$ & $\begin{array}{l}\text { 1, less that lost via } \\
\text { duct leakage } \\
\text { (electric resistance) }\end{array}$ & $\begin{array}{l}3.2 \text {, less that lost via } \\
\text { duct leakage }\end{array}$ & 4.8 \\
\hline
\end{tabular}
$\mathrm{COP}$ in the event that some natural heat recovery was present in the infiltration flow through the building assemblies.

Table 19. Summary of Heating System COPs 
With the ventilation adjustment, the co-heat measured COP for House A was higher than 1.0, which would be the expected value for an electric resistance system with zero duct losses. (Without the ventilation adjustment, it was 1.0.) The co-heat method COP for House B was similar to what would be expected based on the manufacturer's specifications. The air-side measurement was much lower.

Air-side measurements may be less reliable than measurements based on co-heat because of the uncertain uniformity of supply air measurements. It was noted that the heat pump heating coil in House B was nonuniform in temperature (Figure 28), which may have led to nonuniform supply air. Supply air was measured at a single supply register, which may not have been perfectly representative of the average supply air temperature. Other potential uncertainties include possible temperature differences from one room to another, higher convective airflow due to air handling unit operation than existed during the co-heat tests, and variations in ventilation rates from those estimated. Further, the COP calculations in House A and House B included the effects of duct leakage; therefore, the House A COP should be lower than 1. This is an indication of the magnitude of error inherent in this measurement process. Nevertheless, the COPs calculated by the co-heat method are taken to be close to actual performance.

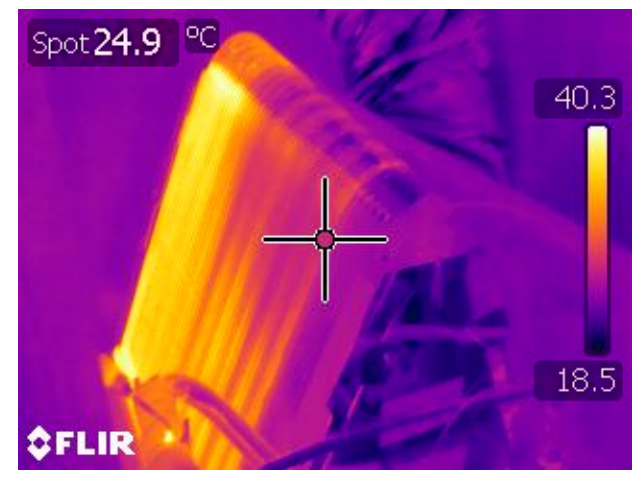

Figure 28. House B refrigerant coil in heating mode showing nonuniform temperatures

The co-heat and air-side COP measurements for House $\mathrm{C}$ are well below the expected COP based on manufacturer data. Discrepancies from these expectations are discussed in more detail below.

\subsubsection{Mini-Split Heat Pump COP}

One possible cause of low COP could be low fan speed and therefore low supply airflow. The fan speed was set to auto-speed mode, in which the air handling unit automatically selects the fan speed based on internal logic. During this period, however, the fan operated at low power (5-7 W) and commensurately low speeds (164-190 cfm) all the time in this mode, even when the heat loads were high.

To further investigate this phenomenon, additional testing was conducted with the fan placed in the high-speed setting. At high speed, the fan drew more power $(9-16 \mathrm{~W})$, and flows increased to 216-306 cfm. Figure 29 shows the air handling unit fan power for the auto- and high-speed settings. Figure 30 shows the fan curve (approximate flows at a range of power levels) established by taking onetime flow and power measurements. 


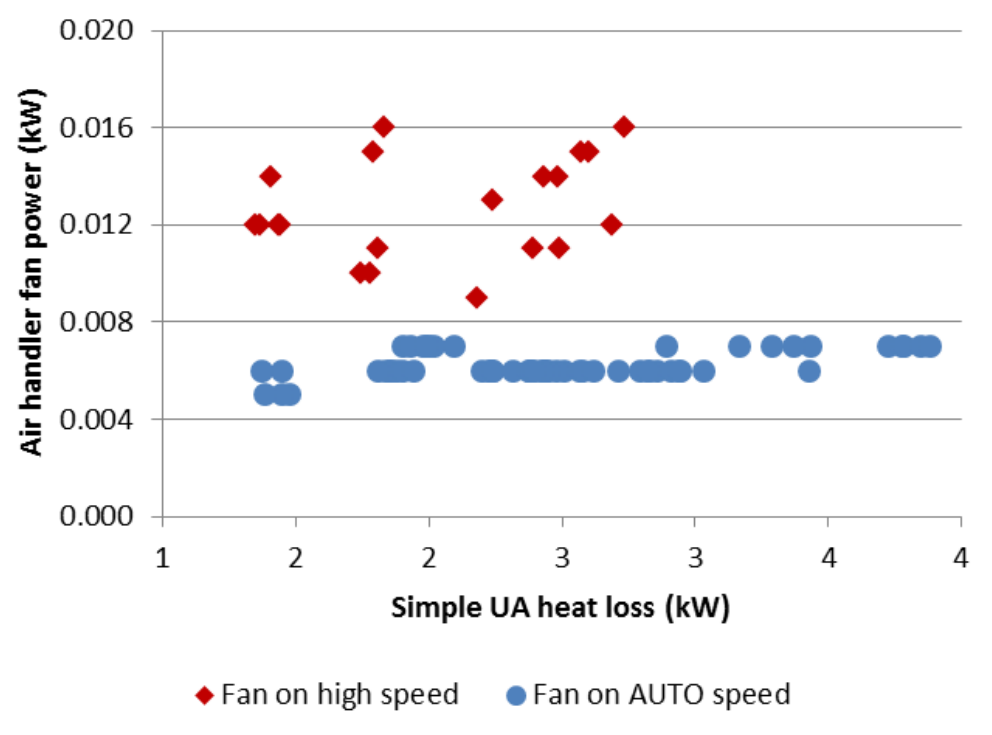

Figure 29. Air handling unit fan power for auto- and high-speed settings

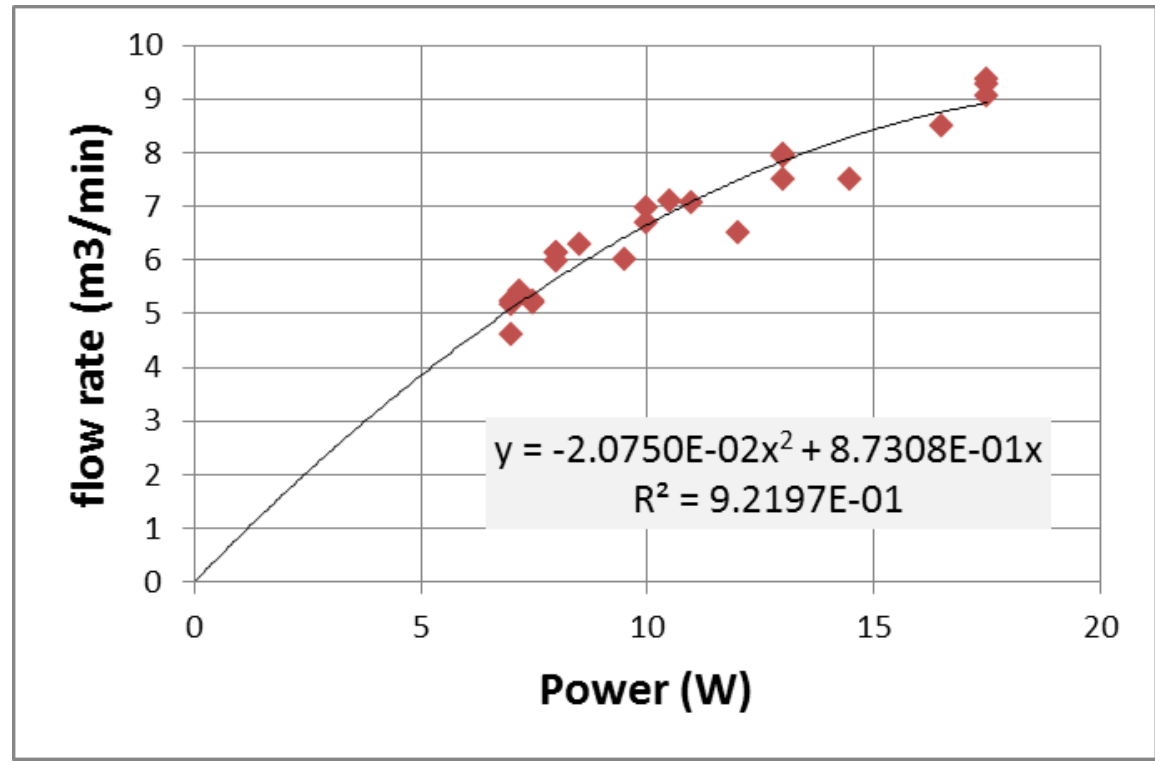

Figure 30. Fan curve based on onetime flow and power measurements

The average COPs calculated from the air-side and co-heat (with ventilation adjustment) methods while the fan was set on high speed (January 27-30) are provided in Table 20 along with a comparison to the auto-speed COPs. 
Table 20. Mini-Split Heat Pump COPs at High and Low Fan Speeds

\begin{tabular}{cccc}
\hline & & High Fan & Auto Fan (Low) \\
\hline \multirow{2}{*}{ Co-Heat Method } & COP & 4.11 & 2.49 \\
& Avg. Ambient Temp. $\left({ }^{\circ} \mathrm{F}\right)$ & 36.8 & 30.7 \\
\multirow{2}{*}{ Air-Side Method } & COP & 2.25 & 1.39 \\
& Avg. Ambient Temp. $\left({ }^{\circ} \mathrm{F}\right)$ & 43.2 & 42.1 \\
\hline
\end{tabular}

Forcing the fan to high speed increased the COP to an average of 4.11 (3.12 without ventilation adjustment) as measured by the co-heat method. The high fan speed COP as measured by the airside method also increased but not as dramatically. It is possible that as airflows increased, the supply air temperature became less uniform across the outlet and the single-point air-side measurement did not capture a truly average reading. Note that average ambient temperature was $6.1^{\circ} \mathrm{F}$ higher during the high-speed period.

Plots of hourly COPs for both measurement methods with outdoor temperature for hours when the fan was on auto compared to high are provided in Figure 31 and Figure 32. The co-heat measurement method has fewer data points because only the hours of 1:00 a.m. to 6:00 a.m. were used.

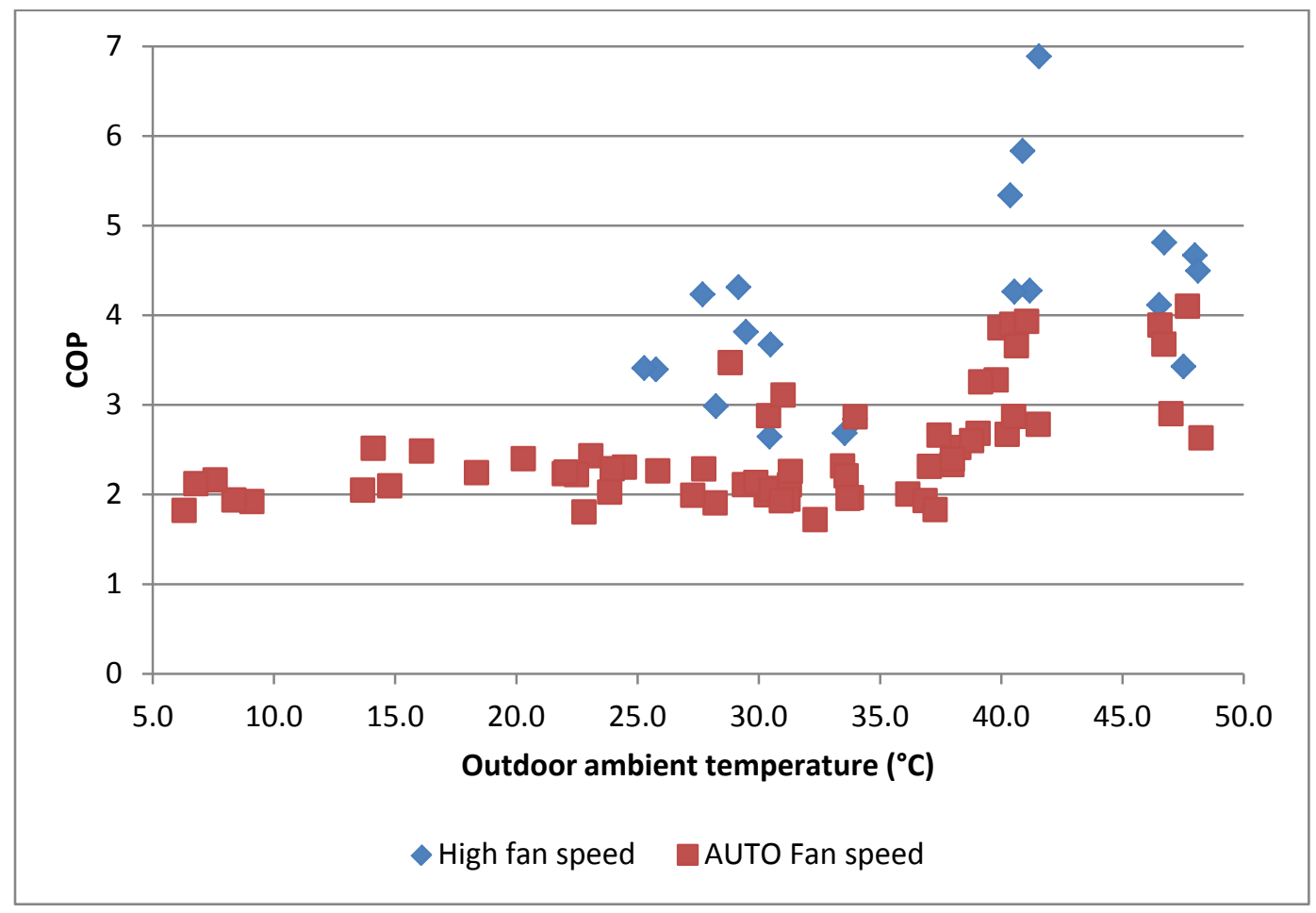

Figure 31. Comparison of mini-split COP (co-heat measurement method) with auto and high fan speeds 


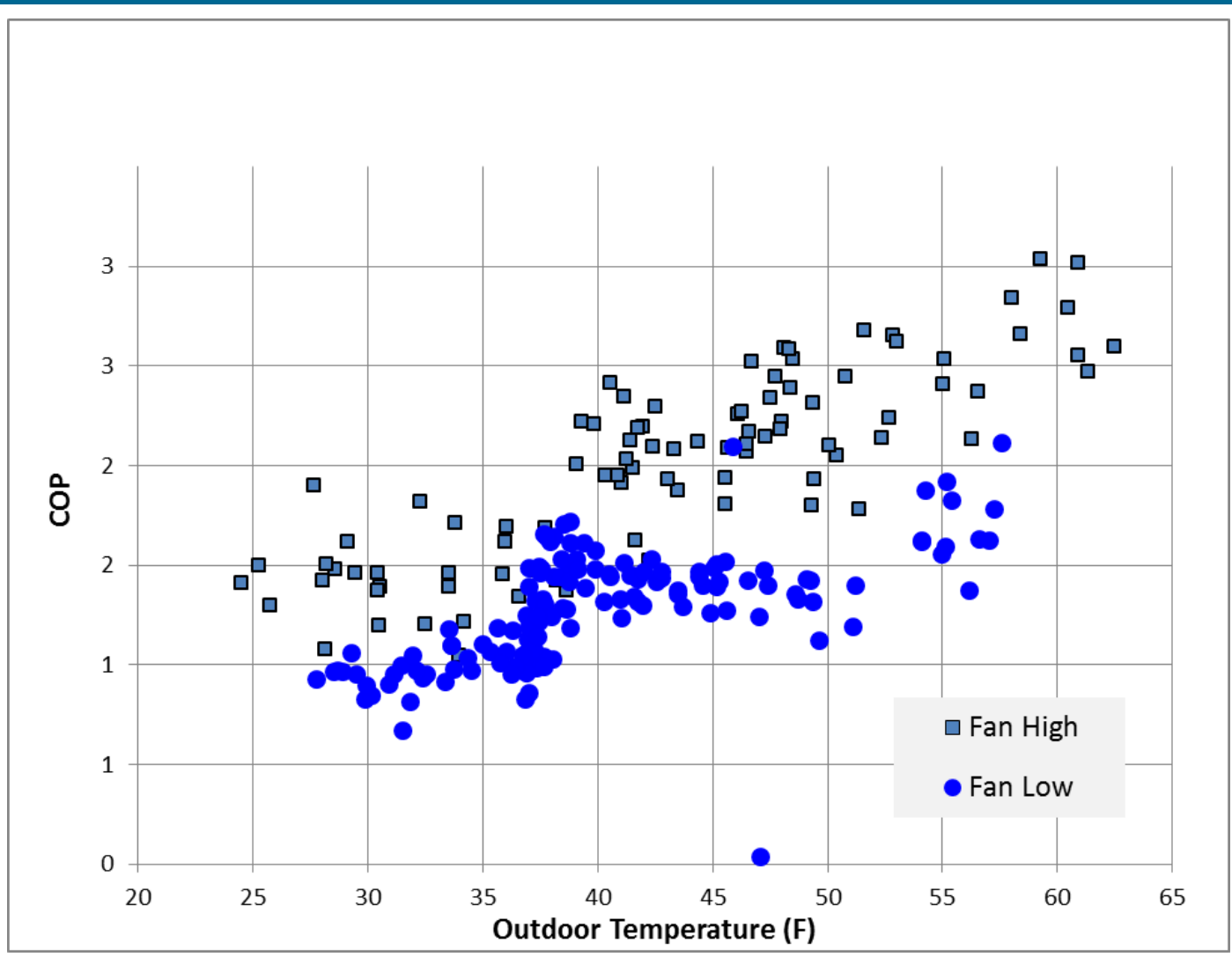

Figure 32. Comparison of mini-split COP (air-side measurement method) with low and high fan speeds

Another possible contributor to low COPs is higher than expected return air temperatures relative to average room temperature. During the period of January 6-13 (the winter sample period), the average temperature in the living space measured in the center of the room at approximately 60 in. above the floor was $70.2^{\circ} \mathrm{F}$; the average return air temperature entering the heat pump was $74.8^{\circ} \mathrm{F}$. There was clearly stratification of indoor air due to thermal buoyancy: the high-low thermocouples in the living room nearest the heat pump measured an average of $68.9^{\circ} \mathrm{F}$ at 12 in. above the floor and $75.4^{\circ} \mathrm{C}$ at 84 in. above the floor during this period.

\subsubsection{Humidification Testing}

One humidifier was placed in each house in the kitchen and set to operate continuously at its normal high output. The humidifiers were weighed at the beginning and end of the test to determine the average moisture injection rate during the test period. The test began at 8:00 a.m. on July 24, 2014, and ended at 6:30 a.m. on July 25. The average injection rates for each house, the average relative humidity, and ambient temperatures before and during the test are provided in Table 21. 
Table 21. Humidification Test Results

\begin{tabular}{cccccc}
\hline & & \multicolumn{2}{c}{ 24 h Before } & \multicolumn{2}{c}{ During } \\
& & \multicolumn{2}{c}{ Humidification Test } & \multicolumn{2}{c}{ Humidification Test } \\
\hline House & $\begin{array}{c}\text { Avg. Moisture } \\
\text { Injection Rate }{ }^{\mathrm{a}}\end{array}$ & $\begin{array}{c}\text { Avg. Relative } \\
\text { Humidity }(\%)\end{array}$ & $\begin{array}{c}\text { Avg. } \\
\text { Ambient } \\
\text { Temp. }\left({ }^{\circ} \mathrm{F}\right)\end{array}$ & $\begin{array}{c}\text { Avg. } \\
\text { Relative } \\
\text { Humidity } \\
(\%)\end{array}$ & $\begin{array}{c}\text { Avg. Ambient } \\
\text { Temp. }\left({ }^{\circ} \mathrm{F}\right)\end{array}$ \\
\hline A & $195 \mathrm{~g} / \mathrm{h}$ & 38.5 & & 39.4 & \\
B & $240 \mathrm{~g} / \mathrm{h}$ & 43.0 & 75.7 & 46.5 & 71.4 \\
$\mathbf{C}$ & $210 \mathrm{~g} / \mathrm{h}$ & 47.8 & & 54.8 & \\
\hline
\end{tabular}

\footnotetext{
${ }^{\mathrm{a}}$ The average moisture injection rate for a three-bedroom home is approximately $200 \mathrm{~g} / \mathrm{h}$ per the Building America protocol.
}

In all three houses, there were only minor increases in measured indoor relative humidity. This indicates that the latent capacity of the cooling systems in each house was adequate to remove this rate of moisture injection. The sensible loads on the cooling systems were high because it was hot outside and the cooling systems were operating frequently to meet that load. The conclusion from this test is that this level of moisture removal $(200 \mathrm{~g} / \mathrm{h})$ is within the capacity of the cooling equipment with the observed sensible heat ratio of approximately 0.75 .

\subsubsection{Impact of Transfer Fans in House C}

The impact of transfer fans on the House $\mathrm{C}$ bedroom and master bathroom room temperatures was analyzed during both the cooling and heating seasons. Periods when all four fans were activated (i.e., being controlled by their dedicated thermostats) were compared to periods when they were all deactivated (Table 22).

Table 22. Analysis Period for the Impact of Transfer Fans on Room Temperatures in House C

\begin{tabular}{ccc}
\hline House & $\begin{array}{c}\text { Transfer Fans } \\
\text { Active Period }\end{array}$ & $\begin{array}{c}\text { Transfer Fans } \\
\text { Deactivated Period }\end{array}$ \\
\hline Cooling Season Dates & July 21-23, 2015 & July 16-8, 2015 \\
\hline Heating Season Dates & Jan. 10-3, 2015 & Jan. 18-21, 2015 \\
\hline
\end{tabular}




\subsection{Cooling Season}

The purpose of the transfer fans during the cooling season was to deliver air from the living room, where the heat pump is located, to the bedrooms and master bathroom. The hypothesis is that the cooler living room air would reduce air temperatures in those rooms and that warmer air would be returned via open doors and transfer grilles back to the living room. Transfer fan flow rates were constant. (See Appendix $\mathrm{C}$ for flow rates.) Fans pulled air from the living room approximately $12 \mathrm{in}$. above the floor and delivered it to the bedrooms/master bathroom at approximately $12 \mathrm{in}$. from the ceiling. A vertical, sealed metal duct was constructed inside the 2 $\mathrm{x} 4$ partition wall to transfer the air.

During this cooling analysis period, the average air temperature near the floor level of the living room (where the transfer fan inlet was) was $73^{\circ} \mathrm{F}$. However, the average temperature at the master bedroom fan outlet was $76.6^{\circ} \mathrm{F}$, indicating that the air might have picked up heat from the fan motor or other source. The average central room temperature in the master bedroom was $76.4^{\circ} \mathrm{F}$, nearly the same as the air being delivered to the room. This is consistent with the comparison of room temperature data from fan-on and fan-off periods - there is no discernable difference in bedroom/master bathroom temperatures at similar outdoor temperatures. The series of graphs in Appendix C plot room temperatures compared to outdoor temperatures for both conditions. The only trend evident is a slight increase in room temperatures with increasing outdoor temperatures. Note that the interior doors were open during these measurements.

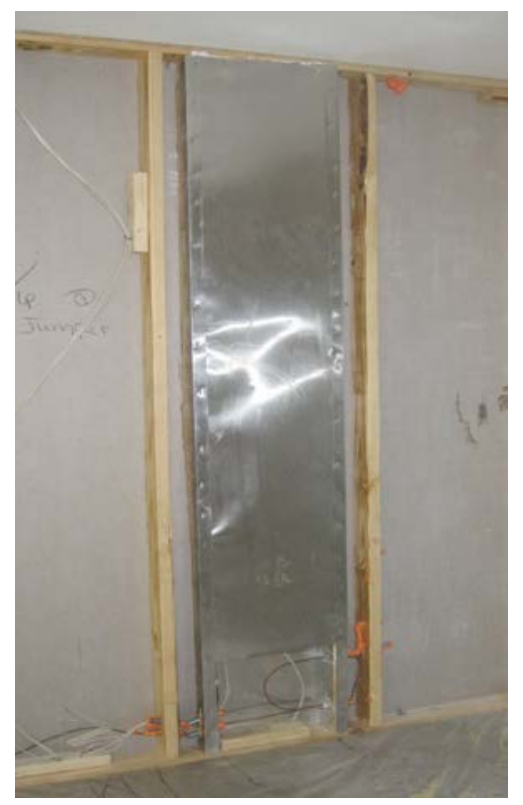

Figure 33. Vertical transfer fan duct

\subsection{Heating Season}

In House C, backup resistance heat was provided to the bedrooms and master bathroom. Therefore, it was not possible to examine the impact of transfer fans on bedroom temperature, which was always at least $69^{\circ} \mathrm{F}$. The purpose of the fans in these conditions would be to reduce the need for resistance heat by bringing warmer living room air into the cooler bedrooms. Because the warmer living room air was heated by the more efficient heat pump, this would be desirable. 
However, it was observed that the resistance heaters were on nearly all of the hours when the transfer fans were on, and they were off nearly all of times when the fans were off. Both were driven by outdoor temperature. Therefore, it was not possible to estimate the impact of transfer fans on the energy consumed by the temperature-controlled heaters during this period, but it would seem that the effect is negligible.

Note that the fans were configured for optimal cooling-season operation-i.e., they pulled air from near the floor level in the living room, which would be the coolest air in the room. The high-low temperature sensors showed consistent temperature stratification in the living room during the heating season, with the floor-level sensors reading $5.2^{\circ} \mathrm{F}$ lower than the ceiling-level sensors and $3.6^{\circ} \mathrm{F}$ lower than the central living room sensor.

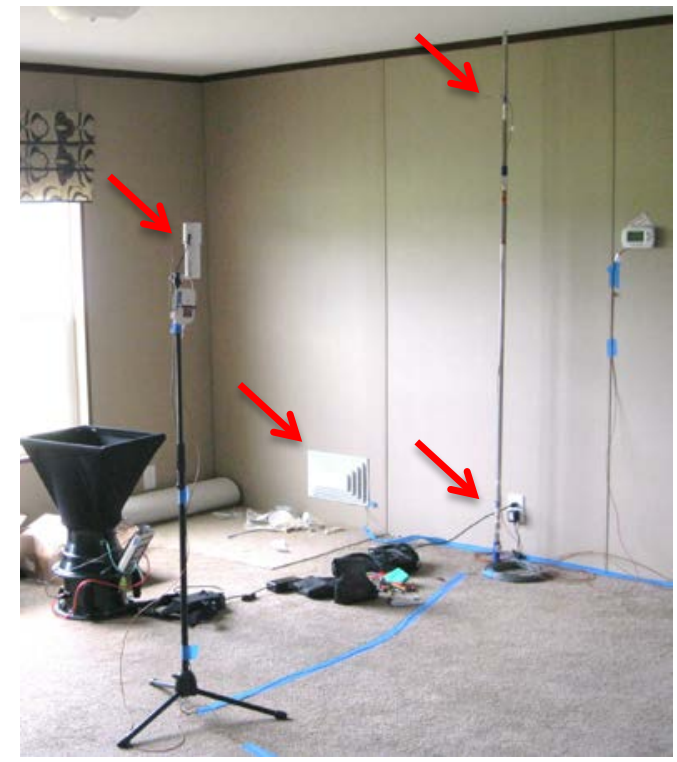

Figure 34. High, low, and primary room temperature sensors

The heat transfer rate from the living room to the master bedroom and master bathroom due to transfer fans was calculated from flow and temperature measurements using the equation below. The results in Table 23 indicate that heat transfer through the fans was low.

Where:

$$
Q f=F * c p *(T l v-T b d)
$$

$\mathrm{Qf}=$ Heat transferred to the bedroom in Btu per hour via the transfer fan

$\mathrm{F}=$ Fan flow rate in cubic feet per minute delivered to the bedroom $/$ master bathroom

Tbd $=$ Bedroom $/$ master bathroom temperature $(\mathrm{F})$

$\mathrm{Tlv}=$ Living room temperature $(\mathrm{F})$

$\mathrm{cp}=$ Specific heat of air approximated as 1.086

\footnotetext{
${ }^{6}$ Converts cubic feet per minute into pounds per hour and multiplies by specific heat of air: $1 \mathrm{cfm} * 60$ minutes per hour $=60 \mathrm{CFH} * .075$ pound per cubic foot (standard air $)=4.5 * 0.24$ specific heat of air $=1.08$
} 
Table 23. Transfer Fan Heat Delivery

\begin{tabular}{ccccc}
\hline Room & $\begin{array}{c}\text { Fan Flow } \\
(\mathbf{c f m})\end{array}$ & $\begin{array}{c}\text { Qf } \\
(\mathbf{B t u} / \mathbf{h})\end{array}$ & $\begin{array}{c}\text { Fan Outlet } \\
\left({ }^{\circ} \mathbf{F}\right)\end{array}$ & $\begin{array}{c}\text { Room } \\
\left({ }^{\circ} \mathbf{F}\right)\end{array}$ \\
\hline Master Bedroom & 106 & 103 & 70.0 & 69.0 \\
\hline Master Bathroom & 115 & 89 & 69.8 & 69.0 \\
\hline
\end{tabular}

\subsubsection{Impact of Window Blinds}

\subsubsection{Cooling Energy}

The impact of window blind position on cooling energy was investigated by comparing the cooling energy consumption of periods when the blinds were completely open to similar periods when the blinds were completely closed. Window treatments were white, horizontal venetian blinds (Figure 35). During the closed periods, the blinds covered $100 \%$ of the windows, and the blind vanes were angled downward toward the outside. The hypothesis was that closed blinds would reduce solar gain and therefore cooling energy. The periods analyzed are described in Table 24.

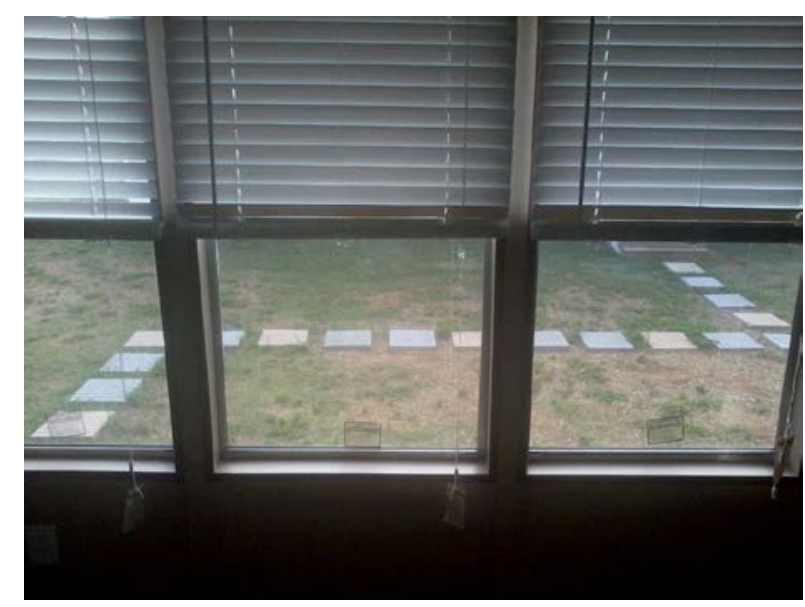

Figure 35 . Window blinds $50 \%$ closed 
Table 24. Window Blinds Analysis Period Conditions

\begin{tabular}{ccc}
\hline House & Blinds Open & Blinds Closed \\
\hline Dates & Aug. 17-23, 2014 & Sept. 23-29, 2014 \\
\hline Avg. Ambient Temp. $\left({ }^{\circ} \mathbf{F}\right)$ & 78.6 & 67.1 \\
\hline Ambient Temp. Range $\left({ }^{\circ} \mathbf{F}\right)$ & $74.5-80.6$ & $62.6-71.8$ \\
\hline $\begin{array}{c}\text { Avg. Indoor Temp. House A } \\
\left({ }^{\circ} \mathbf{F}\right)\end{array}$ & 75.7 & 74.8 \\
\hline $\begin{array}{c}\text { Avg. Indoor Temp. House B } \\
\left({ }^{\circ} \mathbf{F}\right)\end{array}$ & 77.7 & 76.5 \\
\hline $\begin{array}{c}\text { Avg. Indoor Temp. House C } \\
\left({ }^{\circ} \mathbf{F}\right)\end{array}$ & 74.7 & 73.0 \\
\hline $\begin{array}{c}\text { Avg. Direct Normal Solar } \\
\left.\text { Radiation (Btu/ } \mathbf{f t}^{2}\right)\end{array}$ & 1013 & 1102 \\
\hline $\begin{array}{c}\text { Direct Solar Radiation } \\
\left.\text { Range (Btu/ } \mathbf{f t}^{2}\right)\end{array}$ & $341-1,483$ & $274-1,869$ \\
\hline
\end{tabular}

The direct factors affecting the cooling energy consumption during these periods are $\Delta T$ ( $T_{\text {indoor }}{ }^{-}$ $\mathrm{T}_{\text {outdoor }}$ ) and solar radiation received. For "daily" cooling energy and temperature, we used the time periods just before sunrise on Day 1 to just before sunrise on Day 2 (6 a.m. to 6 a.m.), because the solar energy falling on the house during Day 1 would influence the cooling energy past midnight on Day 1, well into the early-morning hours. As shown in Table 24, the average ambient temperature during the period when the blinds were open is nearly $11.5^{\circ} \mathrm{F}$ higher than it was during the period when the blinds were closed. To eliminate the effect of cooler temperatures on cooling energy consumption, the data was normalized (see Appendix $\mathrm{H}$ ). This was done by making a linear fit of the daily cooling energy as a function of $\Delta T\left(T_{\text {indoor }}-T_{\text {outdoor }}\right)$ and the daily totals of direct normal solar radiation during the period when the blinds were closed. This linear fit was used to predict the cooling energy consumption using identical outdoor temperature and direct normal radiation data as that used during the period when the blinds were open.

The sun angles are not very different from August to September, so using a surrogate measure of solar energy such as direct normal radiation is reasonable. A complete cooling-season savings estimate would require modeling sun angles, which was beyond the scope of this analysis; but these data give a strong indication that closing the blinds led to a significant reduction in cooling energy.

The resulting predicted reduction in cooling energy due to closing window blinds in each house is shown in Table 25. Cooling energy reduction was less in House B and House C than it was in House A because those windows have a much lower SHGC than do the windows in House A. 
Table 25. Cooling Energy Reduction Due to Window Blinds

\begin{tabular}{cccc}
\hline & House A & House B & House C \\
\hline Blinds Open Cooling Energy (kWh) & 129.6 & 91.0 & 60.4 \\
Blinds Closed Cooling Energy (kWh) & 81.8 & 72.4 & 44.9 \\
\hline Savings (Blinds Closed vs. Blinds Open) (\%) & 36.9 & 20.4 & 25.7 \\
\hline
\end{tabular}

${ }^{a}$ Predicted using the best-fit equation derived from the regression of delta $\mathrm{T}$ and daily totals of solar radiation as the independent variables and cooling energy as the dependent variable.

\subsubsection{Room Temperature}

The impact of blind position (completely open or completely closed) on room temperatures in the cooling season was also investigated during the same two periods as described above. As expected, closed blinds led to lower room temperatures in House $\mathrm{C}$ in all the rooms (by an average of $2.6^{\circ} \mathrm{F}$ ). In House A and House B, closed blinds did not result in significantly lower room temperatures because the space-conditioning distribution system overcame the effects of the blinds. Appendix C plots room temperature compared to ambient temperature under both blind configurations.

\subsubsection{Impact of Interior Door Position}

The impact of interior door position (open and closed) on room temperatures was investigated during the cooling and heating season. For the majority of the monitoring period, the doors were kept open; however, during selected periods, the doors were closed to compare the effects. These experiments were carried out during the periods shown in Table 26.

Table 26. Interior Door Position Analysis Periods

\begin{tabular}{ccc}
\hline & Doors Open & Doors Closed \\
\hline Cooling Season & June 22-28, 2015 & July 2-8, 2015 \\
Heating Season & Dec. 23-29, 2014 & Dec. 13-19, 2015 \\
\hline
\end{tabular}

\subsubsection{Cooling Season}

Bedroom 2 and Bedroom 3 in House A and House B showed no change to slightly lower temperatures when the doors were closed, indicating that the house had fairly well balanced cooling airflow. The master bedroom in House B showed somewhat elevated temperatures when the door was closed, which is consistent with the lower supply flow per square foot in that room. House A did not show this trend despite the same relatively low supply flow. The master bathrooms in House A and House B both showed lower temperatures when the doors were closed, which is consistent with their high supply flow per square foot and long return-air pathway. In House C, Bedroom 2 and Bedroom 3 showed significant warming when the doors were closed. The master bathroom did not show a difference with closed doors; the room is more distant from the central space, and less air was exchanged with the cooler living room when the doors were open. Likewise, the master bedroom's larger volume and connection to the master bathroom diluted the effect of the open door on room temperature. Plots comparing the bedroom 
temperatures to the ambient temperatures under both door configurations (open and closed) are provided in Appendix C. Table 45 shows the supply flows per square foot of room area.

\subsubsection{Heating Season}

Keeping the doors open resulted in room temperatures closer to the heating set point than they were when the doors were closed. In House A and House B, when the doors were closed at the ambient temperature ranges observed during these periods, the temperature in all rooms except the living room fell below the set point. The outdoor temperature had little effect on the indoor temperatures. This indicates an undersized distribution system for heating in these houses.

In House C, data was collected during periods when the resistance heat in the bedrooms and master bathroom were not active, which enabled an assessment of impact on room temperature. There was a clear trend of decreasing indoor temperatures in House $\mathrm{C}$ as outdoor temperatures decreased. The same trend as in cooling was evident: only Bedroom 2 and Bedroom 3 showed a significant change when the doors were closed (in this case, they became cooler). The master bathroom and small bathroom showed a negligible impact when the doors were closed. Plots comparing the bedroom temperatures to the ambient temperatures under both door configurations (open and closed) for heating are provided in Appendix D.

\subsubsection{Convective Heat Transfer Through Open Doors}

To calculate the convective heat flow through open doors in House C, two test periods were considered while the house was heated by electric resistance heaters and the exhaust fan and heat pump were off: (1) all rooms heated to $69^{\circ} \mathrm{F}$ and (2) bedrooms and master bathroom heated to $69^{\circ} \mathrm{F}$ with the living area heated to $71^{\circ} \mathrm{F}$. The heating energy consumed by the heaters in the master bedroom, master bathroom, Bedroom 2, and Bedroom 3 were compared to each other during these periods (Table 27). The difference in the amount of energy consumed by the bedroom/master bathroom heaters between these two conditions was approximately equal to the heat flow into the bedrooms from the living room. To eliminate the effect of solar radiation, a 3$\mathrm{h}$ nighttime period from $3 \mathrm{a}$ a.m. to 6 a.m. was considered during the course of $4 \mathrm{~d}$ as specified in Table 27, for a total of $12 \mathrm{~h}$.

Table 27. Convective Heat Flow Through Open Doors

\begin{tabular}{|c|c|c|}
\hline Temp. Set Point & $\begin{array}{c}69^{\circ} \mathrm{F} \text { Living Room } \\
69^{\circ} \mathrm{F} \text { Bedrooms/ } \\
\text { Master Bathroom }\end{array}$ & $\begin{array}{c}71^{\circ} \mathrm{F} \text { Living Room } \\
69^{\circ} \mathrm{F} \text { Bedrooms/ } \\
\text { Master Bathroom }\end{array}$ \\
\hline Analysis Period & Feb. 3-6, 2015 & Feb. 14-17, 2015 \\
\hline Avg. Outdoor Temp. $\left({ }^{\circ} \mathbf{F}\right)$ & 24.1 & 24.6 \\
\hline Avg. Crawl Space Temp. $\left({ }^{\circ} \mathbf{F}\right)$ & 39.6 & 33.6 \\
\hline Avg. Attic Temp. $\left({ }^{\circ} \mathbf{F}\right)$ & 23.9 & 27.5 \\
\hline Avg. Wind Speed (m/s) & 0.6 & 0.9 \\
\hline
\end{tabular}

Average ambient temperatures were similar between the two periods; however, there was a difference of $6^{\circ} \mathrm{F}$ in the crawl-space temperature and a difference of $3.6^{\circ} \mathrm{F}$ in the attic temperature between the two periods. The difference in attic temperature could be due to a 
higher thermostat setting in the living room, which caused greater heat loss to the attic than during the period of February 3-6. The higher wind speed might have been the cause of the lower vented-crawl-space temperature of February 14-17.

The difference in the heat loss to the outside from these rooms during the two cases $\left(71^{\circ} \mathrm{F}\right.$ living room and $69^{\circ} \mathrm{F}$ living room) was adjusted based on the known $\mathrm{U}$ values of the building components by using the following equation (results are shown in Table 28):

Where:

$$
Q=U \times A \times \Delta T
$$

$\mathrm{Q}=$ heating energy consumed by the heaters in the rooms in Btu

$\mathrm{U}=\mathrm{U}$ value of the surface area in Btu/h-F

$A=$ area of the surface in square feet

$\Delta \mathrm{T}=$ temperature difference between the rooms and space where heat transfer takes place.

The heat transfer into the bedrooms and master bathroom for all $12 \mathrm{~h}$ considered, when the living room was set to $71^{\circ} \mathrm{F}$ and $69^{\circ} \mathrm{F}$, is shown in Table 29 .

Table 28. Difference in Heat Loss to the Outside Over 12 Hours Between Living Room Set Point at $71^{\circ} \mathrm{F}$ and Living Room Set Point at $69^{\circ} \mathrm{F}$

\begin{tabular}{cccccc}
\hline & $\begin{array}{c}\text { Heat Loss } \\
\text { Through } \\
\text { Attic (Btu) }\end{array}$ & $\begin{array}{c}\text { Heat Loss } \\
\text { Through } \\
\text { Floor (Btu) }\end{array}$ & $\begin{array}{c}\text { Heat Loss } \\
\text { Through } \\
\text { Windows } \\
\text { (Btu) }\end{array}$ & $\begin{array}{c}\text { Heat Loss } \\
\text { Through } \\
\text { Walls (Btu) }\end{array}$ & $\begin{array}{c}\text { Total } \\
\text { Difference }\end{array}$ \\
\hline Bedrooms 2 and 3 & -59 & 554 & 113 & 188 & 796 \\
Master Bedroom & -103 & 972 & 169 & 247 & 1,286 \\
Master Bathroom & -54 & 520 & 56 & 168 & 690 \\
\hline
\end{tabular}

${ }^{a}$ Calculated heat loss to the outside during the two test conditions

Table 29. Heat Transfer into Rooms During $12 \mathrm{~h}$ : Calculations

\begin{tabular}{|c|c|c|c|c|c|}
\hline Row & & BR2 & BR3 & MBR & Mbath \\
\hline 1 & $\begin{array}{l}\text { Heater energy: } 71^{\circ} \text { living room; } \\
69^{\circ} \mathrm{F} \text { bedrooms (Btu) }\end{array}$ & 6,620 & 3,879 & 10,927 & 10,625 \\
\hline 2 & Heater energy: $69^{\circ} \mathrm{F}$ all rooms (Btu) & 12,946 & 8,605 & 19,439 & 11,331 \\
\hline 3 & Difference between rows 1 and 2 (Btu) & 6,326 & 4,725 & 8,512 & 706 \\
\hline 4 & $\begin{array}{l}\text { Adjustment due to difference in heat loss to } \\
\text { outside (from Table 28) (Btu) }\end{array}$ & 796 & 796 & 1,286 & 690 \\
\hline 5 & $\begin{array}{l}\text { Heat transfer into rooms (Row } 3 \text { minus Row 4) } \\
\text { (Btu) }\end{array}$ & 5,548 & 3,948 & 7,259 & 29 \\
\hline
\end{tabular}


Plots of hourly heater energy use in each room as a function of outdoor temperature are provided in Appendix I. Note that there is no direct doorway between the master bathroom and the living room; therefore, heat transfer into this room is low.

Additional calculations were made to separate the conductive heat flow through interior partitions from the convective heat flow through the open door (Table 30). The resulting effective airflow through the doors ranged from 140 to $281 \mathrm{cfm}$. This cfm translates into an air velocity of only about $20 \mathrm{ft} / \mathrm{min}$ (through half the area of an open door). This level of airflow is very difficult to measure and so was not measured directly. Note that there are a number of phenomena that lead to uncertainties with these calculations, including temperature stratification, imperfect mixing of air within rooms, imperfect estimates of component $U$ values, averaging of temperatures, and variations in infiltration to the outside among the two periods. 
Table 30. Convective Heat Transfer Through Open Doors: Calculations

\begin{tabular}{|c|c|c|c|c|c|c|}
\hline Row & & Units & Bedroom 2 & Bedroom 3 & $\begin{array}{c}\text { Master } \\
\text { Bedroom }\end{array}$ & $\begin{array}{c}\text { Master } \\
\text { Bathroom }\end{array}$ \\
\hline 1 & $\begin{array}{l}\text { Avg. } \Delta \mathrm{T} \\
\left(\mathrm{T}_{\text {bedroom }}{ }^{-}\right. \\
\left.\mathrm{T}_{\text {living }}\right)\end{array}$ & $\mathrm{F}$ & 1.8 & 1.8 & 1.8 & 2.0 \\
\hline 2 & $\begin{array}{l}\text { Avg. heat } \\
\text { transfer } \\
\text { into rooms } \\
\text { per hour }\end{array}$ & $\mathrm{Btu} / \mathrm{h}-\mathrm{F}$ & 256 & 182 & 335 & 1 \\
\hline 3 & Wall area & $\mathrm{ft}^{2}$ & 90 & 90 & 92 & 131 \\
\hline 4 & Door area & $\mathrm{ft}^{2}$ & 16.2 & 16.2 & 16.2 & 0 \\
\hline 5 & $\begin{array}{c}\text { U value of } \\
\text { interior } \\
\text { wall }\end{array}$ & $\mathrm{Btu} / \mathrm{h}-\mathrm{ft}^{2}-\mathrm{F}$ & 0.34 & 0.34 & 0.34 & 0.34 \\
\hline 6 & $\begin{array}{l}\text { UA interior } \\
\text { wall }\end{array}$ & Btu/h-F & 30.8 & 30.8 & 31.4 & 44.4 \\
\hline 7 & $\begin{array}{l}\text { UA door } \\
\text { opening } \\
\text { (Row } 2 \text { less } \\
\text { Row 6) }\end{array}$ & Btu/h-F & 225 & 151 & 303 & -44 \\
\hline 8 & $\begin{array}{c}\text { Convective } \\
\text { heat } \\
\text { transfer } \\
\text { through } \\
\text { door }\end{array}$ & $\mathrm{Btu} / \mathrm{h}$ & 405 & 272 & 546 & -87 \\
\hline 9 & $\begin{array}{l}\text { Effective } \\
\text { airflow } \\
\text { through } \\
\text { open door }\end{array}$ & $\mathrm{cfm}$ & 209 & 140 & 281 & N/A \\
\hline
\end{tabular}

\subsection{Data Analysis}

The objective of this analysis was to extrapolate from the measured data the impact on annual energy consumption of the primary measures installed in the lab houses in a range of climates in the Southeast living simulations.

\subsubsection{Climate Locations}

Three locations were selected to represent the range of climates within the service territory of the Tennessee Valley Authority. Table 31 lists the locations along with their respective IECC climate zone, HUD climate zone, manufactured home ENERGY STAR climate region, normal 
heating degree days, and normal cooling degree hours. Maps illustrating the territory and climate zones of the Tennessee Valley Authority are provided in Figure 36.

Table 31. Climate Locations Selected for Modeling

\begin{tabular}{|c|c|c|c|c|c|}
\hline Location & $\begin{array}{c}\text { IECC } \\
\text { Climate } \\
\text { Zone }\end{array}$ & $\begin{array}{c}\text { HUD } \\
\text { Climate } \\
\text { Zone }\end{array}$ & $\begin{array}{c}\text { Manufactured } \\
\text { Home } \\
\text { ENERGY } \\
\text { STAR } \\
\text { Climate } \\
\text { Region }\end{array}$ & $\begin{array}{c}\text { Heating } \\
\text { Degree } \\
\text { Days } \\
\text { (Base 65 }{ }^{\circ} \text { ) }\end{array}$ & $\begin{array}{c}\text { Cooling } \\
\text { Degree } \\
\text { Hours } \\
\left.\text { (Base } 74^{\circ} \mathrm{F}\right)\end{array}$ \\
\hline $\begin{array}{l}\text { Columbus, } \\
\text { Mississippi }\end{array}$ & 3 & 1 & 4 & 2,720 & 26,043 \\
\hline $\begin{array}{l}\text { Knoxville, } \\
\text { Tennessee }\end{array}$ & 4 & 2 & 3 & 3,666 & 14,214 \\
\hline $\begin{array}{c}\text { Bowling Green, } \\
\text { Kentucky }\end{array}$ & 4 & 2 & 2 & 4,314 & 14,745 \\
\hline
\end{tabular}
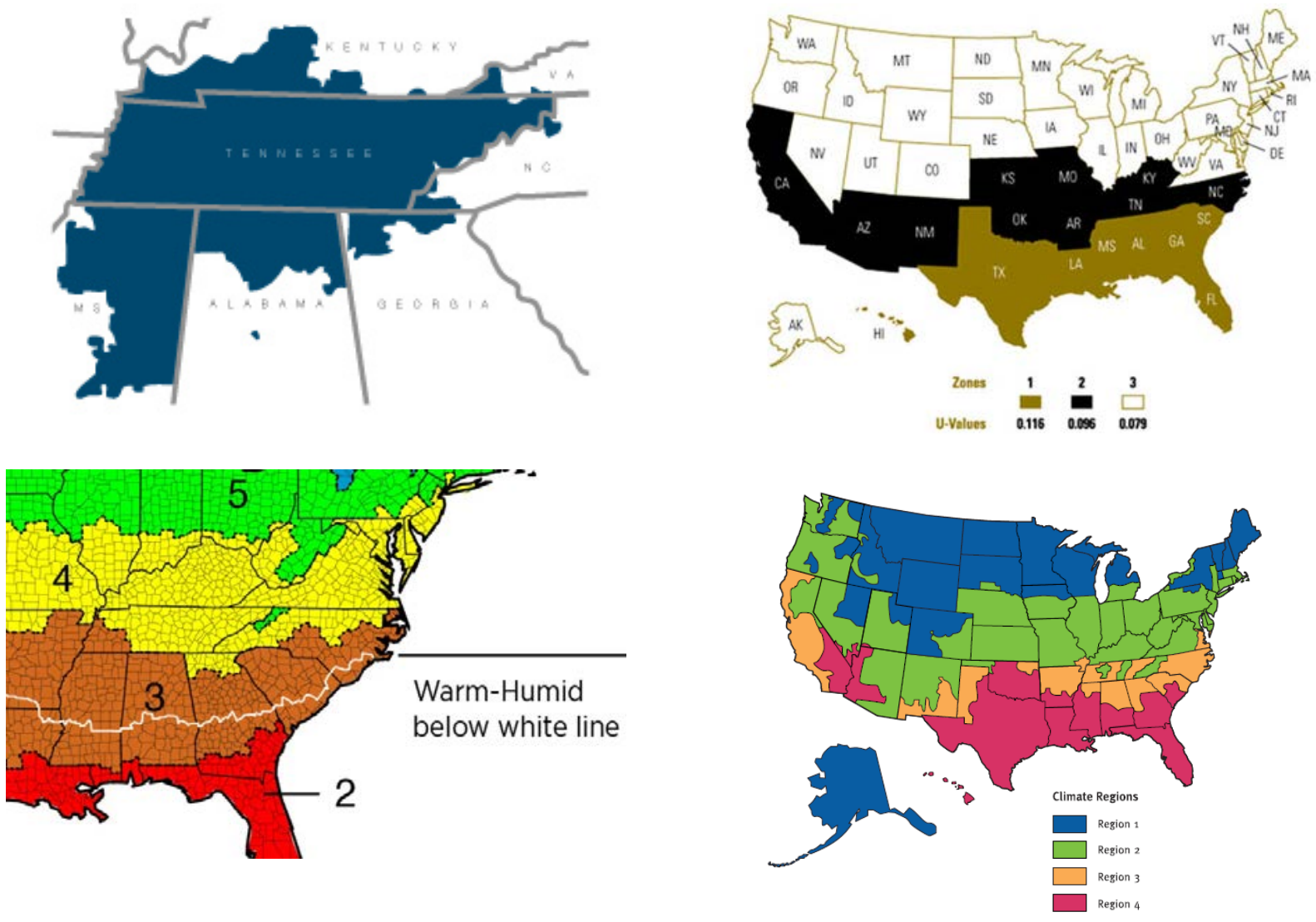

Figure 36. Map of climate locations 


\subsubsection{Model Development and Calibration}

The three houses were modeled using BEopt version 2.3.0.2 with the Energy Plus (version 8-3-0) engine.

Models were calibrated by comparing their output to the measured field data for selected periods of time when the operating conditions were well known (i.e., during periods when resistance heat was used in all three homes). Aspects of the models were then adjusted to better align intermediate outputs (such as attic and crawl space temperatures) to their respective measured conditions and, finally, to compare the modeled to measured space-conditioning energy use of each home.

A measure of calibration accuracy is provided in Table 32. This indicates how accurately the calibrated model predicted overall space-conditioning energy for the selected periods. The periods were chosen when the houses were operating with consistent set points and equipment operation. The resistance heating period was calibrated first because the more precisely known heating energy input for all three houses reduced the number of variables to calibrate. After the resistance heating period was calibrated as closely as possible, the other two periods were calibrated, primarily by tuning the equipment efficiencies.

Table 32. Model Calibration Error ${ }^{\mathrm{a}}$ in Space-Conditioning Energy

\begin{tabular}{cccc}
\hline \multicolumn{3}{c}{ Calibration Period } \\
\hline House & $\begin{array}{c}\text { Resistance Heating Only } \\
\text { (March 7-17) (\%) }\end{array}$ & $\begin{array}{c}\text { As-Built Heating Systems } \\
(\text { Jan. 6-13) (\%) }\end{array}$ & $\begin{array}{c}\text { Cooling } \\
\text { (Aug. 29-Sept. 15) (\%) }\end{array}$ \\
A & -0.56 & -9 & 0 \\
B & -2.3 & 1 & -1 \\
C & 10.85 & $0.64^{\mathrm{a}}$ & 0 \\
\hline
\end{tabular}

${ }^{a}$ The model calibration error equals (modeled - measured)/measured.

${ }^{\mathrm{b}}$ When the energy consumed by the temperature-controlled heaters is predicted by the model.

The model inputs are provided in Table 34, Table 35, and Table 36, along with the basis for the inputs and an explanation of the calibration adjustment to the inputs, if any. 
Table 33. Envelope Inputs for House A, B, and C

\begin{tabular}{|c|c|c|c|c|}
\hline $\begin{array}{l}\text { Type of } \\
\text { Calibration }\end{array}$ & House A & House B & House C & Basis of Adjustment \\
\hline Wall & U: 0.077 & U: 0.077 & U: 0.059 & \multirow{4}{*}{$\begin{array}{l}\text { Modeled UA value for attic ceiling, } \\
\text { floor, walls, windows, and door } \\
\text { adjusted to match the co-heat test } \\
\text { results }\end{array}$} \\
\hline Attic Ceiling & $\mathrm{U}: 0.043$ & $\mathrm{U}: 0.031$ & $\mathrm{U}: 0.022$ & \\
\hline Floor & $\mathrm{U}: 0.074$ & U: 0.043 & U: 0.042 & \\
\hline Window & $\begin{array}{l}\text { U: } 0.47 \\
\text { SHGC: } \\
0.73\end{array}$ & $\begin{array}{l}\text { U: } 0.31 \\
\text { SHGC: } \\
0.33\end{array}$ & $\begin{array}{l}\mathrm{U}: 0.3 \\
\text { SHGC:0.23 }\end{array}$ & \\
\hline Door & $\mathrm{U}: 0.4$ & $\mathrm{U}: 0.4$ & $\mathrm{U}: 0.4$ & $\begin{array}{l}\text { U value for the door was doubled to } \\
\text { account for two doors }\end{array}$ \\
\hline $\begin{array}{l}\text { Interior Shading } \\
\text { (Heating/Cooling } \\
\text { Shade Multiplier) }\end{array}$ & 0.75 & 0.75 & 0.75 & $\begin{array}{l}0.75 \text { indicates a } 25 \% \text { reduction in } \\
\text { solar gain when the blinds cover } \\
50 \% \text { of the effective window area }\end{array}$ \\
\hline $\begin{array}{l}\text { Ratio of Effective } \\
\text { Leakage Area (to } \\
\text { Outside) in } \\
\text { Unfinished Attic to } \\
\text { Total Floor Area }\end{array}$ & $\begin{array}{l}0.0033 \\
\text { (BEopt } \\
\text { default) }\end{array}$ & $\begin{array}{l}0.0033 \\
\text { (BEopt } \\
\text { default) }\end{array}$ & 0.00001 & $\begin{array}{l}\text { Adjusted House } \mathrm{C} \text { to increase attic } \\
\text { temperature to match measured } \\
\text { data }\end{array}$ \\
\hline Air Leakage & $\begin{array}{l}7.7 \\
\mathrm{ACH} 50\end{array}$ & $\begin{array}{l}7.7 \\
\mathrm{ACH} 50\end{array}$ & $5 \mathrm{ACH} 50$ & $\begin{array}{l}\text { Adjusted such that the AIM-II } \\
\text { Model in BEopt would predict air } \\
\text { leakage that matches the measured } \\
\text { air leakage during the tracer gas test } \\
\text { period in Dec. }\end{array}$ \\
\hline
\end{tabular}

Table 34. Model Inputs-House A

\begin{tabular}{|c|c|c|}
\hline Model Input & Value & Basis and Calibration Adjustment (If Any) \\
\hline \multicolumn{3}{|c|}{ Calibration Period: Jan. 6-13 } \\
\hline Electric Furnace & $\begin{array}{l}\text { Capacity: } 34.1 \\
\text { kBtu/h }(10 \mathrm{~kW})\end{array}$ & Capacity: Autosize was modified to $10 \mathrm{~kW}$ \\
\hline $\begin{array}{l}\text { Mechanical } \\
\text { Ventilation }\end{array}$ & 21.56 supply & $\begin{array}{l}\text { Based on flow measurement and air handling unit } \\
\text { run time }\end{array}$ \\
\hline $\begin{array}{l}\text { Duct Leakage } \\
\text { (To outside) }\end{array}$ & $\begin{array}{l}6.5 \mathrm{cfm} 25 / 100 \mathrm{ft}^{2}, \\
\text { all ducts insulated } \\
\text { to } \mathrm{R}-12 \text { located in } \\
\text { pier and beam } \\
\text { (approx. weighted } \\
\text { avg. between R-8 }\end{array}$ & $\begin{array}{l}\text { Original measurement was } 54 \mathrm{cfm} 25 \text { to outside or } \\
4.54 \mathrm{cfm} 25 / 100 \mathrm{ft}^{2} \\
\text { Total duct leakage: } 115 \mathrm{cfm} 25 \\
\text { Original model: } 17 \% \text { ducts insulated to R- } 8 \\
\text { located in pier and beam, } 83 \% \text { ducts located in } \\
\text { conditioned space }\end{array}$ \\
\hline
\end{tabular}




\begin{tabular}{|c|c|c|}
\hline Model Input & Value & Basis and Calibration Adjustment (If Any) \\
\hline & $\begin{array}{l}\mathrm{X} \text {-over duct }+\mathrm{R}-14 \\
\text { in-floor ducts }\end{array}$ & Changed to increase energy use \\
\hline Heating Set Point & $70.1^{\circ} \mathrm{F}$ & $\begin{array}{l}\text { Based on average measured indoor temperature } \\
\text { during this period }\end{array}$ \\
\hline Plug Loads & $153 \mathrm{kWh}$ & $\begin{array}{l}\text { Sum of energy consumed by two sensible gain } \\
\text { heaters and additional not measured internal gain }\end{array}$ \\
\hline \multicolumn{3}{|c|}{ Calibration Period: Aug. 29-Sept. 15} \\
\hline \multicolumn{3}{|l|}{ Central $\mathrm{A} / \mathrm{C}$} \\
\hline $\begin{array}{l}\text { Rated and Installed } \\
\text { SEER }\end{array}$ & 13 & $\begin{array}{l}\text { Rated value; input not used; not considered for } \\
\text { model_EER used for calculations }\end{array}$ \\
\hline $\operatorname{EER}(\mathbf{k B t u} / \mathbf{k W h})$ & 7.1 & $\begin{array}{l}\text { Reduced from } 11 \text { to account for higher measured } \\
\text { cooling use during this period }\end{array}$ \\
\hline $\begin{array}{l}\text { Rated Air Flow Rate } \\
(\mathrm{cfm} / \mathrm{t})\end{array}$ & $705 / 2=353$ & $\begin{array}{l}\text { Rated standard airflow for this model is } 705 \mathrm{cfm} \\
\text { based on specifications from the Air- } \\
\text { Conditioning, Heating, and Refrigeration Institute } \\
\text { Tonnage }=2\end{array}$ \\
\hline $\begin{array}{l}\text { Rated Supply Fan } \\
\text { Power (W/cfm) }\end{array}$ & 0.34 & $400 \mathrm{~W} / 1,160 \mathrm{cfm}$ \\
\hline $\begin{array}{l}\text { Installed Supply Fan } \\
\text { Power (W/cfm) }\end{array}$ & 0.68 & $\begin{array}{l}417 / 980=0.43 \\
\text { Adjustment to increase the fan energy in the } \\
\text { modeled output to match the measured fan energy }\end{array}$ \\
\hline $\begin{array}{l}\text { Mechanical } \\
\text { Ventilation }\end{array}$ & 21.56 cfm supply & $\begin{array}{l}\text { Based on flow measurement and air handling unit } \\
\text { run time }\end{array}$ \\
\hline \multirow[t]{3}{*}{$\begin{array}{l}\text { Duct Leakage } \\
\text { (To outside) }\end{array}$} & $\begin{array}{l}6.5 \mathrm{cfm} / 100 \mathrm{ft}^{2} \\
\text { All ducts insulated }\end{array}$ & $\begin{array}{l}\text { Original measurement was } 54 \mathrm{cfm} \text { to outside or } \\
4.54 \mathrm{cfm} / 100 \mathrm{ft}^{2}\end{array}$ \\
\hline & $\begin{array}{l}\text { to } \mathrm{R}-12 \text { located in } \\
\text { pier and beam }\end{array}$ & $\begin{array}{l}\text { Original model: } 17 \% \text { ducts insulated to R- } 8 \\
\text { located in pier \& beam, } 83 \% \text { ducts located in } \\
\text { conditioned space }\end{array}$ \\
\hline & & Changed to increase energy use \\
\hline Cooling Set Point & $76.28^{\circ} \mathrm{F}$ & $\begin{array}{l}\text { Based on average measured indoor temperature } \\
\text { during this period }\end{array}$ \\
\hline Plug Loads & $277.5 \mathrm{kWh}$ & $\begin{array}{l}\text { Sum of energy consumed by two sensible gain } \\
\text { heaters and additional not measured internal gain }\end{array}$ \\
\hline
\end{tabular}


Table 35. Model Inputs-House B

\begin{tabular}{|c|c|c|}
\hline Model Input & Value & Basis and Calibration Adjustment (If Any) \\
\hline \multicolumn{3}{|c|}{ Calibration Period: Jan. 6-13 } \\
\hline \multicolumn{3}{|l|}{$\begin{array}{l}\text { Air Source Heat } \\
\text { Pump }\end{array}$} \\
\hline $\begin{array}{l}\text { Rated HSPF } \\
\text { (Btu/ W-h) }\end{array}$ & 8 & N/A \\
\hline COP & 3.0 & $\begin{array}{l}\mathrm{COP}=3.2 \text { based on Jon Winkler's } \\
\text { recommendation } \\
\text { Measured COP is } 1.6 . \text { Value adjusted to increase } \\
\text { the heating energy consumption }\end{array}$ \\
\hline $\begin{array}{l}\text { Rated Air Flow Rate } \\
(\mathrm{cfm} / \mathrm{t})\end{array}$ & $\begin{array}{l}1160 / 1.68=690.47 \\
\text { heating }\end{array}$ & $\begin{array}{l}\text { Rated standard airflow for the cooling coil }=580 \\
\text { cfm based on specifications from the Air- } \\
\text { Conditioning, Heating, and Refrigeration Institute } \\
\text { Air handling unit airflow per specification }= \\
1,160 \mathrm{cfm}\end{array}$ \\
\hline $\begin{array}{l}\text { Rated Supply Fan } \\
\text { Power (W/cfm) }\end{array}$ & 0.34 & $400 \mathrm{~W} / 1,160 \mathrm{cfm}$ \\
\hline $\begin{array}{l}\text { Installed Supply Fan } \\
\text { Power (W/cfm) }\end{array}$ & 0.8 & $\begin{array}{l}460 / 1,000=0.46 \\
\text { Adjustment to increase the fan energy in the } \\
\text { modeled output to match the measured fan energy }\end{array}$ \\
\hline $\begin{array}{l}\text { Minimum Temp. } \\
\text { Below Which } \\
\text { Compressor Turns } \\
\text { Off }\end{array}$ & $29^{\circ} \mathrm{F}$ & $\begin{array}{l}\text { Reduced from } 40^{\circ} \mathrm{F} \text { to increase the efficiency of } \\
\text { the heating system to ensure air source heat pump } \\
\text { works for a longer period and matches measured } \\
\text { data }\end{array}$ \\
\hline $\begin{array}{l}\text { Mechanical } \\
\text { Ventilation }\end{array}$ & 12.8 cfm supply & $\begin{array}{l}\text { Based on flow measurement and air handling unit } \\
\text { run time }\end{array}$ \\
\hline $\begin{array}{l}\text { Duct Leakage } \\
\text { (To outside) }\end{array}$ & $\begin{array}{l}0.8 \mathrm{cfm} / 100 \mathrm{ft}^{2} \\
\text { All ducts insulated } \\
\text { to } \mathrm{R}-12 \text { located in } \\
\text { pier and beam }\end{array}$ & $\begin{array}{l}\text { Original measurement was } 9.5 \mathrm{cfm} \text { to outside, or } \\
0.80 \mathrm{cfm} / 100 \mathrm{ft}^{2} \\
\text { Original model: } 17 \% \text { ducts insulated to R- } 8 \\
\text { located in pier and beam, } 83 \% \text { ducts located in } \\
\text { conditioned space }\end{array}$ \\
\hline Heating Set Point & $69.9^{\circ} \mathrm{F}$ & $\begin{array}{l}\text { Based on average measured indoor temperature } \\
\text { during this period }\end{array}$ \\
\hline Plug Loads & $122.6 \mathrm{kWh}$ & $\begin{array}{l}\text { Sum of energy consumed by two sensible gain } \\
\text { heaters and additional not measured internal gain }\end{array}$ \\
\hline \multicolumn{3}{|c|}{ Calibration Period: Aug. 29-Sept. 15} \\
\hline $\begin{array}{l}\text { Air Source Heat } \\
\text { Pump }\end{array}$ & & \\
\hline
\end{tabular}




\begin{tabular}{|c|c|c|}
\hline Model Input & Value & Basis and Calibration Adjustment (If Any) \\
\hline $\begin{array}{l}\text { Rated and Installed } \\
\text { SEER }\end{array}$ & 13 & $\begin{array}{l}\text { Rated value; input not used; not considered for } \\
\text { model_-EER used for calculations }\end{array}$ \\
\hline EER (kBtu/kWh) & 6.5 & $\begin{array}{l}\text { Reduced from } 11 \text { to account for lower efficiency } \\
\text { measured during this period }\end{array}$ \\
\hline \multirow[t]{2}{*}{$\begin{array}{l}\text { Rated Air Flow Rate } \\
(\mathrm{cfm} / \mathrm{t})\end{array}$} & \multirow[t]{2}{*}{$\begin{array}{l}1,160 / 1.5=773 \\
\text { cooling }\end{array}$} & $\begin{array}{l}\text { Rated standard airflow for the cooling coil }=580 \\
\text { cfm based on specifications from the Air- } \\
\text { Conditioning, Heating, and Refrigeration Institute } \\
\text { (did not seem to affect results) }\end{array}$ \\
\hline & & $\begin{array}{l}\text { Air handling unit airflow per specification }= \\
1,160 \mathrm{cfm}\end{array}$ \\
\hline $\begin{array}{l}\text { Rated Supply Fan } \\
\text { Power (W/cfm) }\end{array}$ & 0.34 & $400 \mathrm{~W} / 1,160 \mathrm{cfm}$ (did not affect results) \\
\hline $\begin{array}{l}\text { Installed Supply Fan } \\
\text { Power (W/cfm) }\end{array}$ & 0.80 & $\begin{array}{l}460 / 1,000=0.46 \\
\text { Adjustment to increase the fan energy in the } \\
\text { modeled output to match the measured fan energy }\end{array}$ \\
\hline $\begin{array}{l}\text { Mechanical } \\
\text { Ventilation }\end{array}$ & 12.8 cfm supply & $\begin{array}{l}\text { Based on flow measurement and air handling unit } \\
\text { run time }\end{array}$ \\
\hline \multirow[t]{3}{*}{$\begin{array}{l}\text { Duct Leakage } \\
\text { (To outside) }\end{array}$} & \multirow{3}{*}{$\begin{array}{l}0.8 \mathrm{cfm} 25 / 100 \mathrm{ft}^{2} \\
\text { All ducts insulated } \\
\text { to } \mathrm{R}-12 \text { located in } \\
\text { pier and beam }\end{array}$} & $\begin{array}{l}\text { Original measurement was } 9.5 \mathrm{cfm} 25 \text { to outside, } \\
\text { or } 0.80 \mathrm{cfm} 25 / 100 \mathrm{ft}^{2}\end{array}$ \\
\hline & & Total duct leakage: $36 \mathrm{cfm} 25$ \\
\hline & & $\begin{array}{l}\text { Original model: } 17 \% \text { ducts insulated to R- } 8 \\
\text { located in pier and beam, } 83 \% \text { ducts located in } \\
\text { conditioned space }\end{array}$ \\
\hline Cooling Set Point & $77.36^{\circ} \mathrm{F}$ & $\begin{array}{l}\text { Based on average measured indoor temperature } \\
\text { during this period }\end{array}$ \\
\hline Plug Loads & $277.3 \mathrm{kWh}$ & $\begin{array}{l}\text { Sum of energy consumed by two sensible gain } \\
\text { heaters and additional not measured internal gain }\end{array}$ \\
\hline
\end{tabular}

Table 36. Model Inputs-House C

\begin{tabular}{|c|c|c|}
\hline Model Input & Value & Basis and Calibration Adjustment (If Any) \\
\hline \multicolumn{3}{|c|}{ Calibration Period: Jan. 6-13 } \\
\hline \multicolumn{3}{|c|}{$\begin{array}{l}\text { Mini-Split Heat } \\
\text { Pump }\end{array}$} \\
\hline $\begin{array}{l}\text { Rated HSPF } \\
\text { (Btu/ W-h) }\end{array}$ & 4.2 & $\begin{array}{l}\text { Reduced from } 12 \text { HSPF to account for measured } \\
\text { HVAC energy use and to account for the } \\
\text { temperature controlled heaters in the bedrooms }\end{array}$ \\
\hline
\end{tabular}




\begin{tabular}{|c|c|c|}
\hline Model Input & Value & Basis and Calibration Adjustment (If Any) \\
\hline $\begin{array}{l}\text { Heating Capacity } \\
\text { Offset } \\
(\text { Btu/h) }\end{array}$ & 3,000 & $\begin{array}{l}\text { Nominal heating capacity - nominal heating } \\
\text { capacity }=18,000-15,000\end{array}$ \\
\hline $\begin{array}{l}\text { Minimum Heating } \\
\text { Capacity }\end{array}$ & 0.29 & $\begin{array}{l}\text { Min. capacity/nominal rated capacity }= \\
5,150 / 18,000\end{array}$ \\
\hline $\begin{array}{l}\text { Maximum Heating } \\
\text { Capacity }\end{array}$ & 1.33 & $\begin{array}{l}\text { Max capacity/nominal rated capacity }= \\
24,000 / 18,000\end{array}$ \\
\hline $\begin{array}{l}\text { Min Heating } \\
\text { Airflow }(\mathrm{cfm} / \mathrm{t})\end{array}$ & 134 & Min. heating airflow: $201 \mathrm{cfm}, \mathrm{t}: 1.5$ \\
\hline $\begin{array}{l}\text { Max Heating } \\
\text { Airflow }\end{array}$ & 331.33 & Min heating airflow: $497 \mathrm{cfm}, \mathrm{t}: 1.5$ \\
\hline $\begin{array}{l}\text { Supply Fan Power } \\
\text { (W/cfm) }\end{array}$ & 0.18 & $\begin{array}{l}\text { Full load amps: } 0.67, \mathrm{cfm}: 410 \text { (from the Air- } \\
\text { Conditioning, Heating, and Refrigeration } \\
\text { Institute) }\end{array}$ \\
\hline Minimum Temp. & $-13^{\circ} \mathrm{F}$ & $\begin{array}{l}\text { Specifications indicate } 62 \% \text { heating capacity at } \\
-13^{\circ} \mathrm{F}\end{array}$ \\
\hline Heating Set Point & $70.4^{\circ} \mathrm{F}$ & $\begin{array}{l}\text { Based on average measured indoor temperature } \\
\text { during this period }\end{array}$ \\
\hline Plug Loads & $157.5 \mathrm{kWh}$ & $\begin{array}{l}\text { Sum of energy consumed by two sensible gain } \\
\text { heaters, } 4 \text { transfer fans, and additional not } \\
\text { measured internal gain. Energy consumed by } \\
\text { temperature controlled heaters taken out }\end{array}$ \\
\hline
\end{tabular}

Calibration Period: Aug. 29-Sept. 15

Mechanical $45 \mathrm{cfm}$ exhaust

Ventilation

Mini-Split Heat

Pump

Rated SEER $\quad 15.2$

(Btu/ W-h)

Reduced from 22 SEER to account for measured cooling energy

Minimum Cooling $\quad 0.436$

Capacity

Maximum Cooling $\quad 1.27$

Capacity

Min Cooling Airflow 180 $(\mathrm{cfm} / \mathrm{t})$
Min. capacity/nominal rated capacity $=$ $6,450 / 15,000$

Max. capacity/nominal rated capacity $=$ $19,000 / 15,000$

Min. cooling airflow: $225 \mathrm{cfm}$, t: 1.25 


\begin{tabular}{|c|c|c|}
\hline Model Input & Value & Basis and Calibration Adjustment (If Any) \\
\hline $\begin{array}{l}\text { Max Cooling } \\
\text { Airflow }\end{array}$ & 328.8 & Min. cooling airflow: $411 \mathrm{cfm}, \mathrm{t}: 1.25$ \\
\hline $\begin{array}{l}\text { Supply Fan Power } \\
\text { (W/cfm) }\end{array}$ & 0.18 & $\begin{array}{l}\text { Full load amps: } 0.67, \mathrm{cfm}: 410 \text { (from the Air- } \\
\text { Conditioning, Heating, and Refrigeration } \\
\text { Institute) }\end{array}$ \\
\hline Minimum Temp. & $-13^{\circ} \mathrm{F}$ & $\begin{array}{l}\text { Specifications indicate } 62 \% \text { heating capacity at } \\
-13^{\circ} \mathrm{F}\end{array}$ \\
\hline Heating Set Point & $74.12^{\circ} \mathrm{F}$ & $\begin{array}{l}\text { Based on average measured indoor temperature } \\
\text { during this period }\end{array}$ \\
\hline Plug Loads & $301.114 \mathrm{kWh}$ & $\begin{array}{l}\text { Sum of energy consumed by two sensible gain } \\
\text { heaters, } 4 \text { transfer fans, and additional not } \\
\text { measured internal gain }\end{array}$ \\
\hline
\end{tabular}

\subsubsection{Model Runs}

The calibrated models were then run for each of the three locations. Five models were prepared. Three of the models were created from directly measured data as described above. Two of the models were not built as test homes, so they were simulated by changing only the heating system type (electric resistance to heat pump or vice versa). Because the heating system efficiencies were well known from the measured data, this was done with a high degree of confidence. Note that the modeled home envelopes were not altered for code and program compliance in the different climate locations; rather, they were retained as built. A summary of the five models is provided in Table 37.

Table 37. Summary of Models

\begin{tabular}{|c|c|c|c|}
\hline Model & Thermal Envelope & Space Conditioning & Data Source \\
\hline A1 & HUD code & $\begin{array}{l}\text { Electric resistance furnace; split system } \\
\qquad \mathrm{AC}^{\mathrm{a}}\end{array}$ & Measured \\
\hline A2 & HUD code & Heat pump furnace; split system AC & Simulated \\
\hline B1 & $\begin{array}{l}\text { Manufactured home } \\
\text { ENERGY STAR }\end{array}$ & Electric resistance furnace; split system AC & Simulated \\
\hline B2 & $\begin{array}{l}\text { Manufactured home } \\
\text { ENERGY STAR }\end{array}$ & Heat pump furnace; split system AC & Measured \\
\hline $\mathbf{C}$ & ZERH (IECC 2012) & Ductless mini-split heat pump & Measured \\
\hline
\end{tabular}

${ }^{\mathrm{a}}$ Air conditioner

The calibrated models had sensible gain heaters installed to account for the internal gains due to people, lights, and appliances. To estimate these internal gains in an occupied and functional home, some assumptions were made, as given in Table 38. 
House $\mathrm{C}$ had transfer fans installed in the three bedrooms and the master bathroom; these turned on when the temperatures in those rooms fell below $69^{\circ} \mathrm{F}$ in heating or rose above $76^{\circ} \mathrm{F}$ in cooling. When analyzing the behavior of the transfer fans, it was found that they were on nearly $44 \%$ of the hours during the cooling season and $90 \%$ of the hours during the heating season. This energy was translated into BEopt as miscellaneous plug loads to include in the model the energy use and internal gains due to these fans.

Table 38. Assumptions for Model Runs

\begin{tabular}{|c|c|c|c|}
\hline & Model A and A1 & Model B and B1 & Model C \\
\hline \multirow{2}{*}{ Set Point } & Heating: $68^{\circ} \mathrm{F}$ & Heating: $68^{\circ} \mathrm{F}$ & Heating: $68^{\circ} \mathrm{F}$ \\
\hline & Cooling: $78^{\circ} \mathrm{F}$ & Cooling: $78^{\circ} \mathrm{F}$ & Cooling: $78^{\circ} \mathrm{F}$ \\
\hline $\begin{array}{c}\text { Bathroom Exhaust } \\
\text { Rate } \\
\text { (Default per } \\
\text { Building America } \\
\text { House Simulation } \\
\text { Protocols) }\end{array}$ & $\begin{array}{l}32 \mathrm{cfm} \text { avg. } 60 \mathrm{~min} / \mathrm{d} \\
\text { (intermittent) }\end{array}$ & $\begin{array}{l}26 \mathrm{cfm} \text { avg. } 60 \mathrm{~min} / \mathrm{d} \\
\text { (intermittent) }\end{array}$ & $\begin{array}{l}50 \mathrm{cfm} \text { avg. } 60 \mathrm{~min} / \mathrm{d} \\
\text { (intermittent) }\end{array}$ \\
\hline Bath Fan Power & $0.3 \mathrm{~W} / \mathrm{cfm} / \mathrm{fan}$ & $0.3 \mathrm{~W} / \mathrm{cfm} / \mathrm{fan}$ & $0.3 \mathrm{~W} / \mathrm{cfm} / \mathrm{fan}$ \\
\hline $\begin{array}{c}\text { Kitchen Range Hood } \\
\text { Exhaust } \\
\text { (Changes in Code) }\end{array}$ & $80 \mathrm{cfm}$ & $77 \mathrm{cfm}$ & $\begin{array}{c}110 \mathrm{cfm} 60 \mathrm{~min} / \mathrm{d} \\
\text { (intermittent) (per } \\
\text { HSP) }\end{array}$ \\
\hline Water Heater & $\begin{array}{c}\text { Electric benchmark, } \\
50 \text { gal, } 0.90 \mathrm{EF}\end{array}$ & $\begin{array}{l}\text { Electric standard, } 50 \\
\text { gal, } 0.92 \mathrm{EF}\end{array}$ & $\begin{array}{l}\text { Electric premium, } 50 \\
\text { gal, } 0.95 \mathrm{EF}\end{array}$ \\
\hline Lighting & $100 \%$ incandescent & $100 \%$ incandescent & $\begin{array}{c}80 \% \text { compact } \\
\text { fluorescent lighting }\end{array}$ \\
\hline Refrigerator & $\begin{array}{l}\text { Benchmark = } \\
434 \mathrm{kWh} / \mathrm{yr}\end{array}$ & $\begin{array}{c}0.8 \mathrm{X} \text { benchmark }= \\
347 \mathrm{kWh} / \mathrm{yr}\end{array}$ & $\begin{array}{c}0.8 \mathrm{X} \text { benchmark }= \\
347 \mathrm{kWh} / \mathrm{yr}\end{array}$ \\
\hline Cooking Range & $\begin{array}{l}\text { Benchmark (499 } \\
\text { kWh/yr, electric) }\end{array}$ & $\begin{array}{c}0.8 \text { X benchmark (399 } \\
\mathrm{kWh} / \mathrm{yr} \text {, electric) }\end{array}$ & $\begin{array}{c}0.8 \times \text { benchmark (399 } \\
\mathrm{kWh} / \mathrm{yr} \text {, electric) }\end{array}$ \\
\hline Dishwasher & $\begin{array}{l}\text { Benchmark } \\
(318 \mathrm{kWh} / \mathrm{yr})\end{array}$ & $\begin{array}{l}0.8 \mathrm{X} \text { benchmark } \\
(290 \mathrm{kWh} / \mathrm{yr})\end{array}$ & $\begin{array}{l}0.8 \text { X benchmark } \\
(290 \mathrm{kWh} / \mathrm{yr})\end{array}$ \\
\hline Clothes Washer & $\begin{array}{c}\text { Standard } \\
\left(\mathrm{MEF}^{\mathrm{a}}=1.41\right)\end{array}$ & $\begin{array}{l}\text { ENERGY STAR } \\
(\mathrm{MEF}=2.47)\end{array}$ & $\begin{array}{l}\text { ENERGY STAR } \\
(\mathrm{MEF}=2.47)\end{array}$ \\
\hline Clothes Dryer & Electric $(\mathrm{EF}=3.1)$ & Electric $(\mathrm{EF}=3.1)$ & Electric $(\mathrm{EF}=3.1)$ \\
\hline $\begin{array}{l}\text { Additional Plug } \\
\text { Loads }\end{array}$ & None & None & $\begin{array}{c}\text { Transfer fan energy as } \\
\text { described above }\end{array}$ \\
\hline $\begin{array}{l}\text { Appliance Operating } \\
\text { Schedules }\end{array}$ & $\begin{array}{l}\text { Per the Buildi } \\
\text { (National }]\end{array}$ & $\begin{array}{l}\text { g America House Simul } \\
\text { enewable Energy Labor }\end{array}$ & $\begin{array}{l}\text { ation Protocols } \\
\text { atory 2010) }\end{array}$ \\
\hline
\end{tabular}




\subsubsection{Modeling Results}

Figure 37 through Figure 42 show the results of comparing the five models for each of the three climates. The results are presented in terms of annual site energy consumption in MMBtu/Yr and annual space-conditioning energy in MMBtu/yr (also site energy). All three climates showed similar relationships: Model A1 used the most space-conditioning and ventilation energy, followed by Model B1. The conventional heat pump models (A2 and then B2) were next in consumption. Model $\mathrm{C}$ had the least space-conditioning/ventilation consumption-generally less than half that of A1 and $20 \%$ to $35 \%$ less than the next most efficient model, B2. Because the mini-split heat pump in Model $\mathrm{C}$ is much more efficient than the conventional air-conditioning systems, the reduction in annual energy use was highest in the warmest climate (Columbus, Mississippi) and lowest in the coolest climate (Bowling Green, Kentucky).

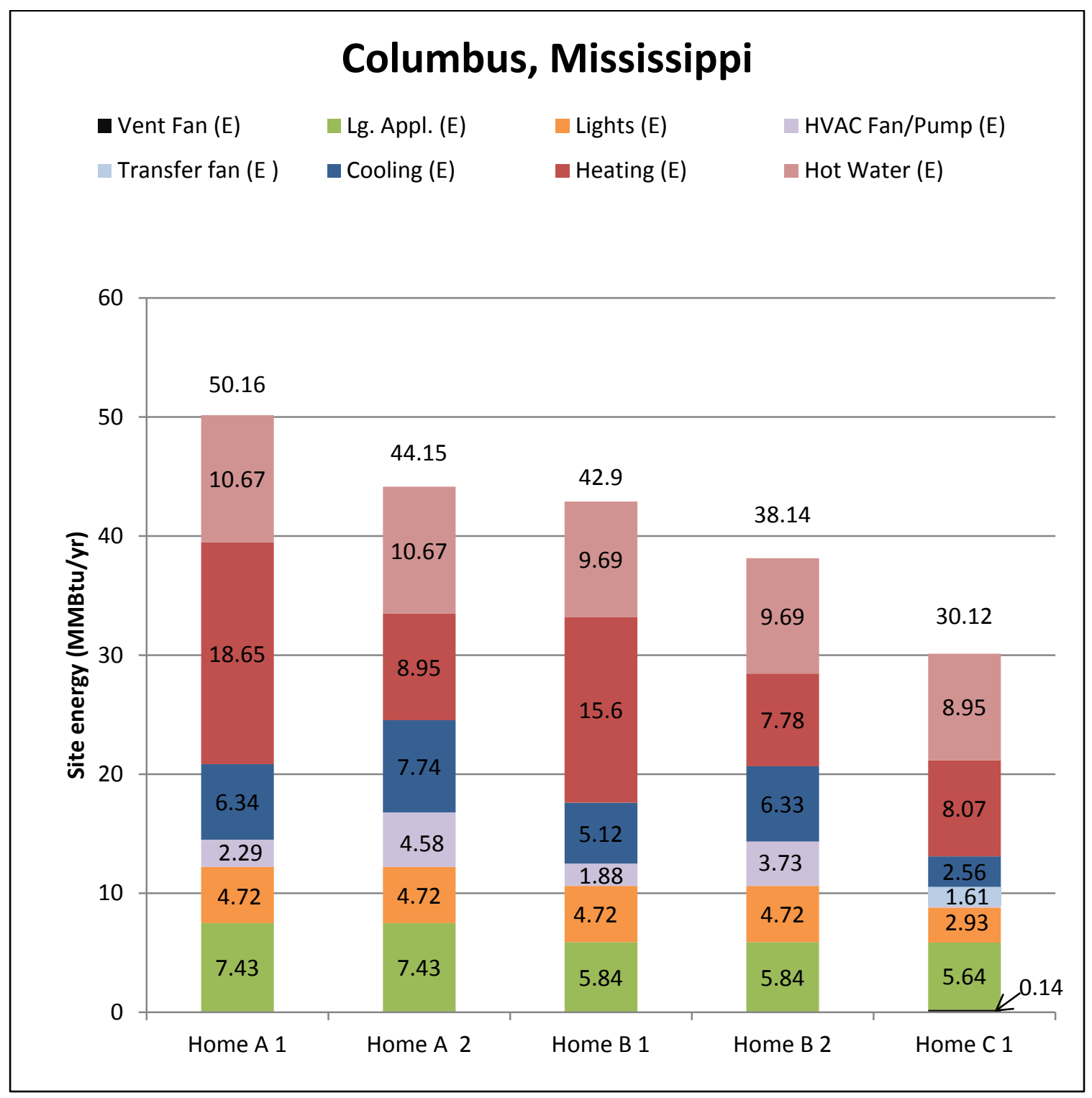

Figure 37. Annual energy consumption comparison-Columbus, Mississippi 


\section{Columbus, Mississippi}

HVAC Fan/Pump (E) $\quad$ Vent Fan (E) $\quad$ Transfer fan (E) $\quad$ Cooling (E) $\quad$ Heating (E)

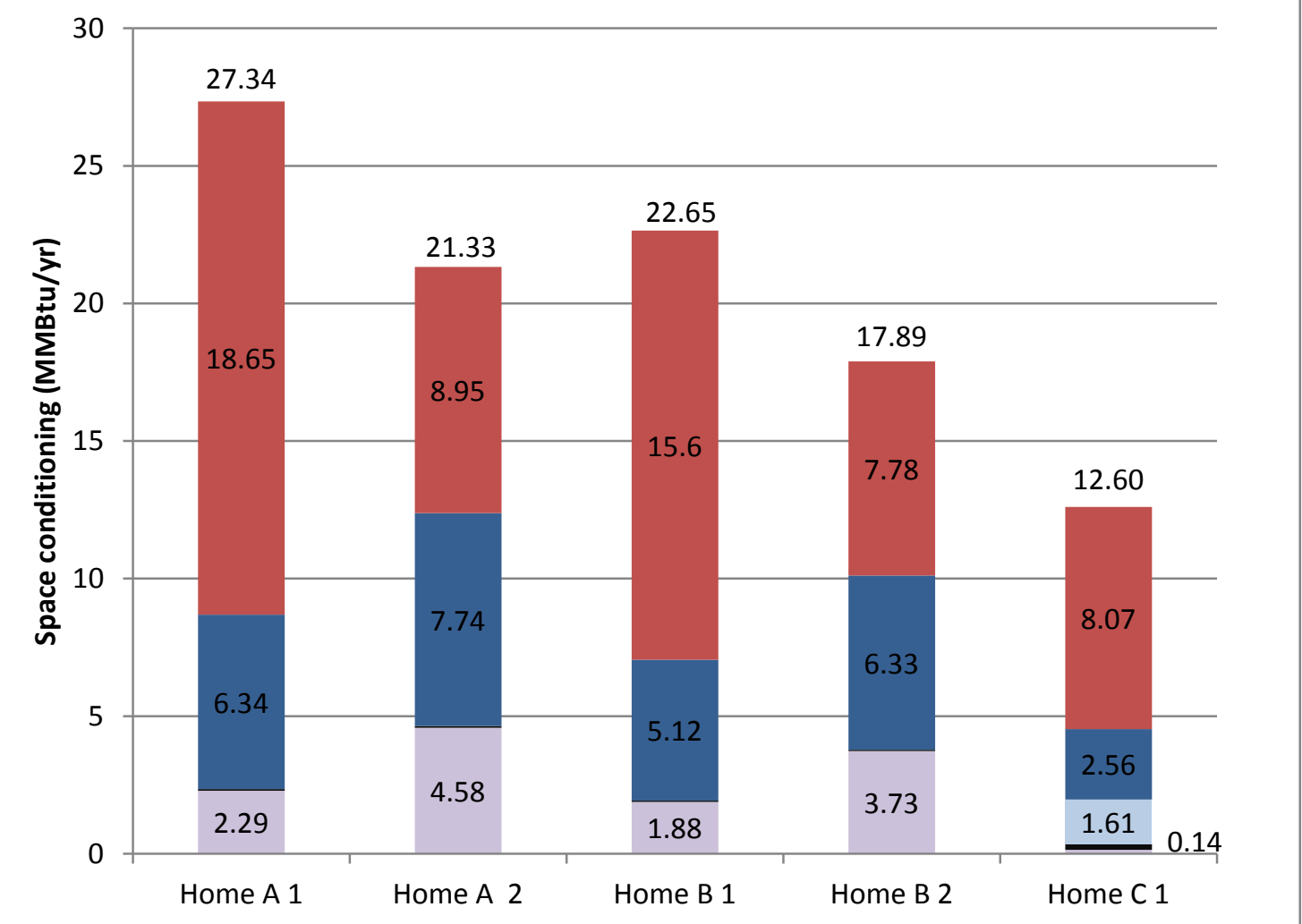

Figure 38. Annual space-conditioning comparison-Columbus, Mississippi 


\section{Knoxville, Tennessee}

\begin{tabular}{|c|c|c|c|}
\hline - Vent Fan (E) & Lg. Appl. (E) & Lights (E) & HVAC Fan/Pump (E) \\
\hline Transfer fan (E) & Cooling (E) & Heating (E) & Hot Water (E) \\
\hline
\end{tabular}

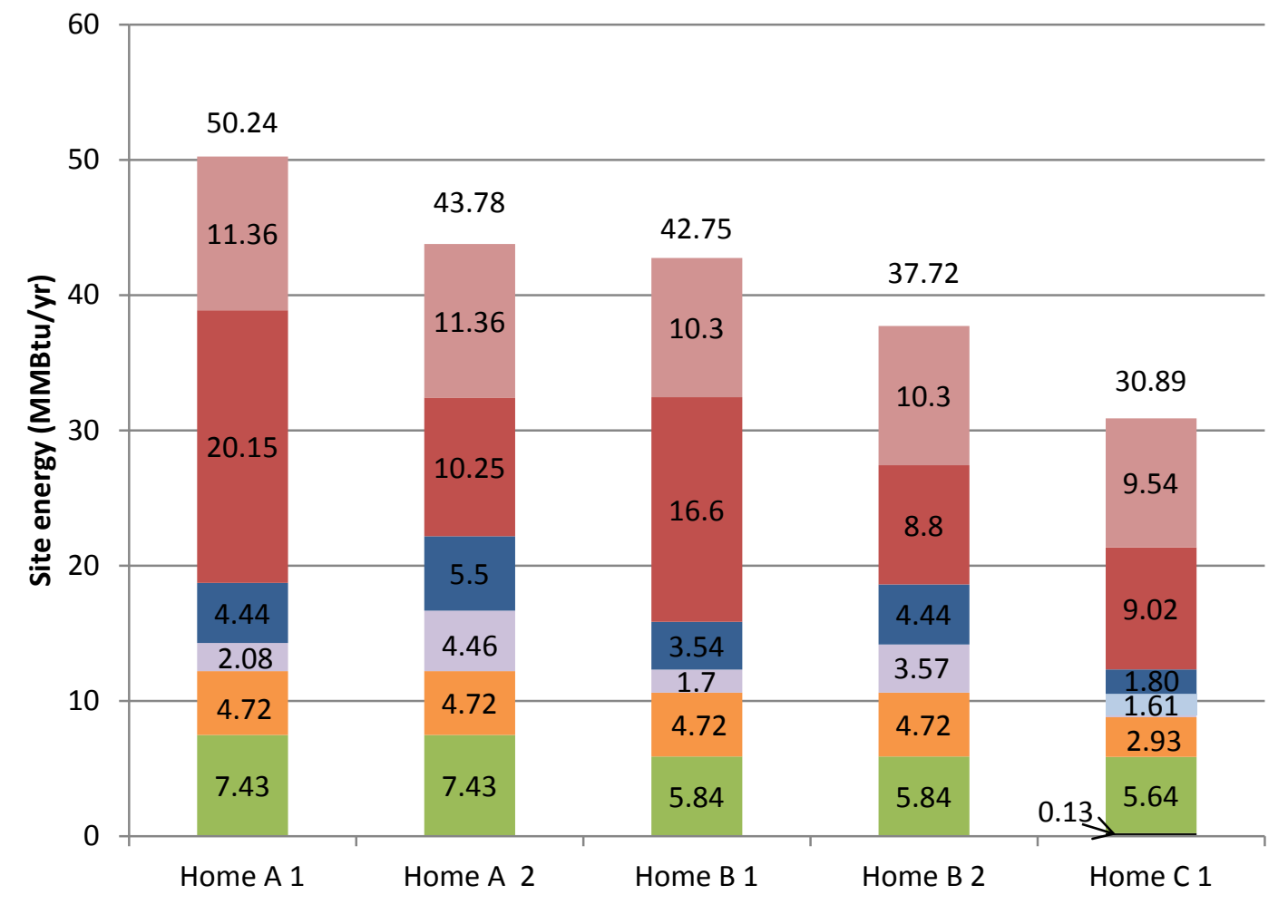

Figure 39. Annual energy consumption comparison-Knoxville, Tennessee 


\section{Knoxville, Tennessee}

$\square$ HVAC Fan/Pump (E) $\quad$ Vent Fan (E) $\quad$ Transfer fan (E) $\quad$ Cooling (E) $\quad$ Heating (E)

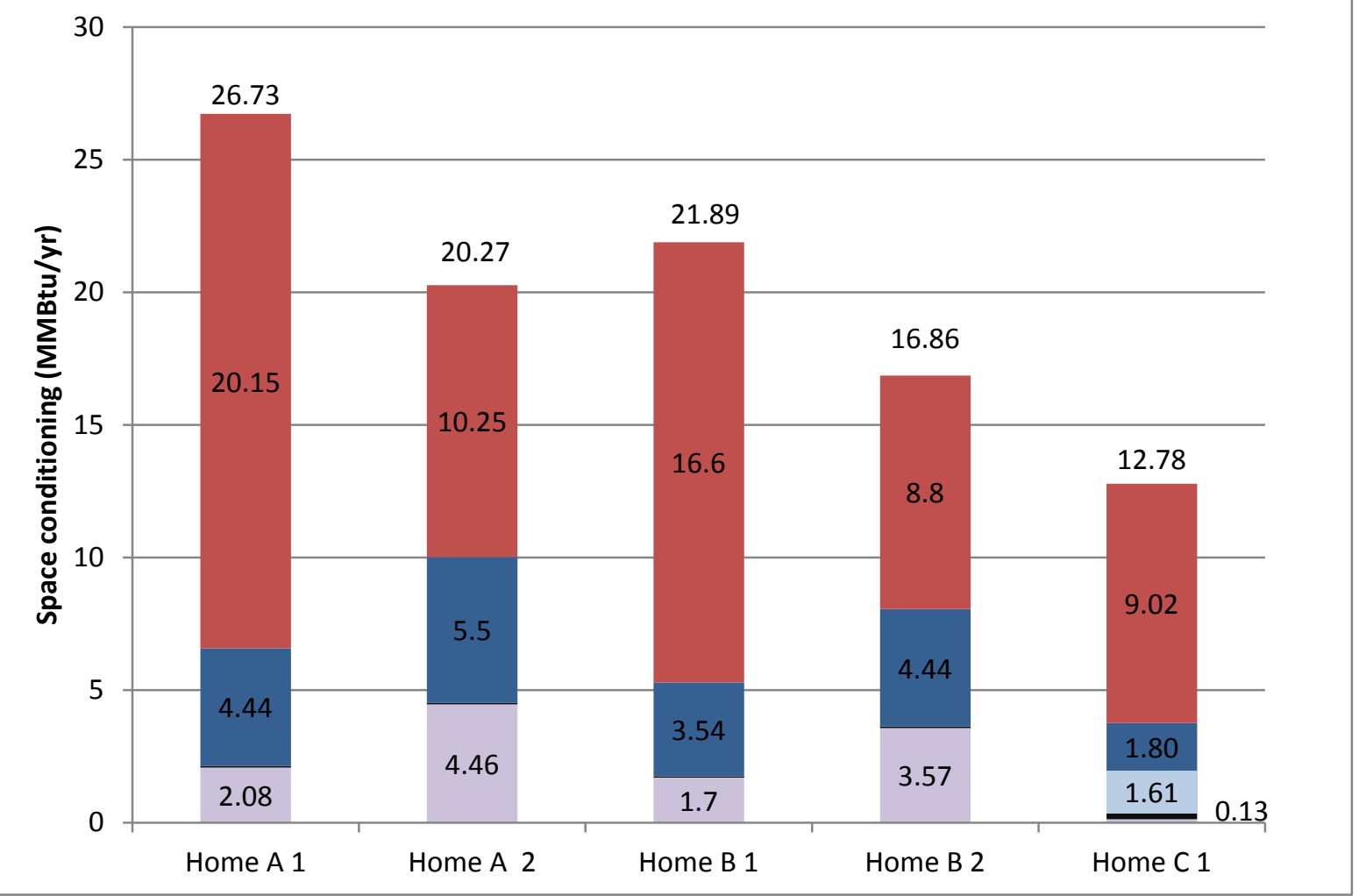

Figure 40. Annual space-conditioning comparison-Knoxville, Tennessee 


\section{Bowling Green, Kentucky}
- Vent Fan (E)
Lg. Appl. (E)
- Lights (E)
HVAC Fan/Pump (E)
- Transfer fan (E)
- Cooling (E)
Heating (E)
Hot Water $(\mathrm{E})$

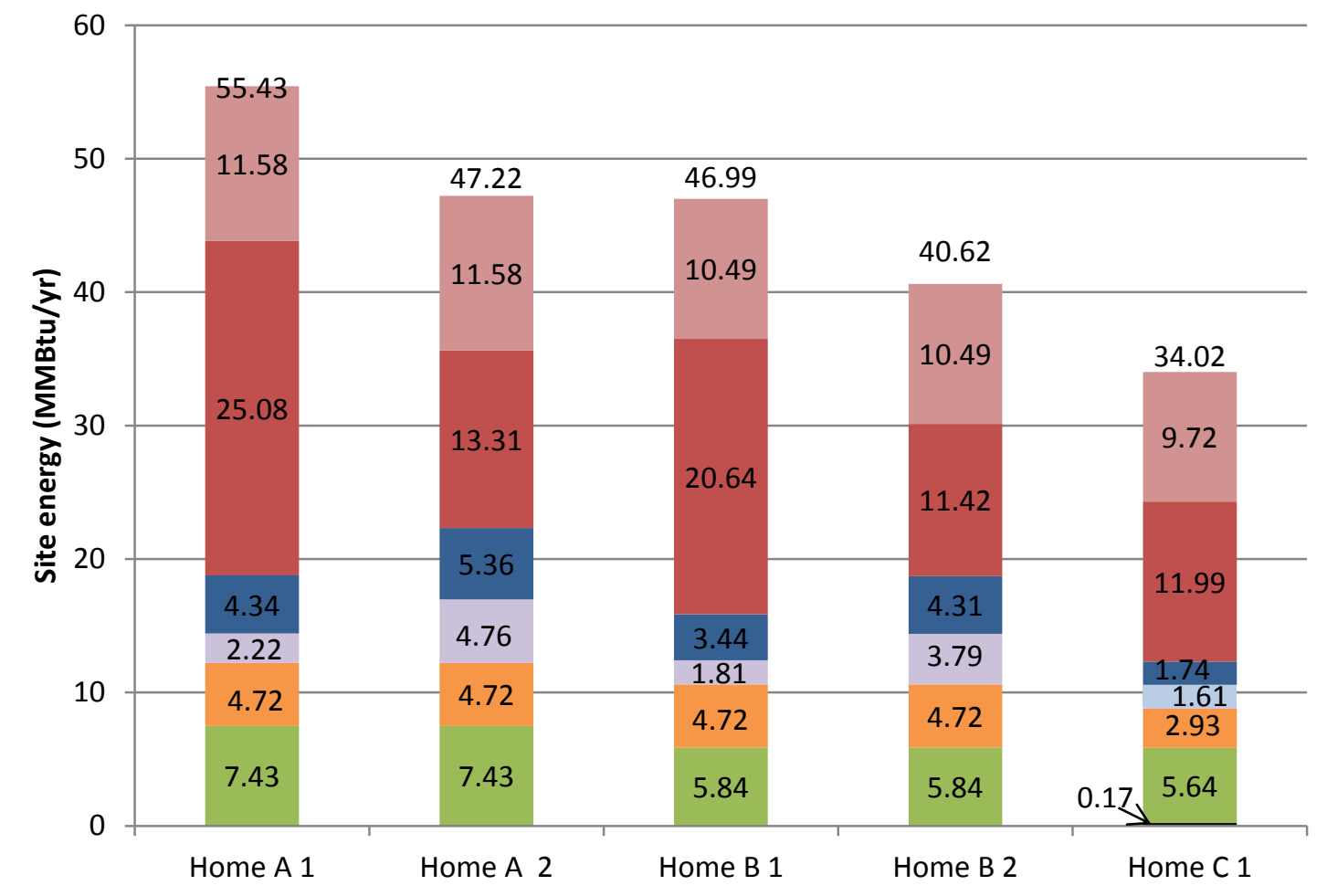

Figure 41. Annual energy consumption comparison-Bowling Green, Kentucky 


\section{Bowling Green, Kentucky}

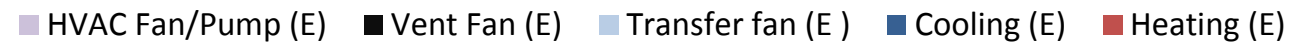

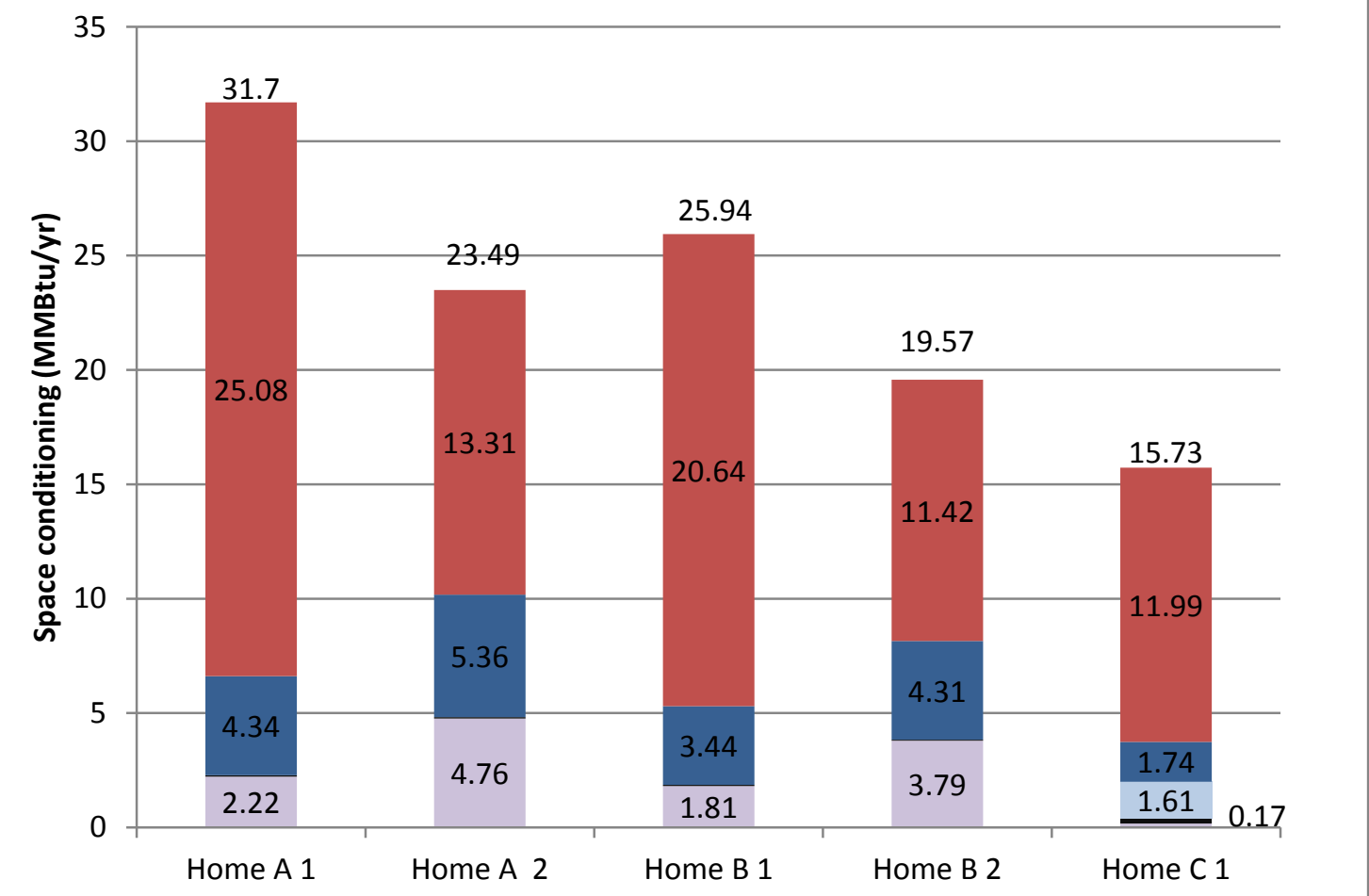

Figure 42. Annual space-conditioning comparison-Bowling Green, Kentucky

\subsubsection{Cost Analysis}

Table 39 shows the itemized costs for each component that differs among the three houses. The total incremental cost to build House C compared to House A was approximately $\$ 2,500$, including non-energy-related measures needed to comply with ZERH criteria. This translates to an approximate $\$ 6,600$ incremental price to the retail homebuyer. 
Table 39. Incremental Costs

\begin{tabular}{|c|c|c|c|c|c|c|c|c|c|}
\hline Item & House A & $\begin{array}{l}\text { \$ } \\
\text { Home- } \\
\text { owner }\end{array}$ & House B & $\begin{array}{l}\text { \$ } \\
\text { Home- } \\
\text { owner }\end{array}$ & House C & $\begin{array}{l}\text { \$ } \\
\text { Home- } \\
\text { owner }\end{array}$ & $\begin{array}{l}\text { Estimated } \\
\text { Incremental } \\
\text { Cost A to B }\end{array}$ & $\begin{array}{l}\text { Estimated } \\
\text { Incremental } \\
\text { Cost B to C }\end{array}$ & $\begin{array}{l}\text { Estimated } \\
\text { Incremental } \\
\text { Cost A to C }\end{array}$ \\
\hline \multirow[t]{2}{*}{$\begin{array}{l}\text { Cooling } \\
\text { Equipment }\end{array}$} & \multirow{2}{*}{$\begin{array}{l}\mathrm{AC} \\
\text { installed, } \\
2 \mathrm{t}\end{array}$} & \multirow[t]{2}{*}{$\$ 2,498$} & \multirow{2}{*}{$\begin{array}{l}\text { HP } \\
\text { installed, } \\
1.5 \mathrm{t}\end{array}$} & \multirow[t]{2}{*}{$\$ 3,015$} & $\begin{array}{l}\text { Mini-split heat } \\
\text { pump }\end{array}$ & $\$ 3,300$ & $\$ 518$ & $\$ 285$ & $\$ 803$ \\
\hline & & & & & $\begin{array}{l}\text { Mini-split heat } \\
\text { pump } \\
\text { installation }\end{array}$ & $\$ 0$ & N/A & $\$ 0$ & $\$ 0$ \\
\hline \multirow[t]{2}{*}{$\begin{array}{l}\text { Heating } \\
\text { Equipment }\end{array}$} & \multirow{2}{*}{$\begin{array}{l}\text { Furnace } \\
\text { installed + } \\
\text { thermo }\end{array}$} & $\$ 333$ & \multirow{2}{*}{$\begin{array}{l}\text { Furnace } \\
\text { installed + } \\
\text { thermo }\end{array}$} & $\$ 333$ & \multirow[t]{2}{*}{$\begin{array}{l}\text { Included in } \\
\text { cooling }\end{array}$} & \multirow[t]{2}{*}{$\$ 0$} & $\$ 0$ & $(\$ 333)$ & $(\$ 333)$ \\
\hline & & $\$ 0$ & & $\$ 0$ & & & $\$ 0$ & $\$ 0$ & $\$ 0$ \\
\hline \multirow[t]{4}{*}{ Distribution } & $\begin{array}{l}\text { Interior } \\
\text { ducts, } \\
\text { material }\end{array}$ & $\$ 232$ & $\begin{array}{l}\text { Interior } \\
\text { ducts, } \\
\text { material }\end{array}$ & $\$ 232$ & $\begin{array}{l}\text { Transfer fans } \\
\text { with fan } \\
\text { center and } \\
\text { duct material }\end{array}$ & $\$ 1,454$ & $\$ 0$ & $\$ 1,222$ & $\$ 1,222$ \\
\hline & $\begin{array}{l}\text { Interior } \\
\text { ducts, } \\
\text { plant labor }\end{array}$ & $\$ 0$ & $\begin{array}{l}\text { Interior } \\
\text { ducts, plant } \\
\text { labor }\end{array}$ & $\$ 0$ & $\begin{array}{l}\text { Transfer fan } \\
\text { thermostat }\end{array}$ & $\$ 176$ & $\$ 0$ & $\$ 176$ & $\$ 176$ \\
\hline & $\begin{array}{l}\text { Crossover } \\
\text { duct, } \\
\text { material }\end{array}$ & $\$ 92$ & $\begin{array}{l}\text { Crossover } \\
\text { duct, } \\
\text { material }\end{array}$ & $\$ 92$ & $\begin{array}{l}\text { Transfer fans, } \\
\text { fan } \\
\text { thermostat, } \\
\text { wiring and } \\
\text { duct } \\
\text { installation }\end{array}$ & $\$ 0$ & $\$ 0$ & $(\$ 92)$ & $(\$ 92)$ \\
\hline & $\begin{array}{l}\text { Crossover } \\
\text { duct, site } \\
\text { labor }\end{array}$ & $\$ 38$ & $\begin{array}{l}\text { Crossover } \\
\text { duct, site } \\
\text { labor }\end{array}$ & $\$ 38$ & N/A & $\$ 0$ & $\$ 0$ & $(\$ 38)$ & $(\$ 38)$ \\
\hline $\begin{array}{l}\text { Insulation- } \\
\text { Ceiling }\end{array}$ & $\begin{array}{l}\mathrm{R}-14 \\
\text { blown } \\
\text { fiberglass }\end{array}$ & $\$ 404$ & $\begin{array}{l}\mathrm{R}-28 \\
\text { blown } \\
\text { fiberglass }\end{array}$ & $\$ 579$ & $\begin{array}{l}\text { R-45 dense- } \\
\text { pack eaves, } \\
\text { blown }\end{array}$ & $\$ 1,089$ & $\$ 175$ & $\$ 510$ & $\$ 685$ \\
\hline
\end{tabular}




\begin{tabular}{|c|c|c|c|c|c|c|c|c|c|}
\hline Item & House A & $\begin{array}{l}\text { \$ } \\
\text { Home- } \\
\text { owner }\end{array}$ & House B & $\begin{array}{l}\text { \$ } \\
\text { Home- } \\
\text { owner }\end{array}$ & House C & $\begin{array}{l}\text { \$ } \\
\text { Home- } \\
\text { owner }\end{array}$ & $\begin{array}{l}\text { Estimated } \\
\text { Incremental } \\
\text { Cost A to B }\end{array}$ & $\begin{array}{l}\text { Estimated } \\
\text { Incremental } \\
\text { Cost B to C }\end{array}$ & $\begin{array}{l}\text { Estimated } \\
\text { Incremental } \\
\text { Cost A to C }\end{array}$ \\
\hline & & & & & fiberglass & & & & \\
\hline $\begin{array}{l}\text { Insulation- } \\
\text { Walls }\end{array}$ & $\begin{array}{l}\mathrm{R}-11 \text { batt } \\
\text { fiberglass }\end{array}$ & & $\begin{array}{l}\mathrm{R}-13 \text { batt } \\
\text { fiberglass }\end{array}$ & $\$ 670$ & $\begin{array}{l}\text { Foam + FG } \\
\text { batt R-13 }\end{array}$ & $\$ 1,606$ & $\$ 670$ & $\$ 936$ & $\$ 1,606$ \\
\hline $\begin{array}{l}\text { Insulation- } \\
\text { Floor }\end{array}$ & $\begin{array}{l}\text { R-14 } \\
\text { blanket } \\
\text { fiberglass }\end{array}$ & $\$ 687$ & $\begin{array}{l}\text { R-28 } \\
\text { blanket } \\
\text { fiberglass }\end{array}$ & $\$ 1,374$ & $\begin{array}{l}\mathrm{R}-28 \text { blanket } \\
\text { fiberglass }\end{array}$ & $\$ 1,374$ & $\$ 687$ & $\$ 0$ & $\$ 687$ \\
\hline \multirow{2}{*}{$\begin{array}{l}\text { Air- } \\
\text { Tightening } \\
\text { Measures }\end{array}$} & N/A & $\$ 0$ & N/A & $\$ 0$ & $\begin{array}{l}\text { Prescriptive } \\
\text { measures }\end{array}$ & $\$ 0$ & $\$ 0$ & $\$ 0$ & $\$ 0$ \\
\hline & & & & & & $\$ 53$ & $\$ 0$ & $\$ 53$ & $\$ 53$ \\
\hline Windows & $\begin{array}{l}\text { Clayton } \\
\text { single plus } \\
\text { storm }\end{array}$ & $\$ 1,382$ & $\begin{array}{l}\text { Clayton } \\
\text { vinyl, low- } \\
\text { emissivity } \\
\text { air filled }\end{array}$ & $\$ 1,600$ & $\begin{array}{l}\text { Clayton vinyl, } \\
\text { low- } \\
\text { emissivity, } \\
\text { argon filled }\end{array}$ & $\$ 2,200$ & $\$ 218$ & $\$ 600$ & $\$ 818$ \\
\hline Doors & Standard & $\$ 769$ & Standard & $\$ 769$ & $\begin{array}{l}\text { One door, low } \\
\text { U-value }\end{array}$ & $\$ 507$ & $\$ 0$ & $(\$ 263)$ & $(\$ 263)$ \\
\hline $\begin{array}{l}\text { Roof } \\
\text { Ventilation }\end{array}$ & N/A & $\$ 0$ & N/A & $\$ 0$ & $\begin{array}{l}\text { AccuVent } \\
\text { baffles }\end{array}$ & $\$ 169.88$ & $\$ 0$ & $\$ 170$ & $\$ 170$ \\
\hline $\begin{array}{l}\text { Interior } \\
\text { Framing }\end{array}$ & $\begin{array}{l}2 \times 3 \\
\text { framing }\end{array}$ & $\$ 0$ & $\begin{array}{l}2 \times 3 \\
\text { framing }\end{array}$ & $\$ 0$ & $\begin{array}{l}\text { Up-charge for } \\
2 \times 4 \text { framing } \\
\text { for transfer } \\
\text { fan walls }\end{array}$ & $\$ 220$ & $\$ 0$ & $\$ 220$ & $\$ 220$ \\
\hline Range Hood & Standard & $\$ 56$ & Standard & $\$ 56$ & $\begin{array}{l}\text { BROAN 30-in } \\
\text { range hood } \\
403001 \text { white }\end{array}$ & $\$ 73.39$ & $\$ 0$ & $\$ 18$ & $\$ 18$ \\
\hline $\begin{array}{l}\text { Water } \\
\text { Heater }\end{array}$ & Standard & $\$ 0$ & Standard & $\$ 0$ & Standard & & $\$ 0$ & $\$ 0$ & $\$ 0$ \\
\hline
\end{tabular}


U.S. DEPARTMENT OF | Energy Efficiency \&

ENERCY Renewable Energy

\begin{tabular}{|c|c|c|c|c|c|c|c|c|c|}
\hline Item & House A & $\begin{array}{l}\text { \$ } \\
\text { Home- } \\
\text { owner }\end{array}$ & House B & $\begin{array}{l}\text { \$ } \\
\text { Home- } \\
\text { owner }\end{array}$ & House C & $\begin{array}{l}\text { \$ } \\
\text { Home- } \\
\text { owner }\end{array}$ & $\begin{array}{l}\text { Estimated } \\
\text { Incremental } \\
\text { Cost A to B }\end{array}$ & $\begin{array}{l}\text { Estimated } \\
\text { Incremental } \\
\text { Cost B to C }\end{array}$ & $\begin{array}{l}\text { Estimated } \\
\text { Incremental } \\
\text { Cost A to C }\end{array}$ \\
\hline $\begin{array}{l}\text { Carbon } \\
\text { Monoxide } \\
\text { Alarms }\end{array}$ & N/A & $\$ 0$ & N/A & $\$ 0$ & $\begin{array}{l}\text { Carbon } \\
\text { monoxide } \\
\text { alarms }\end{array}$ & $\$ 176$ & $\$ 0$ & $\$ 176$ & $\$ 176$ \\
\hline $\begin{array}{l}\text { Ventilation } \\
\text { Fans }\end{array}$ & Ventline & $\$ 46$ & Ventline & $\$ 46$ & Air King x 2 & $\$ 184.80$ & $\$ 0$ & $\$ 138$ & $\$ 138$ \\
\hline Gutters & N/A & $\$ 0$ & N/A & $\$ 0$ & Gutters & $\$ 450$ & $\$ 0$ & $\$ 450$ & $\$ 450$ \\
\hline Refrigerator & Standard & $\$ 775$ & Standard & $\$ 775$ & $\begin{array}{l}\text { ENERGY } \\
\text { STAR model }\end{array}$ & $\$ 774.97$ & $\$ 0$ & $\$ 0$ & $\$ 0$ \\
\hline Dishwasher & Standard & $\$ 378$ & Standard & $\$ 378$ & $\begin{array}{l}\text { ENERGY } \\
\text { STAR model }\end{array}$ & $\$ 378.42$ & $\$ 0$ & $\$ 0$ & $\$ 0$ \\
\hline Lights & N/A & $\$ 0$ & N/A & $\$ 0$ & $\begin{array}{l}\text { Compact } \\
\text { fluorescent } \\
\text { lighting in } \\
80 \%\end{array}$ & $\$ 110$ & $\$ 0$ & $\$ 110$ & $\$ 110$ \\
\hline
\end{tabular}


Because House $\mathrm{C}$ was designed to comply with ZERH criteria, it included some items that were not strictly related to energy efficiency, such as gutters, ventilation fans, and carbon monoxide alarms. Not counting these items, the premiums to build House $\mathrm{C}$ compared to House $\mathrm{A}$ and House B were $\$ 5,843$ and $\$ 3,575$, respectively (price to homebuyer). The modeled energy savings of House C compared to House A and House B ranged from 5.29 to 15.97 MMBtu/yr depending on climate location.

Table 40 through

Table 42 compare the annual utility bill savings in dollars at the average statewide Tennessee electricity rate of $10.59 \notin / \mathrm{kWh}$ (U.S. Energy Information Administration 2015) with the costs for energy measures only.

As shown in the modeling results and in Table 40, the energy savings from House $\mathrm{C}$ compared to House B was the highest in the warmest climate (Columbus), which resulted in a payback period of $14.4 \mathrm{yr}$. House B and House $\mathrm{C}$ showed payback periods that ranged from 4.9 to $9.7 \mathrm{yr}$ across the climates compared to House A. In Bowling Green, House C achieved the largest savings$\$ 664 / \mathrm{yr}$ - compared to House A. House B, the ENERGY STAR home, had the shortest payback period in all climates compared to House A.

Table 40. Energy Savings and Payback-Columbus, Mississippi

\begin{tabular}{cccccccc}
\hline House & $\begin{array}{c}\text { Annual } \\
\text { Utility } \\
\text { Cost }\end{array}$ & $\begin{array}{c}\text { Savings } \\
\text { Compared } \\
\text { to House A }\end{array}$ & $\begin{array}{c}\text { Incr. Retail } \\
\text { Cost } \\
\text { Compared } \\
\text { to House A }\end{array}$ & $\begin{array}{c}\text { Payback } \\
\text { Compared } \\
\text { to House A } \\
(\mathbf{y r})\end{array}$ & $\begin{array}{c}\text { Savings } \\
\text { Compared } \\
\text { to House B }\end{array}$ & $\begin{array}{c}\text { Incr. Retail } \\
\text { Cost } \\
\text { Compared } \\
\text { to House B }\end{array}$ & $\begin{array}{c}\text { Payback } \\
\text { Compared } \\
\text { to House B } \\
(\mathbf{y r})\end{array}$ \\
\hline A & $\$ 1,653$ & N/A & N/A & N/A & N/A & N/A & N/A \\
\hline B & $\$ 1,280$ & $\$ 373$ & $\$ 2,268$ & 6.1 & N/A & N/A & N/A \\
\hline C & $\$ 1,031$ & $\$ 622$ & $\$ 5,843$ & 9.4 & $\$ 249$ & $\$ 3,575$ & 14.4 \\
\hline
\end{tabular}

Table 41. Energy Savings and Payback-Knoxville, Tennessee

\begin{tabular}{cccccccc}
\hline House & $\begin{array}{c}\text { Annual } \\
\text { Utility } \\
\text { Cost }\end{array}$ & $\begin{array}{c}\text { Savings } \\
\text { Compared } \\
\text { to House A }\end{array}$ & $\begin{array}{c}\text { Incr. Retail } \\
\text { Cost } \\
\text { Compared } \\
\text { to House A }\end{array}$ & $\begin{array}{c}\text { Payback } \\
\text { Compared } \\
\text { to House A } \\
(\mathbf{y r})\end{array}$ & $\begin{array}{c}\text { Savings } \\
\text { Compared } \\
\text { to House B }\end{array}$ & $\begin{array}{c}\text { Incr. Retail } \\
\text { Cost } \\
\text { Compared } \\
\text { to House B }\end{array}$ & $\begin{array}{c}\text { Payback } \\
\text { Compared } \\
\text { to House B } \\
\text { (yr) }\end{array}$ \\
\hline A & $\$ 1,656$ & N/A & N/A & N/A & N/A & N/A & N/A \\
\hline B & $\$ 1,263$ & $\$ 393$ & $\$ 2,268$ & 5.8 & N/A & N/A & N/A \\
C & $\$ 1,055$ & $\$ 601$ & $\$ 5,843$ & 9.7 & $\$ 208$ & $\$ 3,575$ & 17.2 \\
\hline
\end{tabular}


Table 42. Energy Savings and Payback-Bowling Green, Kentucky

\begin{tabular}{cccccccc}
\hline House & $\begin{array}{c}\text { Annual } \\
\text { Utility } \\
\text { Cost }\end{array}$ & $\begin{array}{c}\text { Savings } \\
\text { Compared } \\
\text { to House A }\end{array}$ & $\begin{array}{c}\text { Incr. Retail } \\
\text { Cost } \\
\text { Compared to } \\
\text { House A }\end{array}$ & $\begin{array}{c}\text { Payback } \\
\text { Compared } \\
\text { to House A } \\
(\mathbf{y r})\end{array}$ & $\begin{array}{c}\text { Savings } \\
\text { Compared } \\
\text { to House B }\end{array}$ & $\begin{array}{c}\text { Incr. Retail } \\
\text { Cost } \\
\text { Compared to to House B } \\
\text { House B }\end{array}$ & $\begin{array}{c}\text { Payback } \\
\text { Compared } \\
\text { (yr) }\end{array}$ \\
\hline A & $\$ 1,816$ & N/A & N/A & N/A & N/A & N/A & N/A \\
\hline B & $\$ 1,356$ & $\$ 460$ & $\$ 2,268$ & 4.9 & N/A & N/A & N/A \\
\hline C & $\$ 1,152$ & $\$ 664$ & $\$ 5,843$ & 8.8 & $\$ 204$ & $\$ 3,575$ & 17.5 \\
\hline
\end{tabular}




\section{Conclusions}

Following are the research questions and responses:

1. Can factory-built, manufactured homes meet the ZERH requirements as defined? If not, what changes are suggested in the ZERH specifications to better reflect and take advantage of the unique aspects of factory building?

House $\mathrm{C}$ was built in compliance with the HUD code and DOE ZERH criteria. The use of a ductless heat pump simplified the compliance with ENERGY STAR version 3 HVAC requirements. Thermal envelope, ventilation, and indoor air quality requirements were not a barrier, although they did add costs.

2. What are the added costs and energy savings for manufactured ZERHs using ductless mini-split heat pumps compared to the HUD code and ENERGY STAR manufactured homes?

HVAC energy savings in House $\mathrm{C}$ achieved a 50\% reduction compared to the HUD-code home (House A) despite the need for supplemental resistance heat. Room for improvement exists in the form of better air distribution during the heating season, reducing the need for supplemental resistance heating, and improved ductless mini-split COPs, achieved perhaps by increasing airflow rates.. Equipment improvements had a larger impact than envelope improvements. The premium (counting only the energy-efficiency measures) to build House C compared to House A and House B was $\$ 2,060$ and $\$ 1,166$, respectively, at manufacturer cost. The energy savings of House $\mathrm{C}$ compared to House A and House B ranged from 5 to $16 \mathrm{MMBtu} / \mathrm{yr}$ depending on climate location. Paybacks to the homeowner for House $\mathrm{C}$ compared to House A and House B ranged from 8.8 to approximately $17.5 \mathrm{yr}$ based on retail costs.

3. How does point-source space conditioning perform in a ZERH in terms of comfort, and how do operational variables such as opening and closing interior doors and window blinds and the operation of transfer fans affect that performance in heating and cooling modes?

A. Thermal comfort. The point-source heat pump in House $\mathrm{C}$ performed reasonably well in cooling mode. House $\mathrm{C}$ showed the widest temperature fluctuation from one room to another, but only the master bathroom exceeded the upper bounds of the Air Conditioning Contractors of America temperature range (with the interior doors open). In heating mode, the bedrooms did not maintain acceptable temperature in House $\mathrm{C}$; therefore, resistance heaters with dedicated thermostats set to $69^{\circ} \mathrm{F}$ were added to those rooms. This increased energy consumption when the ambient temperature was below freezing.

B. Relative humidity. Relative humidity was within acceptable limits in all houses all year. Latent loads were not simulated; however, short-term humidification testing in summer revealed little impact on indoor relative humidity despite the significant moisture loads being introduced into the buildings, which indicates that the cooling equipment had sufficient excess capacity to handle the latent loads during hot weather. 
C. Transfer fan operation impact on room temperatures. A comparison of fan-on to fan-off periods in House $\mathrm{C}$ did not show a difference in bedroom/master bathroom temperatures at similar outdoor temperatures during both seasons. The interior doors were open during these measurements so the heat transfer through the open doors may have dwarfed that through the fans.

D. Blind position impact on cooling energy. The data showed a strong indication that closing blinds reduced cooling energy needs. Cooling energy was reduced by $20.4 \%$ and $25.7 \%$ in House B and House C, respectively. House A cooling energy was reduced by $36.9 \%$. The higher savings in House $\mathrm{A}$ is theorized to be due to the higher solar heat gain coefficient in the House A windows and a proportionally greater impact on solar gain of the blinds in those circumstances.

E. Blind position impact on room temperatures in cooling. Closing blinds during the cooling season led to lower room temperatures in House $\mathrm{C}$ in all the rooms. In House A and House B, closing the blinds did not result in significantly lower room temperatures, presumably because the space-conditioning distribution system overcame the effects of the blinds on room temperature.

F. Impact of door position on room temperatures. In House $\mathrm{C}$ during the heating season, keeping the doors open resulted in a lower difference in room temperature between the main space and the bedrooms. Bedrooms were $0.4-1.8^{\circ} \mathrm{F}$ lower than the heating set point with the doors open and $4.0-5.4^{\circ} \mathrm{F}$ lower with the doors closed. During cooling season, there was no clear impact on room temperatures of closing interior doors.

G. Convective heat transfer through open doors. Heat transfer through open doors with a two-degree $\mathrm{F}$ temperature difference between the main living space and bedrooms was estimated by measuring the run time of the electric resistance heater and adjusting it based on partition U-values. Effective airflow rates of approximately 140 to $281 \mathrm{cfm}$ were calculated.

\section{What is the in-situ COP in heating of a ductless mini-split heat pump?}

The heating coefficient of performance was calculated for both heat pumps using two independent methods: (1) airflow and temperature measurements and (2) co-heat testing measurements. The co-heat testing method was deemed more reliable. Using this method, the COP of both the conventional split-system heat pump and the ductless mini-split were approximately 2.5. This was well below the expectation for the mini-split based on manufacturer data. However, when the mini-split air handling unit fan was forced to run on its high-speed setting, its COP increased to 4.11, indicating that low airflow could have been a cause of the low heating efficiency of this unit.

\section{Other conclusions}

A. Moisture measurements. Wood moisture content was slightly higher in House C compared to House B, but it was well within safe limits. Higher moisture content was due to the addition of exterior foam insulation to the walls in House $C$ that reduced the vapor permeability of the foam sheathing (extruded polystyrene 
insulation). However, it also resulted in a $5.5^{\circ} \mathrm{F}$ higher minimum condensation surface temperature than in House $\mathrm{B}$, mitigating condensation risk.

B. Peak loads. Peak demand in House $\mathrm{C}$ was significantly lower than it was in the other two houses during all months of the year. House $\mathrm{B}$ had somewhat lower peaks than did House A during most months, but some winter peaks were similar, indicating that House B's peak occurred when the heat pump was not running and the house was relying solely on electric resistance backup. On average, House B had an 18\% lower peak demand than did House A, and House C had a 69\% lower peak demand than did House A during the utility's peak hours. 


\section{References}

National Renewable Energy Laboratory, Building America House Simulation Protocols (Oak Ridge, TN: U.S. Department of Energy's Building America Program, 2010).

Air Conditioning Contractors of America, Manual RS: Comfort, Air Quality, and Efficiency by Design (Arlington, VA: Air Conditioning Contractors of America, 1997).

Aries, M.B.C., and G.R. Newsham, "Effect of Daylight Savings Time on Lighting Energy Use: A Literature Review," Energy Policy 36(6) (2008): 1,858-1,866.

Boudreaux, P.R., A.C. Gehl, and J.E. Christian, "Occupancy Simulation in Three Residential Research Houses," ASHRAE Transactions 118(2) (2011).

Chasar, D., et al., "Cooling Performance Assessment of Building America Homes," Proceedings of the Fifteenth Symposium on Improving Building Systems in Hot Humid Climates FSEC-CR-1673-06 (Cocoa, FL: Florida Solar Energy Center, 2006).

Chasar, D., S. Chandra, V.V VanSchramm, and J. Sherwin, "Measured Performance of Side-bySide South Texas Homes," ASHRAE Transactions (2010).

Chasar, et al., Cold Climate Case Study: High-Efficiency North Dakota Twin Homes (Atlanta, GA: ASHRAE, 2004).

Emery, A.F., and L.M. Gartland, "Quanitfying Occupant Energy Behavior Using Pattern Analysis Techniques," Proceedings of the American Council for an Energy Efficient Economy 1996 Summer Study on Energy Efficiency in Buildings (Washington, D.C, 1996), 8.47-8.59.

Fang, X., D. Christensen, G. Barker, and E. Hancock, Field Test Protocol: Standard Internal Load Generation for Unoccupied Test Homes (Washington, D.C.: U.S. Department of Energy, 2011).

Florida Solar Energy Center, "Optimizing Manufactured Housing Energy Use," Symposium on Improving Building Systems in Hot and Humid Climates (Richardson, TX, 2004).

"Frequently Asked Questions (FAQs)," Forest Products Laboratory, accessed August 27, 2015, http://www.fpl.fs.fed.us/faqs/index.shtml.

Gehl, Anthony C., Jeffery D. Munk, Philip R. Boudreaux, Roderick K. Jackson, and Gannate Khowailed, Tennessee Valley Authority's Campbell Creek Research Homes Project: FY 2012 Annual Performance Report (Oak Ridge, TN: Oak Ridge National Laboratory, 2012).

Grin, A., and J. Smegal, Vancouver Firled Exposure Facility: Phase III Construction and Instrumentation Report (Westford, MA: Building Science Press, 2010).

Hendron, R., et al., Building America Performance Analysis Procedures, Rev. 1.1 (Technical Report) NREL/TP-550-35567 (Golden, CO: National Renewable Energy Laboratory, 2006).

Hendron, Robert, and Cheryn Engebrent, Building America Research Benchmark Definition: Updated December 2009 (Technical Report) NREL/TP-550-47246 (Golden, CO: National Renewable Energy Laboratory, 2009), http://www.eere.energy.gov/buildings/building_america/pdfs/40968.pdf.

Hitchcock, G., "An Integrated Framework for Energy Use and Behaviour in the Domestic Sector," Energy and Buildings 20(2) (1993): 151-157.

Kulakowski, S.L., Large Organizations' Investments in Energy Efficient Building Retrofits (Technical Report) LBNL-40895 (Berkeley, CA: Lawrence Berkeley National Laboratory, 1999). 
Lstiburek, J., "A Crash Course in Roof Venting," Fine Homebuilding August/September (2011).

Lstiburek, J.W., and K. Ueno, Field Testing Unvented Roofs with Asphalt Shingles in Cold and Hot Humid Climates (Washington, D.C.: U.S. Department of Energy, 2015).

Lstiburek, J.W., and A. Rudd. Measurement of Attic Temperatures and Cooling Energy Use in Vented and Sealed Attics in Las Vegas, Nevada (Technical Report) RR-0971 (Westford, MA: Building Science Corporation, 2011).

Lstiburek, J.W., and K. Ueno, Field Testing of Dense Pack Unvented Roofs with Asphalt Shingles (Washington, D.C.: U.S. Department of Energy, 2013).

Lubliner, M., and A. Hadley, "Zero Energy Manufactured Home Project (ZEMH)," Home Energy May/June (2007): 24-29.

Moyer, Neil, David Chasar, Janet McIlvaine, Chuck Withers, and Subrato Chandra, Mositure Problems in Manufactured Housing: Probable Cause and Cure. (Cocoa: Florida Solar Energy Center, 2001).

National Renewable Energy Laboratory, Building America House Simulation Protocols (Oak Ridge, TN: U.S. Department of Energy's Building America Program, 2010.

"Welcome to the PNNL Lab Homes," Pacific Northwest National Laboratory, 2010, http://labhomes.pnnl.gov/.

U.S. Department of Housing and Urban Development, Manufactured Home Construction and Safety Standards (Washington, D.C.: 2010).

U.S. Energy Information Administration, Annual Energy Review (Washington, D.C.: 2010). http://www.eia.doe.gov/totalenergy/data/annual/pdf/sec2.pdf.

Ueno, K., and H. Loomis, Long-Term Monitoring of Mini-Split Ductless Heat Pumps in the Northeast (Technical Report) (Golden, CO: National Renewable Energy Laboratory, 2015).

U.S. Energy Information Administration, Electric Power Monthly June (2015), accessed August 14, 2015, http://www.eia.gov/electricity/monthly/epm_table_grapher.cfm?t=epmt_5_6_a.

Walker, Iain S., and David J. Wilson, "Field Validation of Algebraic Equations for Stack and Wind Driven Air Infiltration Calculations," ASHRAE HVAC\&R Research Journal 4(2) (1998).

Weihl, J.S., and P.M. Gladhart, "Occupant Behavior and Successful Energy Conservation Findings and Implications of Behavior Monitoring," Proceedings of the American Council for an Energy Efficient Economy 1990 Summer Study on Energy Efficiency in Buildings (Washington D.C., 1990): 2.171-2.180.

Yust, B.L., D.A. Guerin, and J.G. Cooper, "Occupant Predictors of Household Energy Behavior and Consumption Change as Found in Energy Studies since 1975," Family and Consumer Sciences Research Journal 29(1) (2000): 48-80.

Yust, B.L., D.A. Guerin, and J.G. Cooper, "Residential Energy Consumption: 1987 to 1997," Family and Consumer Sciences Research Jornal 30(3) (2002): 323-349. 


\section{Appendix A: Commissioning Test Results}

Table 43. Duct Leakage

\begin{tabular}{ccc}
\hline \multicolumn{3}{c}{ Duct Leakage (cfm) } \\
\hline House & Total & To Outside \\
A & $115 \mathrm{cfm}$ & $54 \mathrm{cfm}$ \\
& Fan pressure: $-50.3 \mathrm{~Pa}$ & Fan pressure: $-8.9 \mathrm{~Pa}$ \\
B & Fan pressure: $-31.9 \mathrm{~Pa}$ & Fan Pressure: $-1.2 \mathrm{~Pa}$ \\
C & N/A & N/A \\
\hline
\end{tabular}

Table 44. Total System Flow

\begin{tabular}{ccc}
\hline Pressures Measured at Kitchen Register & House A & House B \\
\hline Normal System Operating Pressure & $46 \mathrm{pa}$ & $42.5 \mathrm{pa}$ \\
Operating Pressure with Duct Blaster Connected & $34 \mathrm{pa}$ & $29 \mathrm{pa}$ \\
Matched System Pressure & $45.5 \mathrm{pa}$ & $42 \mathrm{pa}$ \\
Return Flow at Matching System Pressure & $980 \mathrm{cfm}$ & $1,000 \mathrm{cfm}$ \\
Fan Pressure & & -80.2 \\
\hline
\end{tabular}




\section{Table 45. Supply Register Flows}

\begin{tabular}{|c|c|c|c|c|c|}
\hline Register & $\begin{array}{l}\text { House A (cfm) } \\
\text { (July 23, 2014) }\end{array}$ & House B (cfm) & Room Area $\left(\mathrm{ft}^{2}\right)$ & $\begin{array}{l}\text { House A Supply } \\
\left(\mathrm{cfm} / \mathbf{f t}^{2}\right)\end{array}$ & $\begin{array}{c}\text { House B Supply } \\
\left(\mathrm{cfm} / \mathrm{ft}^{2}\right)\end{array}$ \\
\hline $\begin{array}{l}\text { Northwest } \\
\text { Bedroom }\end{array}$ & 136 & 120 & 142 & 1.0 & 0.8 \\
\hline Bathroom 2 & LO & 76 & 43 & $\mathrm{LO}$ & 1.8 \\
\hline Kitchen & 152 & 130 & 159 & 1.0 & 0.8 \\
\hline Dining Room & 140 & 133 & 132 & 1.1 & 1.0 \\
\hline Master Bathroom & 151 & 156 & 131 & 1.2 & 1.2 \\
\hline $\begin{array}{l}\text { Master } \\
\text { Bedroom }\end{array}$ & 126 & 123 & 234 & 0.5 & 0.5 \\
\hline Living Room & 116 & 118 & \multirow{2}{*}{232} & \multirow{2}{*}{1.0} & \multirow{2}{*}{1.0} \\
\hline Entry & 124 & 104 & & & \\
\hline $\begin{array}{l}\text { Northeast } \\
\text { Bedroom }\end{array}$ & 109 & 93 & 137 & 0.8 & 0.7 \\
\hline TOTAL & 1,054 & 1,053 & 1,210 & 0.87 & 0.87 \\
\hline
\end{tabular}

Table 46. Ventilation Flows

\begin{tabular}{cccccc}
\hline \multirow{2}{*}{ House } & Whole-House Ventilation & \multicolumn{2}{c}{ Exhaust Fan Flow (cfm) } & \multirow{2}{*}{ Range Hood (cfm) } \\
\cline { 3 - 4 } & Flow (cfm) & Master Bathroom & Bathroom 2 & \\
A & 44 & 46 & 18 & 80 \\
B & 32 & 40 & 12 & 77 \\
\hline
\end{tabular}


Table 47. House A Envelope Leakage

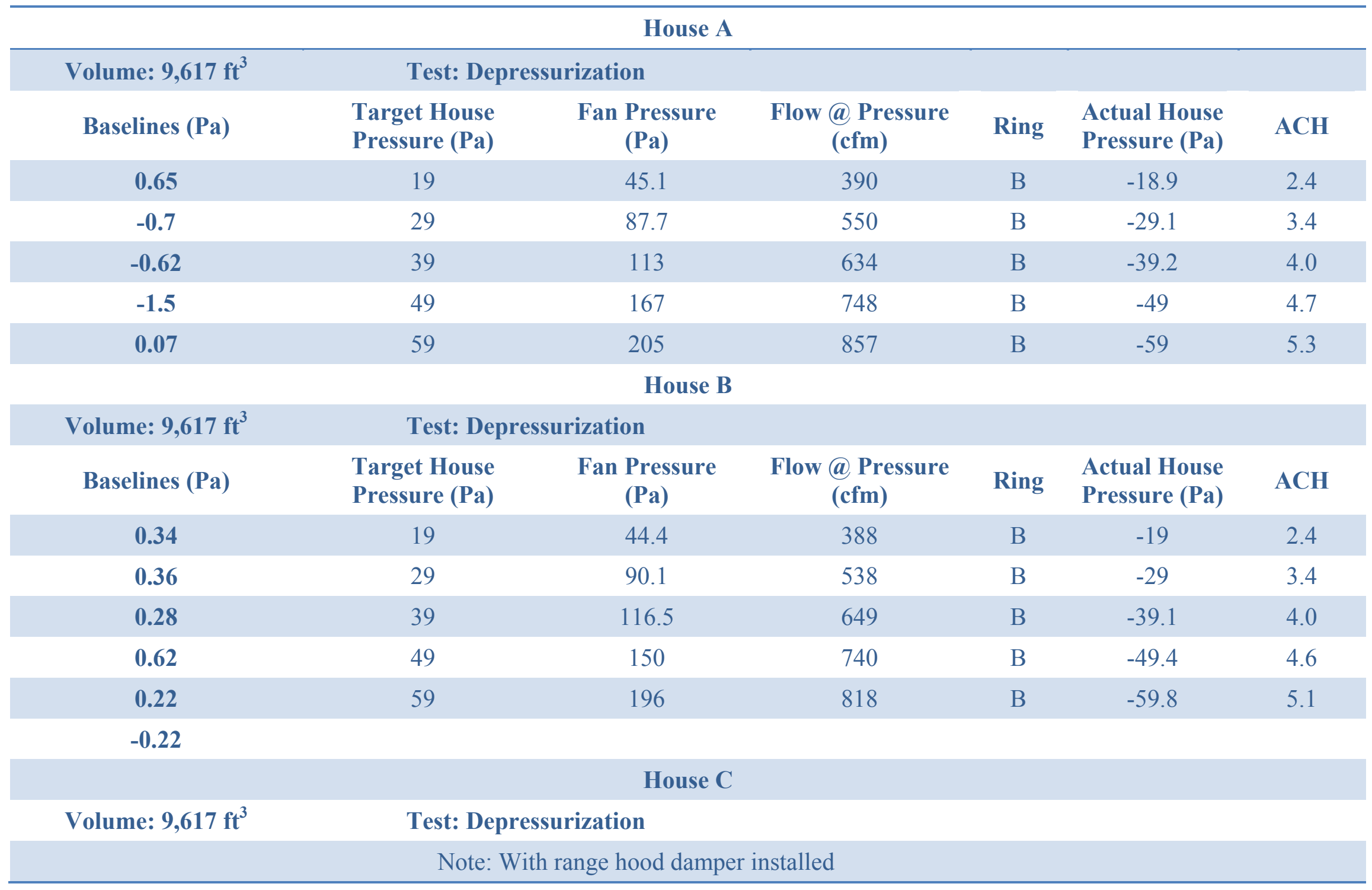




\begin{tabular}{|c|c|c|c|c|c|c|}
\hline Baselines (Pa) & $\begin{array}{l}\text { Target House } \\
\text { Pressure (Pa) }\end{array}$ & $\begin{array}{l}\text { Fan Pressure } \\
\text { (Pa) }\end{array}$ & $\begin{array}{c}\text { Flow @ Pressure } \\
\text { (cfm) }\end{array}$ & Ring & $\begin{array}{l}\text { Actual House } \\
\text { Pressure (Pa) }\end{array}$ & $\mathbf{A C H}$ \\
\hline 0.84 & 19 & 27.2 & 268 & B & -19.8 & 1.7 \\
\hline 0.19 & 29 & 41.2 & 384 & B & -29.7 & 2.4 \\
\hline-0.25 & 39 & 64.7 & 475 & B & -39 & 3.0 \\
\hline-0.4 & 49 & 106.5 & 616 & B & -48.9 & 3.8 \\
\hline-0.12 & 59 & 151 & 716 & B & -59.3 & 4.5 \\
\hline
\end{tabular}

Table 48. Transfer Fan Flows-House C

\begin{tabular}{|c|c|c|c|c|c|c|}
\hline \multirow[b]{2}{*}{ Room } & \multicolumn{2}{|c|}{$\begin{array}{c}\text { Original Fans } \\
(\text { March 30, 2014) }\end{array}$} & \multicolumn{2}{|c|}{$\begin{array}{c}\text { Original Fans } \\
\text { (July 22, 2014) }\end{array}$} & \multicolumn{2}{|c|}{$\begin{array}{c}\text { New Fans Max. Speed } \\
\text { in Master Bedroom and Bathroom } \\
\text { July 22, } 2014\end{array}$} \\
\hline & $\begin{array}{l}\text { Fan Side } \\
\quad(\mathrm{cfm})\end{array}$ & Supply (cfm) & Fan Side (cfm) & Supply (cfm) & Fan Side (cfm) & Supply (cfm) \\
\hline $\begin{array}{l}\text { Master } \\
\text { Bedroom }\end{array}$ & 66 & 48 & 57 & 45 & 133 & 106 \\
\hline $\begin{array}{c}\text { Master } \\
\text { Bathroom }\end{array}$ & 51 & 48 & 51 & 45 & 125 & 115 \\
\hline $\begin{array}{l}\text { Northwest } \\
\text { Bedroom }\end{array}$ & 42 & 38 & Not measured & 37 & N/A & N/A \\
\hline $\begin{array}{l}\text { Northeast } \\
\text { Bedroom }\end{array}$ & 56 & 48 & 55 & 49 & N/A & N/A \\
\hline
\end{tabular}




\section{Appendix B: Monitoring Points and Equipment}

Table 49. Inventory of Monitoring Equipment, Data Loggers, and Sensors

\begin{tabular}{|c|c|c|c|c|c|c|}
\hline Quantity & $\begin{array}{l}\text { Description/ } \\
\text { Purpose }\end{array}$ & $\begin{array}{l}\text { Make and Model of } \\
\text { Monitoring Equipment } \\
\text { (or Equal) }\end{array}$ & $\mathbf{A}$ & B & $\mathbf{C}$ & Outdoors \\
\hline 3 & & $\begin{array}{l}\text { Campbell Scientific data } \\
\text { logger, model: CR1000 }\end{array}$ & 1 & 1 & 1 & \\
\hline 3 & Data logging equipment & $\begin{array}{l}\text { Campbell Scientific data } \\
\text { logger, power supply }\end{array}$ & 1 & 1 & 1 & \\
\hline 3 & & $\begin{array}{c}\text { Campbell Scientific, } \\
\text { multiplexer model: } \\
\text { AM16/32B }\end{array}$ & 1 & 1 & 1 & \\
\hline 15 & $\begin{array}{l}\text { Air temperature } \\
\text { measurement }\end{array}$ & Watlow thermocouples & 5 & 5 & 5 & \\
\hline 2 & $\begin{array}{l}\text { Electric furnace power } \\
\qquad(100 \mathrm{amps})\end{array}$ & $\begin{array}{l}\text { Continental Control } \\
\text { Systems, } \\
\text { ACT-0750-100 }\end{array}$ & 2 & & & \\
\hline 7 & $\begin{array}{l}\text { Air temperature/ } \\
\text { relative humidity }\end{array}$ & Campbell CS215 probe & 1 & 4 & 1 & 1 \\
\hline 19 & $\begin{array}{l}\text { Protection for outdoor air } \\
\text { temperature and relative } \\
\text { humidity sensor }\end{array}$ & $\begin{array}{c}\text { Campbell Scientific, 41303- } \\
\text { 5A radiation shield }\end{array}$ & 6 & 6 & 6 & 1 \\
\hline 1 & Solar radiation sensor & $\begin{array}{c}\text { Campbell LI200X-L silicon } \\
\text { pyranometer }\end{array}$ & & & & 1 \\
\hline 4 & Moisture content of wood & Omnisense S900-1 & & 2 & 2 & \\
\hline 6 & $\begin{array}{c}\text { Compressor and fan current } \\
\text { measurements }\end{array}$ & Veris, H721LC (10 amps) & 2 & 2 & 2 & \\
\hline 2 & $\begin{array}{l}\text { Status heat pump reversing } \\
\text { valve }\end{array}$ & Veris, H300 & & 1 & 1 & \\
\hline 6 & $\begin{array}{c}\text { Heat pump/ } \\
\text { AC power (20 amps) }\end{array}$ & $\begin{array}{l}\text { Continental Control } \\
\text { Systems, } \\
\text { ACT-0750-20 }\end{array}$ & 2 & 2 & 2 & \\
\hline 6 & $\begin{array}{l}\text { Total house power } \\
\qquad(150 \text { amps })\end{array}$ & $\begin{array}{l}\text { Continental Control } \\
\text { Systems, } \\
\text { ACT-0750-150 }\end{array}$ & 2 & 2 & 2 & \\
\hline 7 & Wattnode power meter & $\begin{array}{c}\text { Continental Control } \\
\text { Systems, WNB-3Y-208-P }\end{array}$ & 3 & 2 & 2 & \\
\hline
\end{tabular}




\begin{tabular}{|c|c|c|c|c|c|c|}
\hline Quantity & $\begin{array}{l}\text { Description/ } \\
\text { Purpose }\end{array}$ & $\begin{array}{c}\text { Make and Model of } \\
\text { Monitoring Equipment } \\
\text { (or Equal) }\end{array}$ & $\mathbf{A}$ & B & $\mathbf{C}$ & Outdoors \\
\hline 1 & Bath fan run time & Veris, H300 & & & 1 & \\
\hline 1 & $\begin{array}{l}\text { Electric furnace resistance } \\
\text { element status }\end{array}$ & Veris, H300 & & 1 & & \\
\hline 3 & $\begin{array}{l}\text { Serial-to-Ethernet interface } \\
\text { for wireless communication }\end{array}$ & Campbell Scientific, NL201 & 1 & 1 & 1 & \\
\hline 4 & $\begin{array}{l}\text { Monitor run time of through- } \\
\text { wall air transfer fans }\end{array}$ & Veris, H300 & & & 4 & \\
\hline
\end{tabular}




\section{Appendix C: Impacts of Transfer Fans}

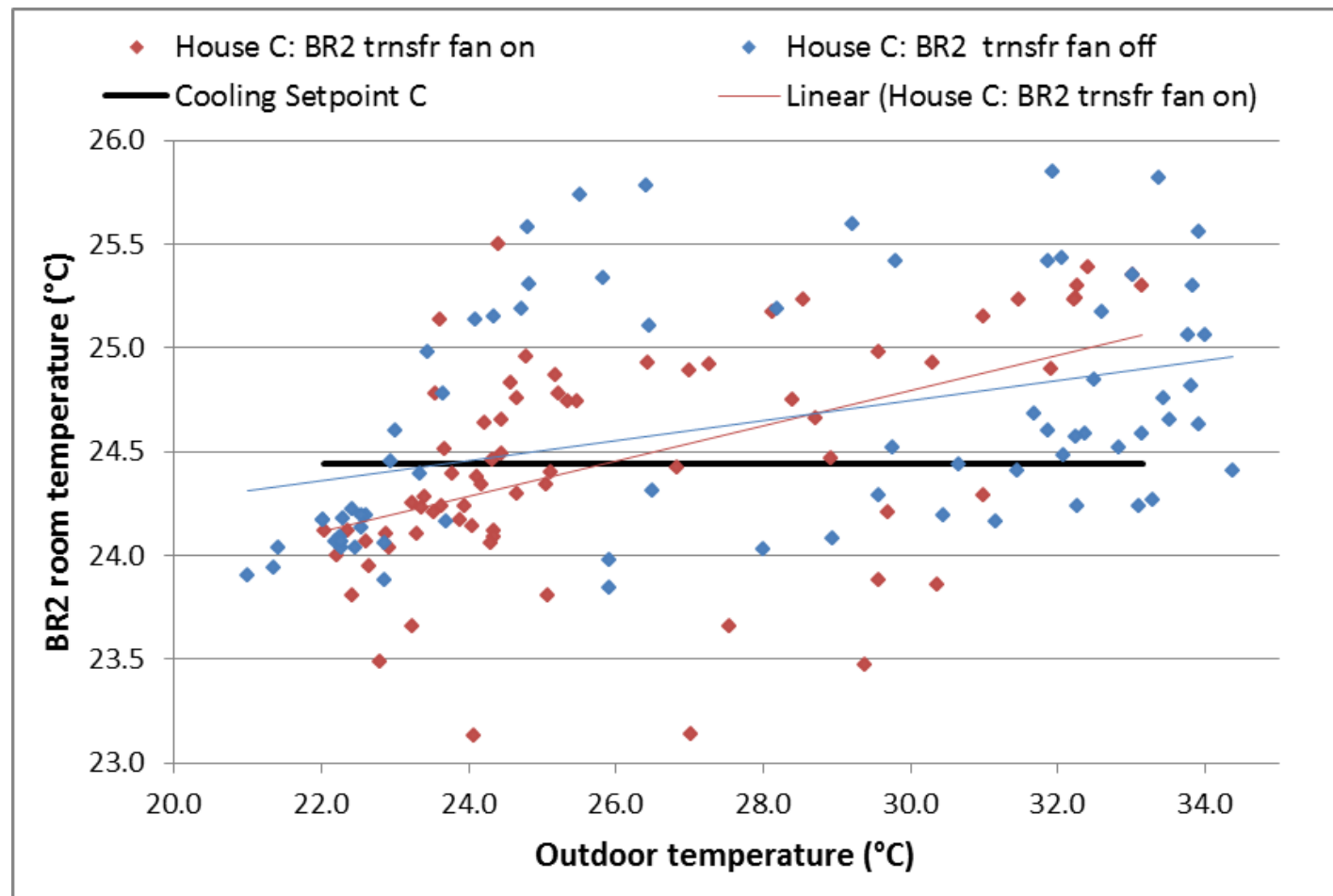

Figure 43. House $C$ Bedroom 2 temperatures with and without transfer fan operation (cooling season) 


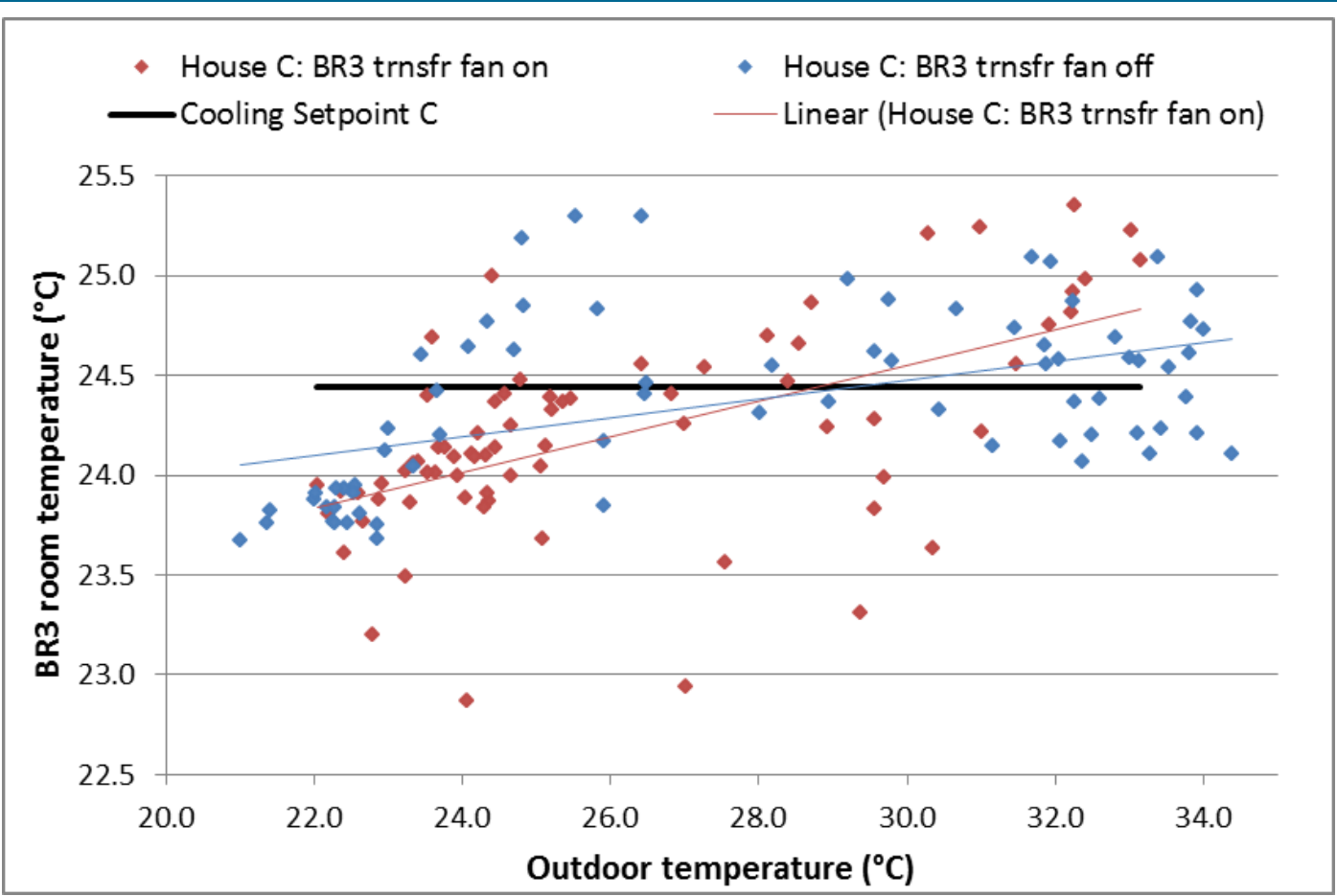

Figure 44. House $C$ Bedroom 3 temperatures with and without transfer fan operation (cooling season) 
- House C: Living trnsfr fan on Cooling Setpoint C

- Linear (House C: Living trnsfr fan off)

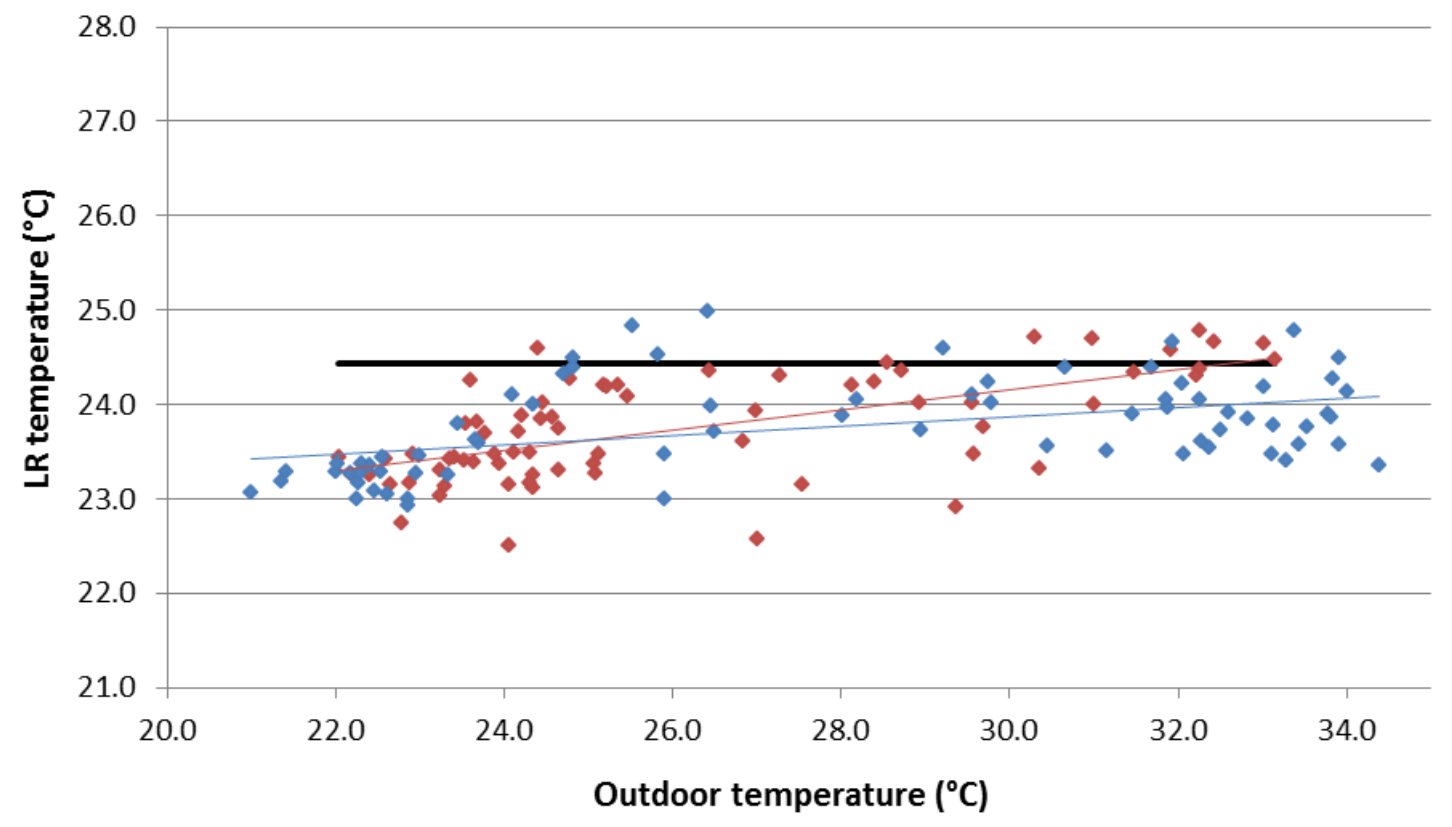

Figure 45. House $\mathrm{C}$ living room temperatures with and without transfer fan operation (cooling season) 


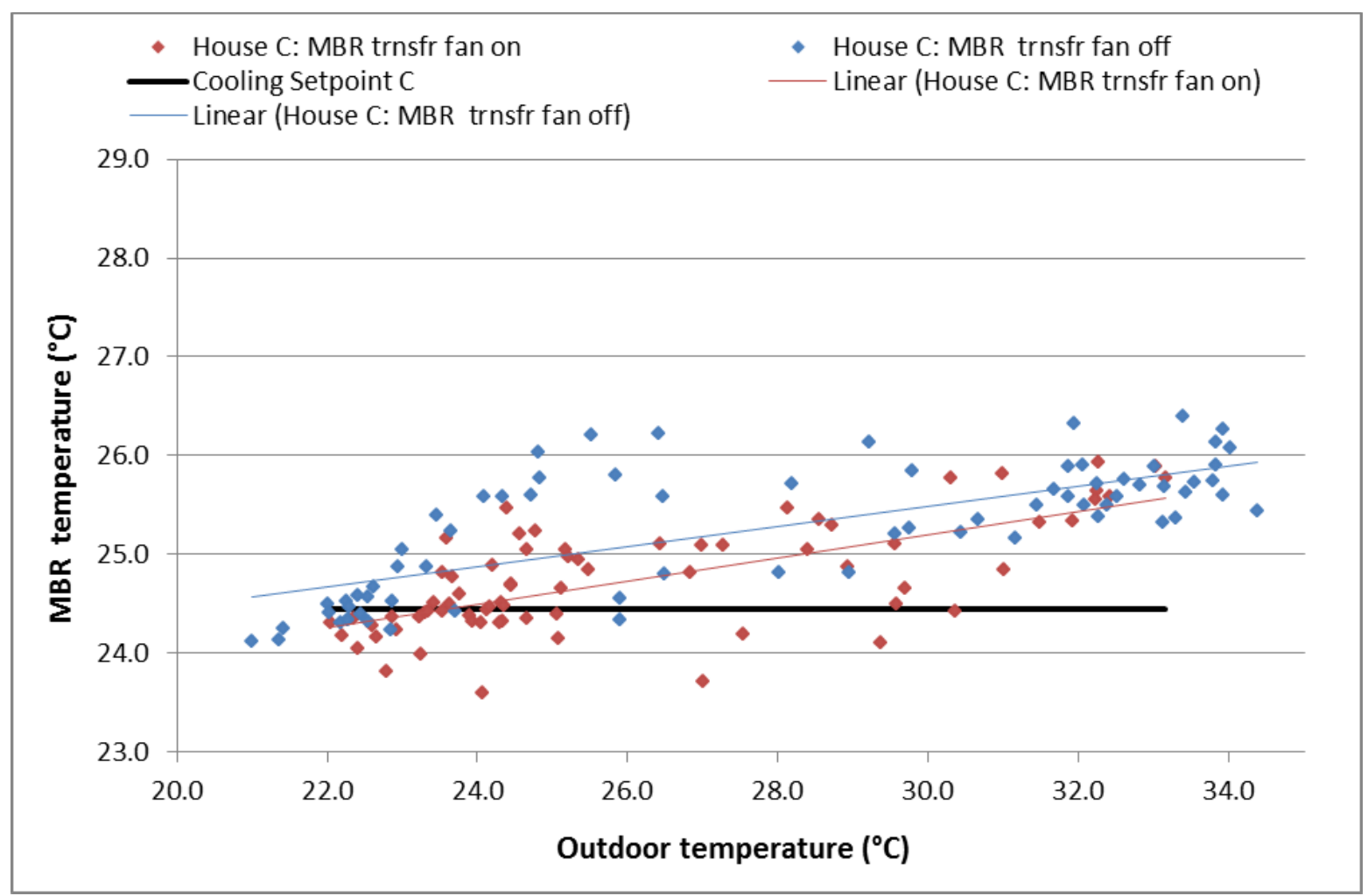

Figure 46. House $\mathrm{C}$ master bedroom temperatures with and without transfer fan operation (cooling season)

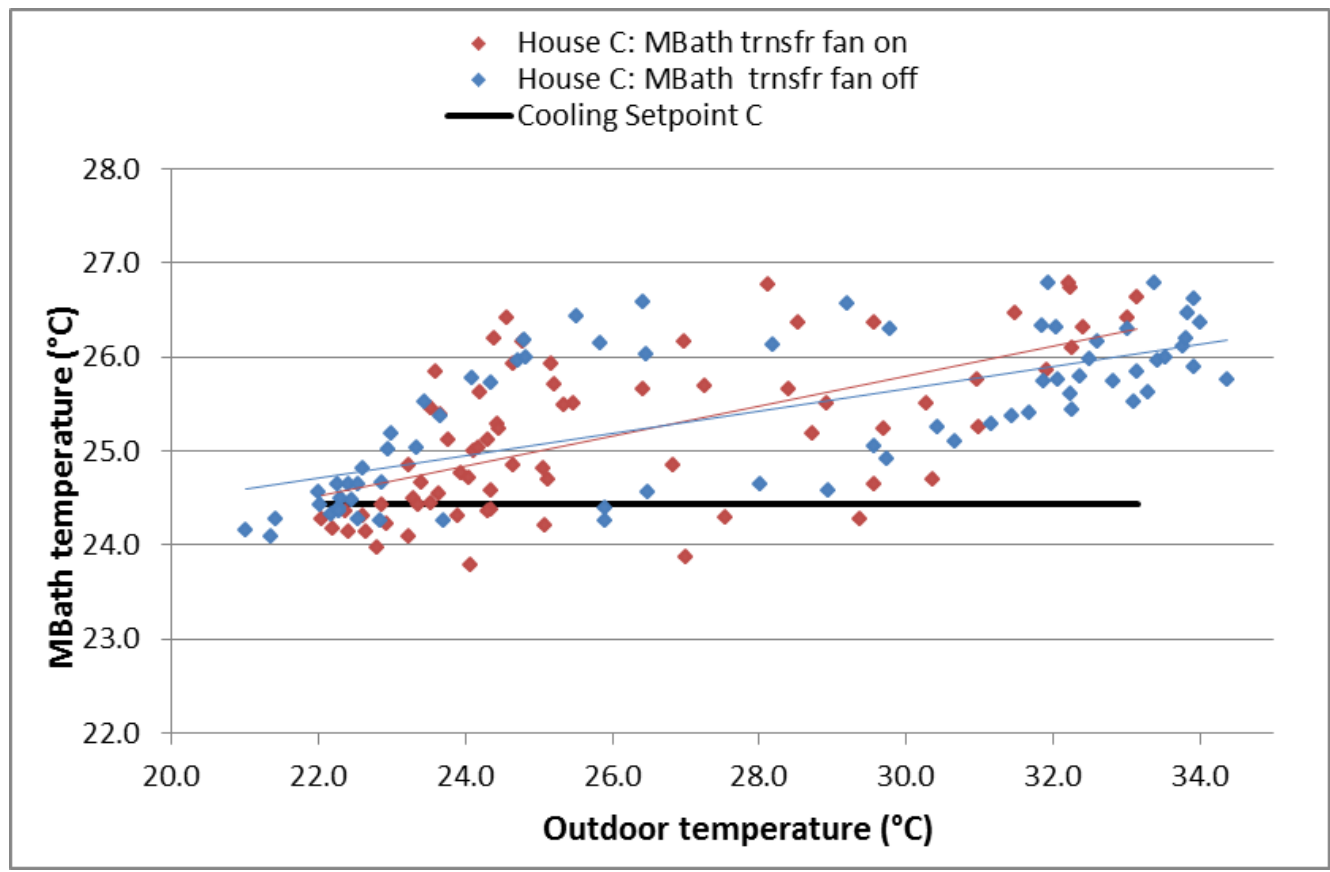

Figure 47. House $\mathrm{C}$ master bathroom temperatures with and without transfer fan operation (cooling season) 


\section{Appendix D: Impacts of Blind Position}

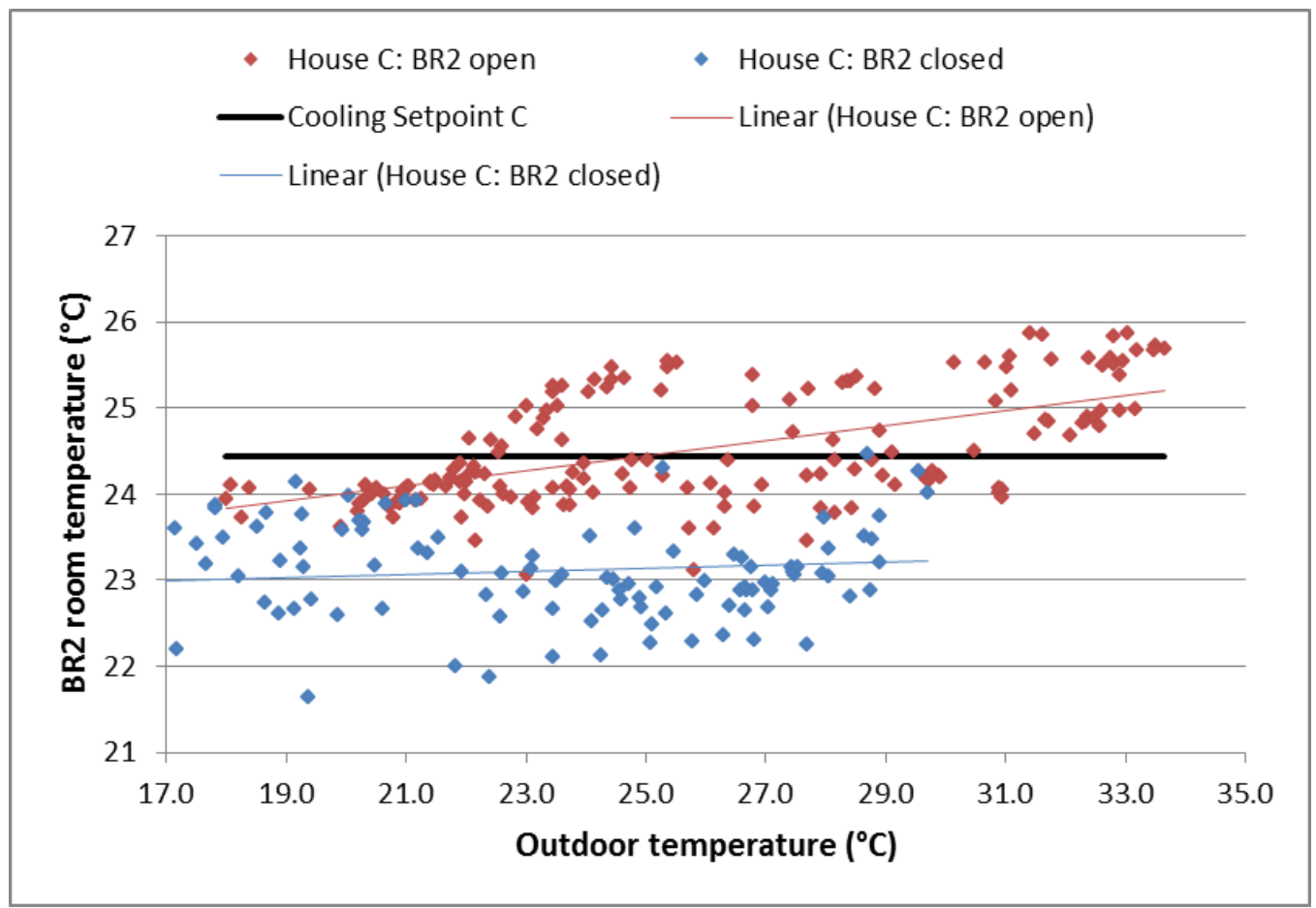

Figure 48. House $C$ impacts of blind position in Bedroom 2 on room temperature compared to outdoor temperature (cooling season) 


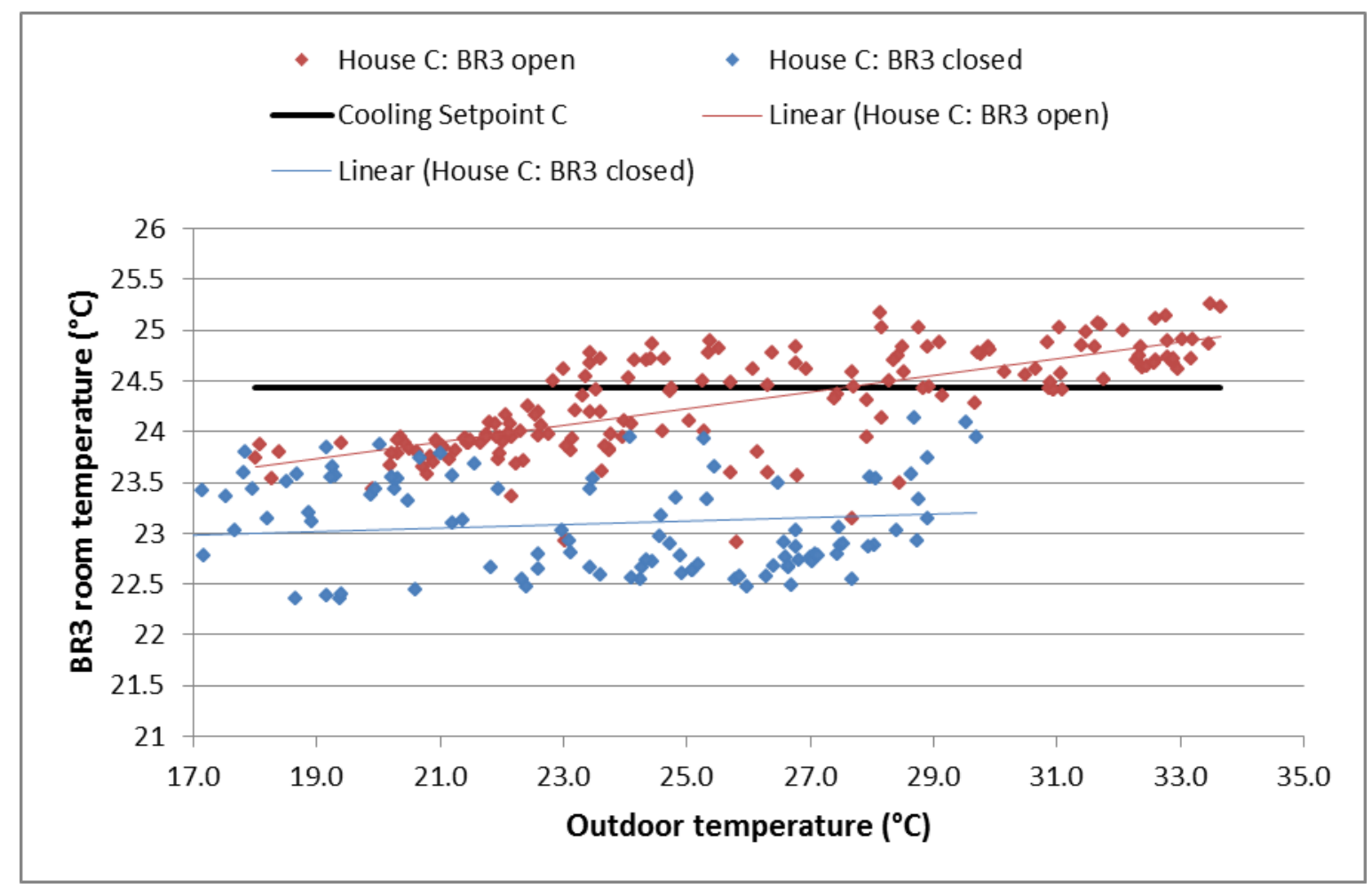

Figure 49. House $\mathrm{C}$ impacts of blind position on Bedroom 3 on room temperature compared to outdoor temperature (cooling season) 


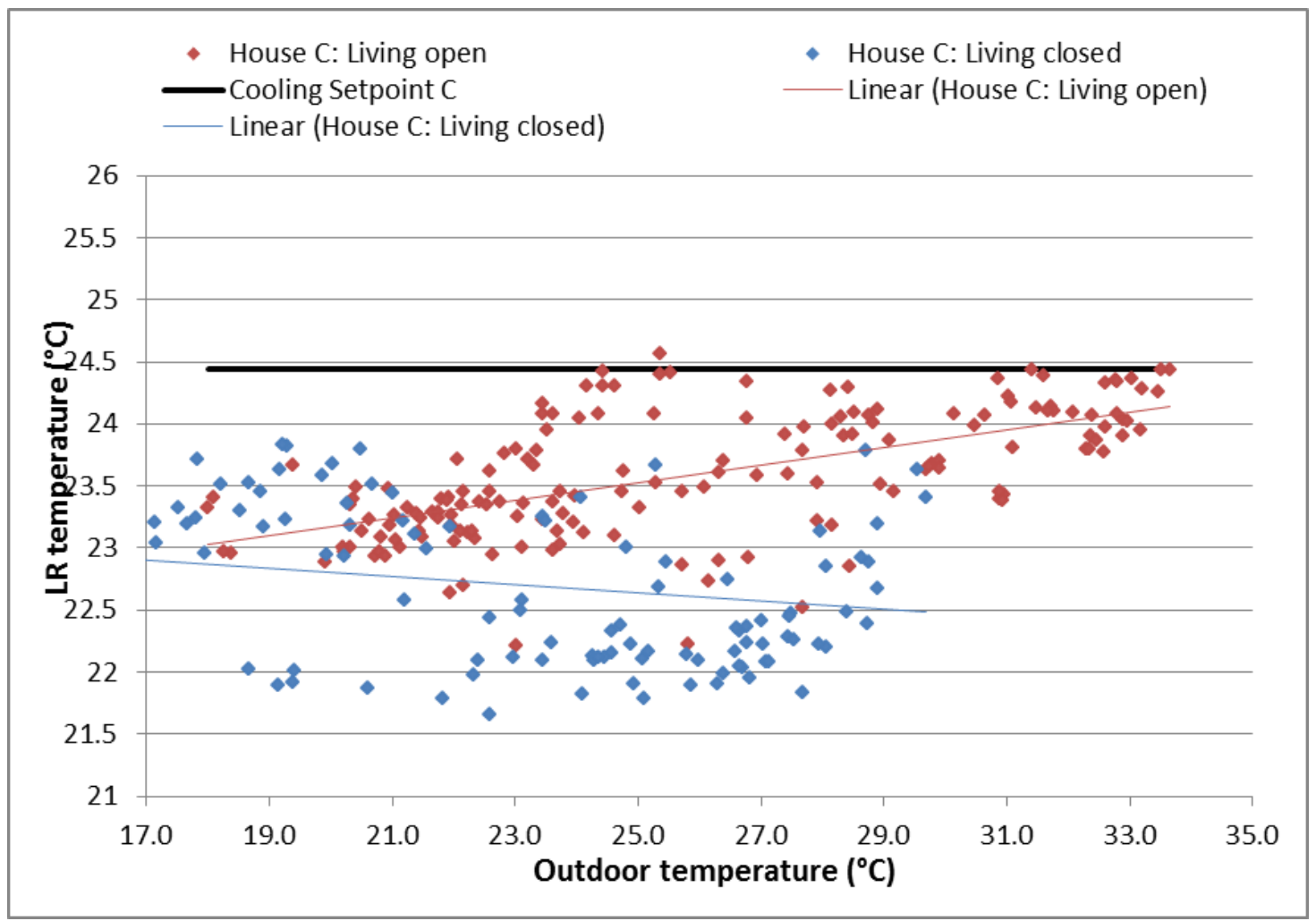

Figure 50. House $\mathrm{C}$ impacts of blind position on living room temperature compared to outdoor temperature (cooling season) 


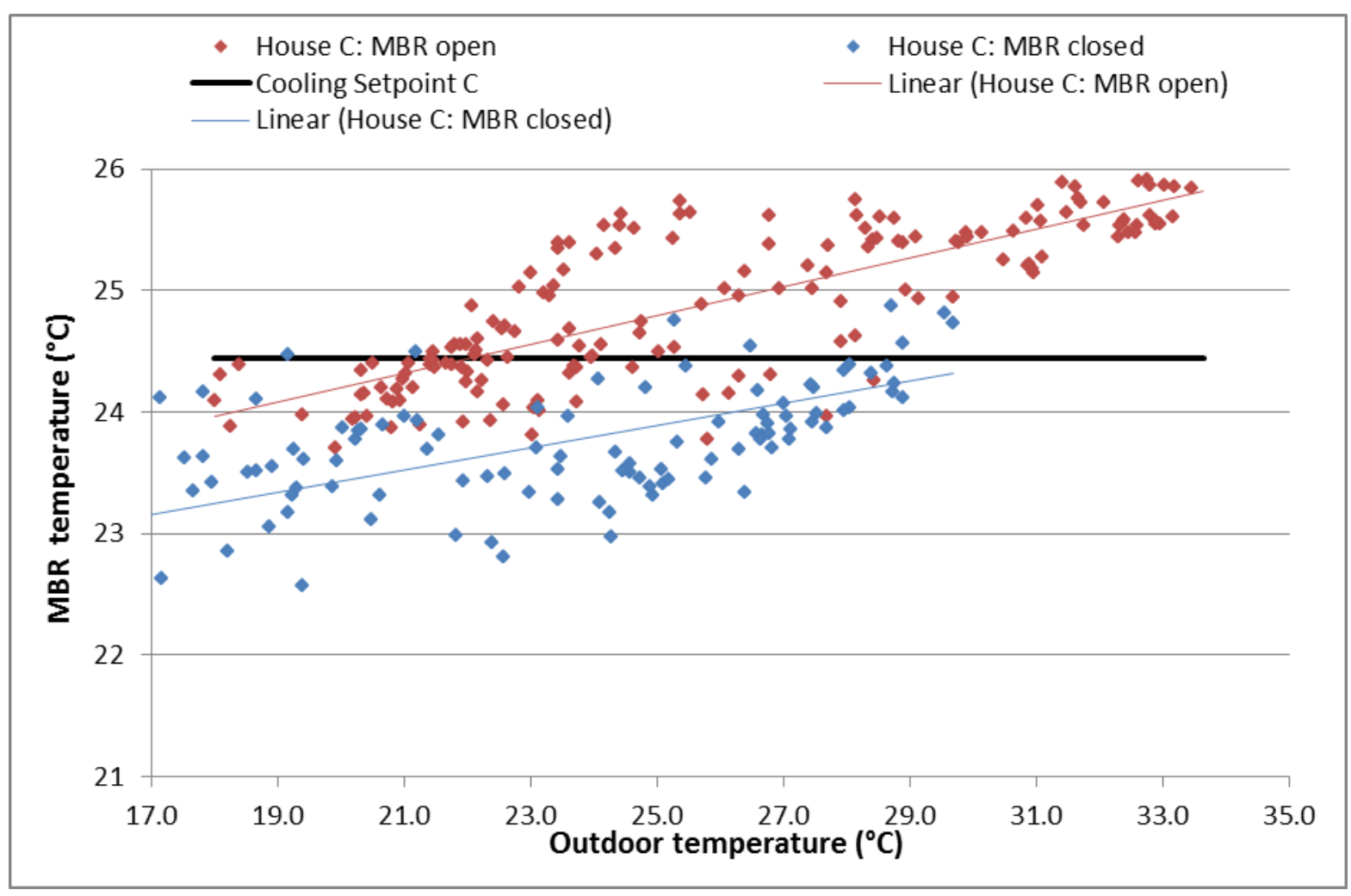

Figure 51. House $C$ impacts of blind position on master bedroom temperature compared to outdoor temperature (cooling season) 


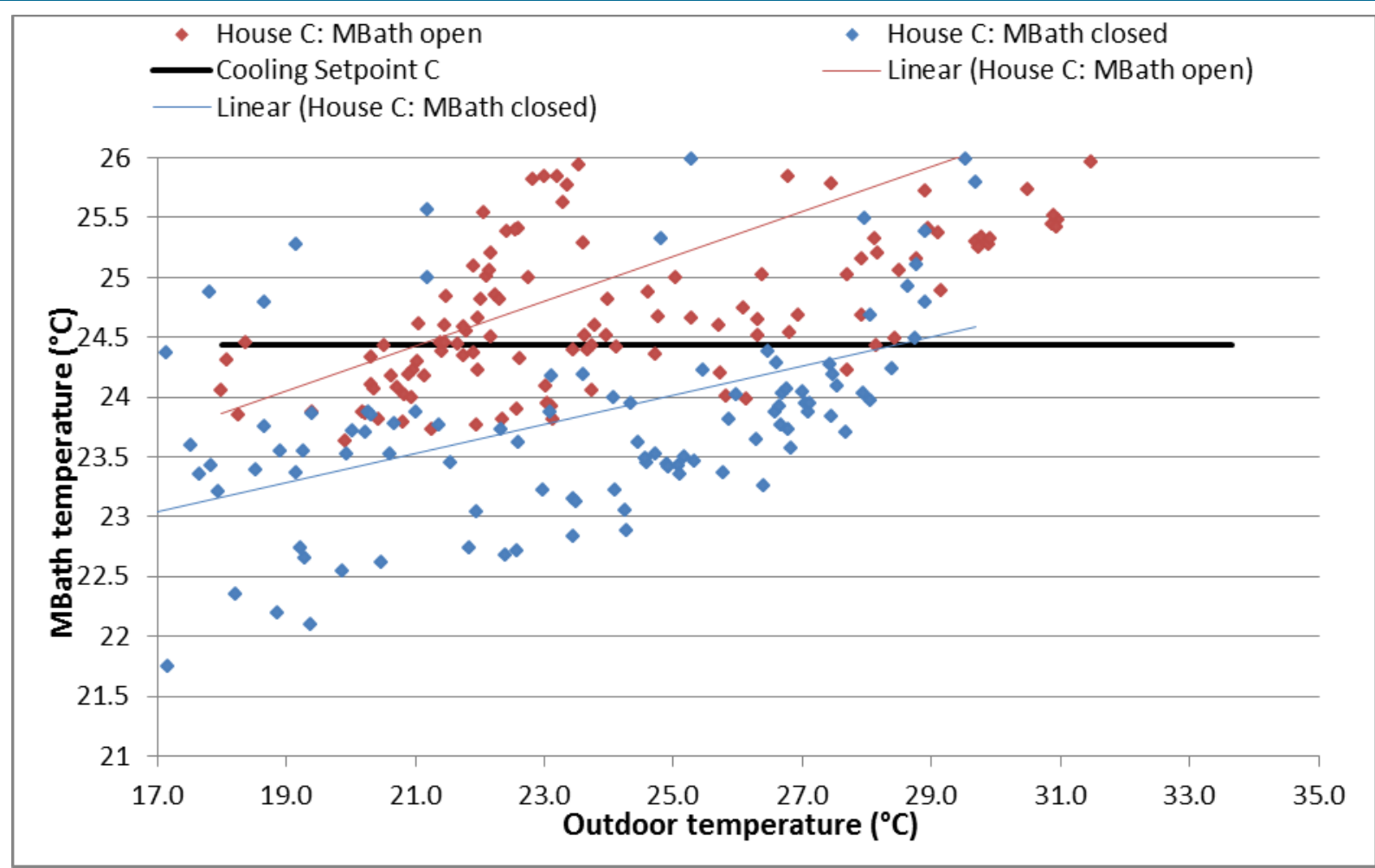

Figure 52. House $C$ impacts of blind position on master bathroom temperature compared to outdoor temperature (cooling season) 


\section{Appendix E: Impacts of Door Position}

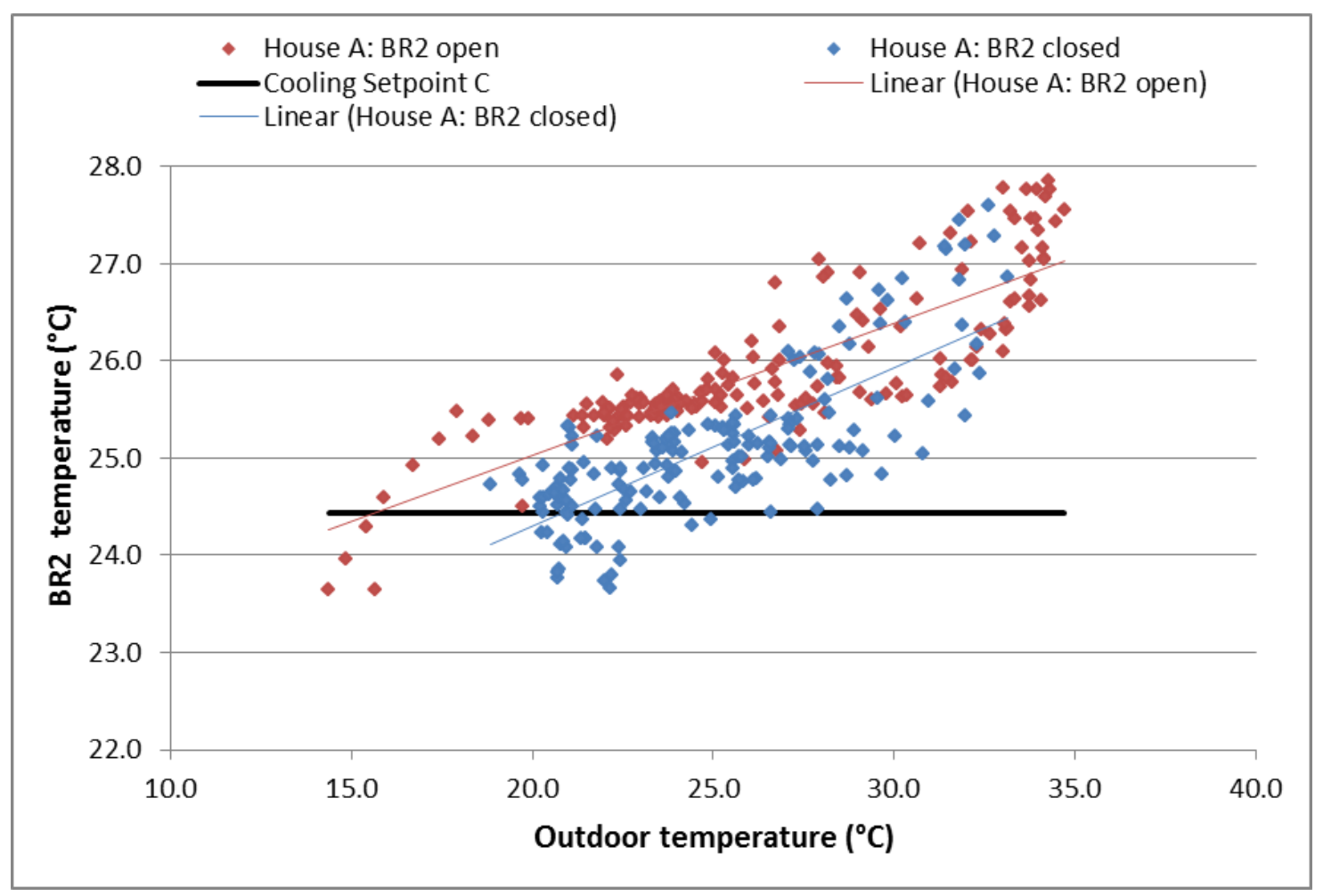

Figure 53. House A impacts of door position on Bedroom 2 temperature compared to outdoor temperature $\left(0.8 \mathrm{cfm} / \mathrm{ft}^{2}\right)$ (cooling season) 


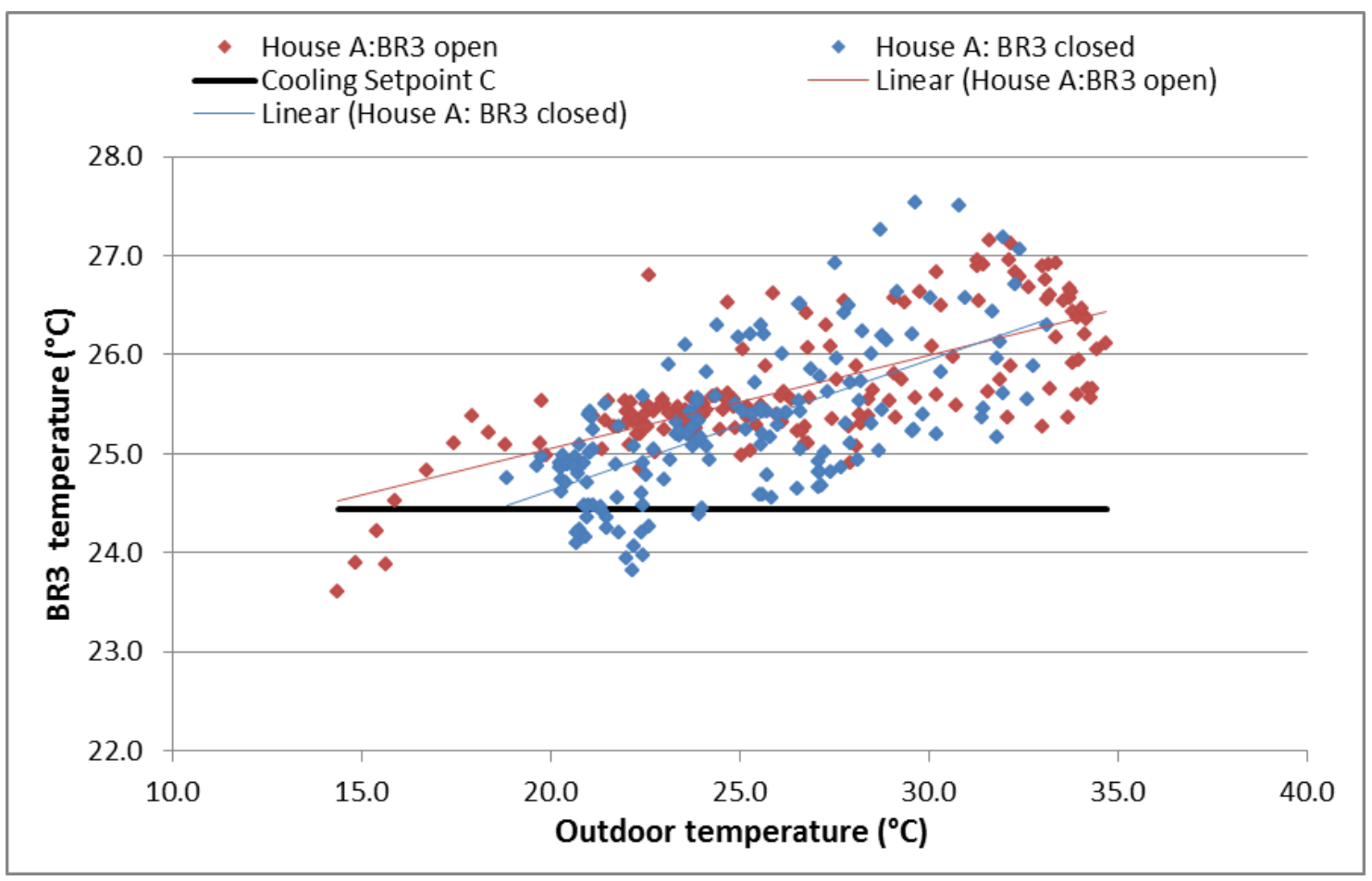

Figure 54. House A impacts of door position on Bedroom 3 temperature compared to outdoor temperature $\left(1 \mathrm{cfm} / \mathrm{ft}^{2}\right)$ (cooling season) 


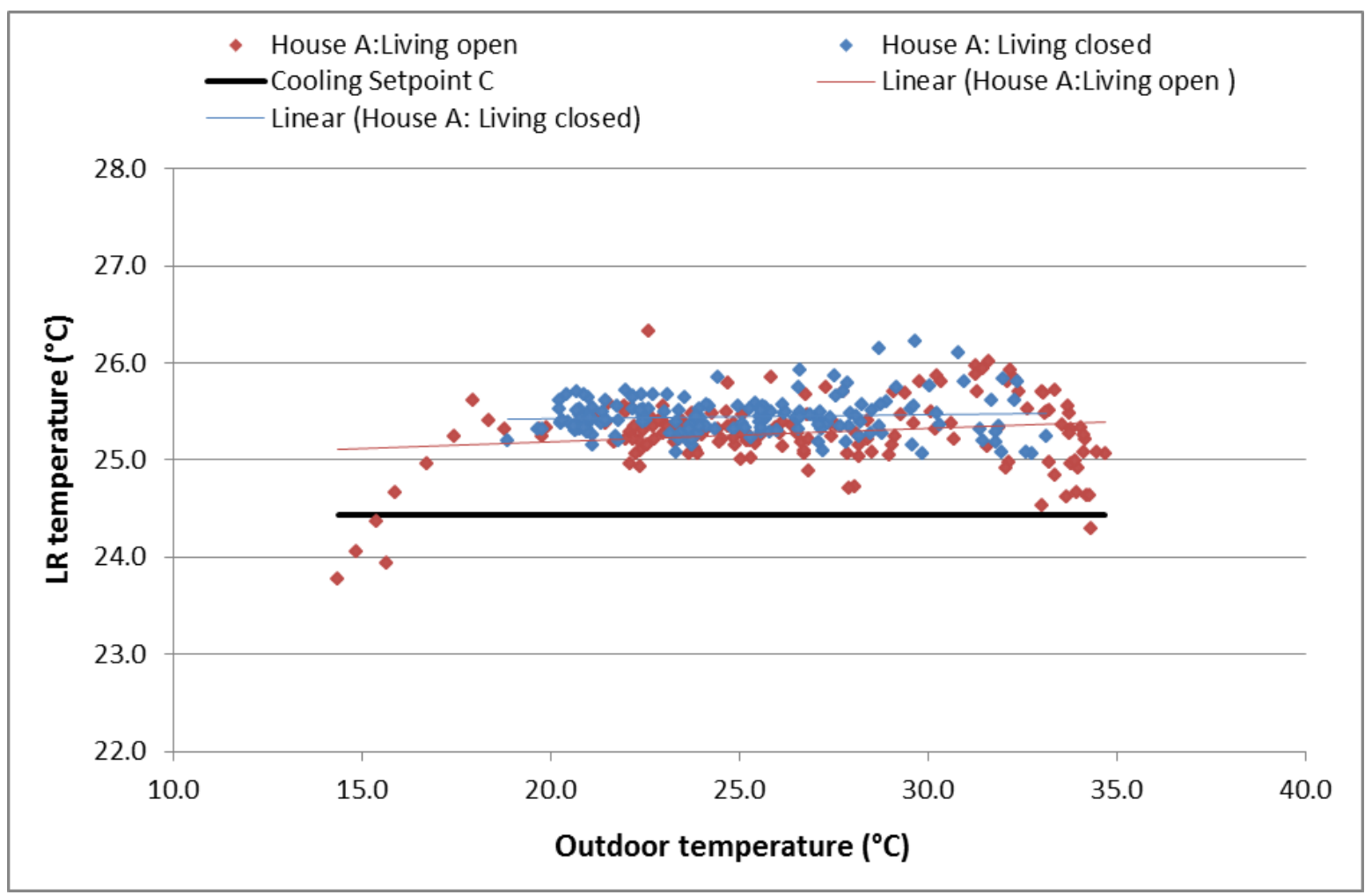

Figure 55. House A impacts of door position on living room temperature compared to outdoor temperature (cooling season) 


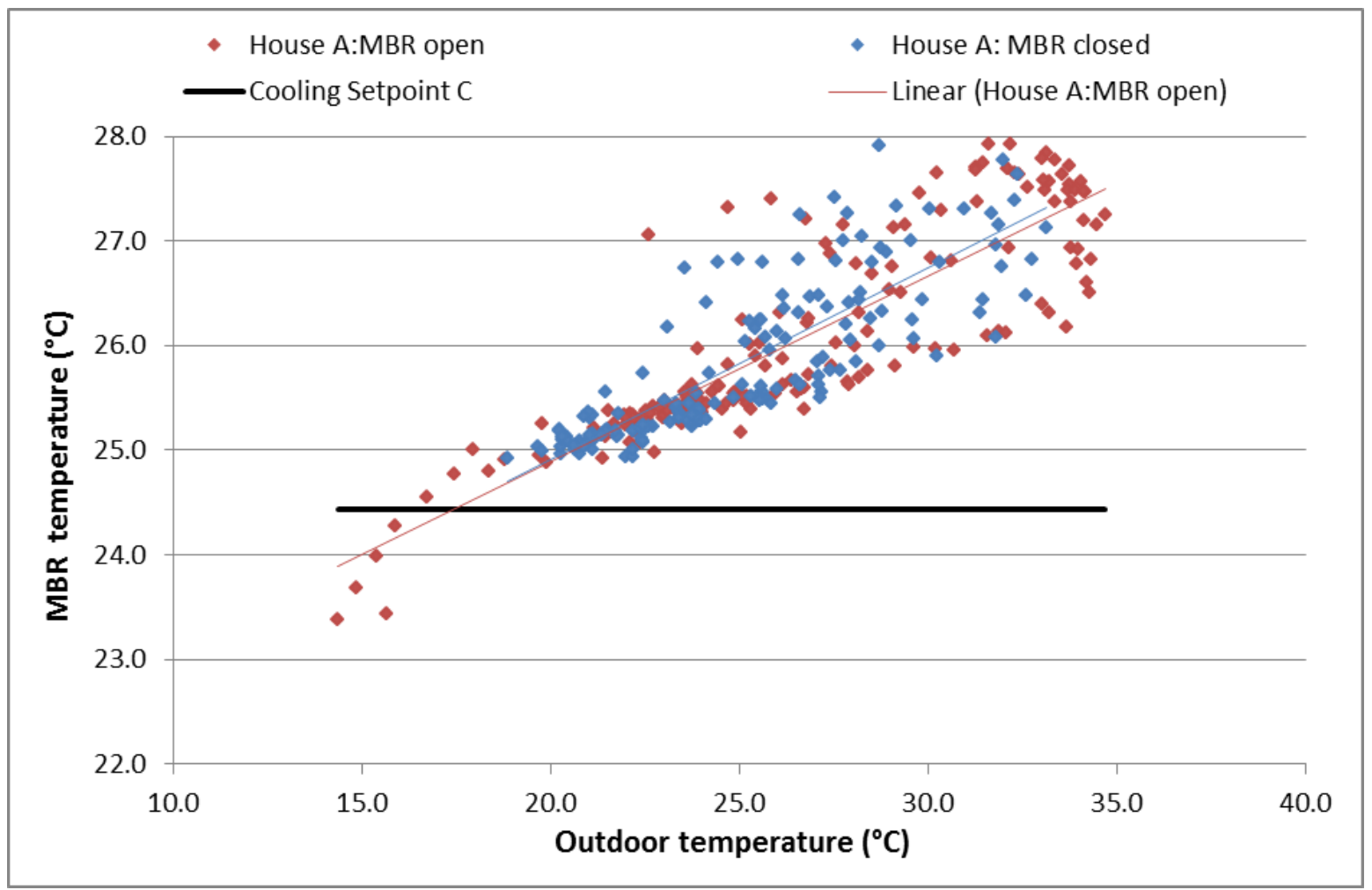

Figure 56. House A impacts of door position on master bedroom temperature compared to outdoor temperature $\left(0.5 \mathrm{cfm} / \mathrm{ft}^{2}\right)$ (cooling season) 


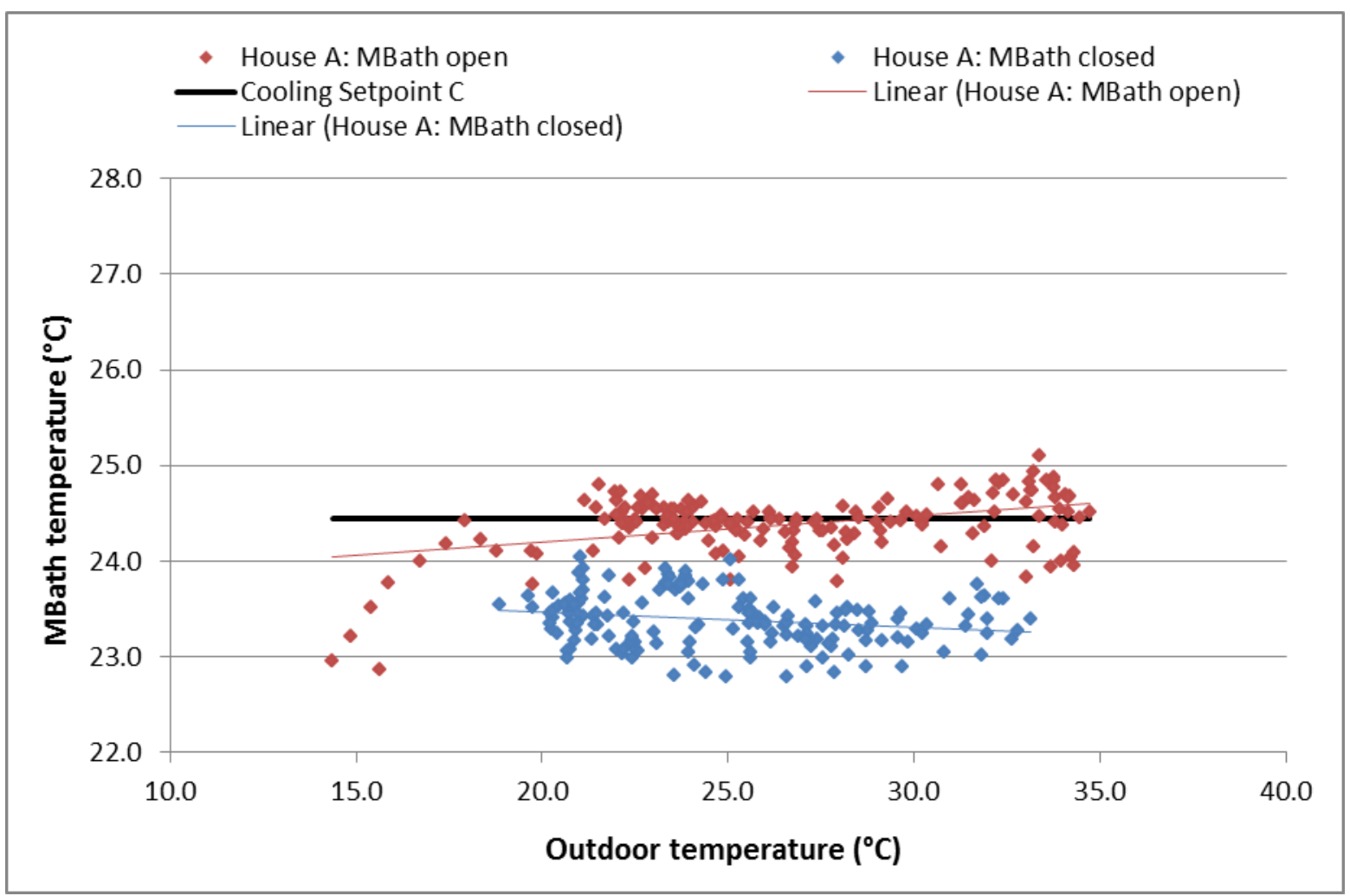

Figure 57. House A impacts of door position on master bathroom temperature compared to outdoor temperature (1.2 cfm/ft ${ }^{2}$ ) (cooling season) 


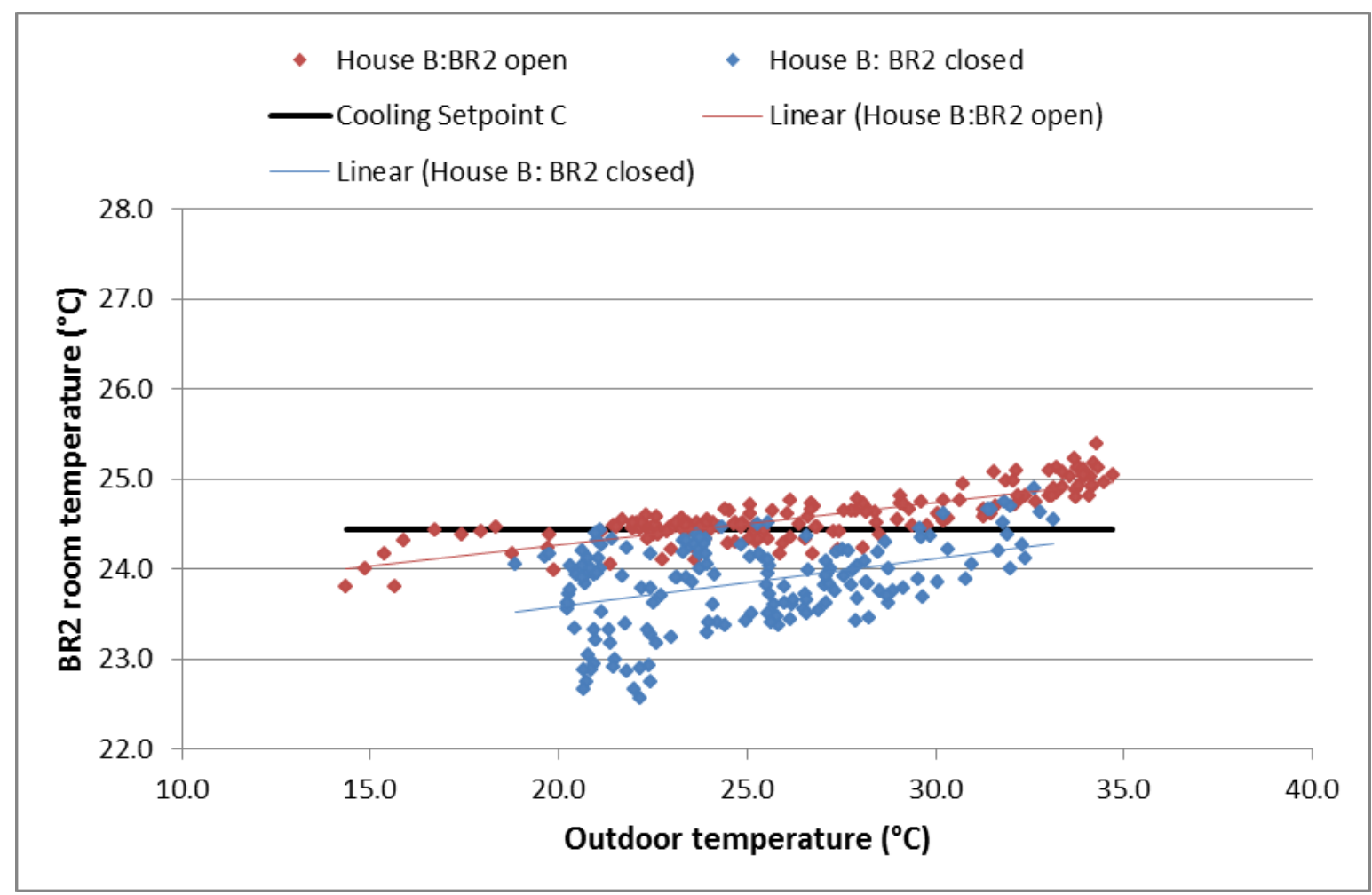

Figure 58. House B impacts of door position on Bedroom 2 room temperature compared to outdoor temperature $\left(0.7 \mathrm{cfm} / \mathrm{ft}^{2}\right)$ (cooling season) 


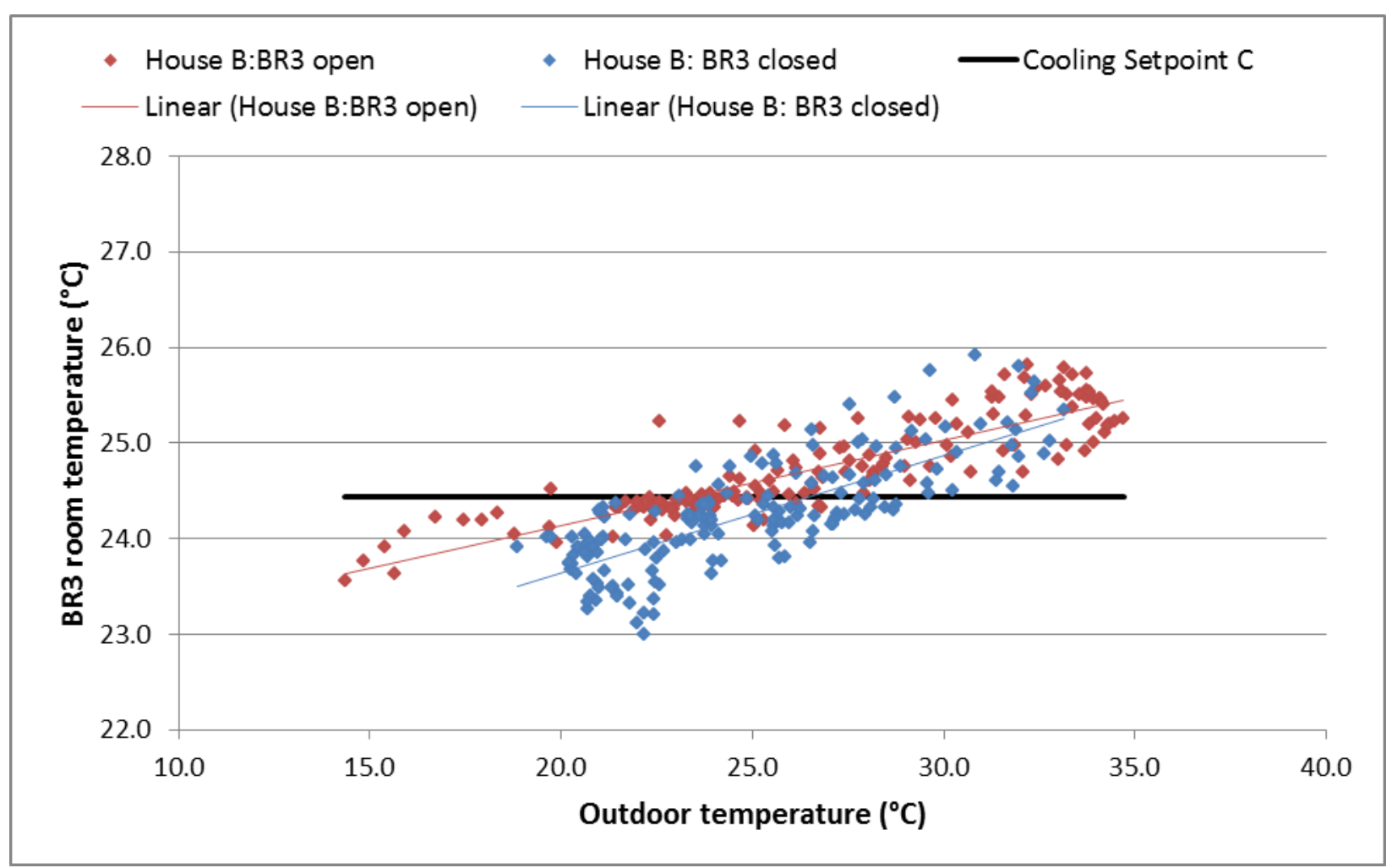

Figure 59. House B impacts of door position on Bedroom 3 room temperature compared to outdoor temperature $\left(0.8 \mathrm{cfm} / \mathrm{ft}^{2}\right)$ (cooling season) 


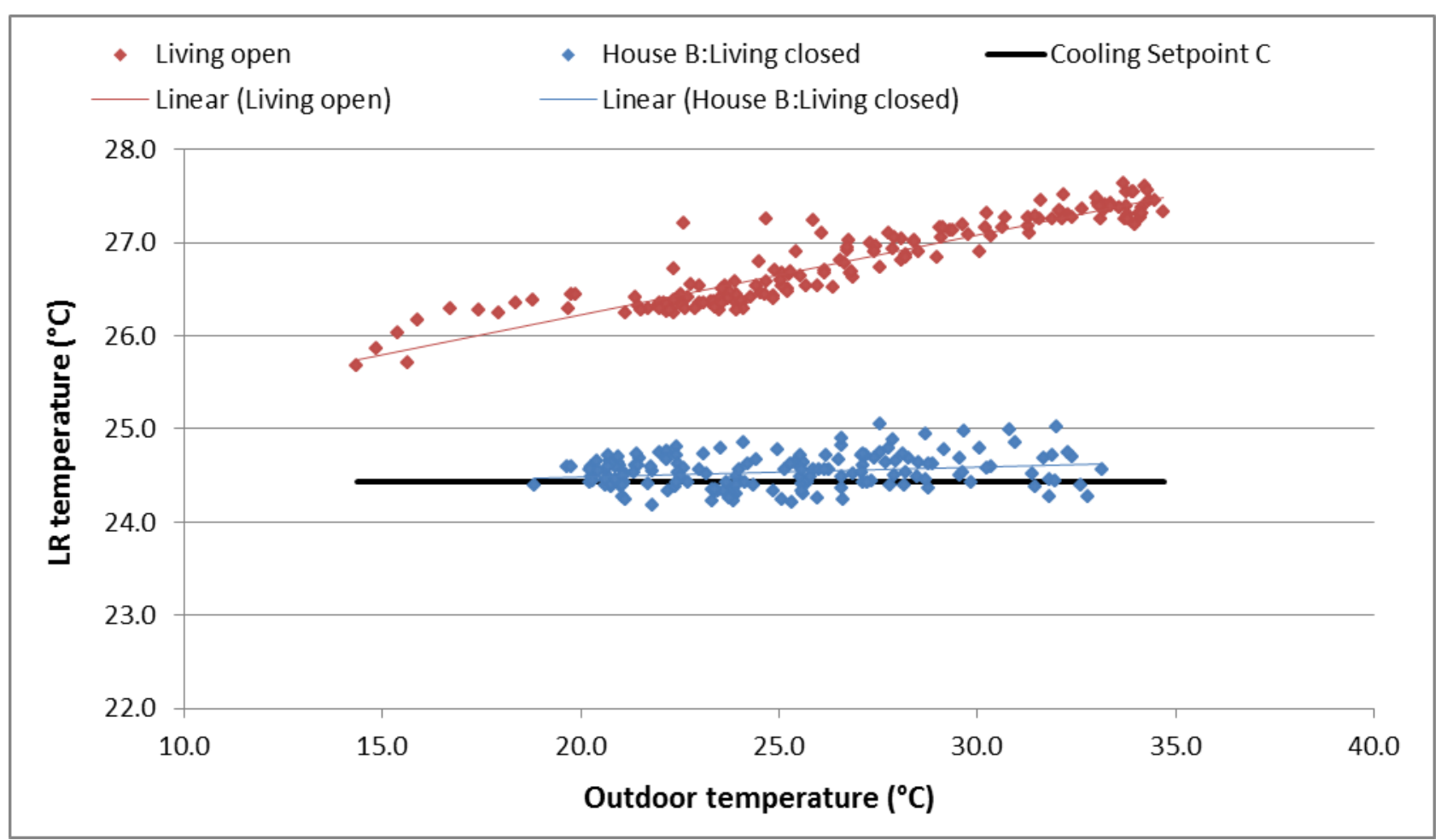

Figure 60. House B impacts of door position on living room temperature compared to outdoor temperature-aspirator failure open period (cooling season) 


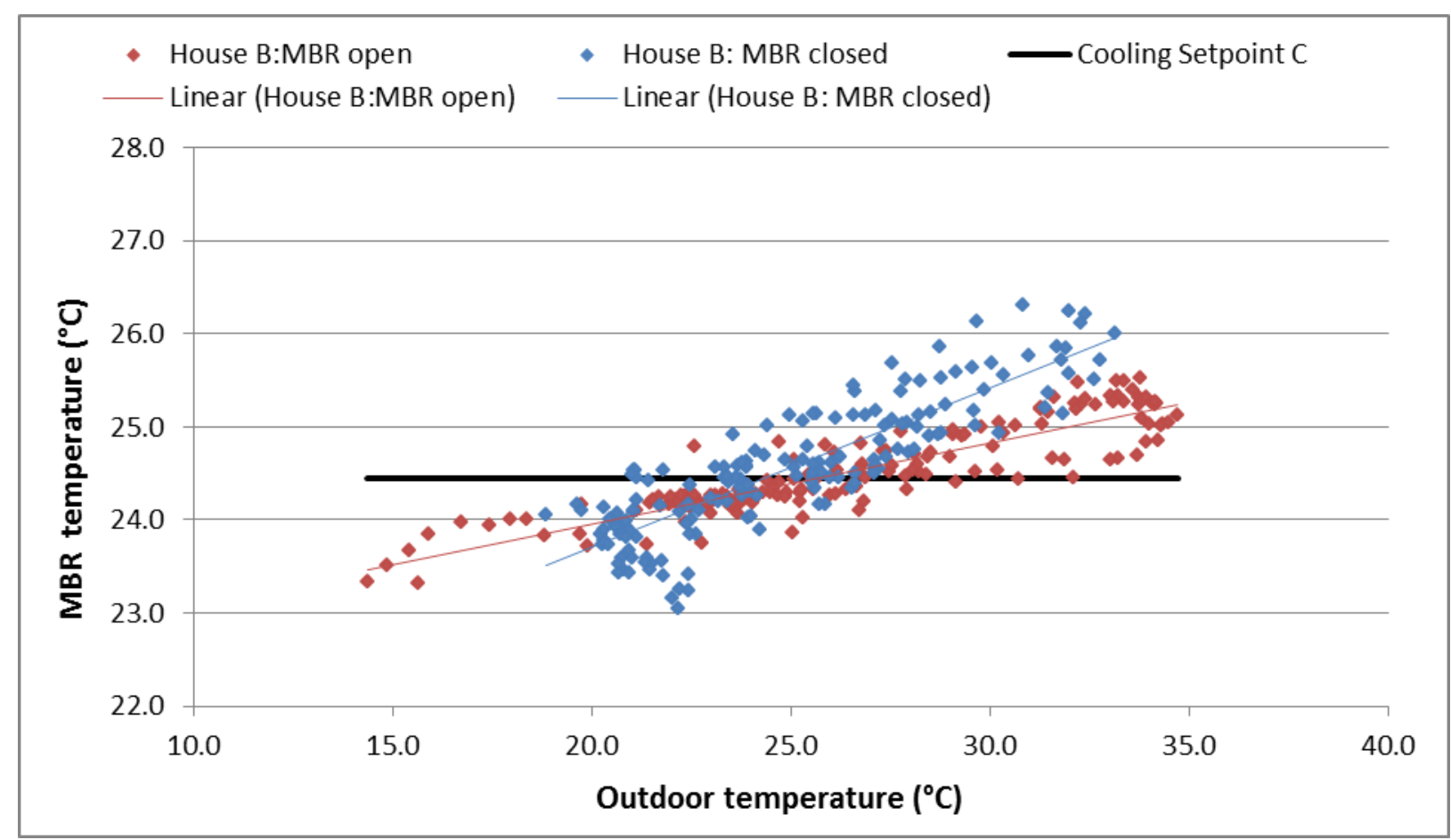

Figure 61. House B impacts of door position on master bedroom temperature compared to outdoor temperature ( $0.5 \mathrm{cfm} / \mathrm{ft}^{2}$ ) (cooling season) 


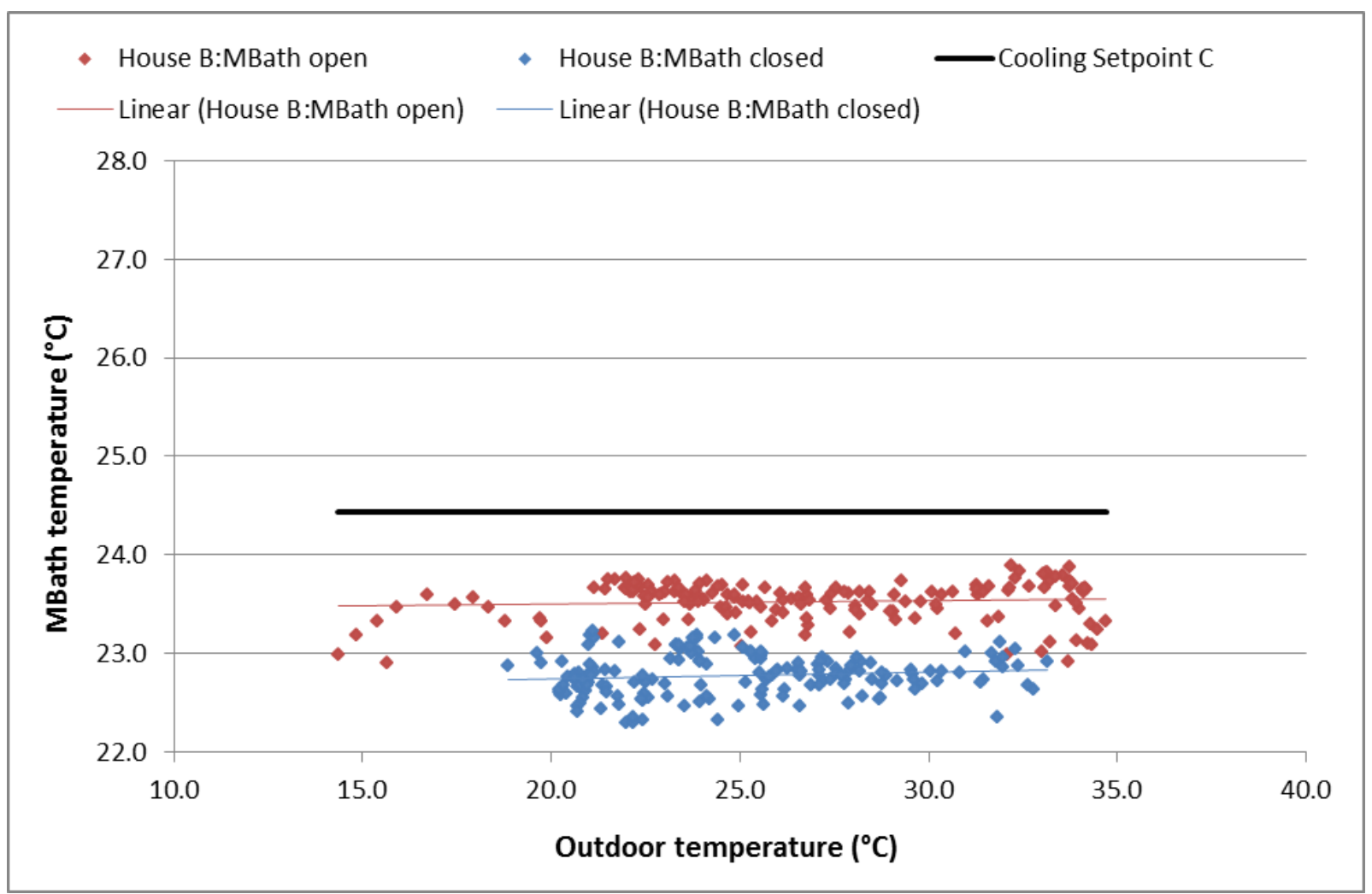

Figure 62. House B impacts of door position on master bathroom temperature compared to outdoor temperature (1.2 cfm/ $\mathrm{ft}^{2}$ ) (cooling season) 


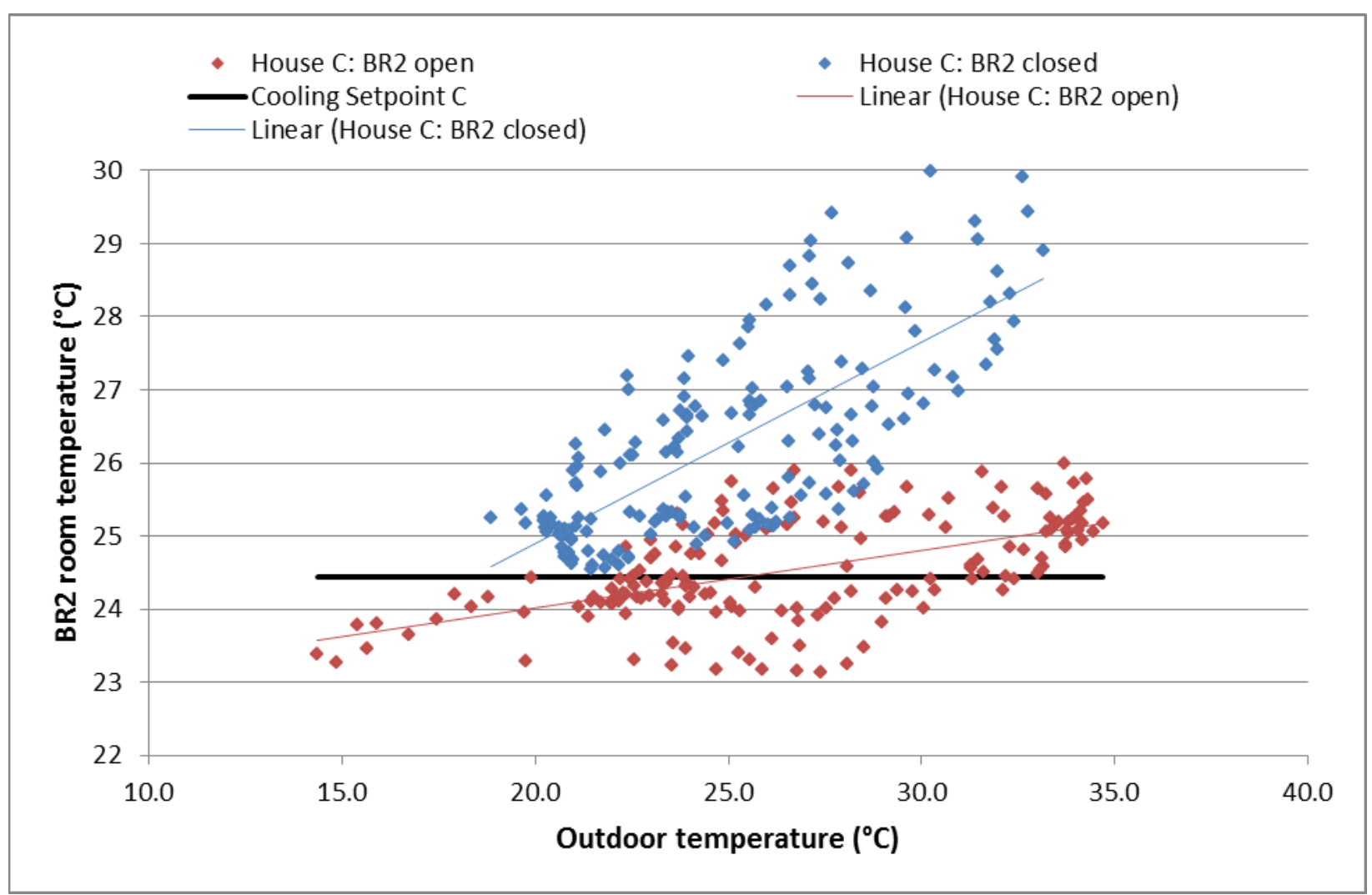

Figure 63. House C impacts of door position on Bedroom 2 room temperature compared to outdoor temperature (cooling season) 


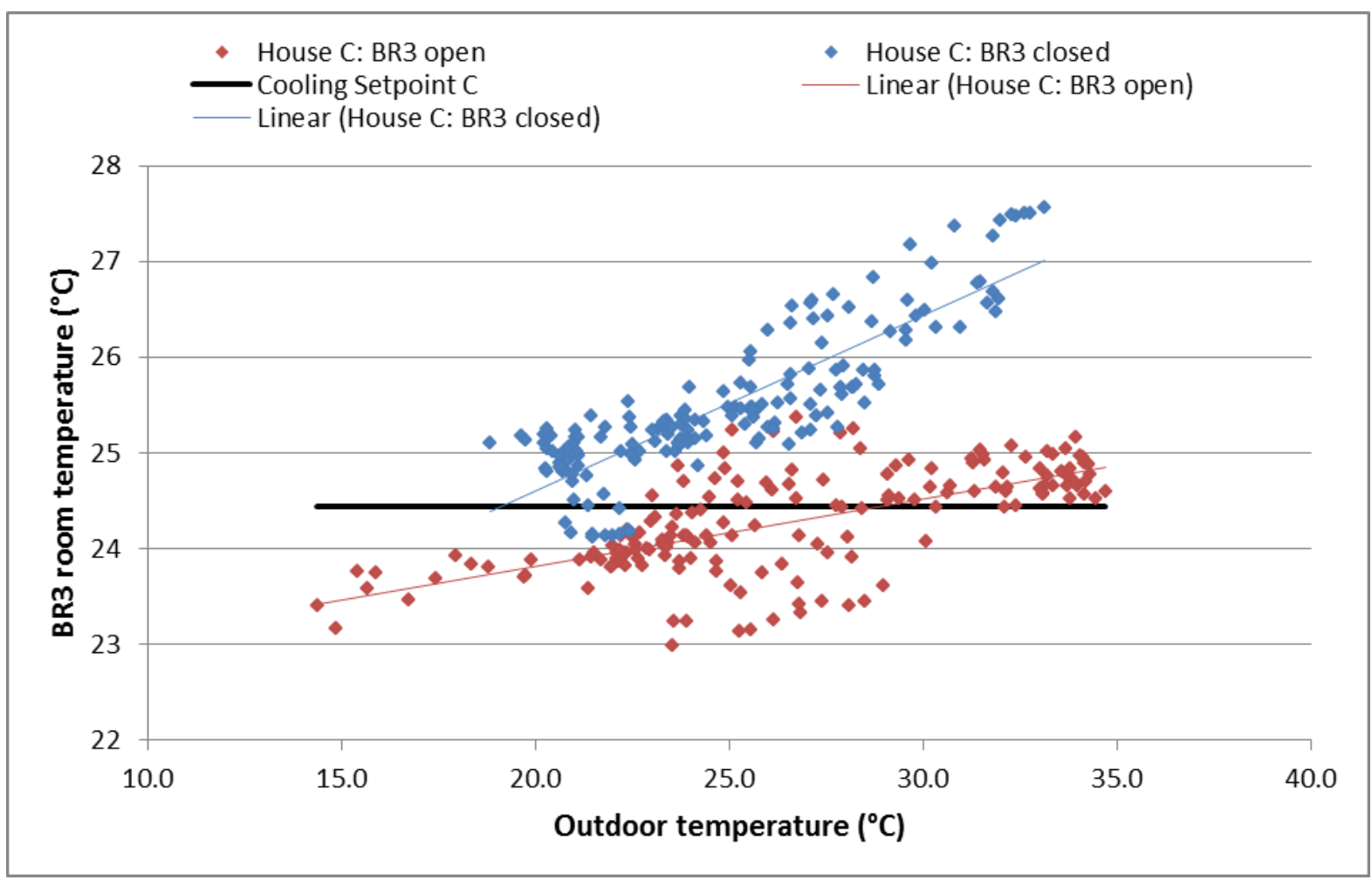

Figure 64. House $C$ impacts of door position on Bedroom 3 room temperature compared to outdoor temperature (cooling season) 


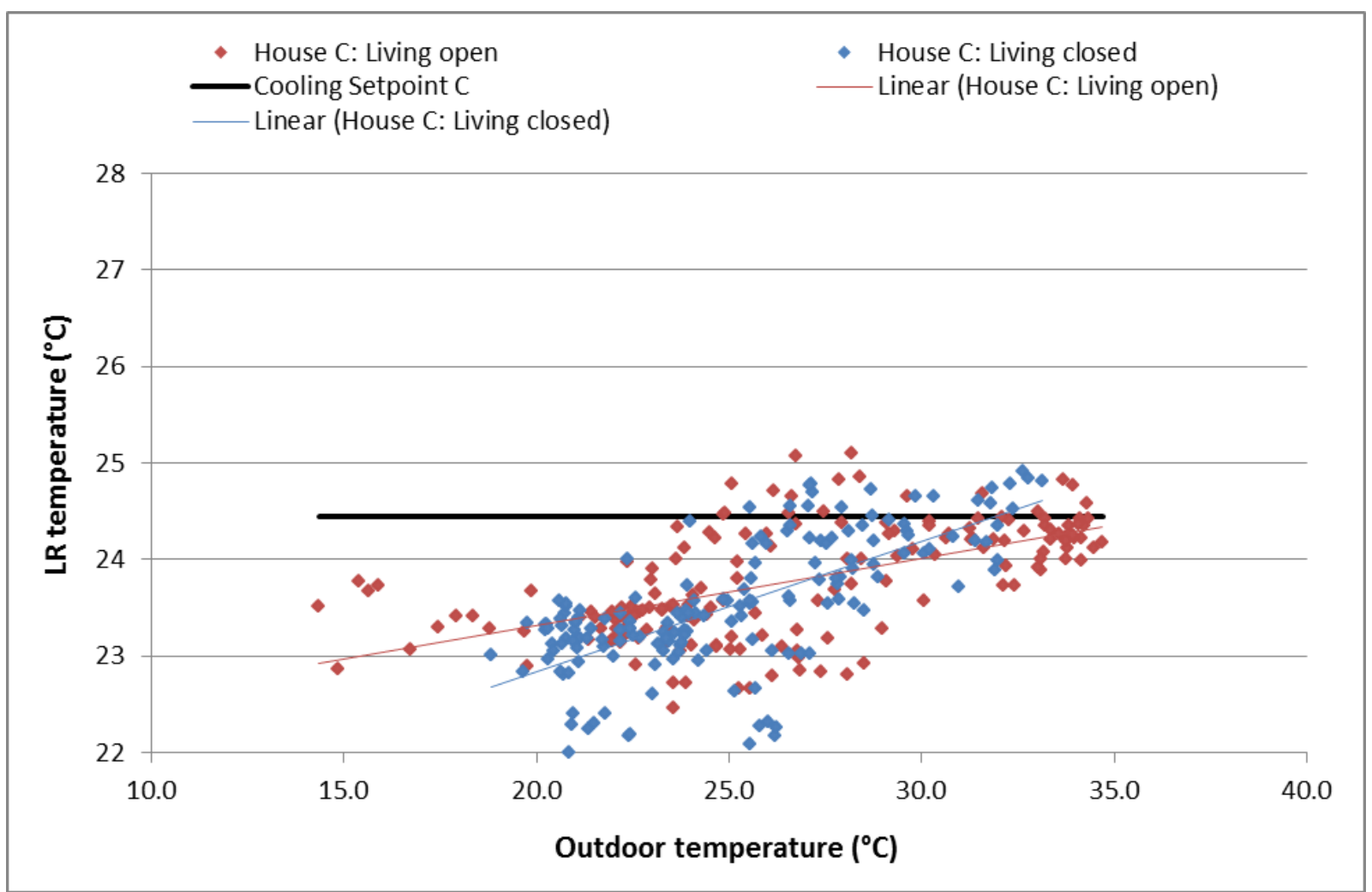

Figure 65. House C impacts of door position on living room temperature compared to outdoor temperature (cooling season) 


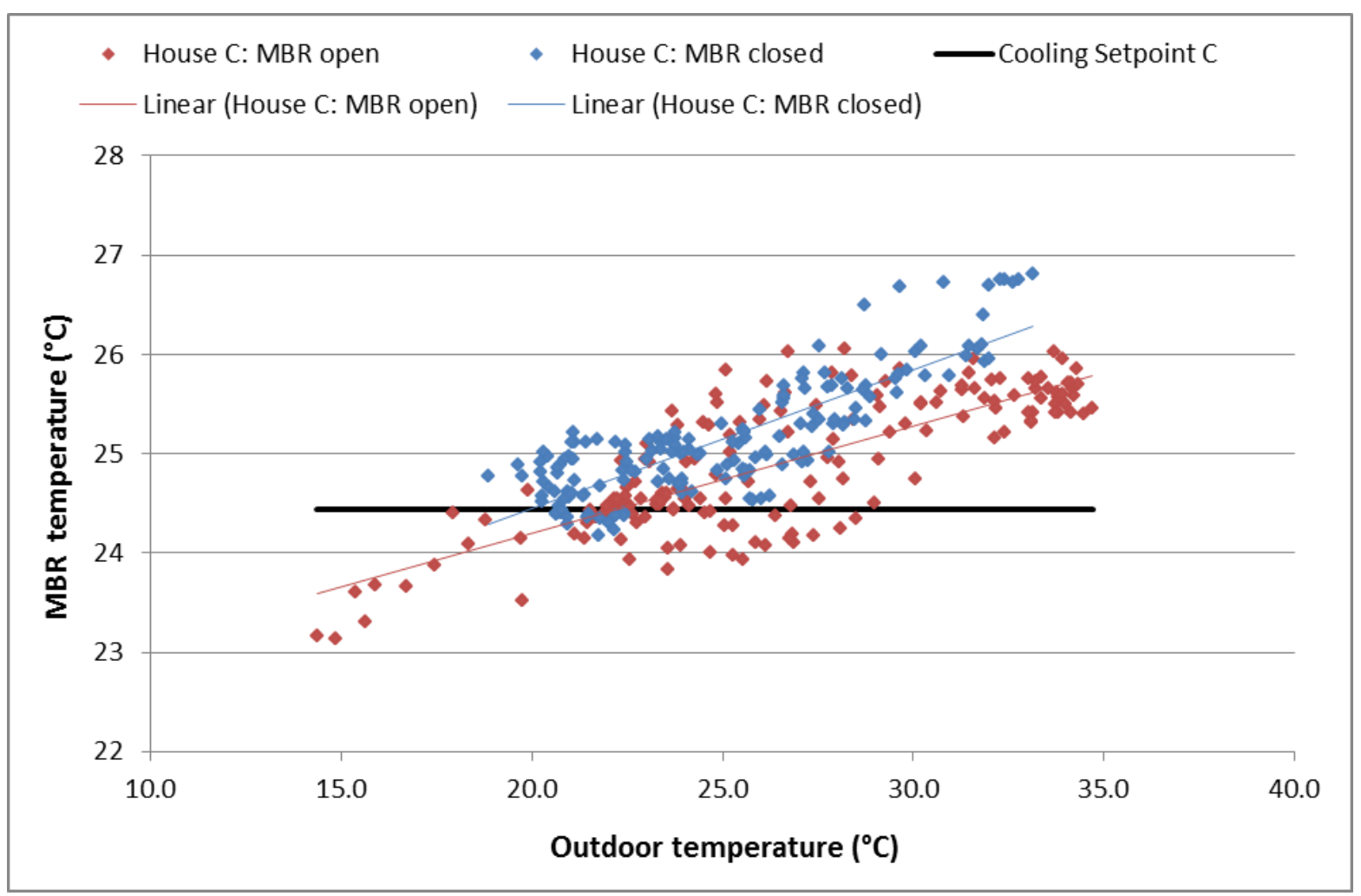

Figure 66. House C impacts of door position on master bedroom temperature compared to outdoor temperature (cooling season) 


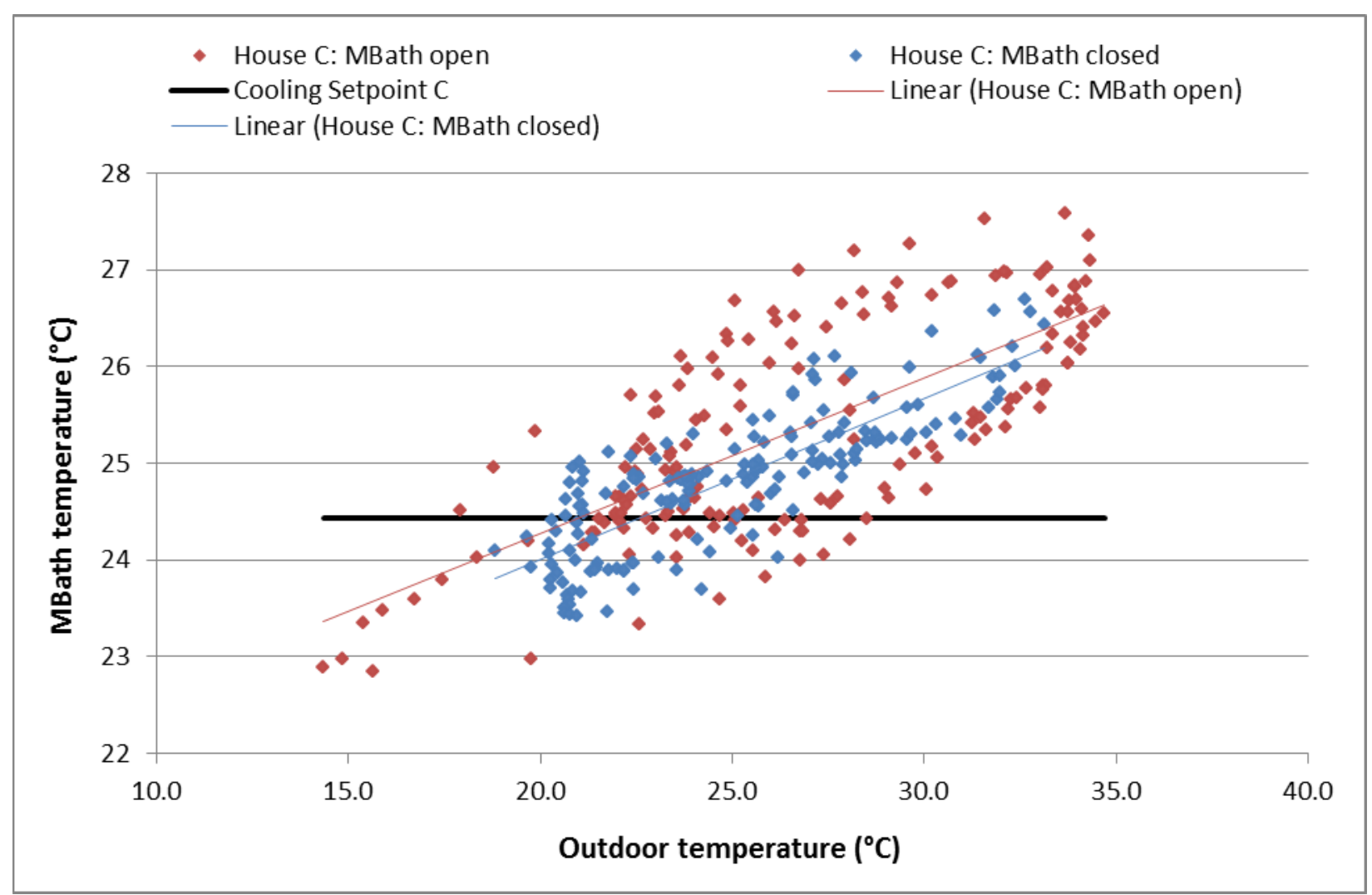

Figure 67. House $C$ impacts of door position on master bathroom temperature compared to outdoor temperature (cooling season) 


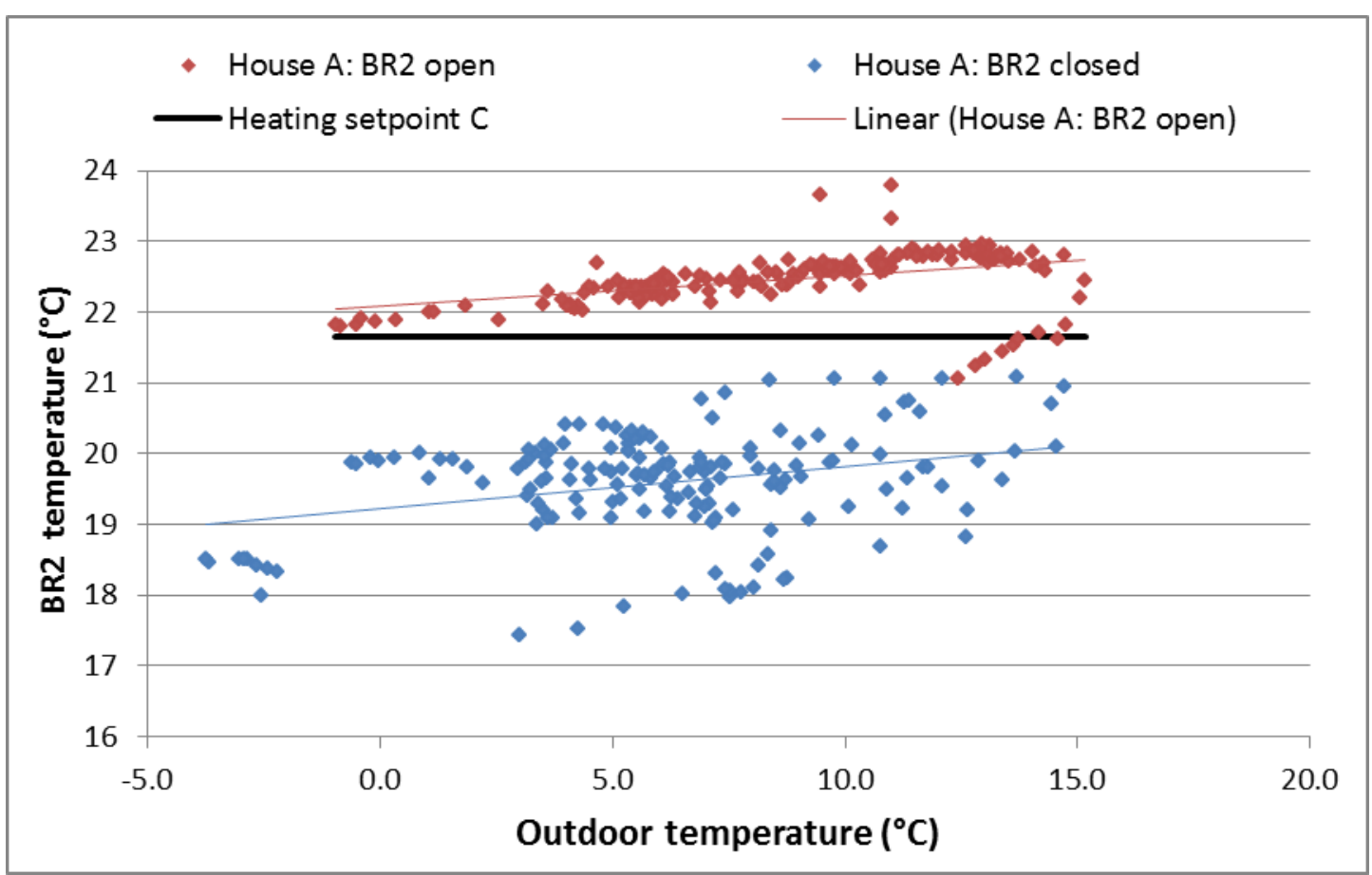

Figure 68. House A impacts of door position on Bedroom 2 temperature compared to outdoor temperature (heating season)

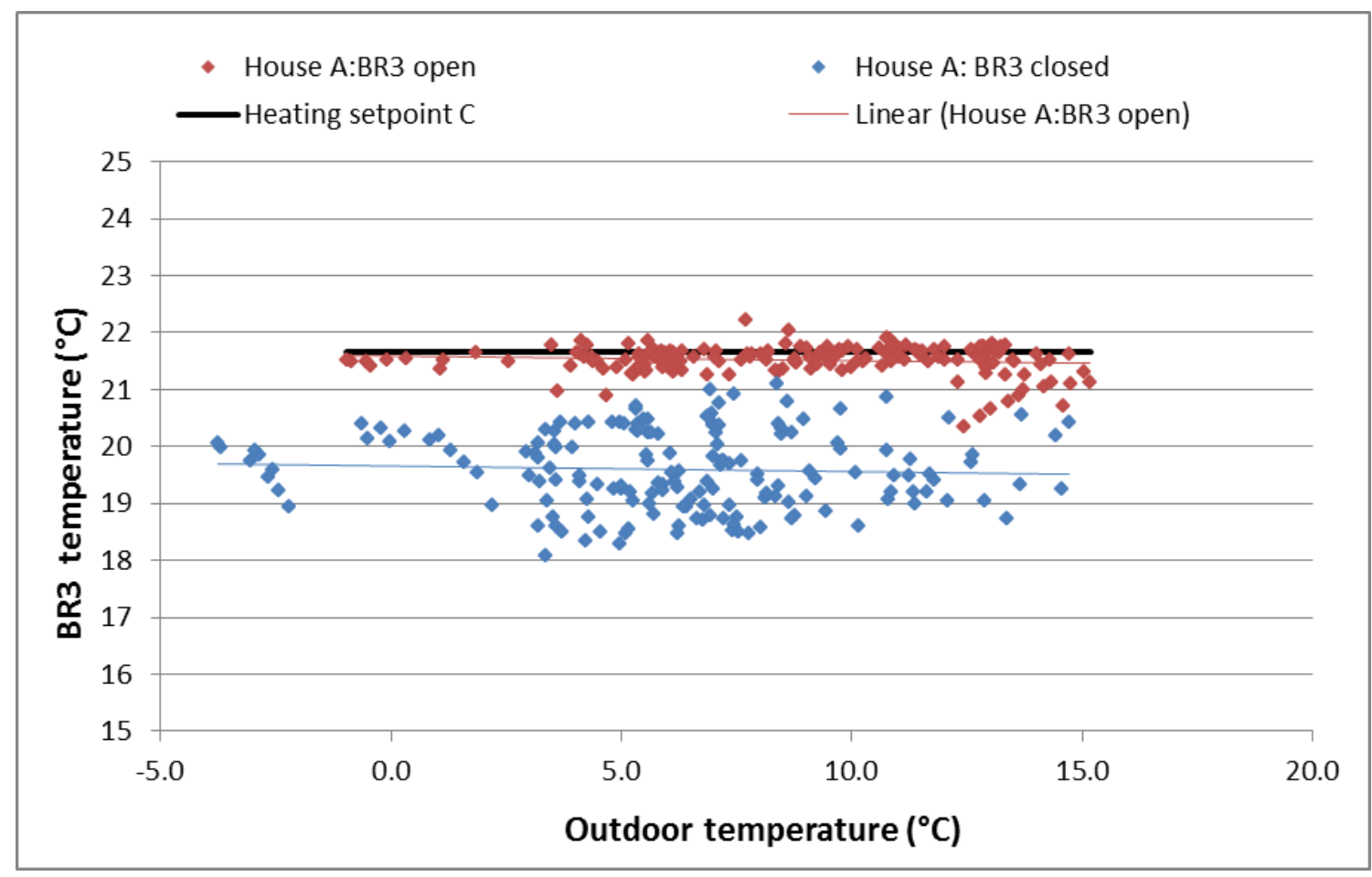

Figure 69. House A impacts of door position on Bedroom 3 temperature compared to outdoor temperature (heating season) 


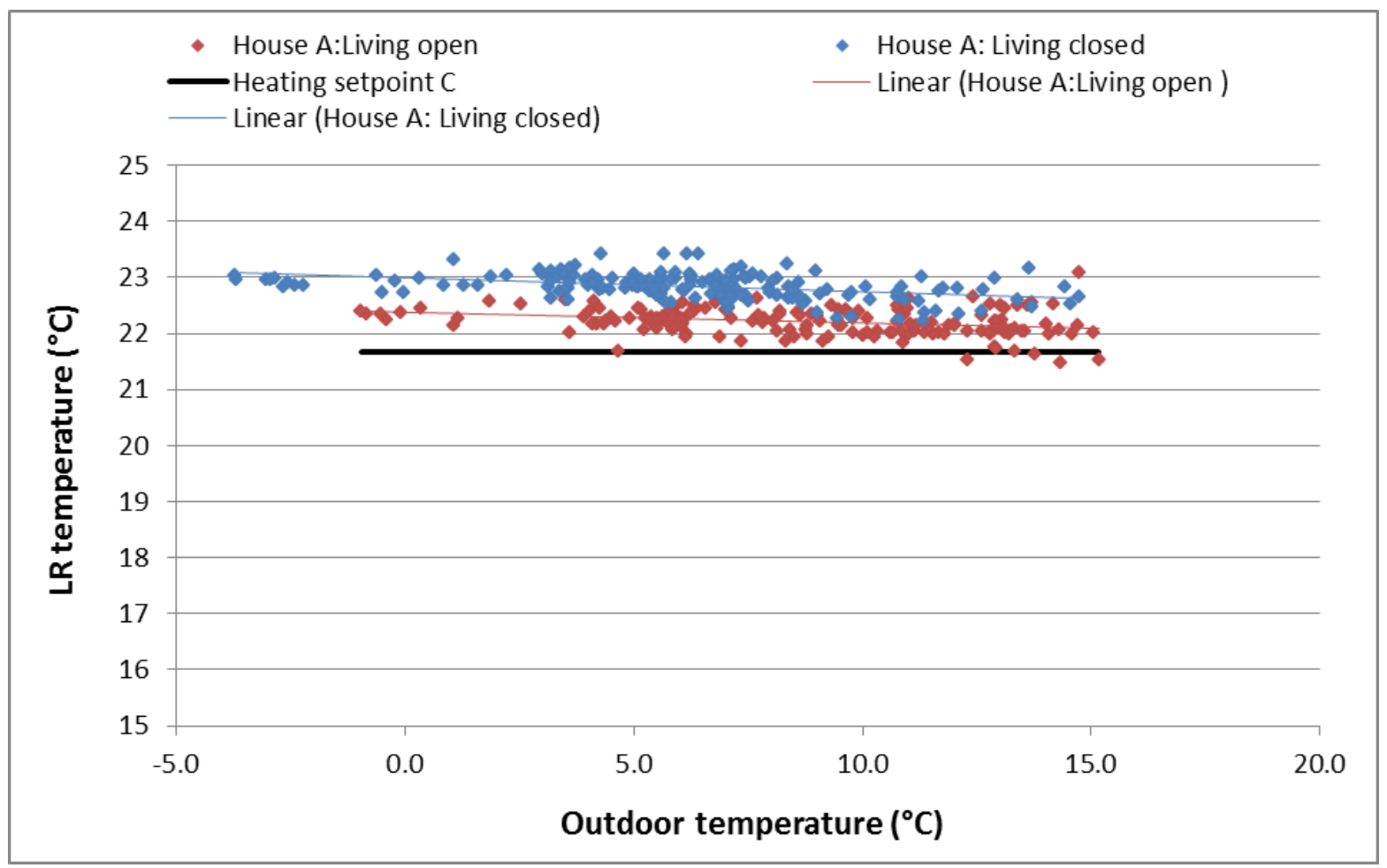

Figure 70. House A impacts of door position on living room temperature compared to outdoor temperature (heating season) 


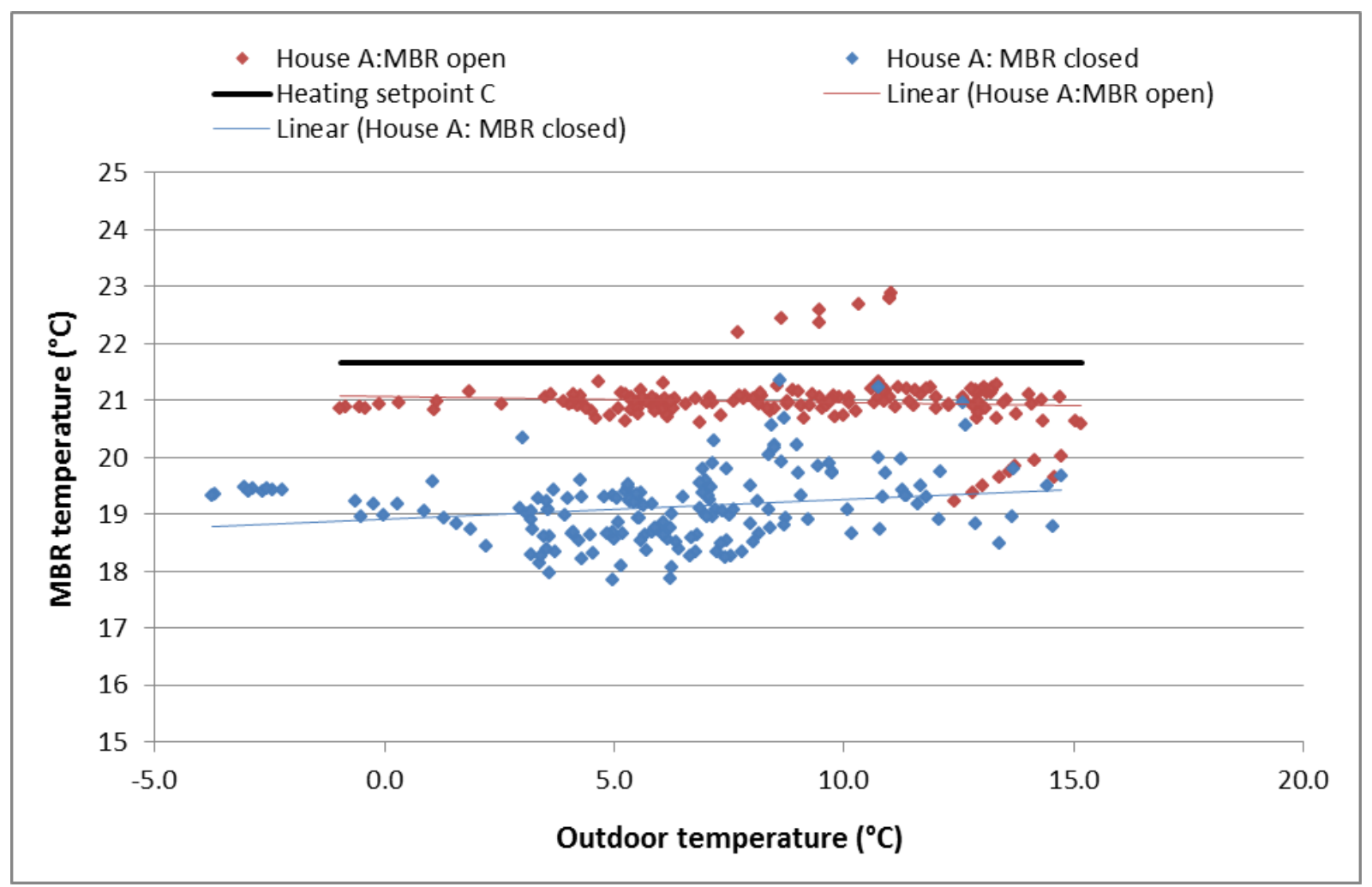

Figure 71. House A impacts of door position on master bedroom temperature compared to outdoor temperature (heating season) 


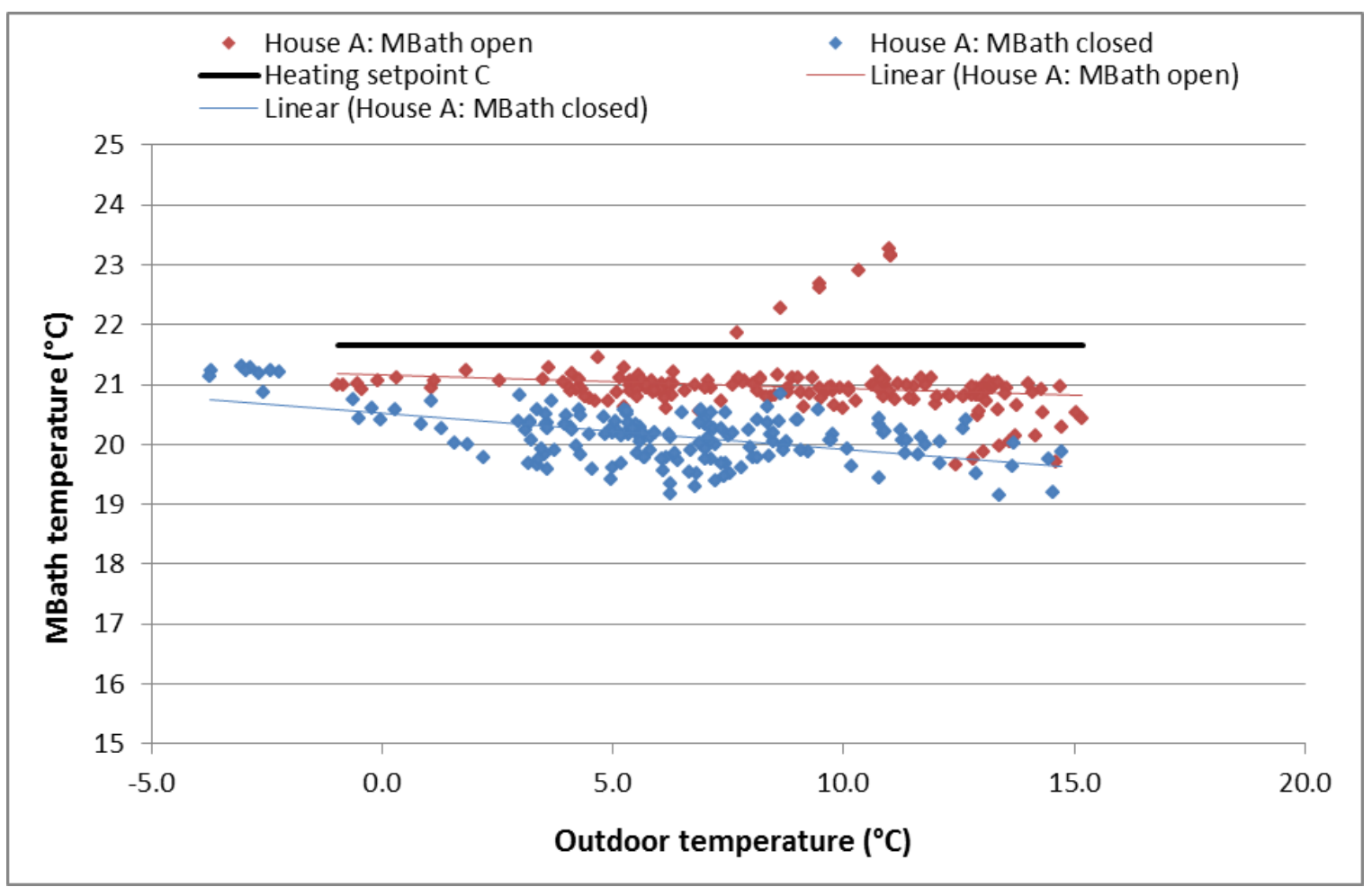

Figure 72. House A impacts of door position on master bathroom temperature compared to outdoor temperature (heating season) 


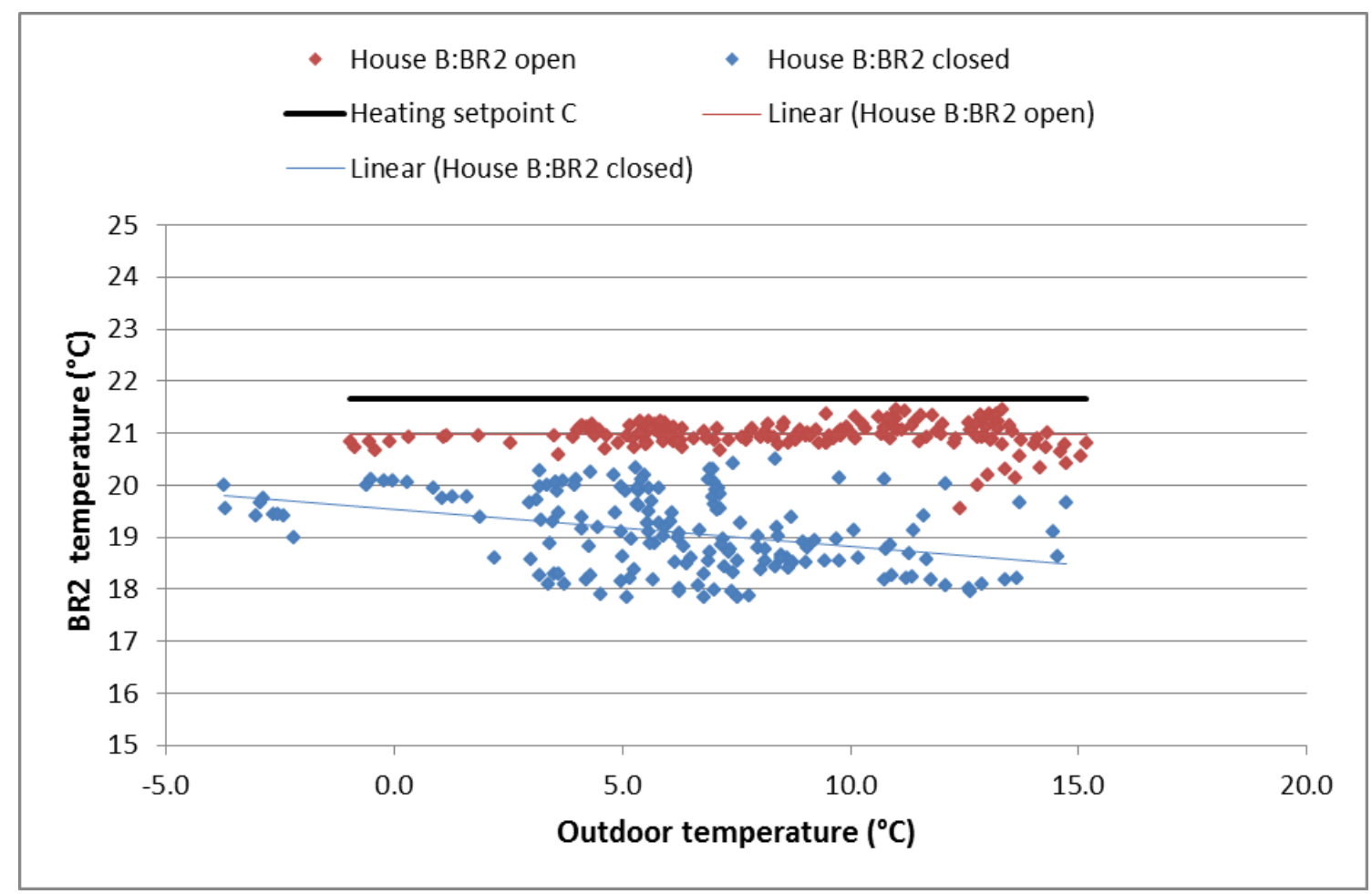

Figure 73. House B impacts of door position on Bedroom 2 temperature compared to outdoor temperature (heating season) 


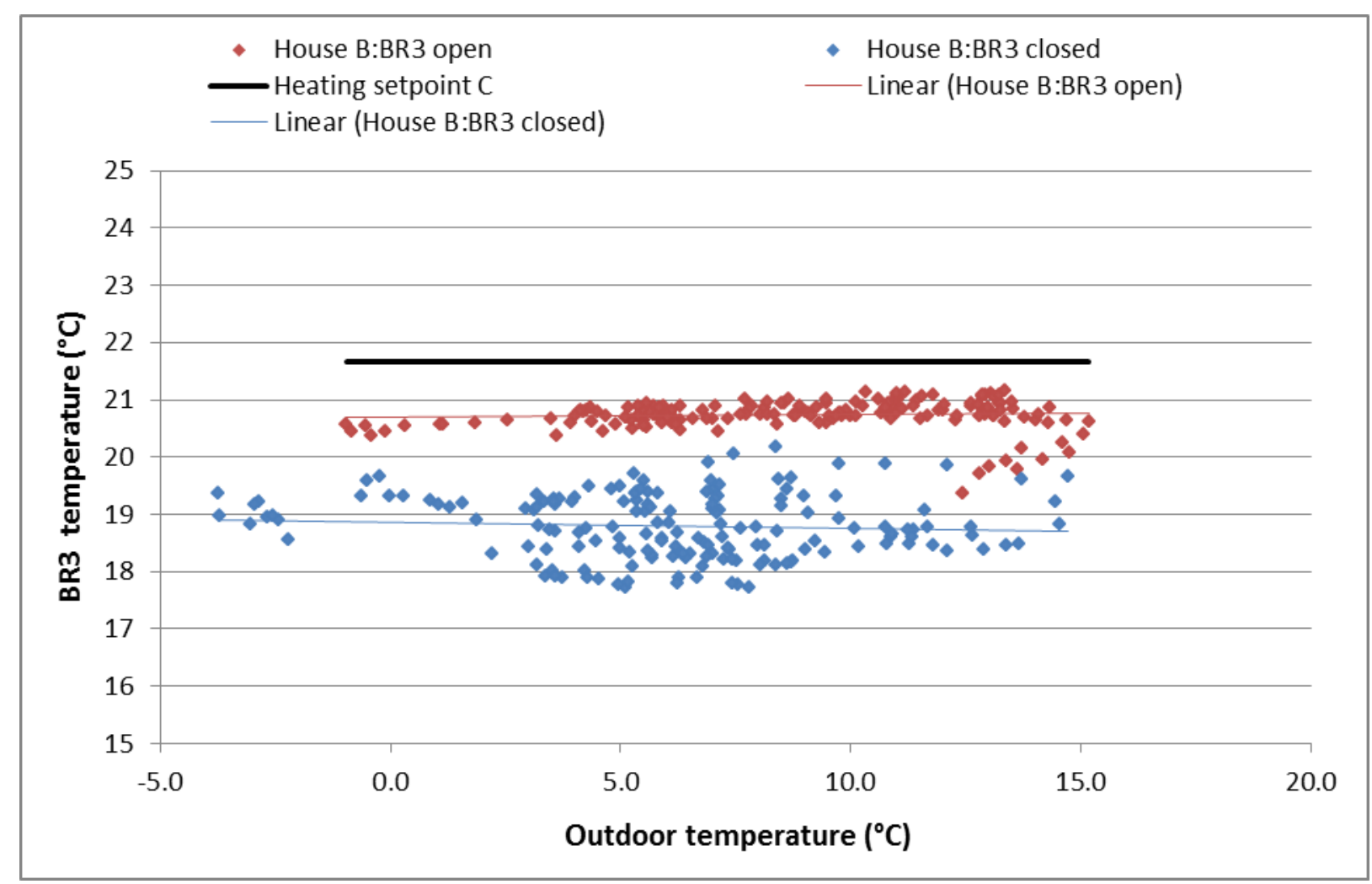

Figure 74. House B impacts of door position on Bedroom 3 temperature compared to outdoor temperature (heating season) 


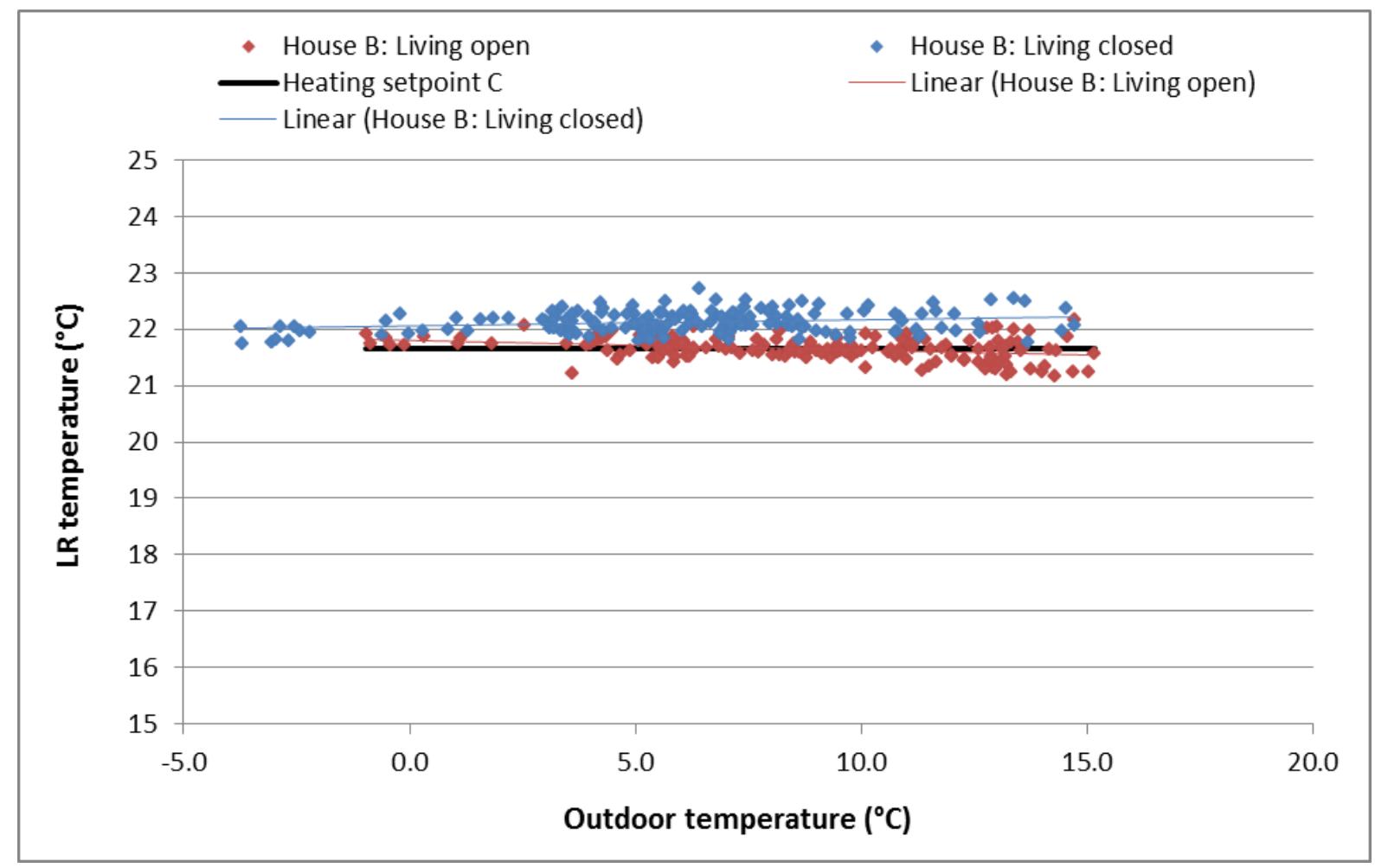

Figure 75. House B impacts of door position on living room temperature compared to outdoor temperature (heating season) 


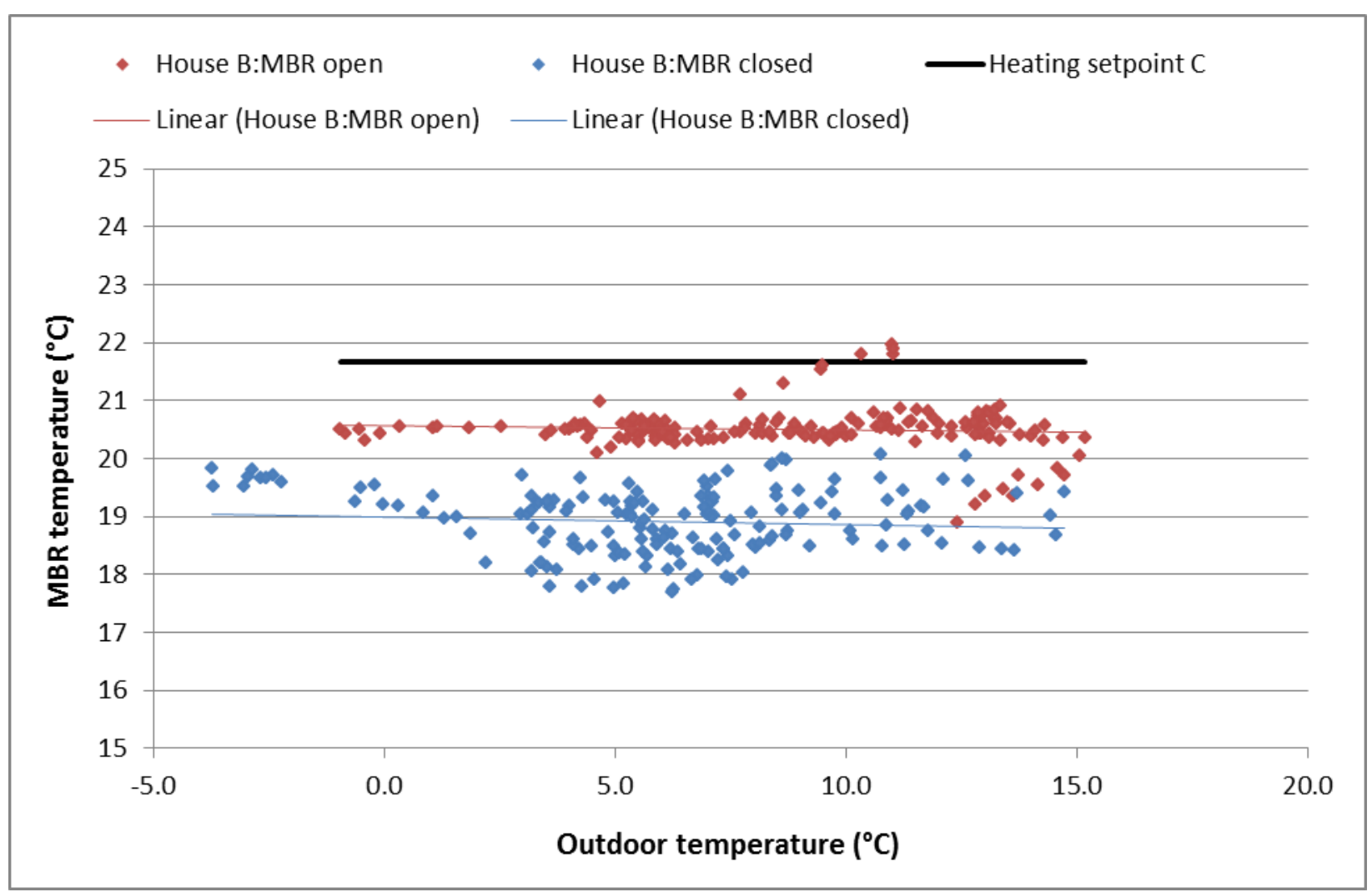

Figure 76. House B impacts of door position on master bedroom temperature compared to outdoor temperature (heating season) 


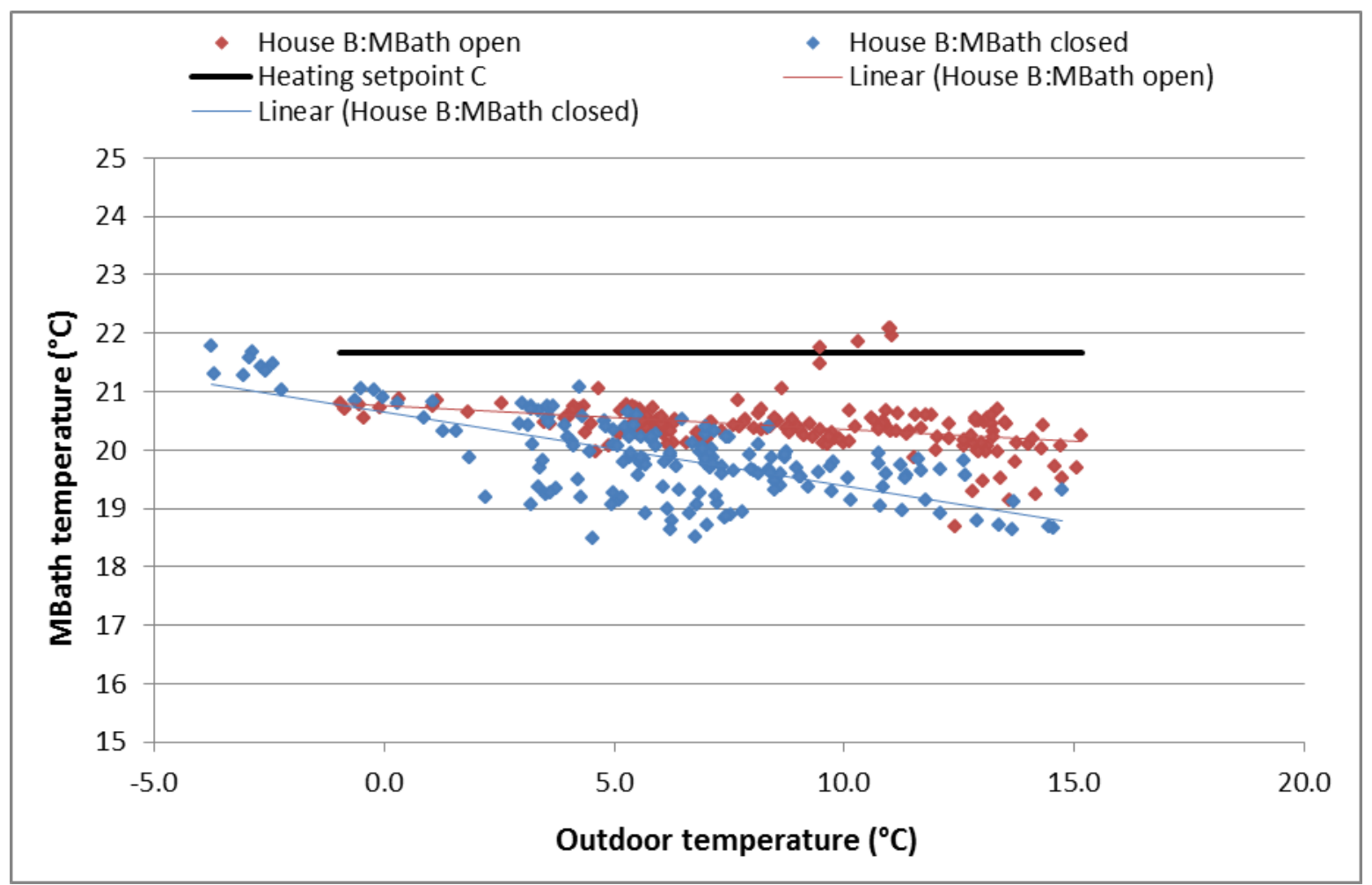

Figure 77. House B impacts of door position on master bathroom temperature compared to outdoor temperature (heating season) 


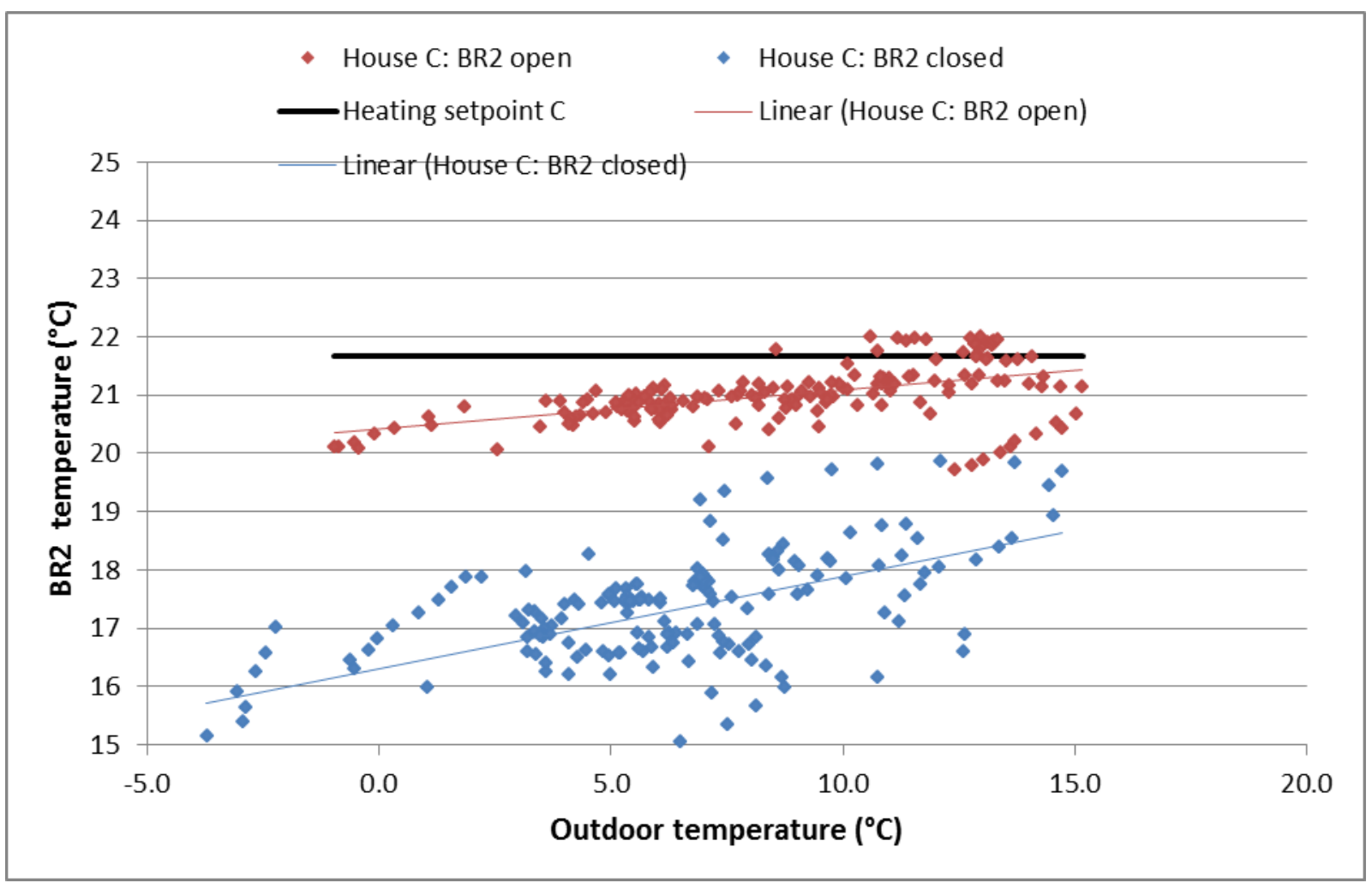

Figure 78. House $C$ impacts of door position on Bedroom 2 temperature compared to outdoor temperature (heating season) 


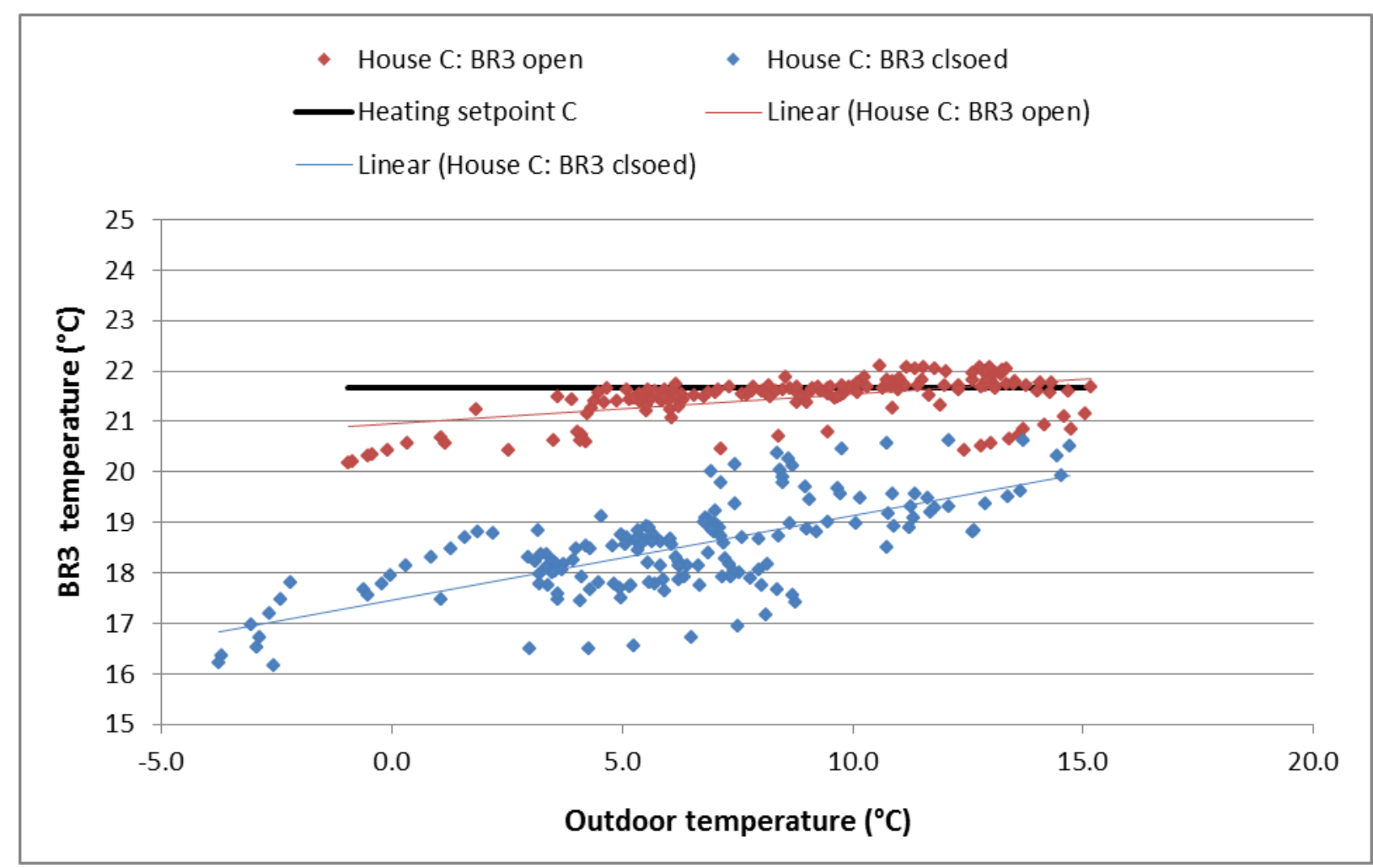

Figure 79. House $\mathrm{C}$ impacts of door position on Bedroom 3 temperature compared to outdoor temperature (heating season) 


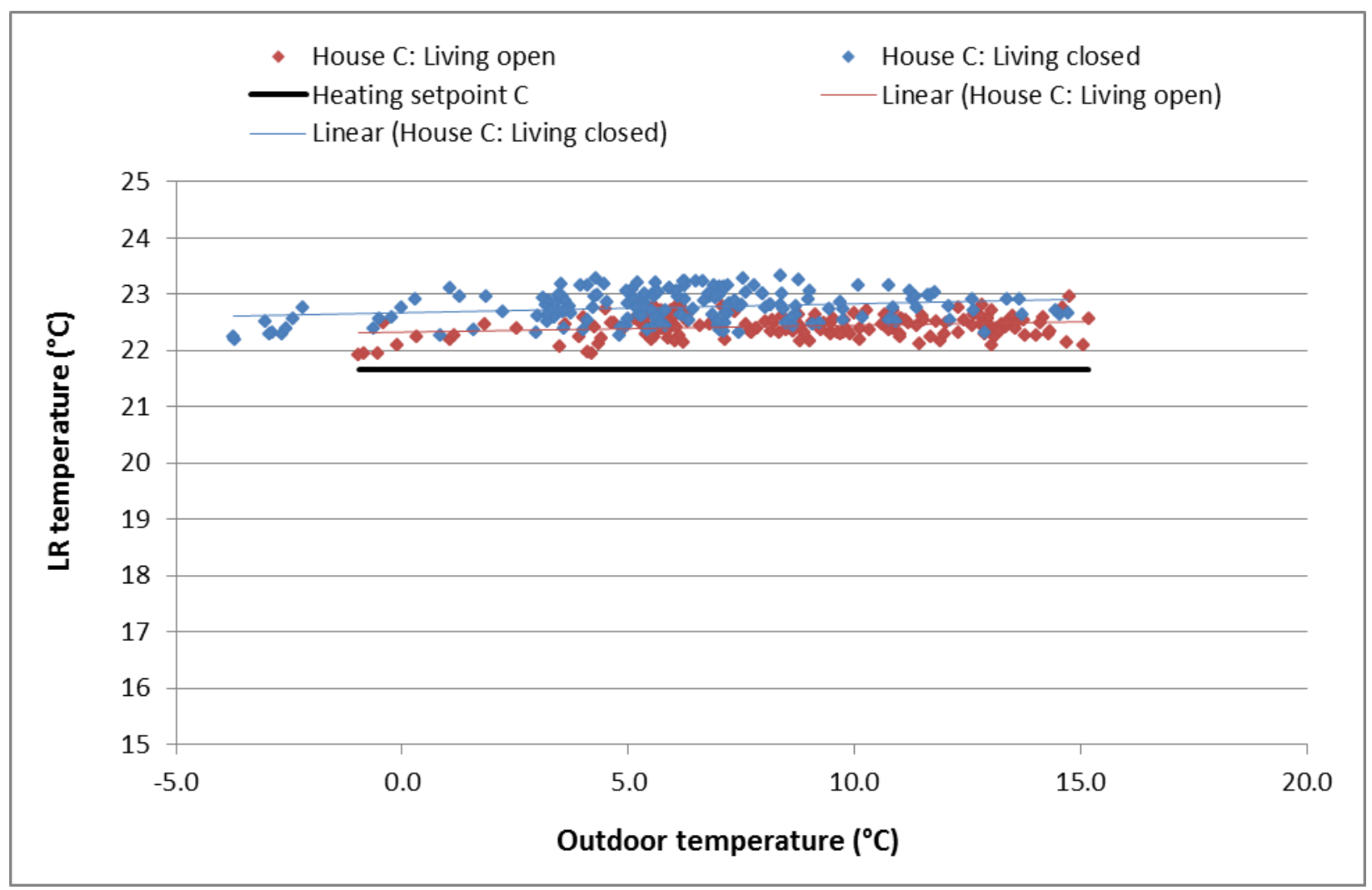

Figure 80. House C impacts of door position on living room temperature compared to outdoor temperature (heating season) 


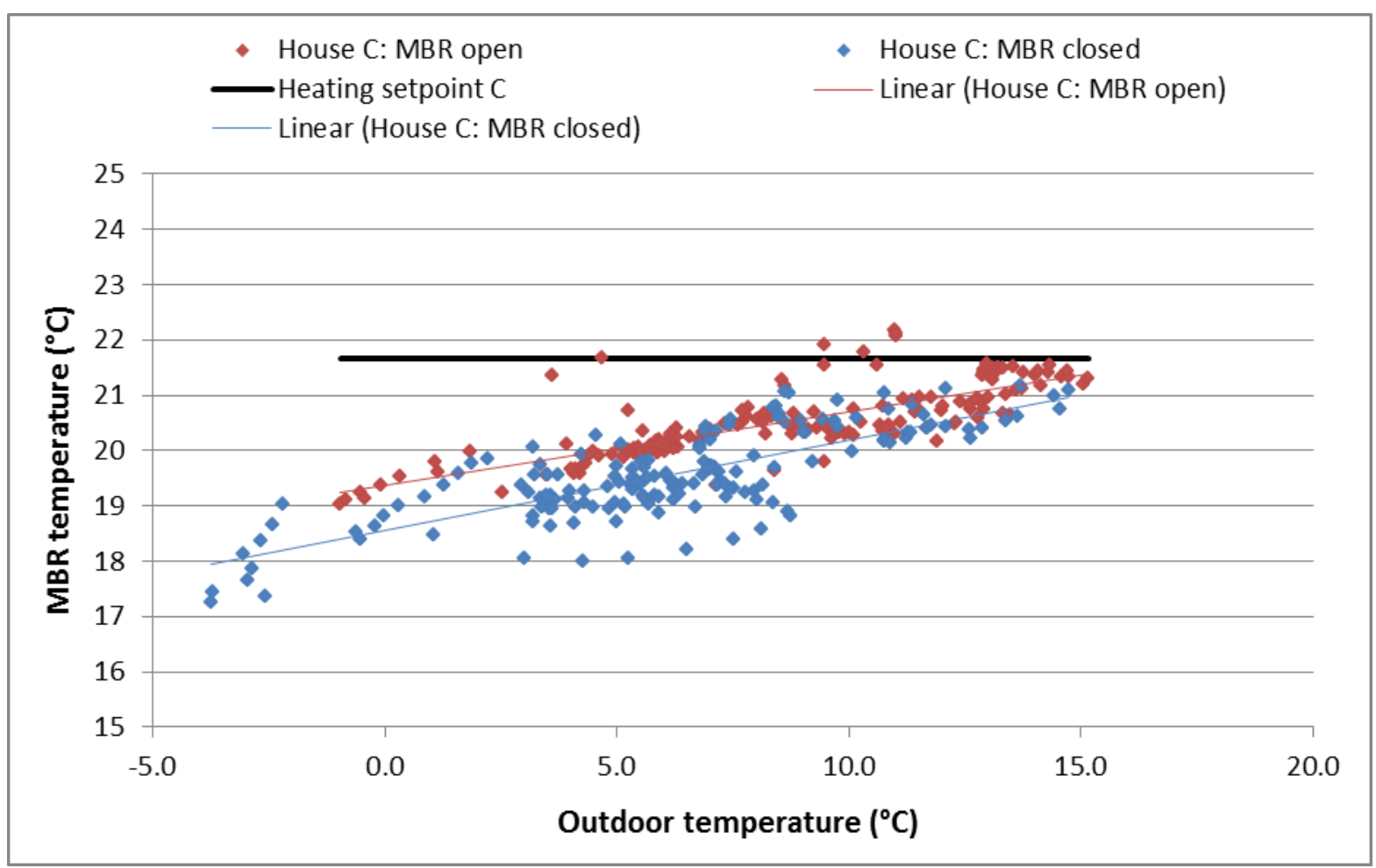

Figure 81. House C impacts of door position on master bedroom temperature compared to outdoor temperature (heating season) 


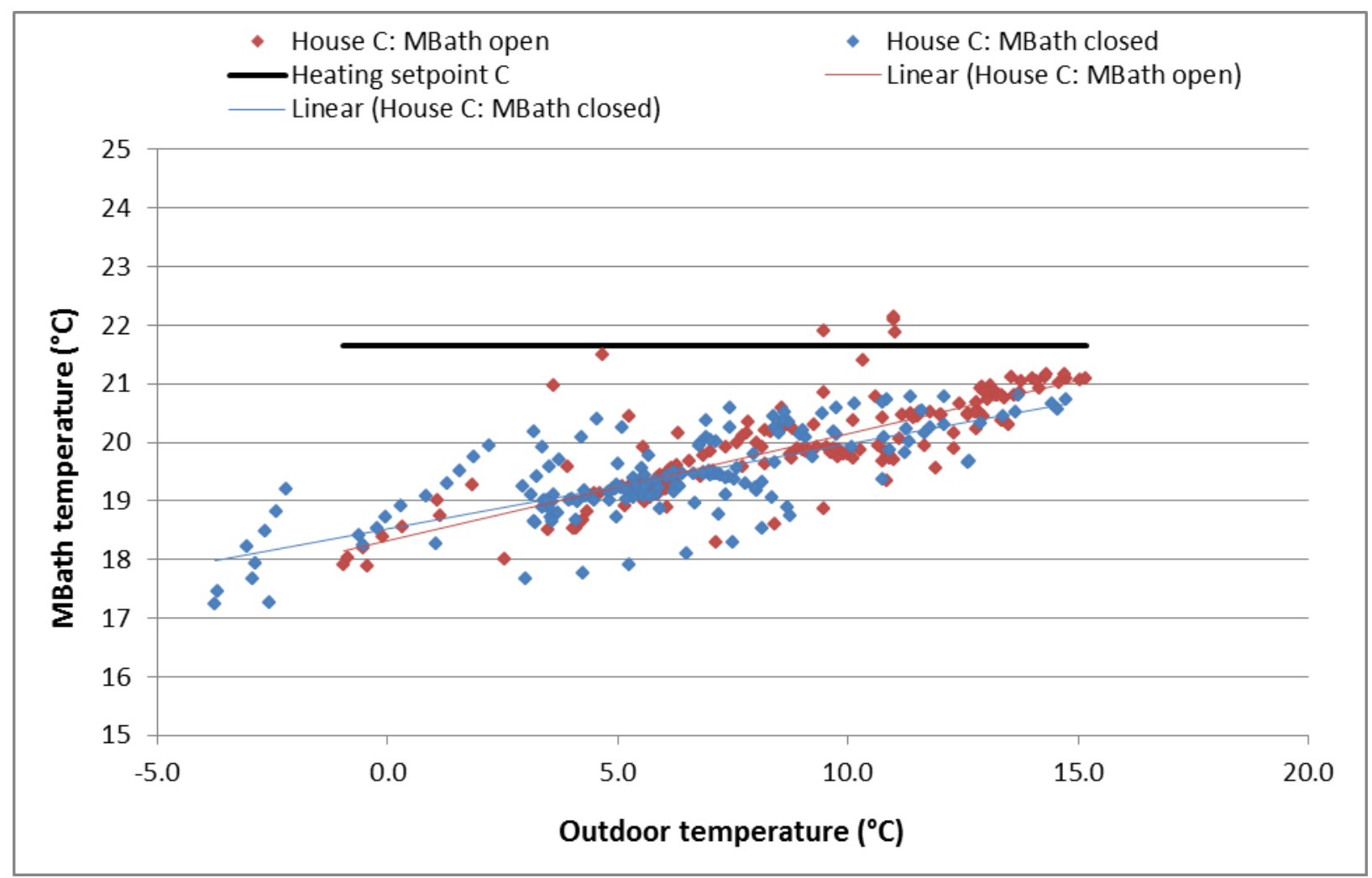

Figure 82. House $\mathrm{C}$ impacts of door position on master bathroom temperature compared to outdoor temperature (heating season) 


\section{Appendix F: Tracer Gas Test Data}

Table 50. Tracer Gas Test Data

\begin{tabular}{|c|c|c|c|c|c|c|c|c|}
\hline \multirow[b]{2}{*}{2014} & \multirow[b]{2}{*}{ Hour } & \multirow[b]{2}{*}{ ppm } & House C & \multicolumn{2}{|c|}{ House B } & \multicolumn{2}{|c|}{ House A } & \multirow[t]{2}{*}{ Notes } \\
\hline & & & $\mathrm{ACH}$ & $\mathrm{ppm}$ & $\mathrm{ACH}$ & $\mathrm{ppm}$ & $\mathrm{ACH}$ & \\
\hline \multirow[t]{8}{*}{ Dec. 8} & 17 & 3.01 & & 3.06 & & & & $\begin{array}{l}\text { Normal operation of } \\
\text { HVAC in all three houses. } \\
\text { House } C \text { exhaust fan off }\end{array}$ \\
\hline & 18 & 2.62 & 0.14 & 2.51 & 0.20 & & & \\
\hline & 19 & 2.31 & 0.13 & 2.07 & 0.19 & & & \\
\hline & 20 & 2.03 & 0.13 & 1.64 & 0.23 & & & \\
\hline & 21 & 1.81 & 0.11 & 1.34 & 0.20 & & & \\
\hline & 22 & 1.61 & 0.12 & 1.1 & 0.20 & & & \\
\hline & 23 & 1.43 & 0.12 & 0.867 & 0.24 & & & \\
\hline & 0 & 1.27 & 0.12 & 0.696 & 0.22 & & & \\
\hline \multirow[t]{16}{*}{ Dec. 9} & 1 & 1.11 & 0.13 & 0.553 & 0.23 & & & \\
\hline & 2 & 0.972 & 0.13 & 0.443 & 0.22 & & & \\
\hline & 3 & 0.851 & 0.13 & 0.339 & 0.27 & & & \\
\hline & 4 & 0.743 & 0.14 & 0.273 & 0.22 & & & \\
\hline & 5 & 0.655 & 0.13 & 0.214 & 0.24 & & & \\
\hline & 6 & 0.573 & 0.13 & 0.171 & 0.22 & & & \\
\hline & 7 & 0.493 & 0.15 & 0.145 & 0.16 & & & \\
\hline & 8 & 0.409 & 0.19 & & & & & $\begin{array}{l}\text { House } C \text { exhaust fan on } \\
\text { starting at } 7: 30 \text { a.m. }\end{array}$ \\
\hline & 9 & 0.307 & 0.29 & & & & & House $\mathrm{C}$ exhaust fan on \\
\hline & 10 & 0.235 & 0.27 & & & & & House $\mathrm{C}$ exhaust fan on \\
\hline & 11 & & & & & & & $\begin{array}{l}\text { House } C \text { exhaust fan off } \\
\text { until Dec } 11\end{array}$ \\
\hline & 12 & & & & & & & \\
\hline & 13 & & & & & & & \\
\hline & 14 & & & & & & & \\
\hline & 15 & & & & & & & \\
\hline & 16 & & & & & & & \\
\hline
\end{tabular}




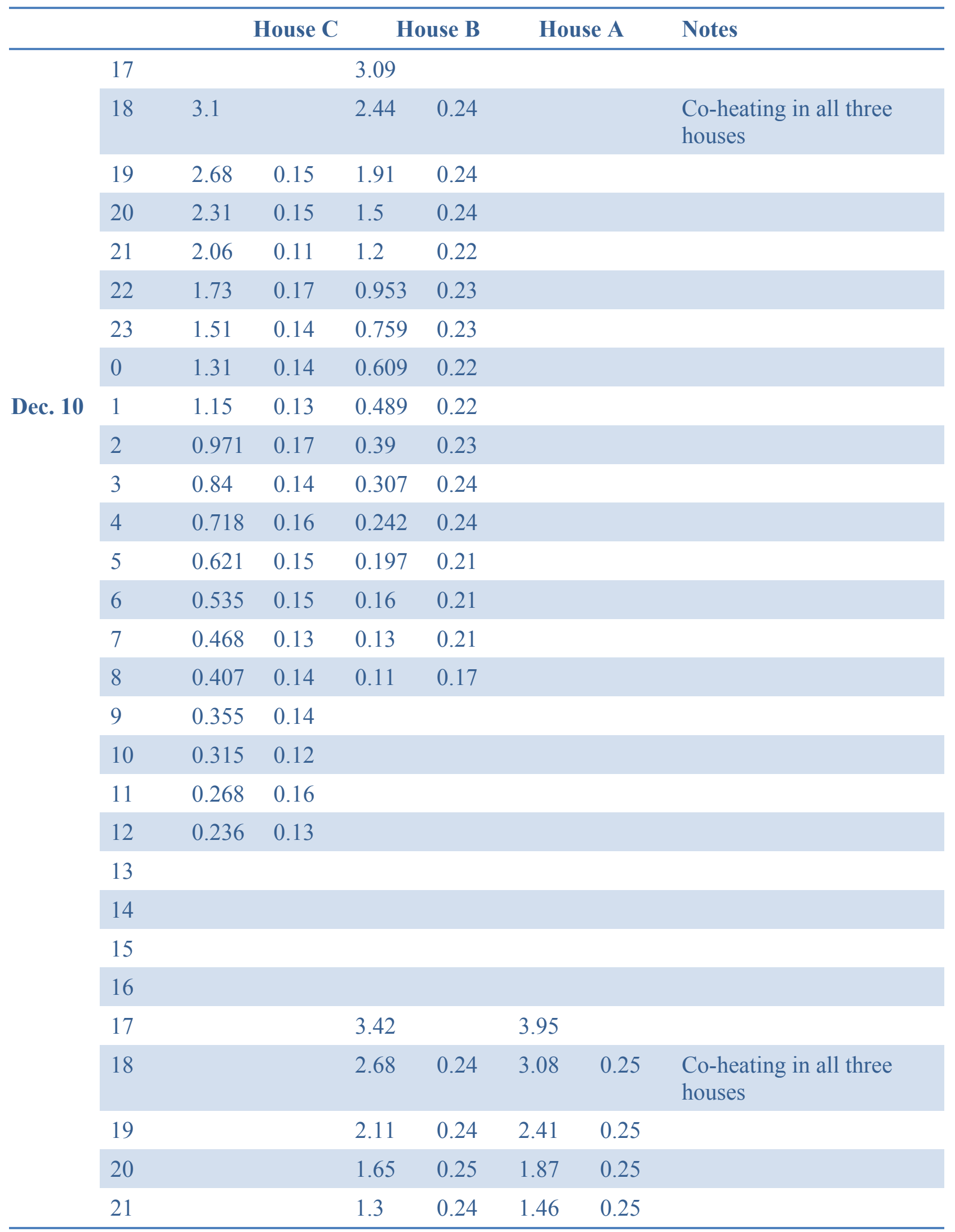




\begin{tabular}{|c|c|c|c|c|c|c|}
\hline & & House C & use $B$ & Hou & e A & Notes \\
\hline & 22 & 1.01 & 0.25 & 1.12 & 0.27 & \\
\hline & 23 & 0.784 & 0.25 & 0.872 & 0.25 & \\
\hline & 0 & 0.607 & 0.26 & 0.675 & 0.26 & \\
\hline Dec. 11 & 1 & 0.477 & 0.24 & 0.525 & 0.25 & \\
\hline & 2 & 0.371 & 0.25 & 0.408 & 0.25 & \\
\hline & 3 & 0.292 & 0.24 & 0.321 & 0.24 & \\
\hline & 4 & 0.23 & 0.24 & 0.252 & 0.24 & \\
\hline & 5 & 0.183 & 0.23 & 0.199 & 0.24 & \\
\hline & 6 & 0.147 & 0.22 & 0.151 & 0.28 & \\
\hline & 7 & 0.117 & 0.23 & 0.121 & 0.22 & \\
\hline & 8 & & & & & \\
\hline & 9 & & & & & \\
\hline & 10 & & & & & \\
\hline & 11 & & & & & \\
\hline & 12 & & & & & \\
\hline & 13 & & & & & \\
\hline & 14 & & & & & \\
\hline & 15 & & & & & \\
\hline & 16 & & & & & \\
\hline & 17 & & & & & $\begin{array}{l}\text { Normal operation of } \\
\text { HVAC in all three houses. } \\
\text { House C exhaust fan on }\end{array}$ \\
\hline & 18 & 3.21 & & 2.82 & & \\
\hline & 19 & 2.51 & 0.25 & 2.23 & 0.23 & \\
\hline & 20 & 1.85 & 0.31 & 1.75 & 0.24 & \\
\hline & 21 & 1.43 & 0.26 & 1.34 & 0.27 & \\
\hline & 22 & 1.15 & 0.22 & 1.06 & 0.23 & \\
\hline & 23 & 0.859 & 0.29 & 0.815 & 0.26 & \\
\hline & 0 & 0.658 & 0.27 & 0.637 & 0.25 & \\
\hline Dec. 12 & 1 & 0.504 & 0.27 & 0.502 & 0.24 & \\
\hline & 2 & 0.384 & 0.27 & 0.392 & 0.25 & \\
\hline
\end{tabular}


\begin{tabular}{l|l} 
u.s. Department of & Energy Efficiency \& \\
Renewable Energy
\end{tabular}

\begin{tabular}{lllllll}
\hline & House C & House B & \multicolumn{2}{c}{ House A } & Notes \\
\hline 3 & 0.299 & 0.25 & 0.299 & 0.27 & \\
4 & 0.233 & 0.25 & 0.236 & 0.24 & \\
5 & 0.159 & 0.38 & 0.182 & 0.26 \\
6 & 0.126 & 0.23 & 0.148 & 0.21 \\
7 & 0.109 & & & \\
\hline
\end{tabular}




\section{Appendix G: Co-Heat Testing Data}

Table 51. House A Co-Heat Testing Data

\begin{tabular}{|c|c|c|c|c|c|c|c|c|c|}
\hline $\begin{array}{c}\text { Time } \\
\text { Stamp }\end{array}$ & $\begin{array}{c}\text { Outdoor } \\
\text { Temp. }\end{array}$ & $\begin{array}{l}\text { Avg. } \\
\text { Indoor } \\
\text { Temp. }\end{array}$ & $\begin{array}{c}\text { Sensible } \\
\text { Gain } \\
\text { Heater }\end{array}$ & $\begin{array}{c}\text { Sensible } \\
\text { Gain } \\
\text { Heater }\end{array}$ & $\begin{array}{l}\text { Main } \\
\text { Panel }\end{array}$ & $\begin{array}{c}\text { Outdoor } \\
\text { Unit }\end{array}$ & $\begin{array}{l}\text { Air } \\
\text { Hand- } \\
\text { ling } \\
\text { Unit } \\
\text { Fan }\end{array}$ & $\begin{array}{c}\text { Total } \\
\text { Internal } \\
\text { Gain }\end{array}$ & $\begin{array}{l}\text { Calculated } \\
\text { Simple UA }\end{array}$ \\
\hline & $\left({ }^{\circ} \mathrm{C}\right)$ & $\left({ }^{\circ} \mathrm{C}\right)$ & $(\mathrm{kW})$ & $(\mathrm{kW})$ & $(\mathrm{kW})$ & $(\mathrm{kW})$ & $(\mathrm{kW})$ & $(\mathrm{kW})$ & $\left(\mathrm{kW} /{ }^{\circ} \mathrm{C}\right)$ \\
\hline $12 / 10 / 20142: 00$ & 3.1 & 23.0 & 0.304 & 0.197 & 3.467 & 0.011 & 0.001 & 3.467 & 0.174 \\
\hline $12 / 10 / 20143: 00$ & 3.2 & 23.0 & 0.297 & 0.197 & 3.435 & 0.011 & 0.002 & 3.435 & 0.174 \\
\hline $12 / 10 / 20144: 00$ & 3.2 & 23.0 & 0.283 & 0.197 & 3.417 & 0.011 & 0.002 & 3.417 & 0.172 \\
\hline 12/10/2014 5:00 & 3.2 & 23.0 & 0.281 & 0.201 & 3.405 & 0.011 & 0.001 & 3.405 & 0.172 \\
\hline $12 / 10 / 20146: 00$ & 3.3 & 23.0 & 0.300 & 0.209 & 3.268 & 0.011 & 0.001 & 3.268 & 0.166 \\
\hline 12/11/2014 2:00 & -1.7 & 23.0 & 0.001 & 0.002 & 3.933 & 0.000 & 0.001 & 3.933 & 0.159 \\
\hline 12/11/2014 3:00 & -1.3 & 23.0 & 0.001 & 0.002 & 3.934 & 0.000 & 0.001 & 3.934 & 0.162 \\
\hline $12 / 11 / 20144: 00$ & -1.9 & 23.0 & 0.001 & 0.002 & 3.936 & 0.000 & 0.001 & 3.936 & 0.158 \\
\hline $12 / 11 / 20145: 00$ & -2.8 & 23.0 & 0.001 & 0.002 & 4.043 & 0.000 & 0.001 & 4.043 & 0.156 \\
\hline 12/11/2014 6:00 & -3.1 & 23.0 & 0.001 & 0.002 & 4.037 & 0.000 & 0.001 & 4.037 & 0.154 \\
\hline
\end{tabular}


Table 52. House B Co-Heat Testing Data

\begin{tabular}{|c|c|c|c|c|c|c|c|c|c|}
\hline $\begin{array}{c}\text { Time } \\
\text { Stamp }\end{array}$ & $\begin{array}{c}\text { Outdoor } \\
\text { Temp. }\end{array}$ & $\begin{array}{c}\text { Avg. } \\
\text { Indoor } \\
\text { Temp. }\end{array}$ & $\begin{array}{c}\text { Sensible } \\
\text { Gain } \\
\text { Heater }\end{array}$ & $\begin{array}{c}\text { Sensible } \\
\text { Gain } \\
\text { Heater }\end{array}$ & $\begin{array}{l}\text { Main } \\
\text { Panel }\end{array}$ & $\begin{array}{l}\text { Outdoor } \\
\text { Unit }\end{array}$ & $\begin{array}{c}\text { Air } \\
\text { Hand- } \\
\text { ling Unit } \\
\text { Fan }\end{array}$ & $\begin{array}{c}\text { Total } \\
\text { Internal } \\
\text { Gain }\end{array}$ & $\begin{array}{l}\text { Calculated } \\
\text { Simple UA }\end{array}$ \\
\hline & $\left({ }^{\circ} \mathrm{C}\right)$ & $\left({ }^{\circ} \mathrm{C}\right)$ & $(\mathrm{kW})$ & $(\mathrm{kW})$ & $(\mathrm{kW})$ & $(\mathrm{kW})$ & $(\mathrm{kW})$ & $(\mathrm{kW})$ & $\left(\mathrm{kW} /{ }^{\circ} \mathrm{C}\right)$ \\
\hline $12 / 10 / 20142: 00$ & 3.1 & 23.0 & 0.301 & 0.197 & 2.617 & 0.006 & 0.008 & 2.617 & 0.132 \\
\hline $12 / 10 / 20143: 00$ & 3.2 & 23.0 & 0.292 & 0.197 & 2.680 & 0.006 & 0.008 & 2.680 & 0.135 \\
\hline $12 / 10 / 20144: 00$ & 3.2 & 23.0 & 0.281 & 0.196 & 2.603 & 0.006 & 0.008 & 2.603 & 0.132 \\
\hline 12/10/2014 5:00 & 3.2 & 23.0 & 0.279 & 0.199 & 2.603 & 0.006 & 0.008 & 2.603 & 0.132 \\
\hline $12 / 10 / 20146: 00$ & 3.3 & 23.0 & 0.298 & 0.208 & 2.562 & 0.006 & 0.008 & 2.562 & 0.130 \\
\hline $12 / 11 / 20142: 00$ & -1.7 & 23.0 & 0.000 & 0.002 & 3.128 & 0.007 & 0.008 & 3.128 & 0.126 \\
\hline $12 / 11 / 20143: 00$ & -1.3 & 23.0 & 0.000 & 0.002 & 3.144 & 0.007 & 0.008 & 3.144 & 0.130 \\
\hline $12 / 11 / 20144: 00$ & -1.9 & 23.0 & 0.000 & 0.002 & 3.147 & 0.007 & 0.008 & 3.147 & 0.126 \\
\hline 12/11/2014 5:00 & -2.8 & 23.0 & 0.000 & 0.002 & 3.186 & 0.007 & 0.008 & 3.186 & 0.123 \\
\hline $12 / 11 / 20146: 00$ & -3.1 & 23.0 & 0.000 & 0.002 & 3.169 & 0.007 & 0.008 & 3.169 & 0.121 \\
\hline
\end{tabular}


Table 53. House C Co-Heat Testing Data

\begin{tabular}{|c|c|c|c|c|c|c|c|c|c|c|}
\hline $\begin{array}{c}\text { Time } \\
\text { Stamp }\end{array}$ & $\begin{array}{c}\text { Outdoor } \\
\text { Temp. }\end{array}$ & $\begin{array}{c}\text { Avg. } \\
\text { Indoor } \\
\text { Temp. }\end{array}$ & $\begin{array}{c}\text { Sensible } \\
\text { Gain } \\
\text { Heater }\end{array}$ & $\begin{array}{c}\text { Sensible } \\
\text { Gain } \\
\text { Heater }\end{array}$ & $\begin{array}{l}\text { Main } \\
\text { Panel }\end{array}$ & $\begin{array}{c}\text { Outdoor } \\
\text { Unit }\end{array}$ & $\begin{array}{c}\text { Air } \\
\text { Hand- } \\
\text { ling } \\
\text { Unit } \\
\text { Fan }\end{array}$ & $\begin{array}{c}\text { Simple } \\
\text { UA } \\
\text { Heat } \\
\text { Loss }\end{array}$ & $\begin{array}{c}\text { Total } \\
\text { Internal } \\
\text { Gain }\end{array}$ & $\begin{array}{l}\text { Calculated } \\
\text { Simple UA }\end{array}$ \\
\hline & $\left({ }^{\circ} \mathrm{C}\right)$ & $\left({ }^{\circ} \mathrm{C}\right)$ & $(\mathrm{kW})$ & $(\mathrm{kW})$ & $(\mathrm{kW})$ & $(\mathrm{kW})$ & $(\mathrm{kW})$ & $(\mathrm{kW})$ & $(\mathrm{kW})$ & $\left(\mathrm{kW} /{ }^{\circ} \mathrm{C}\right)$ \\
\hline $12 / 10 / 20142: 00$ & 3.1 & 23.0 & 0.287 & 0.196 & 2.158 & 0.024 & 0.004 & 2.184 & 2.134 & 0.107 \\
\hline 12/10/2014 3:00 & 3.2 & 23.0 & 0.277 & 0.196 & 2.144 & 0.025 & 0.004 & 2.165 & 2.119 & 0.107 \\
\hline $12 / 10 / 20144: 00$ & 3.2 & 23.0 & 0.267 & 0.196 & 2.128 & 0.024 & 0.004 & 2.171 & 2.104 & 0.106 \\
\hline 12/10/2014 5:00 & 3.2 & 23.0 & 0.264 & 0.200 & 2.147 & 0.022 & 0.004 & 2.171 & 2.125 & 0.107 \\
\hline $12 / 10 / 20146: 00$ & 3.3 & 23.0 & 0.283 & 0.208 & 2.162 & 0.022 & 0.004 & 2.165 & 2.140 & 0.108 \\
\hline 12/11/2014 2:00 & -1.7 & 23.0 & 0.001 & 0.001 & 2.565 & 0.032 & 0.004 & 2.713 & 2.533 & 0.110 \\
\hline 12/11/2014 3:00 & -1.3 & 23.1 & 0.001 & 0.001 & 2.633 & 0.037 & 0.004 & 2.663 & 2.596 & 0.113 \\
\hline $12 / 11 / 20144: 00$ & -1.9 & 23.0 & 0.001 & 0.001 & 2.647 & 0.035 & 0.004 & 2.731 & 2.612 & 0.113 \\
\hline 12/11/2014 5:00 & -2.8 & 23.0 & 0.001 & 0.001 & 2.590 & 0.032 & 0.004 & 2.833 & 2.558 & 0.111 \\
\hline $12 / 11 / 20146: 00$ & -3.1 & 23.0 & 0.001 & 0.001 & 2.624 & 0.030 & 0.004 & 2.867 & 2.594 & 0.113 \\
\hline
\end{tabular}




\section{Appendix H: Impacts of Window Blind Position}

Table 54. Data Used for Multi-Variable Regression-Blinds Closed Period (Sept. 23-29)

\begin{tabular}{|c|c|c|c|c|c|c|c|c|}
\hline & $\begin{array}{c}\text { Avg. } \\
\text { Temp. }\left({ }^{\circ} \mathrm{C}\right)\end{array}$ & $\begin{array}{c}\text { Delta } T \\
\left(\mathbf{T}_{\text {indoor }}-\mathrm{T}\right. \\
\text { outdoor }) \\
\text { House } \mathrm{A} \\
\left({ }^{\circ} \mathrm{C}\right)\end{array}$ & $\begin{array}{c}\text { Delta } T \\
\left(T_{\text {indoor }}-\mathrm{T}\right. \\
\text { outdoor }) \\
\text { House B } \\
\left({ }^{\circ} \mathrm{C}\right)\end{array}$ & $\begin{array}{c}\text { Delta } T \\
\left(T_{\text {indoor }}-\mathrm{T}\right. \\
\text { outdoor }) \\
\text { House C } \\
\left({ }^{\circ} \mathrm{C}\right)\end{array}$ & $\begin{array}{c}\text { Direct } \\
\text { Normal } \\
\text { Radiation } \\
\text { Total } \\
\left(\mathbf{W h} / \mathbf{m}^{2}\right)\end{array}$ & $\begin{array}{c}\text { Total } \\
\text { Cooling } \\
\text { Energy } \\
\text { House A } \\
\text { (kWh) }\end{array}$ & $\begin{array}{c}\text { Total } \\
\text { Cooling } \\
\text { Energy } \\
\text { House B } \\
\text { (kWh) }\end{array}$ & $\begin{array}{c}\text { Total } \\
\text { Cooling } \\
\text { Energy } \\
\text { House C } \\
\text { (kWh) }\end{array}$ \\
\hline Tue. 09/23/14 & 17.30 & -5.9 & -6.9 & -5.1 & $5,895.29$ & 4.03 & 3.37 & 2.63 \\
\hline Wed. 09/24/14 & 18.50 & -5.1 & -6.0 & -4.1 & $5,665.66$ & 4.97 & 4.23 & 3.10 \\
\hline Thu. 09/25/14 & 20.15 & -3.7 & -4.6 & -2.7 & $4,716.51$ & 6.49 & 5.46 & 3.70 \\
\hline Fri. 09/26/14 & 20.17 & -3.8 & -4.6 & -2.6 & $1,619.95$ & 4.76 & 4.57 & 3.40 \\
\hline Sat. 09/27/14 & 19.50 & -4.5 & -5.3 & -3.3 & 864.44 & 3.79 & 3.82 & 2.82 \\
\hline Sun. 09/28/14 & 22.05 & -2.2 & -2.9 & -0.7 & $1,044.04$ & 5.03 & 5.17 & 3.78 \\
\hline Mon. 09/29/14 & 21.10 & -3.3 & -4.0 & -2.1 & $4,535.68$ & 8.29 & 7.08 & 4.73 \\
\hline
\end{tabular}

Table 55. Predicted Cooling Energy Calculation with Normalized Data-Blinds Open Period (Aug. 17-23)

\begin{tabular}{|c|c|c|c|c|c|}
\hline & Avg. Temp. $\left({ }^{\circ} \mathrm{C}\right)$ & $\begin{array}{l}\text { Direct Normal } \\
\text { Radiation Total } \\
\left(\mathbf{W h} / \mathbf{m}^{2}\right)\end{array}$ & $\begin{array}{c}\text { Predicted Total } \\
\text { Cooling Energy } \\
\text { House A- if blinds } \\
\text { were closed } \\
(\mathrm{kWh})\end{array}$ & $\begin{array}{l}\text { Predicted Total } \\
\text { Cooling Energy } \\
\text { House B- blinds } \\
\text { closed period } \\
(\mathrm{kWh})\end{array}$ & $\begin{array}{c}\text { Predicted Total } \\
\text { Cooling Energy } \\
\text { House C } \\
\text { (kWh) }\end{array}$ \\
\hline Sun. 08/17/14 & 24.07 & $1,075.37$ & 8.21 & 7.77 & 5.09 \\
\hline Mon. 08/18/14 & 24.13 & $1,936.92$ & 8.69 & 8.02 & 5.10 \\
\hline Tue. 08/19/14 & 25.99 & $2,874.63$ & 11.57 & 10.28 & 6.39 \\
\hline
\end{tabular}




\begin{tabular}{|c|c|c|c|c|c|}
\hline & Avg. Temp. $\left({ }^{\circ} \mathrm{C}\right)$ & $\begin{array}{c}\text { Direct Normal } \\
\text { Radiation Total } \\
\left(\mathbf{W h} / \mathbf{m}^{2}\right)\end{array}$ & $\begin{array}{l}\text { Predicted Total } \\
\text { Cooling Energy } \\
\text { House A- if blinds } \\
\text { were closed } \\
(\mathrm{kWh})\end{array}$ & $\begin{array}{c}\text { Predicted Total } \\
\text { Cooling Energy } \\
\text { House B- blinds } \\
\text { closed period } \\
(\mathbf{k W h})\end{array}$ & $\begin{array}{c}\text { Predicted Total } \\
\text { Cooling Energy } \\
\text { House C } \\
\text { (kWh) }\end{array}$ \\
\hline Wed. 08/20/14 & 26.91 & $3,969.03$ & 13.25 & 11.52 & 7.04 \\
\hline Thu. 08/21/14 & 26.85 & $3,798.98$ & 13.06 & 11.39 & 6.99 \\
\hline Fri. 08/22/14 & 26.74 & $4,678.43$ & 13.43 & 11.62 & 7.11 \\
\hline \multirow[t]{2}{*}{ Sat. 08/23/14 } & 27.20 & $4,043.29$ & 13.61 & 11.83 & 7.20 \\
\hline & & Total cooling (kWh) & 81.83 & 72.42 & 44.91 \\
\hline
\end{tabular}

Table 56. Window Blinds Regression

\begin{tabular}{|c|c|c|c|c|c|}
\hline SUMMARY OUTP & & & & & \\
\hline Regression Statistic & & & & & \\
\hline R Square & 0.719914 & & & & \\
\hline Adjusted R Square & 0.579871 & & & & \\
\hline Observations & 7 & & & & \\
\hline ANOVA & & & & & \\
\hline & df & SS & MS & $\mathrm{F}$ & $\begin{array}{l}\text { Significance } \\
\mathrm{F}\end{array}$ \\
\hline
\end{tabular}




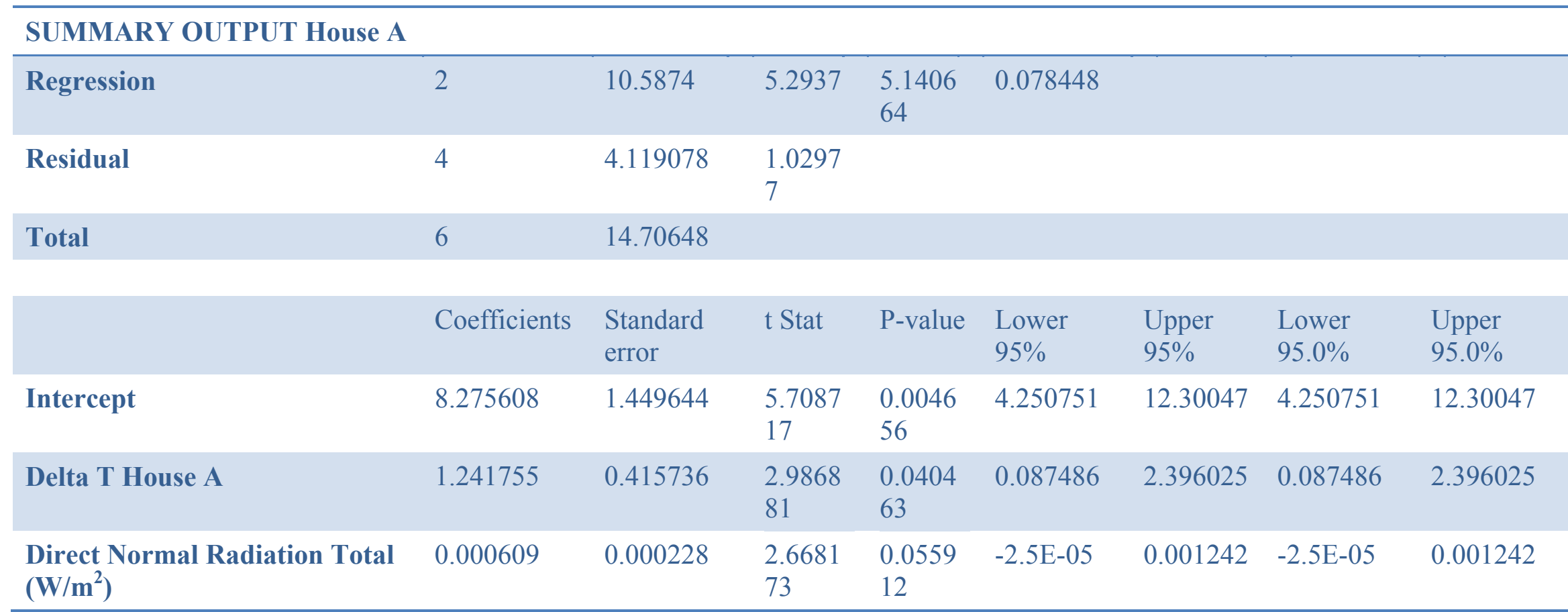

\section{SUMMARY OUTPUT House B}

\section{Regression Statistics}

\begin{tabular}{ll}
\hline Multiple R & $\mathbf{0 . 8 8 7 9 4 6}$ \\
\hline R Square & 0.788448 \\
\hline Adjusted R Square & 0.682672 \\
\hline Standard Error & 0.696203 \\
\hline Observations & 7 \\
\hline
\end{tabular}




\begin{tabular}{|c|c|c|c|c|c|c|c|c|}
\hline \multicolumn{9}{|l|}{ ANOVA } \\
\hline & df & SS & MS & $\mathrm{F}$ & \multicolumn{4}{|l|}{$\begin{array}{l}\text { Significance } \\
\mathrm{F}\end{array}$} \\
\hline \multicolumn{9}{|c|}{ SUMMARY OUTPUT House B } \\
\hline Regression & 2 & 7.225825 & $\begin{array}{l}3.6129 \\
12\end{array}$ & $\begin{array}{l}7.4539 \\
45\end{array}$ & \multicolumn{4}{|l|}{0.044754} \\
\hline Residual & 4 & 1.938792 & $\begin{array}{l}0.4846 \\
98\end{array}$ & & & & & \\
\hline \multirow[t]{2}{*}{ Total } & 6 & 9.164617 & & & & & & \\
\hline & Coefficients & $\begin{array}{l}\text { Standard } \\
\text { error }\end{array}$ & t Stat & P-value & Lower 95\% & $\begin{array}{l}\text { Upper } \\
95 \%\end{array}$ & $\begin{array}{l}\text { Lower } \\
95.0 \%\end{array}$ & $\begin{array}{l}\text { Upper } \\
95.0 \%\end{array}$ \\
\hline Intercept & 8.543596 & 1.113623 & $\begin{array}{l}7.6718 \\
91\end{array}$ & $\begin{array}{l}0.0015 \\
52\end{array}$ & 5.451682 & $\begin{array}{l}11.635 \\
51\end{array}$ & 5.451682 & 11.63551 \\
\hline Delta T House B & 1.025916 & 0.265947 & $\begin{array}{l}3.8575 \\
94\end{array}$ & $\begin{array}{l}0.0181 \\
84\end{array}$ & 0.287528 & $\begin{array}{l}1.7643 \\
03\end{array}$ & 0.287528 & 1.764303 \\
\hline $\begin{array}{l}\text { Direct Normal Radiation } \\
\text { Total }\left(\mathbf{W} / \mathbf{m}^{2}\right)\end{array}$ & 0.000376 & 0.000158 & $\begin{array}{l}2.3841 \\
63\end{array}$ & $\begin{array}{l}0.0756 \\
46\end{array}$ & $-6.2 \mathrm{E}-05$ & $\begin{array}{l}0.0008 \\
15\end{array}$ & $-6.2 \mathrm{E}-05$ & 0.000815 \\
\hline \multicolumn{9}{|c|}{ SUMMARY OUTPUT House C } \\
\hline \multicolumn{9}{|l|}{ Regression Statistics } \\
\hline Multiple R & 0.893938 & & & & & & & \\
\hline R Square & 0.799126 & & & & & & & \\
\hline Adjusted R Square & 0.698688 & & & & & & & \\
\hline
\end{tabular}




\begin{tabular}{|c|c|c|c|c|c|c|c|c|}
\hline Standard Error & 0.388353 & & & & & & & \\
\hline Observations & 7 & & & & & & & \\
\hline \multicolumn{9}{|c|}{ SUMMARY OUTPUT House C } \\
\hline \multicolumn{9}{|l|}{ ANOVA } \\
\hline & df & SS & MS & $\mathrm{F}$ & $\begin{array}{l}\text { Significance } \\
\text { F }\end{array}$ & & & \\
\hline Regression & 2 & 2.399962 & $\begin{array}{l}1.1999 \\
81\end{array}$ & $\begin{array}{l}7.9564 \\
67\end{array}$ & 0.040351 & & & \\
\hline Residual & 4 & 0.603273 & $\begin{array}{l}0.1508 \\
18\end{array}$ & & & & & \\
\hline \multirow[t]{2}{*}{ Total } & 6 & 3.003236 & & & & & & \\
\hline & Coefficients & $\begin{array}{l}\text { Standard } \\
\text { error }\end{array}$ & t Stat & P-value & Lower 95\% & $\begin{array}{l}\text { Upper } \\
95 \%\end{array}$ & $\begin{array}{l}\text { Lower } \\
95.0 \%\end{array}$ & $\begin{array}{l}\text { Upper } \\
95.0 \%\end{array}$ \\
\hline Intercept & 4.386133 & 0.369196 & $\begin{array}{l}11.880 \\
24\end{array}$ & $\begin{array}{l}0.0002 \\
87\end{array}$ & 3.361082 & $\begin{array}{l}5.4111 \\
85\end{array}$ & 3.361082 & 5.411185 \\
\hline Delta T House C & 0.577592 & 0.144814 & $\begin{array}{l}3.9885 \\
12\end{array}$ & $\begin{array}{l}0.0162 \\
85\end{array}$ & 0.175524 & $\begin{array}{l}0.9796 \\
59\end{array}$ & 0.175524 & 0.979659 \\
\hline $\begin{array}{l}\text { Direct Normal Radiation } \\
\text { Total }\left(\mathbf{W} / \mathbf{m}^{2}\right)\end{array}$ & 0.00022 & $9.1 \mathrm{E}-05$ & $\begin{array}{l}2.4132 \\
45\end{array}$ & $\begin{array}{l}0.0732 \\
97\end{array}$ & $-3.3 \mathrm{E}-05$ & $\begin{array}{l}0.0004 \\
72\end{array}$ & $-3.3 \mathrm{E}-05$ & 0.000472 \\
\hline
\end{tabular}




\section{Appendix I: Impacts of Controlled Heater Energy}

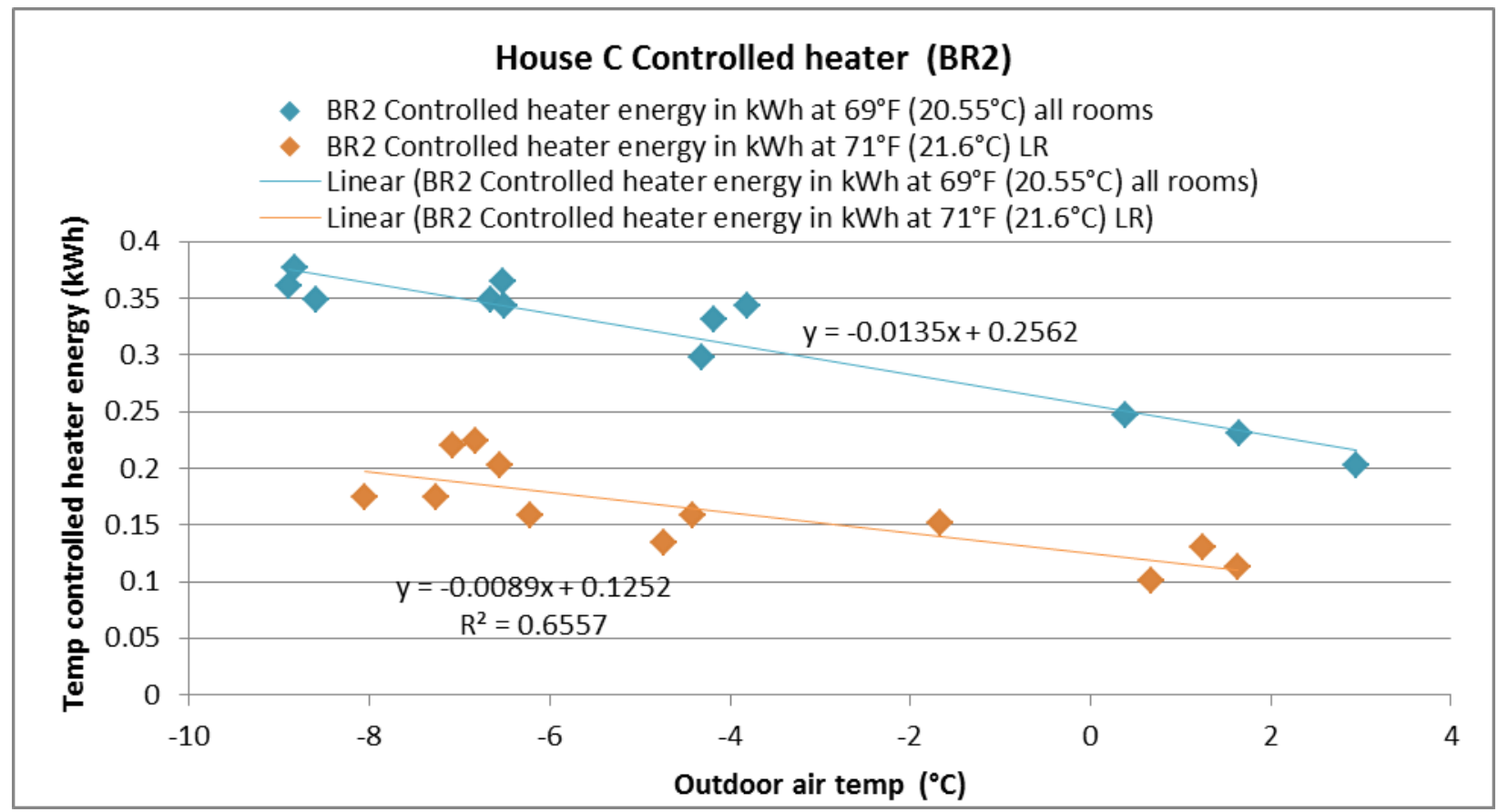

Figure 83. House C Bedroom 2 impacts of controlled heater energy 


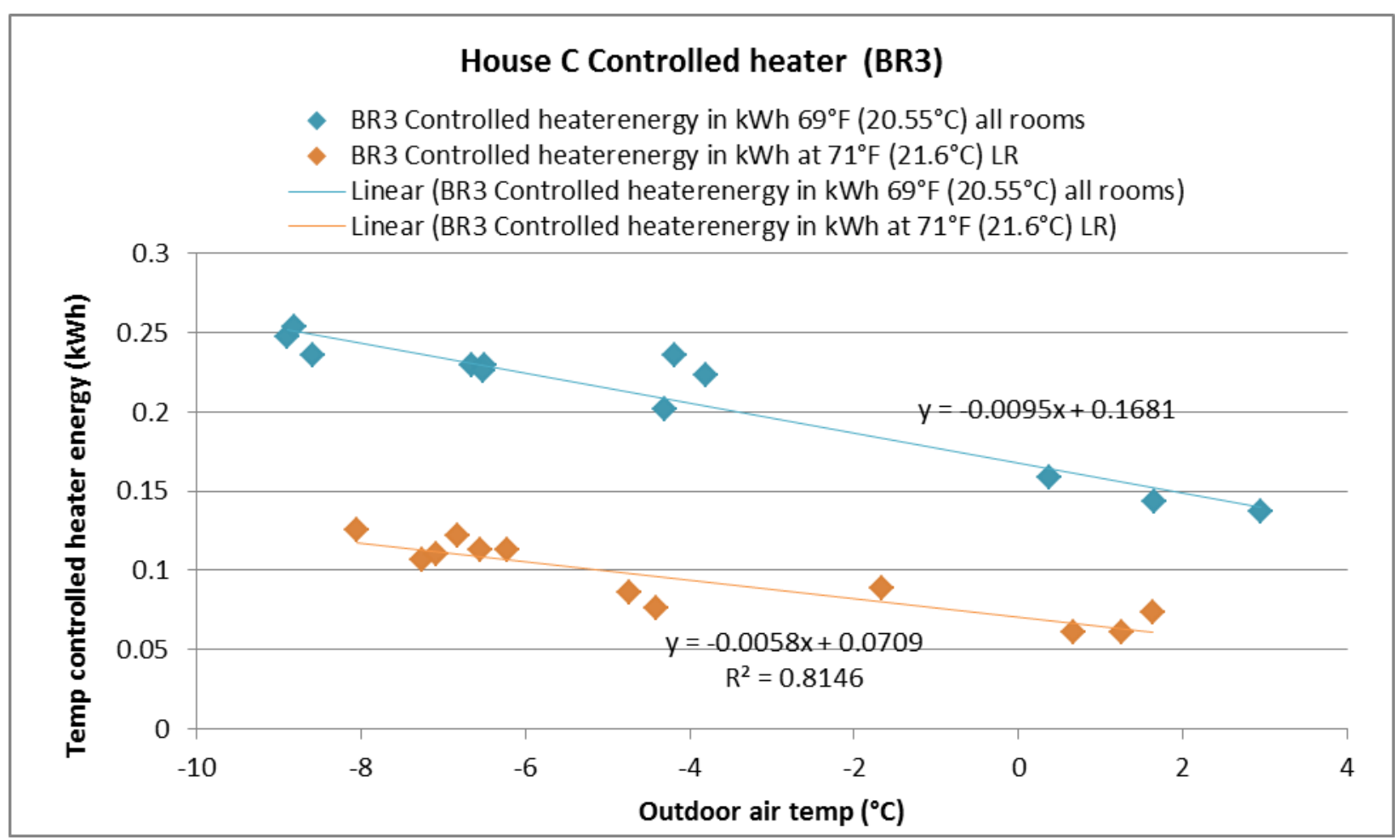

Figure 84. House C Bedroom 3 of controlled heater energy 


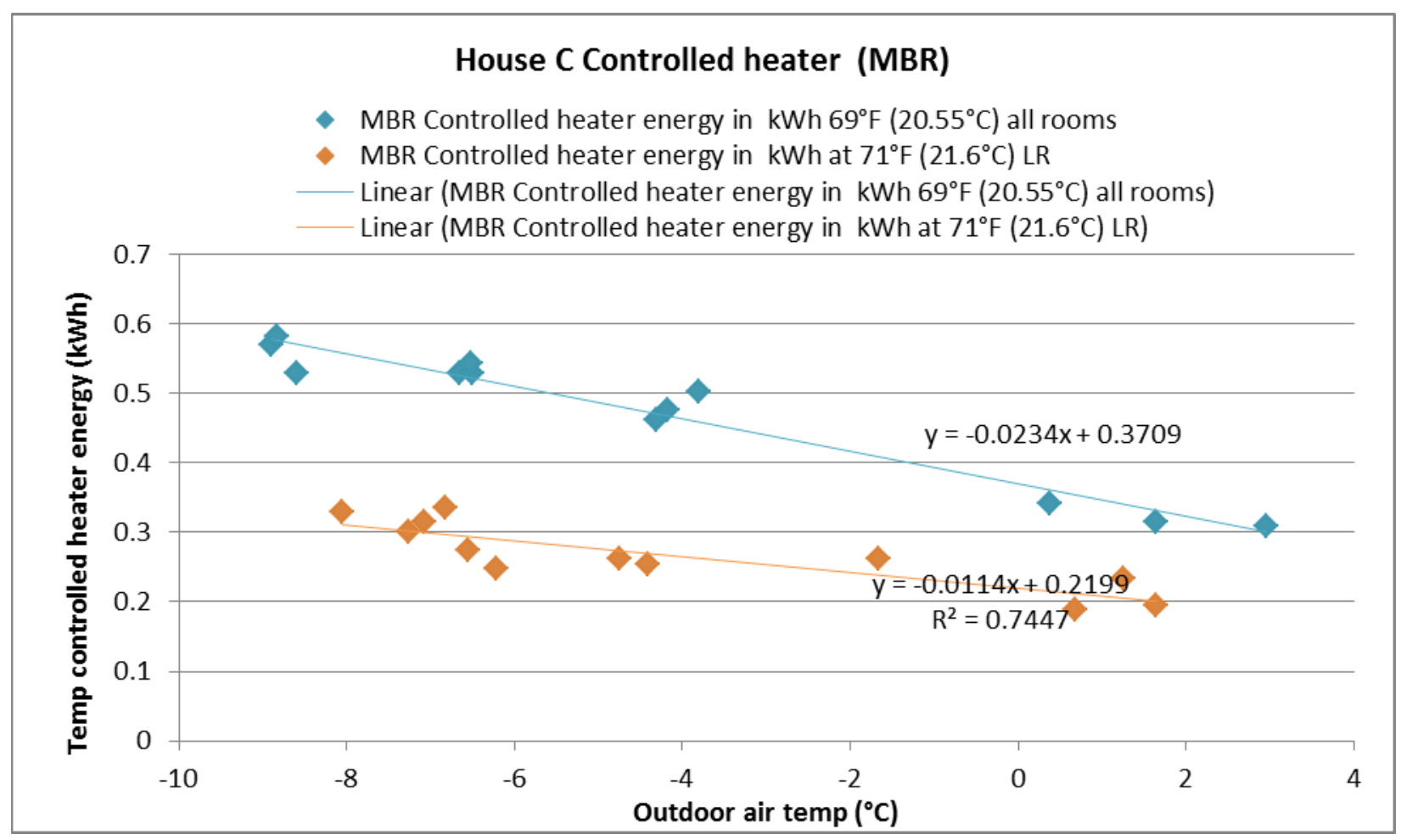

Figure 85. House C master bedroom impacts of controlled heater energy

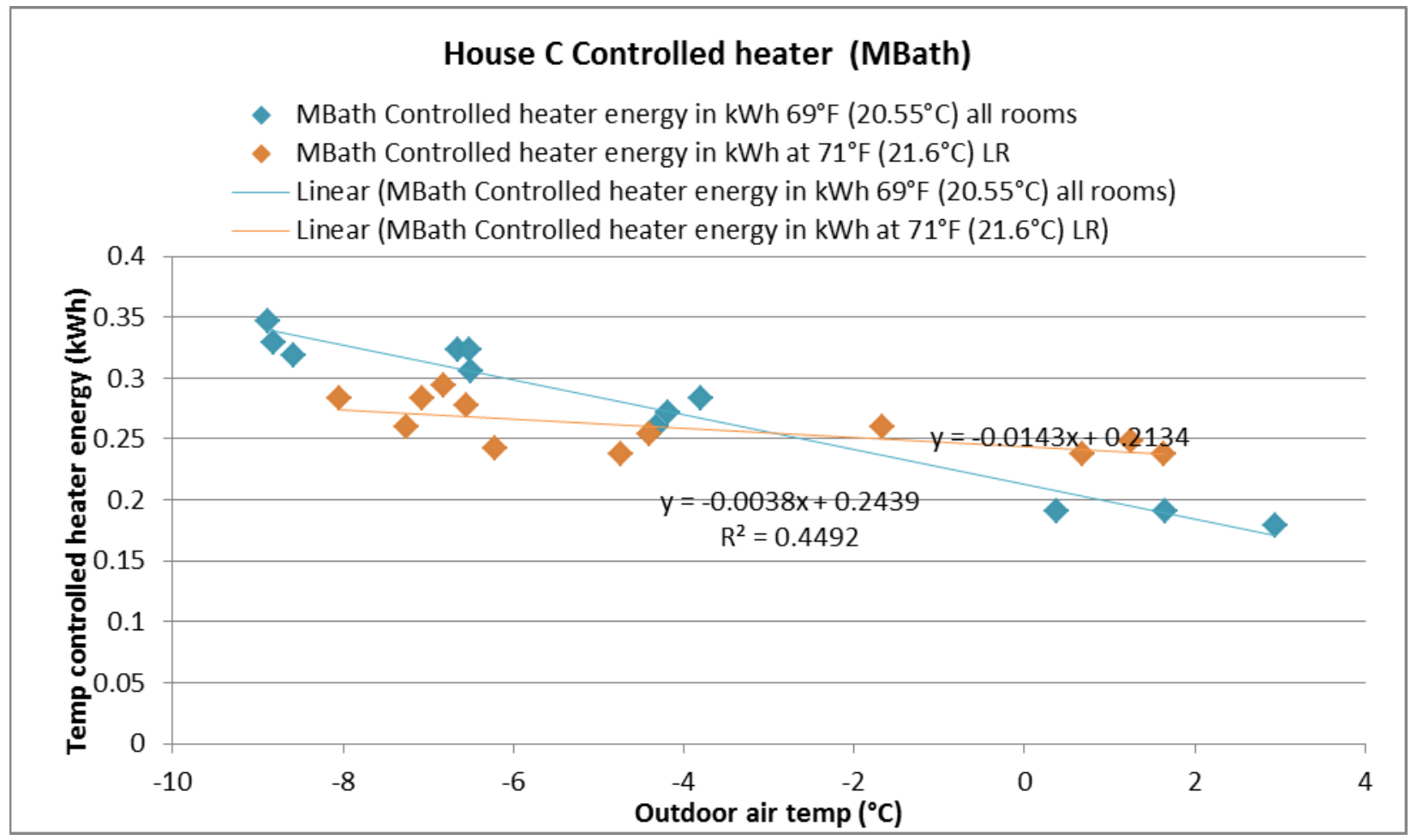

Figure 86. House $\mathbf{C}$ master bathroom impacts of controlled heater energy 


\section{Appendix J: Construction Drawings}

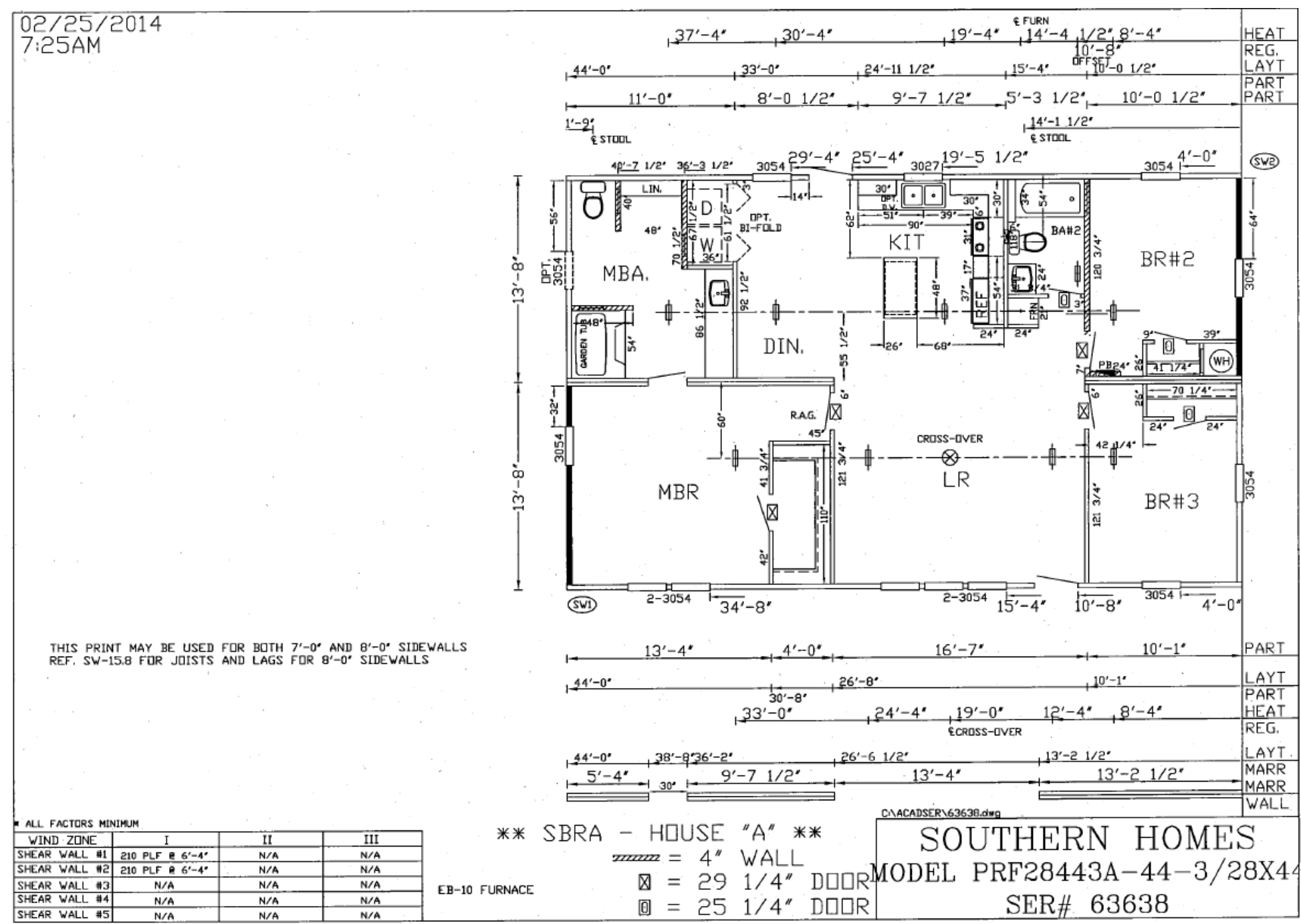

Figure 87. House A production print (House B is identical.) 


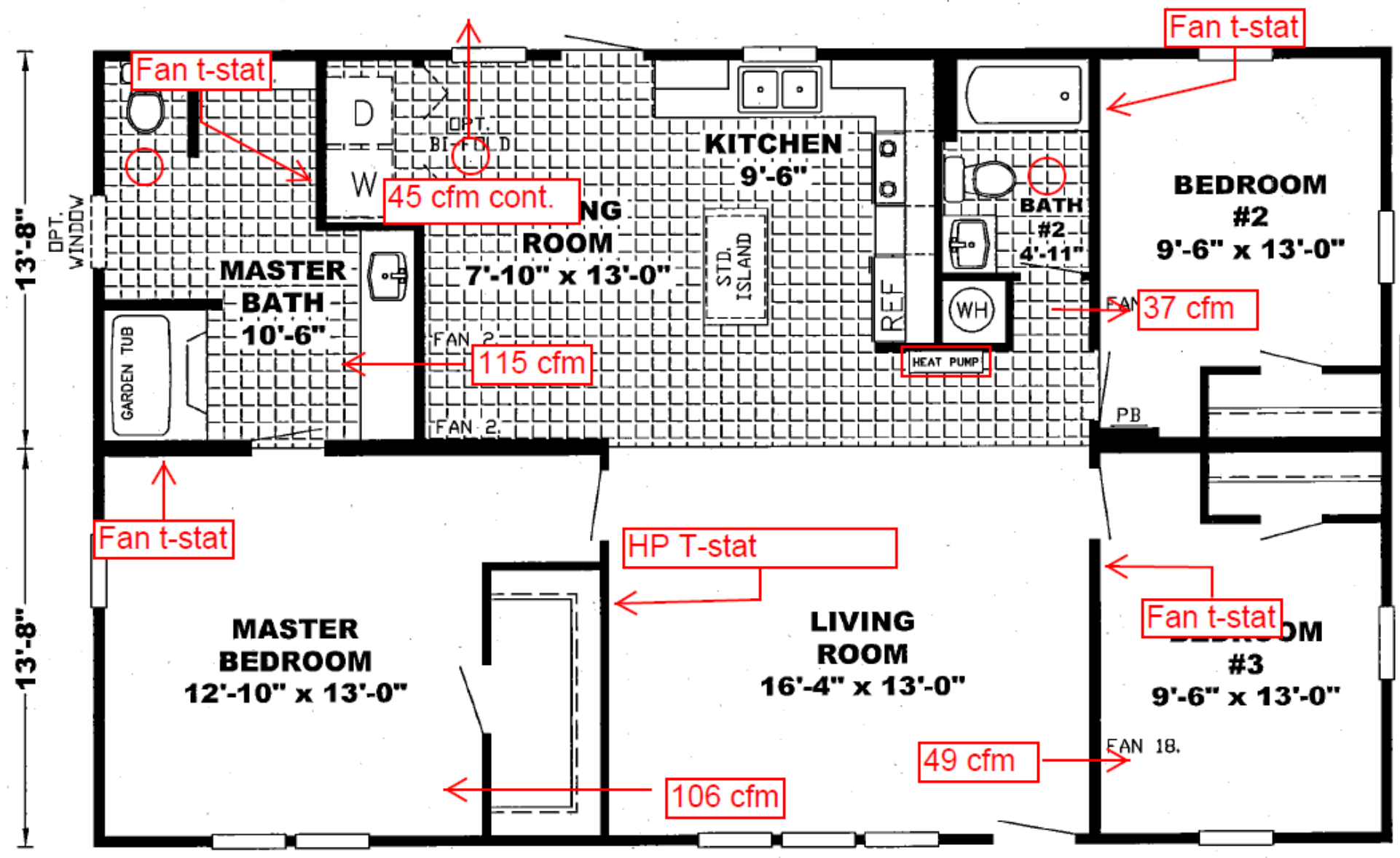

Figure 88. House $\mathrm{C}$ mechanical system schematic plan 


\section{Wall and Roof Insulation Details (House C)}

Figure 89 through Figure 93 show construction details indicating how the exterior continuous insulation was incorporated into the wall assembly.

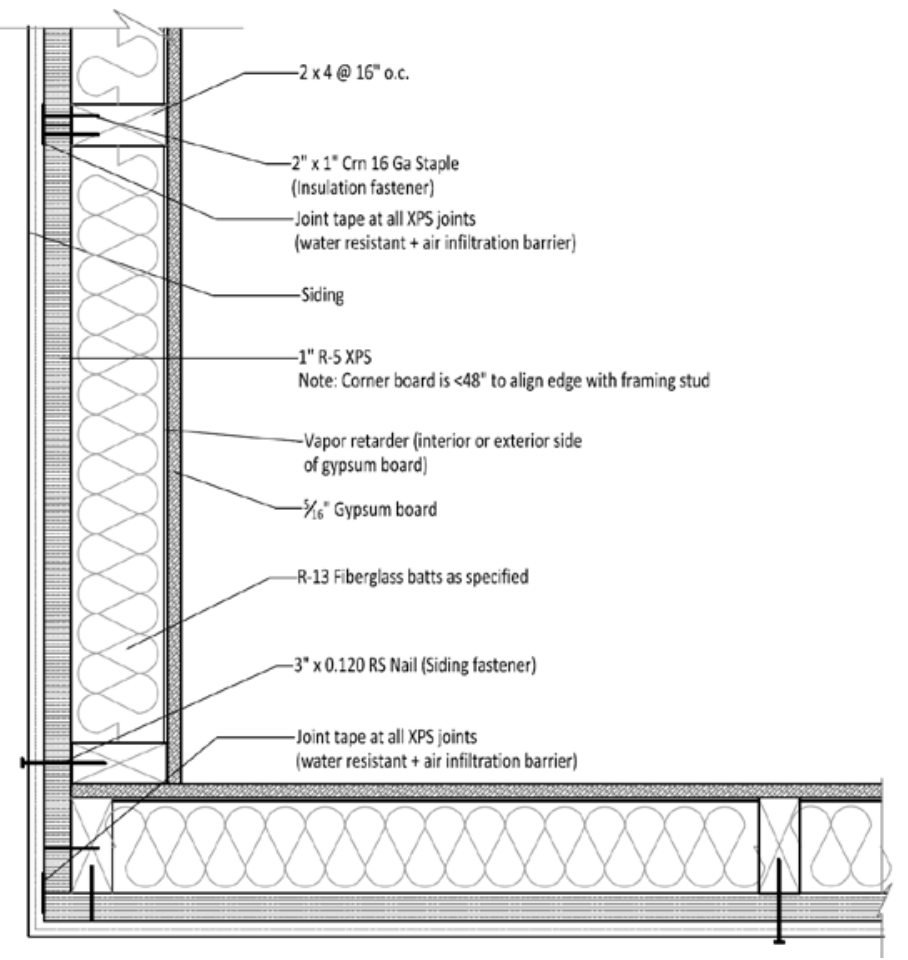

Figure 89. Plan view of wall

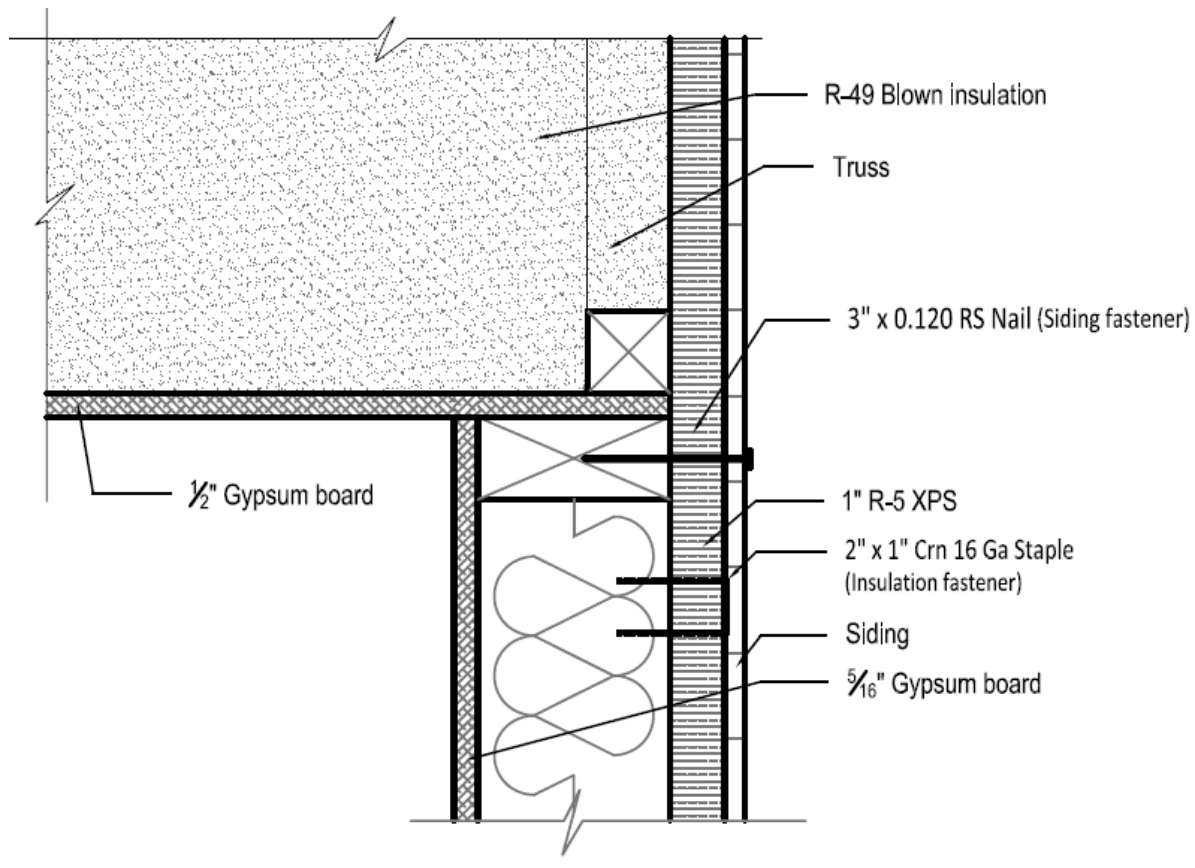

Figure 90. Top plate (gable wall section) 


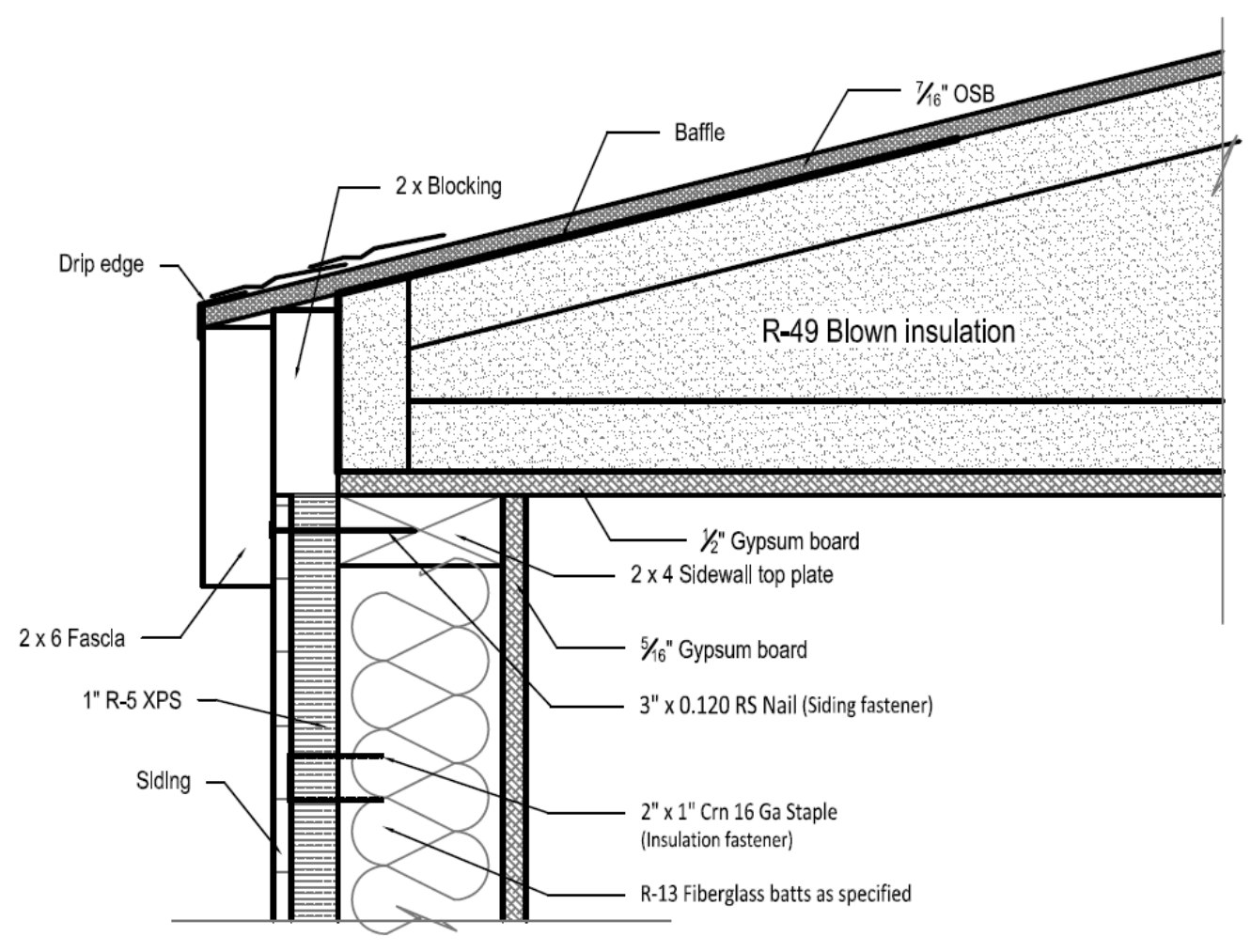

Figure 91. Roof-to-wall connection (side wall section)

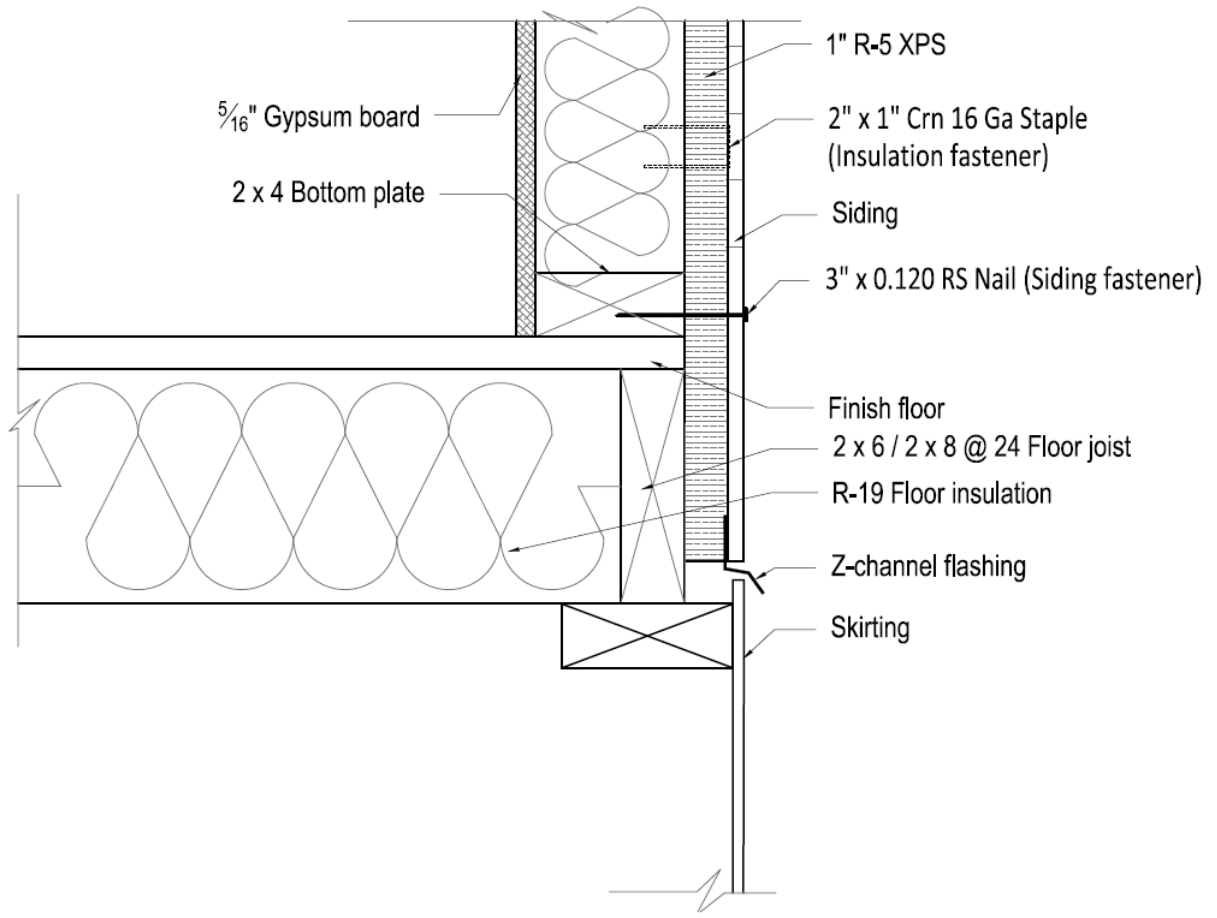

Figure 92. Floor-to-wall connection (side wall section) 


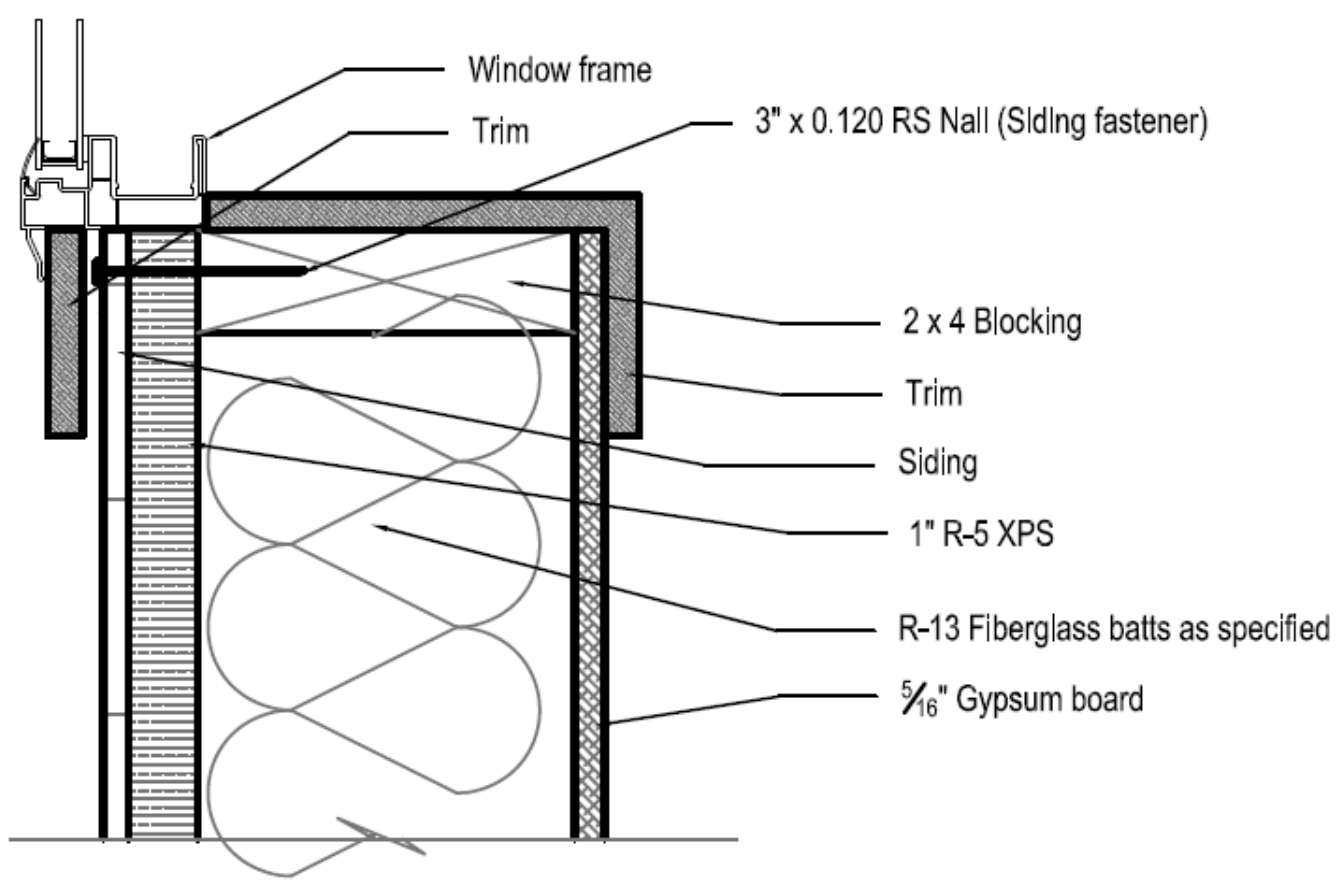

Figure 93. Window sill 


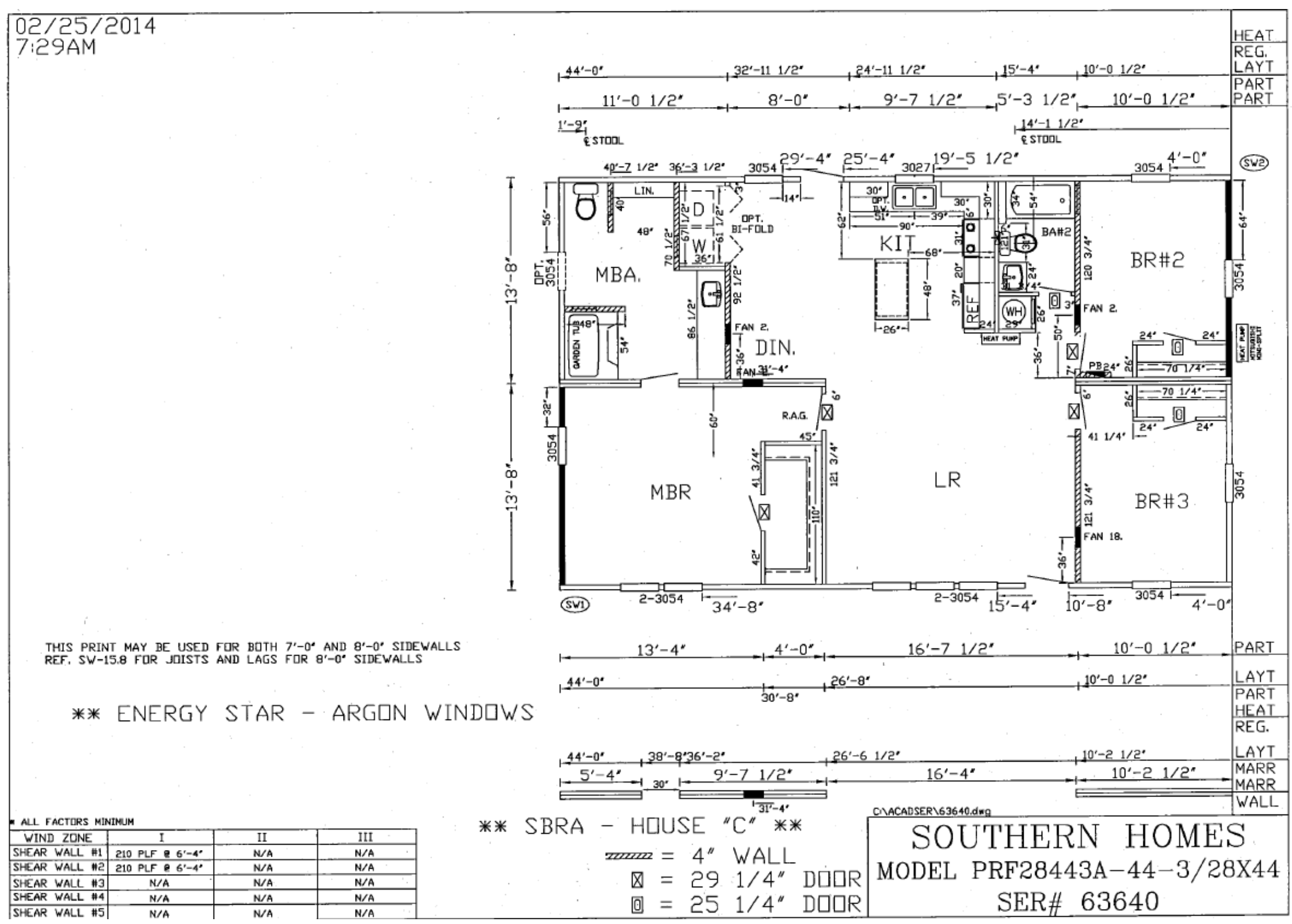

Figure 94. House $\mathrm{C}$ production print 
